University of Nebraska - Lincoln

DigitalCommons@University of Nebraska - Lincoln

$1-14-2020$

\title{
The preColumbian Textiles in the Roemer- and Pelizaeus-Museum Hildesheim, Germany
}

Lena Bjerregaard

University of Copenhagen, bjerregaardlena@aol.com

Follow this and additional works at: https://digitalcommons.unl.edu/zeabook

Part of the Fiber, Textile, and Weaving Arts Commons, Indigenous Studies Commons, Museum Studies Commons, and the Other History of Art, Architecture, and Archaeology Commons

\section{Recommended Citation}

Bjerregaard, Lena, "The preColumbian Textiles in the Roemer- and Pelizaeus-Museum Hildesheim, Germany" (2020). Zea E-Books. 84.

https://digitalcommons.unl.edu/zeabook/84

This Book is brought to you for free and open access by the Zea E-Books at DigitalCommons@University of Nebraska - Lincoln. It has been accepted for inclusion in Zea E-Books by an authorized administrator of DigitalCommons@University of Nebraska - Lincoln. 


\section{The preColumbian Textiles}

in the Roemer- and

\section{Pelizaeus-Museum}

\section{Hildesheim,}

\section{Germany}

Lena Bjerregaard

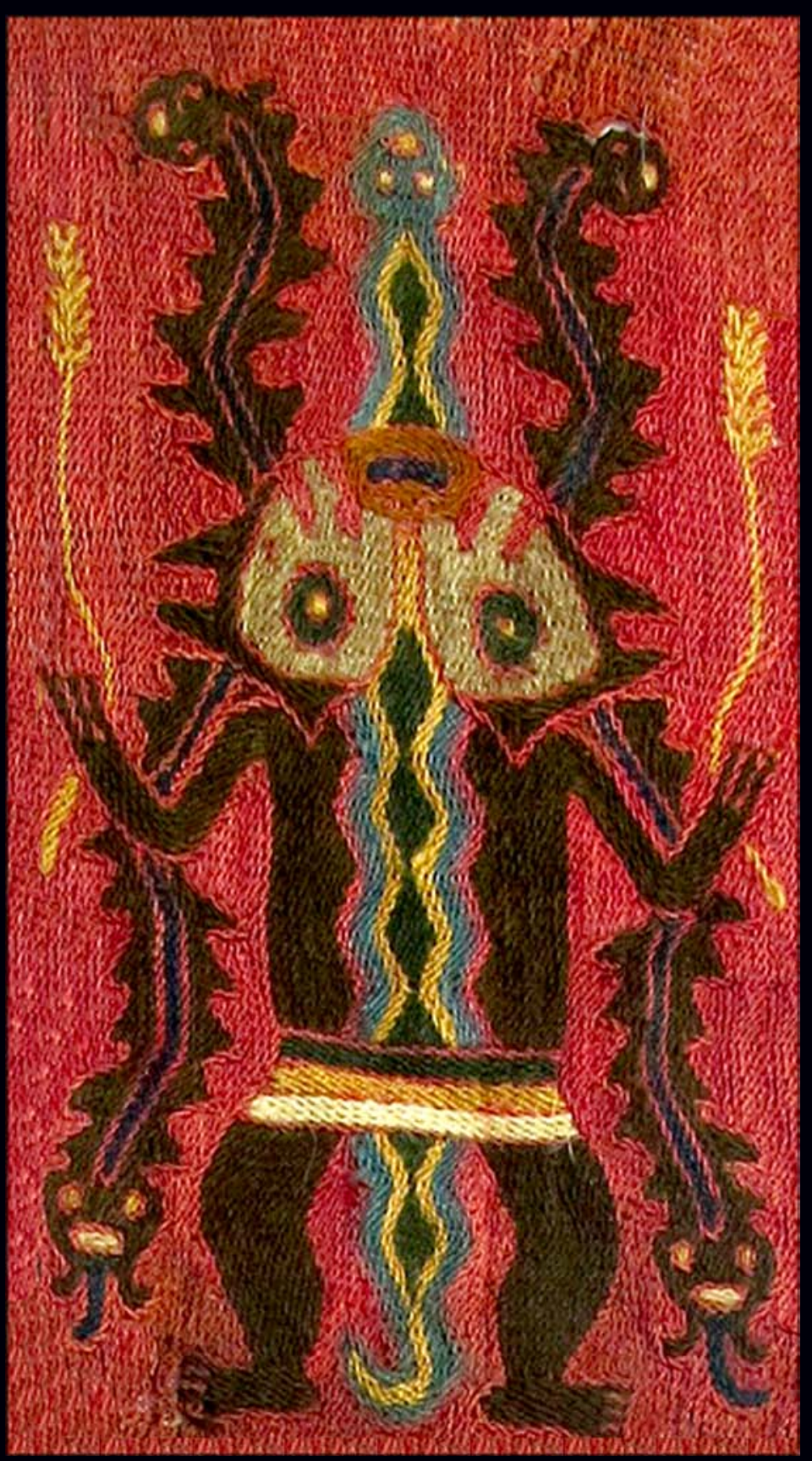


Along the coast of Peru is one of the driest deserts in the world. Here, under the sand, the ancient Peruvians buried their dead wrapped in gorgeous textiles. As organic material keeps almost forever when stored without humidity, light and oxygen, many of the mummies excavated in the last hundred years are in excellent conditions. And so are the textiles wrapped around them. Their clear colors are still dazzling and the textile fibers in good condition.

Textiles were highly valued objects in ancient Peru - used for expressing status and diverse messages in these non-literate but highly organized and very developed cultures. Much energy, innovation and aesthetic sensibility were invested in the textiles.

The preColumbian peoples had access to exquisite materials: the local fibers were camelid fibers (alpaca and vicuña), cotton and plant fibers (agave, for instance). The camelid fibers have very little scales compared to sheep fibers, and are long, soft and lustrous. The Peruvian cotton grew in 5 different colors.

The ancient Peruvians were also master dyers and have for thousands of years dyed their yarn with indigo blue, madder red, cochineal red, sea snail purple and yellow from many kinds of plants. And so they produced some of the finest, most beautiful and most interesting textiles in the world. Instead of writing, they kept the order in their world encoded in textile fibers.

The Roemer- and Pelizaeus-Museum in Hildesheim houses a collection of 405 preColumbian textiles. Most of them are fragments, but a few complete pieces are present. I have chosen 133 pieces for this publication, to represent the collection at its best.

Cover: Digital reconstruction based on Paracas/Nazca edge band, Zarnitz Collection.

Zea Books

Lincoln, Nebraska

ISBN 978-1-60962-166-7

doi 10.32873/unl.dc.zea.1098 


\section{The preColumbian Textiles in the Roemer- and Pelizaeus-Museum Hildesheim, Germany}

Lena Bjerregaard

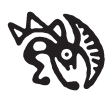

Zea Books

Lincoln, Nebraska 2020 


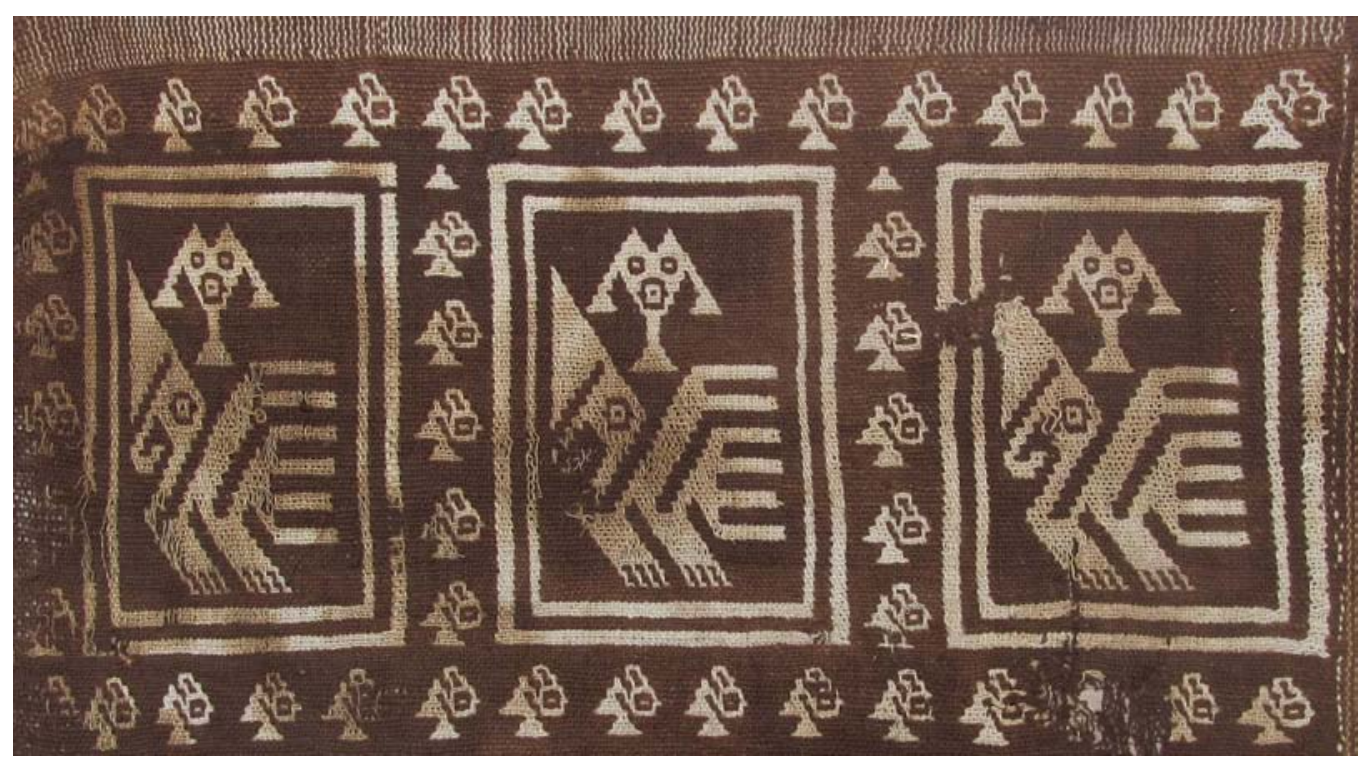

Copyright $\odot 2020$ Lena Bjerregaard All rights reserved.

ISBN 978-1-60962-166-7

doi 10.32873/unl.dc.zea.1098

Set in Myriad types.

Zea Books are published by the University of Nebraska-Lincoln Libraries

Electronic (pdf) ebook edition available online at https://digitalcommons.unl.edu/zeabook/

Print edition available from http://www.lulu.com/spotlight/unllib

UNL does not discriminate based upon any protected status.

Please go to http://www.unl.edu/equity/notice-nondiscrimination
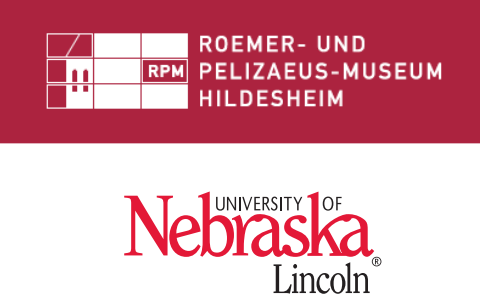


\section{Contents}

Foreword by Andrea Nicklisch and Regine Schulz . . . . . . 5

Introduction by Lena Bjerregaard . . . . . . . . . . . . 7

The Roemer- and Pelizaeus-Museum's preColumbian textile collection . . . . . . . . . . . . . . . . . 8

Determination of styles . . . . . . . . . . . . . . . . . . 9

A brief description of the preColumbian textiles over the last 3000 years . . . . . . . . . . . . . . . . . . . 11

Some indications to help identify a preColumbian textile . . . 12

Explanation of terms in textile analysis . . . . . . . . . 14

Bibliography. . . . . . . . . . . 15

Catalogue of preColumbian Textiles in the Roemer- and Pelizaeus-Museum Hildesheim, Germany

Paracas/Nazca - 500 BC - 500 AD . . . . . . . . . . . . 19

Middle Horizon -400-800 AD . . . . . . . . . . . . . . 22

Lambayeque -900-1300 AD . . . . . . . . . . . . . 27

Late Intermediate Period - $1200-1450$ AD . . . . . . . 37

Inka-1400-1550 AD . . . . . . . . . . . . . . . .994

Colonial $-1600-1700 \mathrm{AD}$. . . . . . . . . . . . . 103

Recent -1800-2000 AD . . . . . . . . . . . . . . 104

Problematic Objects. . . . . . . . . . . . . . . . 106 



\title{
Foreword
}

\author{
Andrea Nicklisch and Regine Schulz
}

The Roemer- und Pelizaeus-Museum combines two originally separate museums under a single roof: the Roemer-Museum, founded in 1844, and the Pelizaeus Museum which opened its doors in 1911. While the collections of the Pelizaeus-Museum are mainly composed of ancient Egyptian and Graeco-Roman items, the comprehensive holdings of the Roemer-Museum (ca. 310,000 objects) are more multi-faceted. They comprise not only the history of the city and region of Hildesheim but also ethnological and art historical objects as well as natural specimens from all over the world. The founders of the "twin museums", Hermann Roemer and Wilhelm Pelizaeus, intended to create a "World Museum" that covered very diverse aspects of nature and culture. As a result, the collections of the Roemer-Museum reflect - among other things - the world outside Europe. The first annual report of the Hildesheim museum society (1845) listed the "ethnographic collection", which was then part of the art section, as having no more than 28 objects. However, this part of the collection was to grow considerably in the decades that followed and includes today ca. 14,000 objects from all continents.

The pre-Hispanic collection from the South American Andes is one of the highlights of the Roemer-Museum's ethnographic department. It consists mainly of pottery of various pre-Columbian Andean cultures but also includes jewellery, wooden objects, and textiles. In 1905 the new director of the Roemer Museum, Rudolph Hauthal, wrote that he wanted the pre-Hispanic Andean collection of the Roemer-Museum to rank among the best not only in Germany, but ideally also in all of Europe. The first exhibition of that collection was opened in 1906.

The $175^{\text {th }}$ anniversary of the Roemer-Museum in 2019 is a perfect occasion for publishing a selection of important pieces from the Andean pre-Hispanic textiles collection. The museum was thus delighted when Lena Bjerregaard, an internationally renowned expert on pre-Columbian textiles, agreed to examine that group of textiles and to identify the provenance of the individual specimens. This will enable an international public to gain knowledge about this collection, which was as yet largely unpublished. In addition, Lena Bjerregaard's study shows the connections between collectors and collections in German museums in the late $19^{\text {th }}$ and early $20^{\text {th }}$ century. 


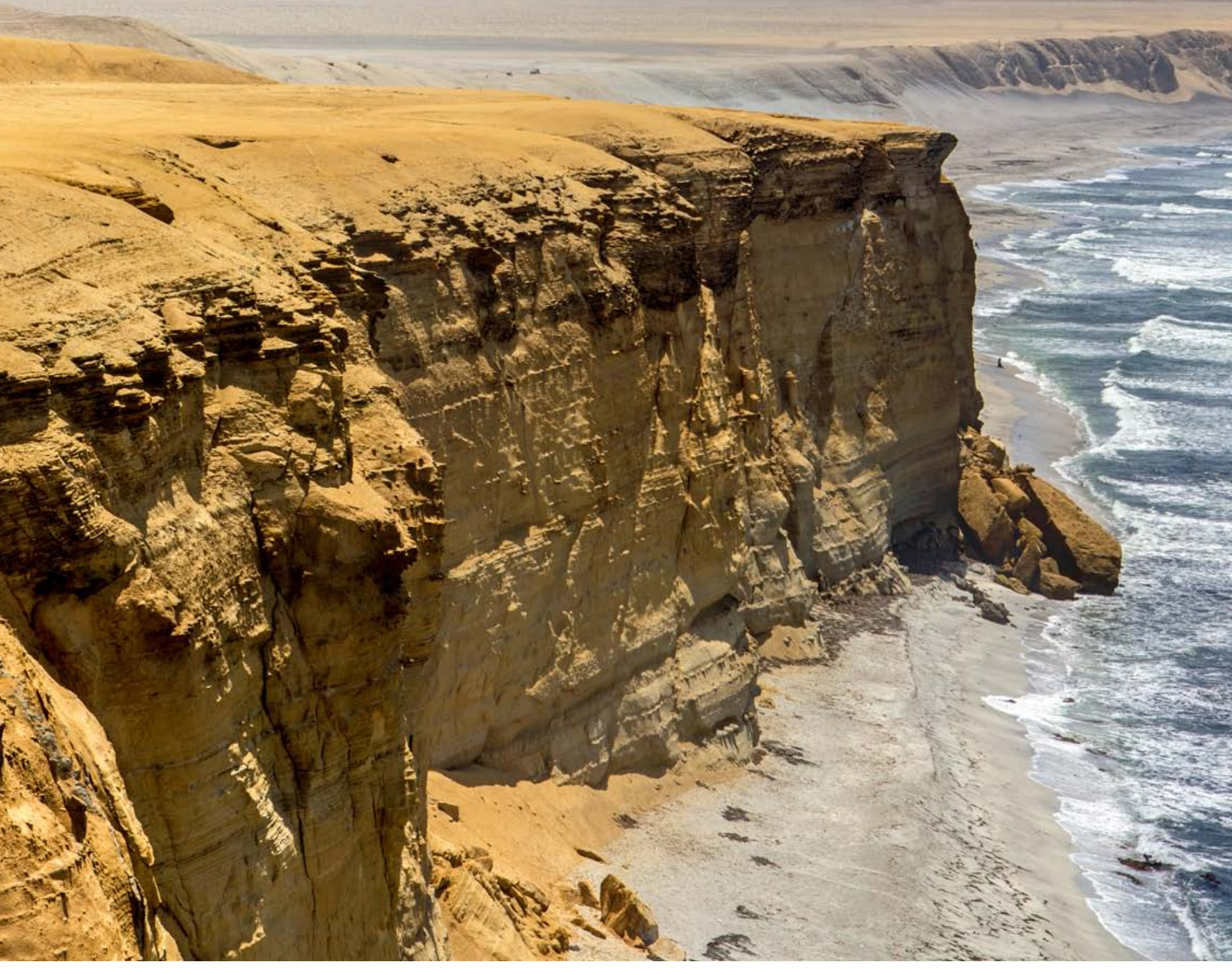




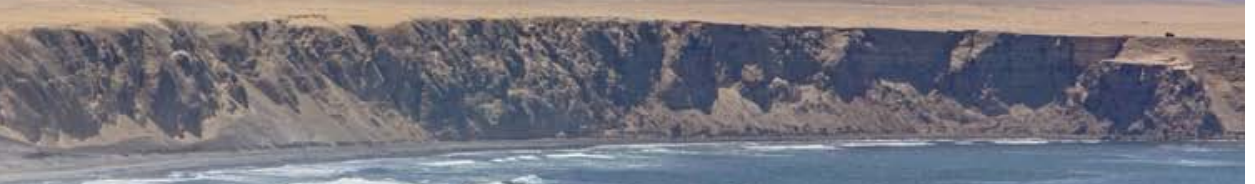

\section{Introduction}

Along the coast of Peru is one of the driest deserts in the world. Here, under the sand, the ancient Peruvians buried their dead wrapped in gorgeous textiles. As organic material keeps almost forever when stored without humidity, light and oxygen, many of the mummies excavated in the last hundred years are in excellent conditions. And so are the textiles wrapped around them. Their clear colors are still dazzling and the textile fibers in good condition.

Textiles were highly valued objects in ancient Peru - used for expressing status and diverse messages in these non-literate but highly organized and very developed cultures. Much energy, innovation and aesthetic sensibility were invested in the textiles.

The preColumbian peoples had access to exquisite materials: the local fibers were camelid fibers (alpaca and vicuña), cotton and plant fibers (agave, for instance). The camelid fibers have very little scales compared to sheep fibers, and are long, soft and lustrous. The Peruvian cotton grew in 5 different colors.

The ancient Peruvians were also master dyers and have for thousands of years dyed their yarn with indigo blue, madder red, cochineal red, sea snail purple and yellow from many kinds of plants. And so they produced some of the finest, most beautiful and most interesting textiles in the world.

Instead of writing, they kept the order in their world encoded in textile fibers. 

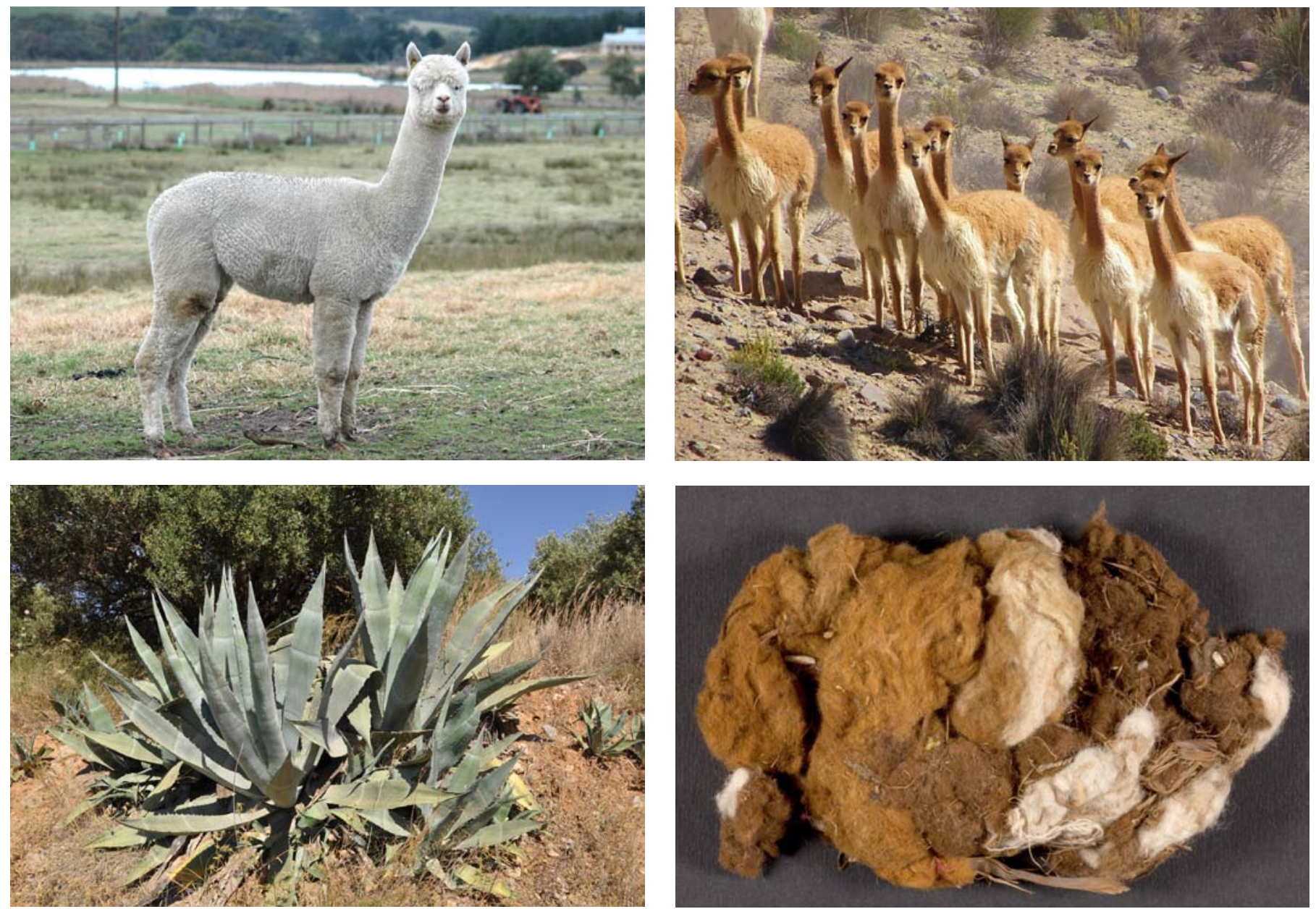

\section{The Roemer- and Pelizaeus-Museum's preColumbian textile collection}

The Roemer- and Pelizaeus-Museum in Hildesheim houses a collection of 405 preColumbian textiles. Most of them are fragments, but a few complete pieces are present.

I have chosen 133 pieces for this publication, to represent the collection at its best.

Almost all the textiles have no information on either the collector or the donor and also have no geographic provenience. Some of them are very, very similar to other fragments (very likely from the same textile) in the collection that Wilhelm Gretzer sold to the now Ethnological Museum in Berlin in 1899 and 1907 and could have been from his collection. Gretzer was a close friend of the then director of the Roemer Museum, Prof. Rudolf Hauthal, and at the time it was a common practice both for collectors and museums to cut up the ancient archaeological textiles and sell or give them away as

Photos

Previous pages: Paracas National Reserve, Peru (masT3rOD, Wikimedia, CC-BY)

Above, clockwise from top left:

Alpaca (Notnoisy at Wikimedia, CC-BY); Group of vicuñas in Peru (Marshallhenrie, Wikimedia, CC-BY-SA); Peruvian brown cotton (Cornell University Anthropology Collections, 899.1.8.); Agave deserti in Palm Canyon, California (Stan Shebs, CC-BY-SA). 
"design samples" or as it was called in Germany "Doubletten". This custom has scattered fragments of archaeological textiles in many museums and collections worldwide, and recently researchers have begun to register and at least digitally reunite these fragments in order to reconstruct the form of a complete piece.

The museum's collection has samples from many different places and cultures - from 2000 years ago and up into recent times. There are one Paracas/Nazca (500 BC-500 AD), 4 Middle Horizon (400-800 AD) pieces, 15 Lambayeque (900-1100 AD), 11 Inka (1450-1550 AD), 1 colonial (1550-1800 $A D)$ and 2 fine objects from 1800-1900 AD. There is even a falsified object - a feathered shield put together partly from preColumbian feathered strings, but in an improper way.

All the rest (about 370 pieces) are from the Late Intermediate Period (11001450 AD). These textiles can largely be defined geographically as north-, central- or south coast textiles. However, there was much trade, inspiration and subcultures involved - and it is often very difficult to say exactly where a textile was found, or made. I have tried my best - with a little help from my friends.

Wilhelm Gretzer mostly delivered his textiles to the museums with stated provenience - and most of them came from Pachacamac on the central coast. Pachacamac was, however, a ritual place in use over thousands of years and by many different cultures. For this reason, often textiles in north and south coast styles have Pachacamac as provenience in the museum collections he furnished. In the late intermediate period (12-1450 AD) various cultures coexisted - on the central coast the Ychsma and Chancay cultures have only quite recently been defined by researchers, and also on the north coast different cultures were competing side by side during that period.

\section{Determination of styles}

In order to determine the style of a preColumbian textile without provenience many different parameters are used.

The iconography of the textile is considered. And then the materials and the techniques that differed from culture to culture.

\section{Materials:}

The fibers used to create textiles in ancient Peru were camelid hair, cotton and other plant fibers. The highland cultures (Wari/Tiwanaku, Inka) had easier access to camelid fibers, as most camelids lived in the highlands. Each of these cultures at their time dominated large areas of Peru/ Bolivia/ Chile/ 
Ecuador and spread their artistic influence from north to south and from the Andes to the coast. The coastal cultures like Moche, Lambayeque and Chimu in the north and Ychsma and Chancay on the central coast were not so geographically widespread. They were cotton growers, and used camelid fibers more sparingly as added decoration on cotton fabrics.

Plant fibers were much used on the coast during the late intermediate period. For instance, the many central coast hairnets were made in Fourcraea andina - a South American agave.

\section{Techniques:}

The spinning/plying techniques differed in ancient Peru and can provide information on the culture/style.

Cotton was mostly spun locally - a sign of this is that within the different cultures mostly the spinning and plying direction were the same, but differed from culture to culture. Cotton fibers were/are spun holding the spindle vertically resting it in a bowl. Often the seeds are extracted while spinning. Cotton yarns were either $\mathrm{S}$ or $\mathrm{Z}$ spun, $\mathrm{S}$ or $\mathrm{Z}$ plied and could be used un-plied, either single or paired.

Spinning and plying camelid fibers was/is done vertically on a drop spindle. Cotton fibers are spun horizontally with the tip of the spindle normally resting in a bowl/gourd.

Almost everywhere throughout the Andean world, camelid fiber yarns were two Z-spun yarns plied together in the $\mathrm{S}$ direction. They were often probably imported to the coast from the Andes already spun and plied.

Cotton yarns diverged from culture to culture much more in the direction of spinning/plying.

The weaving and other non-woven techniques were many - as a matter of fact preColumbian artisans used practically all the techniques known in Europe before the industrialisation - and a few more very complicated techniques unknown in Europe (such as discontinuous warp and weft).

Most textiles were woven on the backstrap loom - the first loom everywhere in the world. It consists basically of 2 sticks between which the warp is mounted. The top stick is tied with a rope to some stable pole/poles and the bottom stick is attached around the weaver's hips. She/he then controls the tension of the warp by her body movements. Two or more sheds are then inserted in the warp - most textiles in ancient Peru were plain weave (warp-faced or balanced, gauze weave, double weave) but also complicated warp patterns and twill were woven on the backstrap loom. On a backstrap loom every technique can be made. The length of the warp is unlimited, but the width of the fabrics cannot be more than ca $80 \mathrm{~cm}$ - the span that one weaver can manage. Larger textiles were created by sewing together several woven panels. 
At least two cultures - Wari/Tiwanaku and Inka - also used a large twobeam loom. On that they wove their large tunics in tapestry and the women's very large wrap-around dresses. This loom can produce very wide textiles and several weavers can work side by side on the same textile. A tunic was woven sideways - so the tunic had the warp horizontal when worn.

The non-woven techniques are more time-consuming than weaving and usually used for smaller objects, such as headdress elements. They were created with few tools, such as a needle or awl. With endless variations of braiding, plaiting, looping and knotting the preColumbian people created bands, slings, lace-like trimmings and hairnets.

The looping techniques used in Europe were mainly used for coarse mittens and hats, but in Peru (Paracas/Nazca especially) this technique was immensely refined and used for creating tiny colorful 3-dimentional borders and even whole textiles. The technique 'orcis' that was used in Europe in recent times to create white plate dividers was used in ancient Peru to create plant fiber hairnets painted with shellfish purple. Fist-braiding for bands and ornamental slings was done in round, square and rectangular forms by manipulating up to 80-90 yarns over one hand. This technique is to my knowledge only used elsewhere in Japan for the round bands tying the belt of the kimono, and by the herders of Tibet, who also make rectangular fist-braids for slings.

A few techniques from the old world have not been found in preColumbian Peru: tablet weaving, crochet and knitting. Tablet weaving was used in ancient Mesopotamia and reached north to the Vikings, who used it for decorative bands. Crochet probably developed from "tambouring" and reached Europe in the 1700 century from the Middle East. Knitting also comes from Mesopotamia and only reached Europe in the 16th century.

\section{A brief description of the preColumbian textiles over the last $\mathbf{3 0 0 0}$ years}

\section{The earliest clothing}

For thousands of years before our era women wore string skirts - the oldest ones are found in the Tarapaca desert in northern Chile and are from 7000 BC. and sometimes dyed red with madder on cotton or camelid fiber.

Around the year 0 the coastal people in southern Peru/northern Chile changed their costume. The men had been wearing only loincloths and the women string skirts, but both genders around that time seemed to have left this custom for the tunic, probably inspired by the highland people. 
The tunic

The tunic was - in many variations - worn by both men and women in the preColumbian world.

Through the following millenia, the men wore a tunic mostly with a vertical warp, vertical neck slit and vertical arm slits. The women wore a tunic mostly with a horizontal warp, horizontal neck- and arm slit. Horizontal stripes were generally reserved for women and vertical for men, though exceptions occurred.

The men's tunics were worn loose and the women's either loose or held together by a belt. The tunics could be short or long, narrow or wide, changing with time and culture. Mostly the women wore longer tunics reaching below the knees and the men shorter ones. The men wore a loincloth under the tunic, so their tunics could be very short. In some cultures women also wore wraparound dresses.

\section{Techniques}

Most preColumbian cultures used many different textile producing techniques. In the following only a few, very characteristic techniques will be mentioned.

\section{Some indications to help identify a preColumbian textile.}

Paracas/Nazca 500 BC-500 AD

Camelid fiber or cotton plain weave fabrics with camelid fiber embroidery in stem stitch in vivid colors. Short wrap-around skirts for men and short tunics, turbans and large mantles with embroidery along the edges, and sometimes all over. The early imagery was geometric and later more naturalistic anthropomorphs mixed with animals - a flying shark-man, for instance.

Intricate 3-dimensional looping was used to create garment edgings and occasionally whole textiles. Preferred colors were red and blue, but all colors were used, and many more techniques.

\section{Moche 100-650 AD}

Not many Moche textiles are found today. The climate on the north coast with its recurrent floods is not good for preserving organic material.

But the textiles that remain prove that their textile craft was elaborate. Tapestry weavings depicted many natural scenes - among them many images of human sacrifice. Geometric patterns were also prevalent, and techniques like double weave, discontinuous weave, gauze and brocade. The plain weave was set up with single spun, paired warps. 
Middle Horizon 500-900 AD

The Wari/Tiwanaku originated in the highlands and influenced all coastal Peru.

The large tapestry woven tunics were woven on the vertical two beam loom.

The iconography was not as naturalistic as Moche/ Lambayeque. The tapestry tunics were in their images abstracted following specific and precise rules and could only be "read" by specialists. Some of the tapestries had a fineness of 70-80 camelid wefts per $\mathrm{cm}$.

Lambayeque 900-1100 AD

The Lambayeque tapestries have very natural figurative images, representing both ritual but also everyday scenes. Flowers and animals were a common image - often with roots and tentacles stretching out from the fabric. The yarns were not as tightly packed as the Wari/ Tiwanaku tapestries. The large tunics were woven in plain weave cotton, and had sewed-on patches of tapestry, often with 3-dimentional decorations. The green color (indigo and some yellow plant dye) was very predominant. Unlike the other preColumbian weavings the Lambayeque used a very variable spin and ply.

Late intermediate: 1200-1500 AD

The coastal textiles were mainly cotton with smaller decorations in camelid fiber. The techniques were many - brocade, gauze weave and double weave in brown and tan were predominant. The large brocaded animals wearing a crescent feather imitation headpiece were abundant on the north coast. On the south coast tiny geometric intertwined patterns in tapestry and brocade were in vogue. The central coast sported intricate gauze woven shawls, complicated knotted hairnets painted with sea shell purpur, or cotton tapestries with edgy representations of seabirds and fish.

The male tunics from the coast in this period were rather short and could be with or without sleeves. They often had an added fringe at the bottom (looped fringe is an Ychsma indication).

North coast (Chimu) textiles had mainly single spun, paired warps whereas Central coast (Ychsma/ Chancay) and south coast mostly used 2-ply yarns.

Late Horizon: 1450-1550 AD

The Inka wove their tunics and wrap-around-dresses on vertical two beam looms. Inka designs are "minimalistic" compared to the designs of earlier cultures and have mostly geometric motifs. A large step fret decoration was often woven around the neck and a band with geometric "tukapu" squares often decorated the center of male tunics. These tukapus are said to indicate messages - such as the hierarchical and geographic status of the wearer. 
But they are so far not fully understood. The Inkas kept track of everything happening in their world in Quipus - a system of plied and knotted yarns mostly in cotton. They also have not been fully deciphered.

Camelid fibers are predominant in the Inka textiles and many are woven in discontinuous weave. The Inka also braided exquisite slings. They wore them around the head and with time these slings became so large and elaborate that they were unfit for herding/hunting and only served as decorative headbands.

Colonial: $1536-1800 A D$

Male tunics and female wrap-around dresses continued to be worn for centuries after the conquest. The tapestry designs became influenced from Europe and lost their edgy shapes. Rounded forms, silk yarns and Christian symbols indicate that a textile is definitely made after the conquest.

\section{Explanation of terms in textile analysis}

$\mathrm{S}$ : is a single spun yarn, spun in $\mathrm{S}$ direction.

$Z$ : is a single spun yarn, spun in Z direction.

$2 \mathrm{~S}$ : is two single spun yarns - spun in $\mathrm{Z}$ and plied in $\mathrm{S}$.

$2 Z$ : is two single spun yarns - spun in $S$ and plied in $Z$.

In the indications of thread count, the warp measure is before the weft measure.

In the indications of size of a textile, the warp measure is before the weft measure.

The thread count is average ( 3 counts per textile)

All measurements are in centimeters.

Warp/weft rep is also called warp or weft faced.

Supplementary weft patterns are:

Lancée: a supplementary weft pattern on top of a woven fabric, where the supplementary weft yarns reach from selvedge to selvedge. Brocade: the supplementary wefts only cover part of the warp.

The definitions of the techniques are from Irene Emery (see bibliography). 


\section{Bibliography}

Bergh, Susan (2012) Wari, Lords of the Ancient Andes, The Cleveland Museum of Art, Thames \& Hudson, New York.

Bjerregaard, Lena (2001) Doubletten — puzzles that could maybe some day be reconstructed, Baessler-Archiv, band 49, Berlin.

Bjerregaard, Lena (2002) Pre-Columbian Treasures in the National Museum of Copenhagen, Corpus Antiquitatum Americanensium/The National Museum of Denmark, Copenhagen.

Bjerregaard, Lena (2006) Haar als Symbol und Werkstoff; Haar-Objekte in den Staatlichen Museen zu Berlin, Journal-Ethnologie 6.

Bjerregaard, Lena (2010) Fist-braided bands used as headgear in pre-Hispanic Peru, Archaeological Textile Newsletter 51:2-13, University of Copenhagen.

Bjerregaard, Lena (2011) Pre Columbian Hairnets in the Ethnological Museum, Berlin, Baessler Archive, no. 57, Berlin.

Bjerregaard, Lena (2011) Redecillas Purpuras de la Costa Central, Jornadas V de Textiles Precolombinos, Universidad Autonoma Barcelona.

Bjerregaard, Lena (2016) Lambayeque-style textiles in the Ethnologisches Museum, Berlin, Nuevo Mundo Mundos Nuevos, online http://nuevomundo.revues. org/69290

Bjerregaard, Lena (2016) Non-woven Textile Techniques in Pre-Columbian Peru, Archaeological Textile Review 58:86-97.

Bjerregaard, Lena (Ed.) (2017) PreColumbian Textiles in the Ethnological Museum in Berlin, Zea Books, Lincoln, NE, online https://digitalcommons.unl.edu/zeabook/52/

Boetzkes, Manfred, Wolfgang Gockel and Manfred Höhl (Eds.) (1986) Alt-Peru. Auf den Spuren der Zivilisation, Katalog-Verlag EA Quensen $\mathrm{GmbH}$, Lamspringe.

Boetzkes, Manfred (Ed.) (1994), Welten in Vitrinen. 150 Jahre Roemer-Museum, Catalogue from Roemer-Museum Hildesheim.

Boone, Elisabeth Hill, ed. (1996) Andean Art at Dumbarton Oaks, Vol 2., Washington, D.C.

Boytner, Ran (1998): The Pacatnamú Textiles: A Study of Identity and Function. Ph.D. dissertation, University of California, Los Angeles.

D'Harcourt, Raoul (1962) Textiles of Ancient Peru and Their Techniques, University of Washington Press, Seattle.

Donnan, Chris B. (1986) An Elaborate Textile Fragment from the Major Quadrangle, The Pacatnamu Papers, vol. 1, pp. 109-114. Museum of Cultural History, University of California, Los Angeles.

Dransart, Penelope and Helen Wolfe (2011) Textiles from the Andes, British Museum Press, London.

Emery, Irene (1966), The primary structures of fabrics, Thames and Hudson, London.

Frame, Mary (1986) Nasca Sprang Tassels: Structure, Technique and Order. Textile Museum Journal 25, 67-82, Washington, D.C.

Frame, Mary (1997) Textiles Chuquibamba, Museo de Arte, Lima.

Frame, Mary (2003) What the women were wearing: A deposit of early Nasca dresses and shawls, Textile Museum Journal, 42/43:13-53, Washington, D.C.

Frame, M., F. Vallejo, M. Ruales, and W. Tosso (2012) Ychsma textiles from a Late Horizon burial at Armatambo, Ñawpa Pacha (Institute of Andean Studies, Berkeley, CA) 32(1): 43-84. 
Frei, Karin, and Lena Bjerregaard (2017) Provenance investigations of raw materials in preColumbian textiles from Pachacamac; strontium isotope analyses, in Actas VII Pre-Columbian Textiles Conference in Copenhagen 2016, pp. 387-398, Zea Books, University of Nebraska-Lincoln, https://digitalcommons.unl.edu/pct7/22/

Gayton, A. H. (1955) A new type of ancient Peruvian shirt, American Antiquity, vol. 20, Utah.

Haeberli, Joerg (2002) Siguas 1: A newly identified Early Horizon Culture, Department of Arequipa, Peru, TSA Symposium Proceedings, http://digitalcommons.unl.edu/ tsaconf/392

Hecker, Gisela (1995) Die Grabungen von H. Ubbelohde-Doering in Pacatnamu, Nordperu, Berlin.

Jiménez Díaz, María Jesús (2009) Tradición de tradiciones, La coleccíon del Museo de América, Madrid.

Keck, Rudolf W. (Ed.) (1994) Gesammelte Welten. Das Erbe der Brüder Roemer und die Museumskultur in Hildesheim (1844-1994), Verlag Gebrüder Gerstenberg Hildesheim.

King, Heidi (2012) Peruvian Featherworks, Metropolitan Museum of Art, New York.

Kurella, Doris, and Inés de Castro (2013) Inka Könige der Anden, Linden-Museum, Stuttgart.

Lavalle, J. A., and G.J.A. González (1993) The textile art of Peru: Collection. Lima, Peru.

Lavalle, José Antonio de, and Rosario de Cárdenas Lavalle, eds. (1999), Textiles Milenarios del Peru, Lima.

Makowski, Krzysztof, Alfredo Rosenzweig, María Jesús Jiménez Diaz, and Jan Szemiński (2006) Weaving for the Afterlife, Peruvian Textiles from the Maiman Collection, Vol. I, Israel.

Makowski, Krzysztof et al. (2010) Señores de los Imperios del Sol, Banco de Crédito del Perú, Lima.

Montell, Gösta (1929) Dress and Ornament in Ancient Peru, Göteborg.

Oakland, Amy (2008) The string or grass skirt: an ancient garment in the southern Andes, Textile Society of America Symposium Proceedings, paper 120.

Oakland Rodman, Amy and Gioconda Arabel Fernandez Lopez (2005) North coast style after Moche: Clothing and identity at El Brujo, Chicama Valley, Peru, in Ricard Martin Reycraft, ed., Us and Them: Archaeology and Ethnicity in the Andes (64th annual SAA, Chicago, April 1999), Cotsen Institute of Archaeology, University of California, Los Angeles.

Paul, Anne (1990) Paracas Ritual Attire, Symbol of Authority in Ancient Peru, University of Oklahoma Press.

Pease G. Y., Franklin (1999) Los Incas: Arte y Símbolos, Banco de Credito del Perú, Lima, 1999.

Phipps, Elena, et al. (2004) The Colonial Andes, The Metropolitan Museum of Art, New York.

Phipps, Elena (2013) The Peruvian Four-Selvaged Cloth, Fowler museum Textile Series, No. 12, Los Angeles.

Pillsbury, Joanne (2002) Inka Unku: Strategy and Design in Colonial Peru, Studies in the History of Art, Cleveland.

Prümers, Heiko (2007) Zeitschrift für Archaeologie Aussereuropäischer Kulturen 2, Textiles de la Tumba del „Señor de Sipán", Peru, pp. 255-324.

Reid, James (1986) La Textileria Nasca, Culturas Precolumbinas, eds. José Antonio de Lavalle, Banco de Crédito del Perú, Lima. 
Reiss, Wilhelm, and Alphons Stübel (1880) Das Todenfeld von Ancon, Berlin.

Rickenbach, Judith, and Nikkibarla Calonder (2007) Textilien aus dem alten Peru: die Sammlungen der Abegg-Stiftung und des Museum Rietberg, Schweitz.

Rowe, Ann P. (1977) Warp-patterned Weaves of the Andes, Textile Museum, Washington, D.C.

Rowe, Ann P. (1984) Costumes and Featherwork of the Lords of Chimor, Textile Museum, Washington, D.C.

Rowe, Ann P. (1995-96) Inca Weaving and Costume, Textile Museum Journal, Textile Museum, Washington, D.C.

Rowe, Ann P. (2014) Technical reflections of highland-coastal relationships in late prehispanic tunics from Chillon and Chancay, Textiles, Technical Practice, and Power in the Andes, London.

Rowe, John Howland (1979) Standardization in Inca Tapestry Tunics, Junius B. Bird PreColumbian Textile Conference 1973, figs.1-3, pp. 246-47.

Shimada, Izumi (1985), Excavations on Huaca Grande: An Initial View of the Elite of Pampa Grande, Peru, Journal of Field Archaeology 12.

Shimada, Izumi (1995) Cultura Sicán. Dios, riqueza y poder en la costa norte del Perú, Lima: EDUBANCO, Fundación del Banco Continental para el fomento de la Educación y la Cultura, 1995

Stone-Miller, Rebecca (1992) To Weave for the Sun, Andean Textiles in the Museum of Fine Arts, Boston.

Strelow, Renate (1996) Gewebe mit Unterbrochenen Ketten aus dem Vorspanischen Peru (Pre-Hispanic Peruvian Textiles with Discontinuous Warp), Neue Folge 61, Museum für Völkerkunde, Berlin.

Young-Sánchez, Margaret (1969) The Chancay Textile Tradition: Textiles from Lauri in the Collection of the Amano Museum, Lima.

Young-Sánchez, Margaret (2004), Tiwanaku, Ancestors of the Inca, Denver Art Museum/ University of Nebraska Press.

Young-Sánchez, Margaret and Fronia W. Simpson (2006) Andean Textile Traditions, Papers from the 2001 Mayer Center Symposium at the Denver Art Museum, Denver Art Museum, Denver, Colorado.

Exhibition catalogues: No author

Paracas, tresors inedits du Perou ancient (2008) Musee quai Branly, Paris.

Inka. Textiles and ornaments of the Andes. (2019) Royal Museums of Art and History, Bruxelles

\section{Conference papers:}

Ed. Solanilla Demestre, Victoria (2000), Actas I, Jornadas Internacionales de Textiles Precolombinas, Universitat Autonoma de Barcelona.

Ed. Solanilla Demestre, Victoria (2002), Actas II, Jornadas Internacionales de Textiles Precolombinas, Universitat Autonoma de Barcelona.

Ed. Solanilla Demestre, Victoria (2006), Actas III, Jornadas Internacionales de Textiles Precolombinas, Universitat Autonoma de Barcelona. 
Ed. Solanilla Demestre, Victoria (2009), Actas IV, Jornadas Internacionales de Textiles Precolombinas, Universitat Autonoma de Barcelona.

Ed. Solanilla Demestre, Victoria (2011), Actas V, Jornadas Internacionales de Textiles Precolombinas, Universitat Autonoma de Barcelona.

Ed. Desrosiers, Sophie (2017), Actas VI, Pre-Columbian Textile Conference 2014, Quai Branly, Paris, Mundo Nuevo - Nuevos Mundos, Colloques. https://nuevomundo. revues.org/69877

Ed. Bjerregaard, Lena and Ann Peters (2017), Actas VII, Pre-Columbian Textile Conference 2016, Copenhagen, Zea Books, University of Nebraska-Lincoln. https://digitalcommons.unl.edu/zeabook/59/

Ed. Bjerregaard, Lena and Ann Peters (forthcoming 2020) Actas VIII, Pre-Columbian Textile Conference 2019, Royal Museums of Art and History, Bruxelles, http://digitalcommons. unl.edu/zeabook/

\section{Unedited:}

Prümers, Heiko, (1983) Präkolumbische Textilien von der Mittleren Küste Perus aus der Sammlung des Roemer Museum Hildesheim. M.A. Dissertation. 


\section{PARACAS/NAZCA - 500 BC - 500 AD}

\section{Museum number: Dauerleihgabe STIFTUNG NIEDERSACHSEN, coll. Zarnitz, L/SN 12}

Item: Edge band from turban or skirt. Style: Paracas /Nazca, 500 BC-500AD

Size: $35 \times 6 \mathrm{~cm}$

Material/technique: Plain weave with soumack embroidery over 2 yarns, under one. Cotton plain weave: $2 \mathrm{~S}$. Threadcount is $14 \times 14$ per $\mathrm{cm}$. Embroidery: Camelid fiber $2 \mathrm{~S}$. Further description: the cotton backing material is almost gone. It can not be stated what is warp and what is weft.

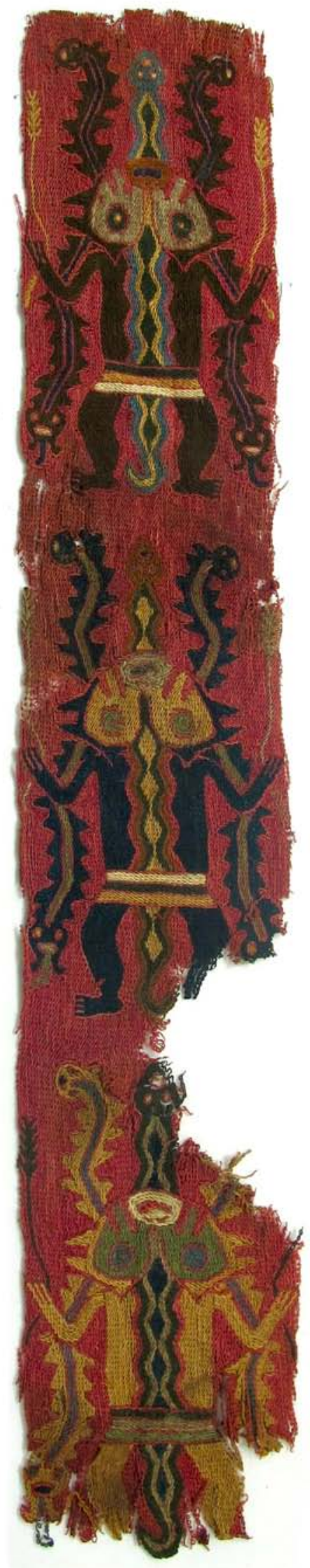




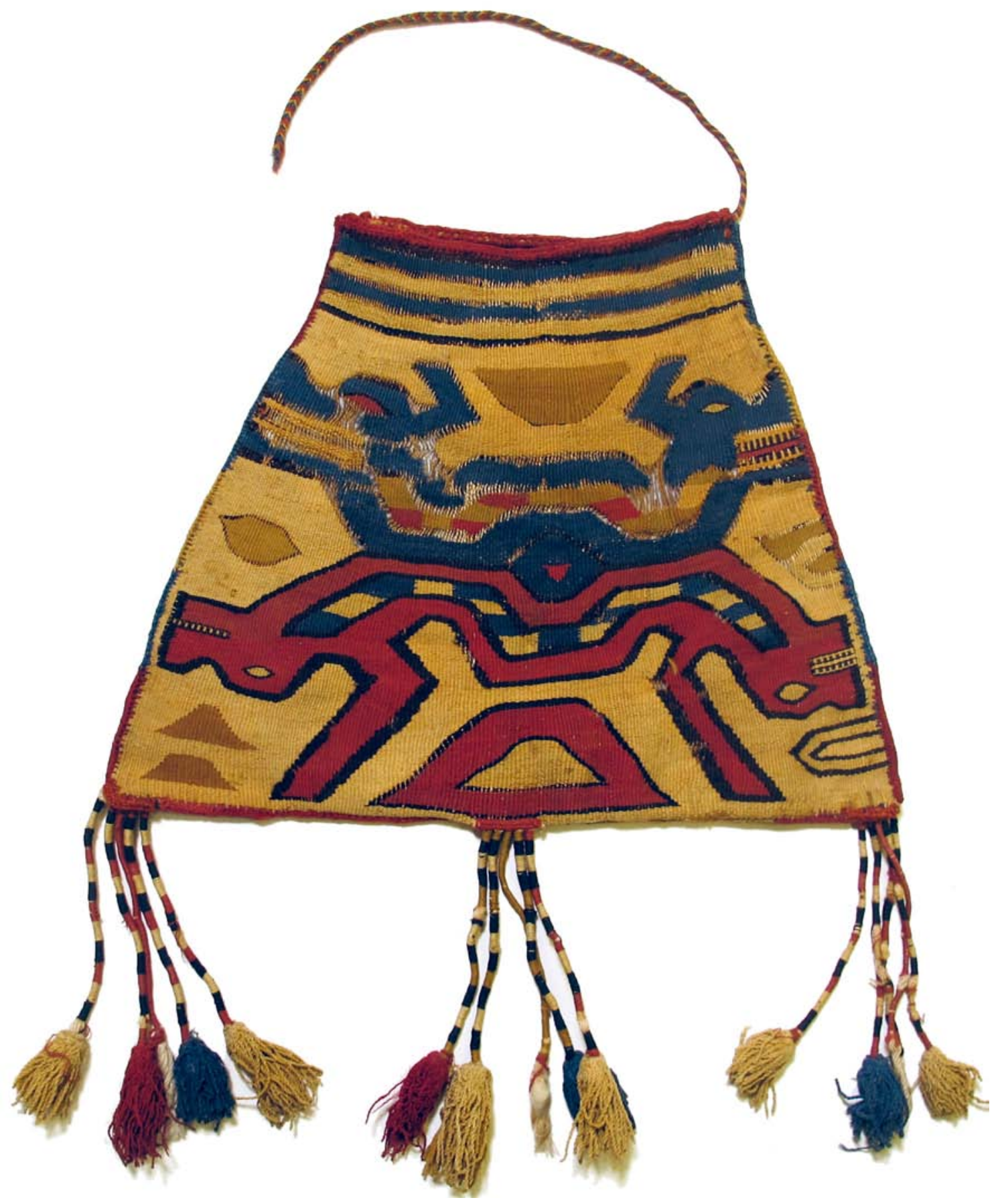

\section{Museum number: V 8.961}

Item: Bag

Style: Nazca

Size: $23 \times 30 \mathrm{~cm}$

Material/technique: Tapestry weave. Warp: cotton $2 \mathrm{~S}$ (a brown and a white twined together). Weft: camelid fiber $2 \mathrm{~S}$. The threadcount is $8 \mathrm{x}$ 30 per $\mathrm{cm}$.

Further description: The edges of the bag are sewn together/ adorned on edge (top) and fold (bottom) with loop stitch embroidery. At top is a flat 4 braid - for strap - attached at one edge, fragmented at other. At bottom 3 groups of wrapped yarns ending in a tassel. 4 yarns in each group. These are cotton yarns $2 \mathrm{~S}$ wrapped with camelid fiber $2 \mathrm{~S}$. These wraps with tassels are $13 \mathrm{~cm}$ long. 


\section{Museum number: V 9.300}

Item: Woven tassel

Style: Nazca

Size: $35 \times 8 \mathrm{~cm}$

Material/technique: A plain weave (camelid fiber 2S) cloth 8 $\mathrm{cm}$ wide is folded along the warp center, so it is double and the two weft edges are partly sewn together along the right side. The threadcount is $12 \times 5$ per $\mathrm{cm}$.

$17 \mathrm{~cm}$ loose warp-fringe below - at top $4 \mathrm{~cm}$ warp loops. The woven part is adorned with chain-stitch and cross knit loop stitch.

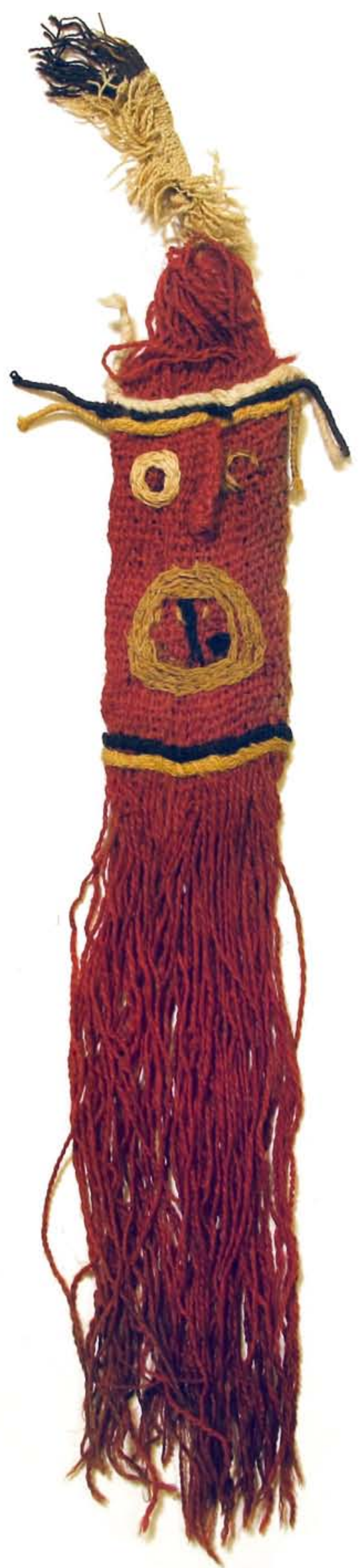




\section{MIDDLE HORIZON - 400-800 AD}

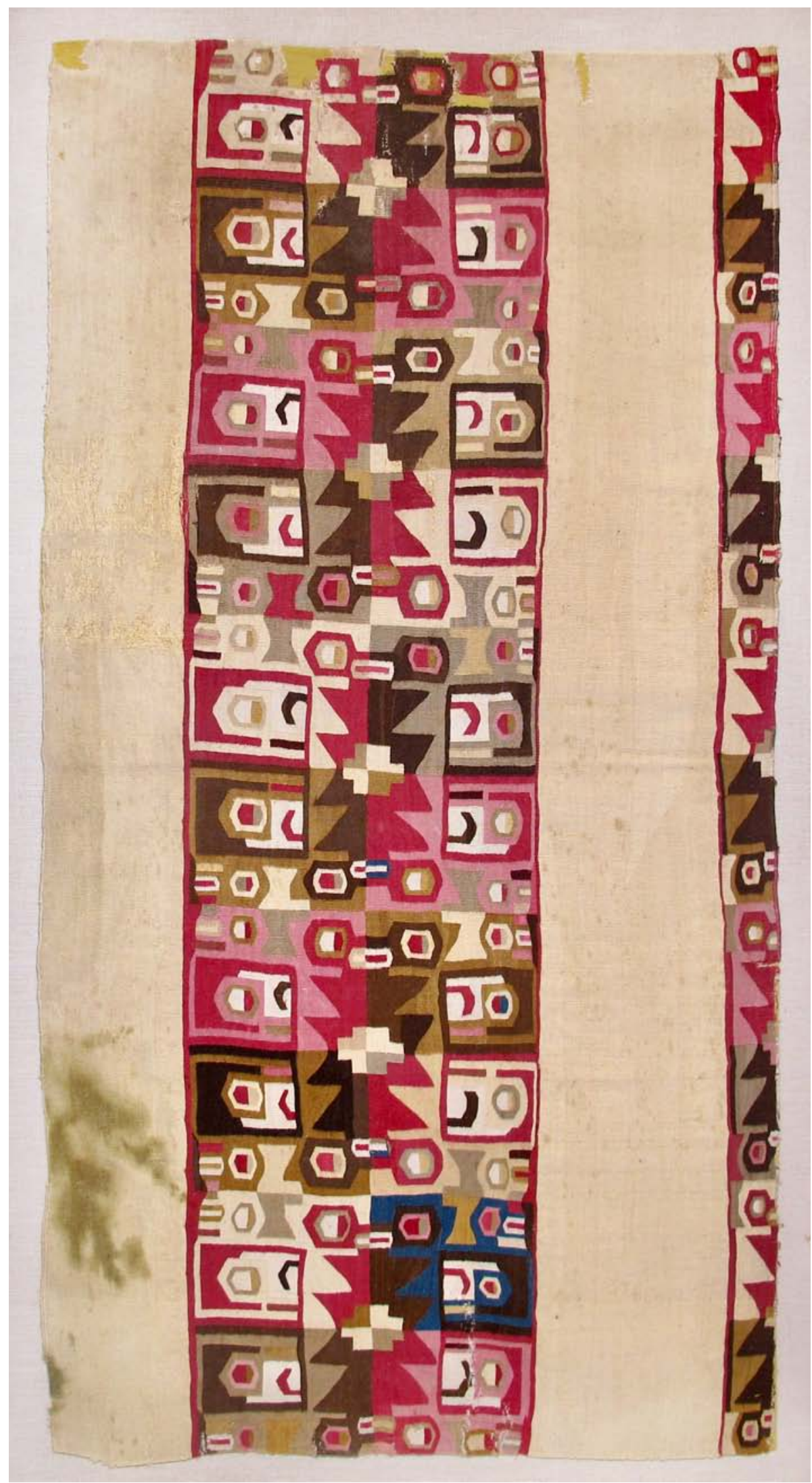

\section{Museum number: Leihgabe STIFTUNG NIEDERSACHSEN, Schenkung Zarnitz/Pelling}

Item: $1 / 4$ th of a tunic

Style: Wari

Size: 56 x $108 \mathrm{~cm}$

Material/technique: Interlocked tapestry. In various places in the white parts there are "lazy lines" (maybe - an indication that several weavers were engaged side by side).

Cotton $2 \mathrm{~S}$ warps, camelid fiber $2 \mathrm{~S}$ wefts. The threadcount is $12 \times 48$ per $\mathrm{cm}$.

Further description: At intervals two or more warps are tan instead of white but somehow not following/indicating the pattern. The side designs are not completely aligned with the center patterns. But close $(0,5-1 \mathrm{~cm}$ apart $)$ Notice the sparse blue....

The fragment has NO warp-selvedges but fragments of weft-selvedges at both sides. Also some side edge embroidery is left: at one end $38 \mathrm{~cm}$ of embroidery (an 8-shape stitching to another cloth), then $30 \mathrm{~cm}$ loop stitch embroidery (indicating the arm hole), and the last 38 cm without any embroidery.

Thus indicating that the textile here has the shoulderline in the horizontal center - and is then cut off horizontally 54 $\mathrm{cm}$ down the front and back of a tunic panel.

The textile is a long term loan of the Savings Bank Foundation of Lower Saxony. 


\section{Museum number: V 8.957}

Item: Fragment

Style: Late Middle Horizon, Central coast

Size: $45 \times 35 \mathrm{~cm}$

Material/technique: Two panels sewn together. Slit tapestry, warp cotton 3Z, weft camelid fiber 2S. At lower left edge is a piece of plain weave cotton $(Z$ yarns). The threadcount is $18 \mathrm{x}$ 11 per $\mathrm{cm}$.

\section{Museum number: V 9.061}

Item: Fragment

Style: Late Middle Horizon, South Coast

Size: $22 \times 11 \mathrm{~cm}$

Material/technique: Interlocked (every $2 \mathrm{~mm}$ ) tapestry, warp $2 \mathrm{~S}$ cotton; weft $2 \mathrm{~S}$ camelid fiber. The threadcount is $9 \times 42$ per $\mathrm{cm}$.

Further description: V9050 is a fragment of the same textile.
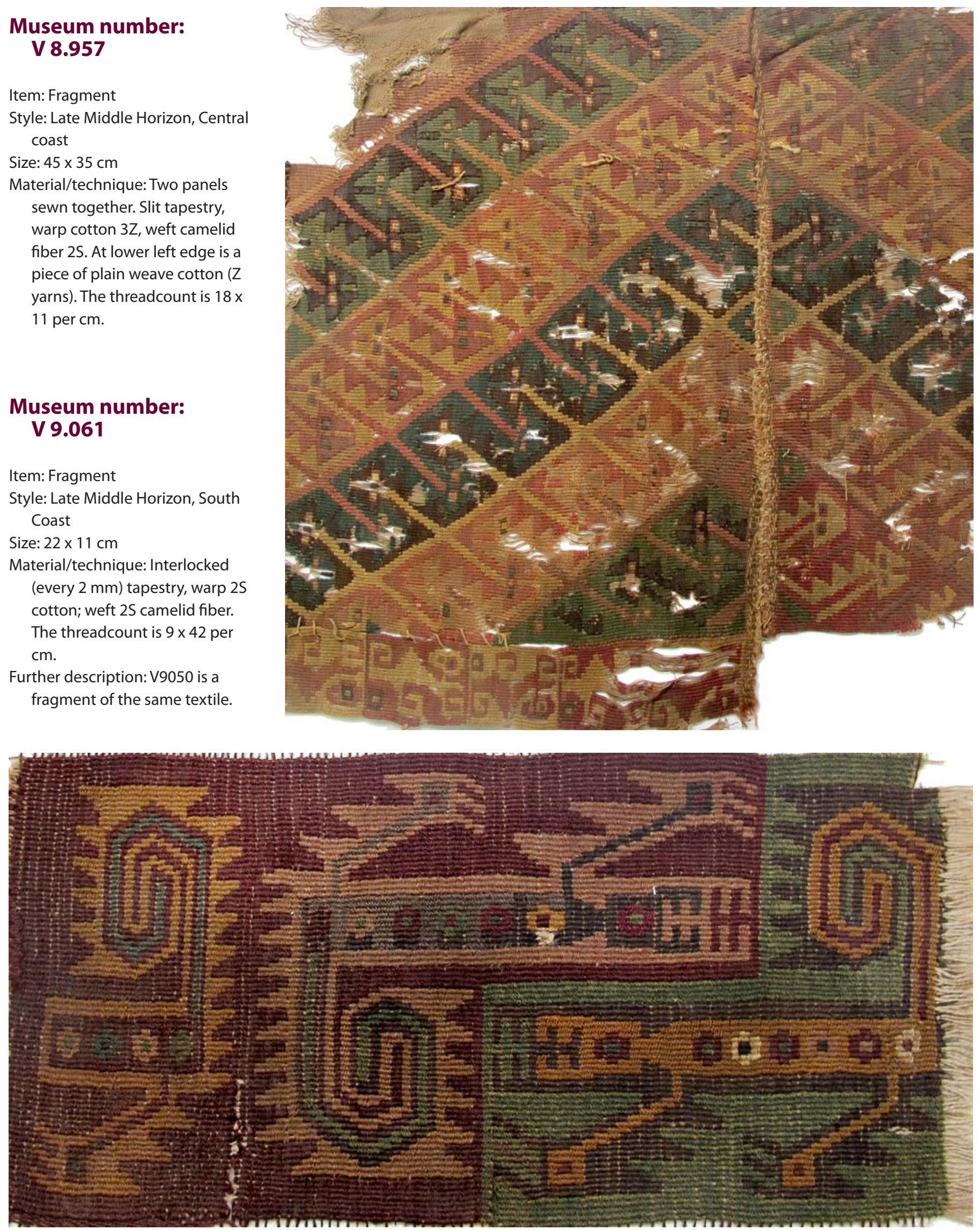


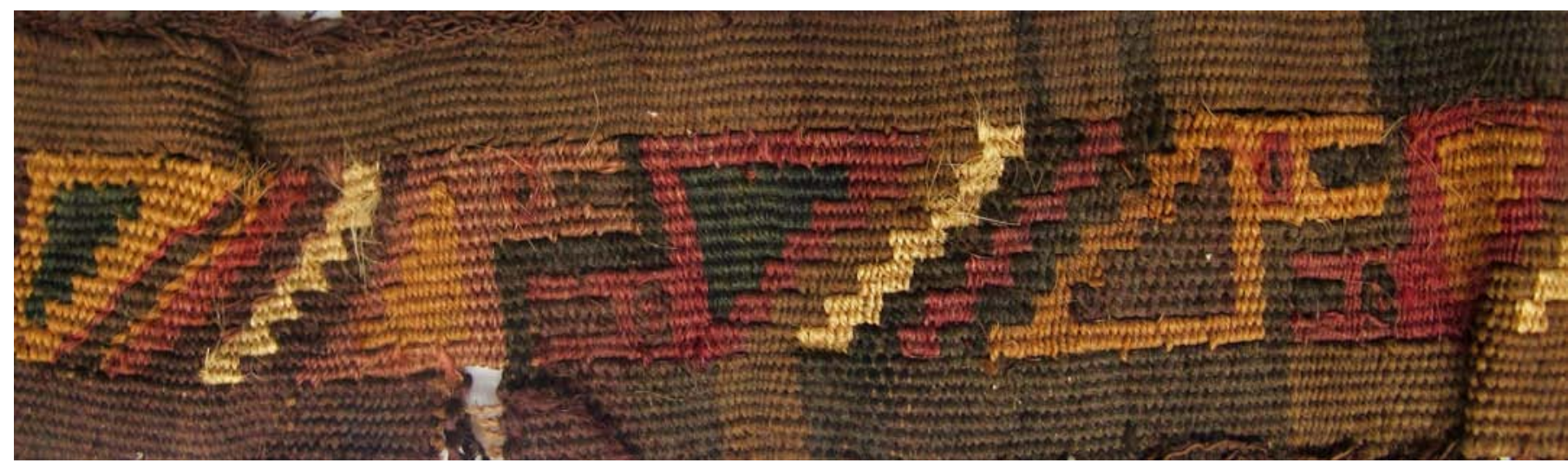

\section{Museum number: V 9.054}

Item: Band

Style: Middle Horizon

Size: 47 x 2,5-3 cm

Material/technique: Interlocked tapestry (every 5 wefts), warp cotton 2Z, weft camelid fiber 2S. The threadcount is $12 \times 42$.

Further description: At one end is warp selvedge, at two sides are side selvedges. Fragments of a plain weave cotton material (S, threadcount: $20 \times 20$ per $\mathrm{cm}$ ) at the sides - to which the band has been stitched.

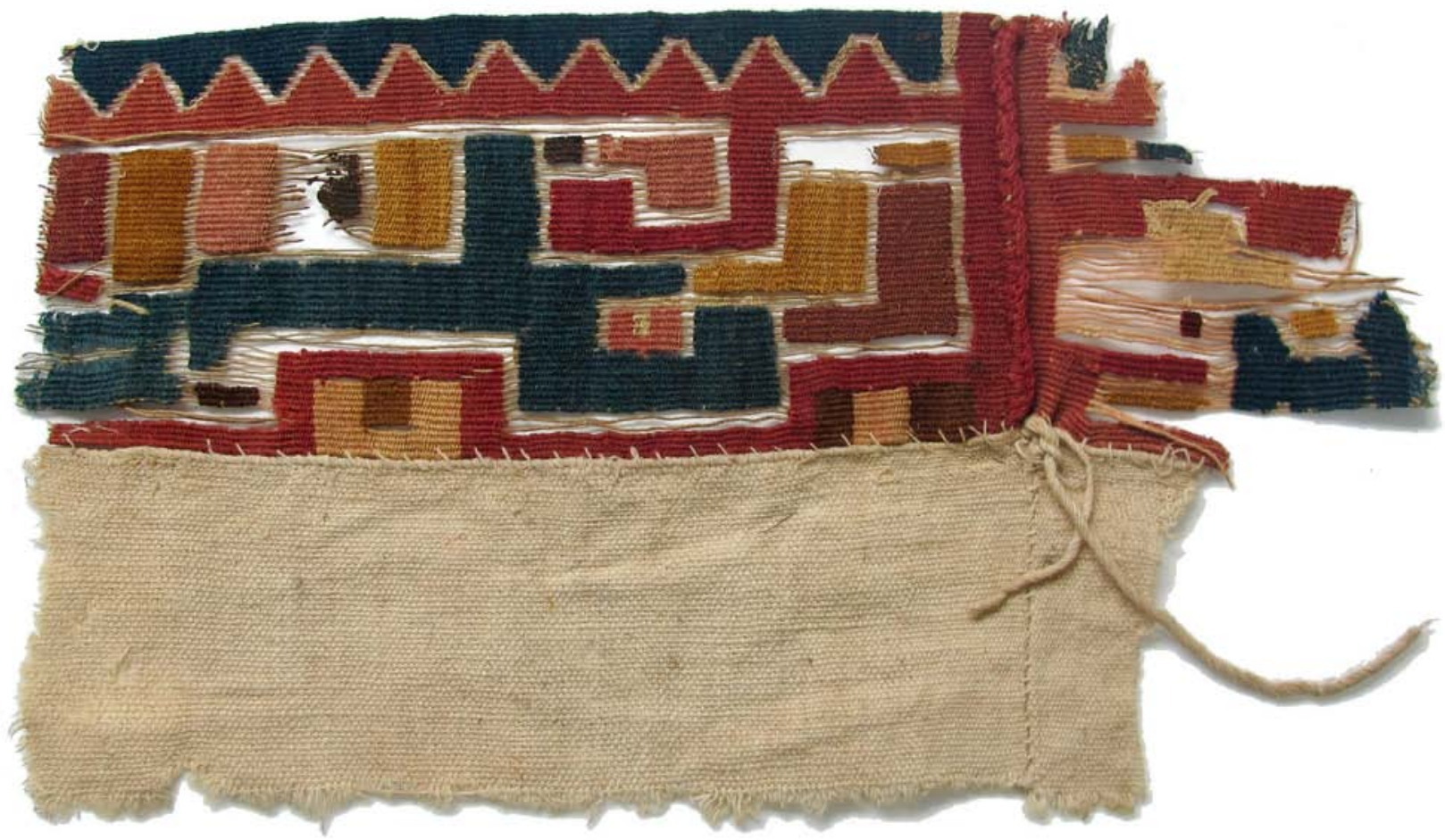

\section{Museum number: V 9.082}

Item: Fragment

Style: Middle Horizon, North or South Coast.

Size: $25 \times 13 \mathrm{~cm}$

Material/technique: The fragment consists of two panels sewn together. Each panel has:

1. an interlocked (every 6-7 $\mathrm{mm}$ ) tapestry band. Warp in the larger panel is camelid fiber $2 \mathrm{~S}$, in the smaller panel camelid fiber $2 \mathrm{Z}$.

Weft $2 \mathrm{~S}$ camelid fiber in both panels. The two panels are sewn together with loop stitch embroidery. The threadcount is $9 \times 46$ per $\mathrm{cm}$. 2. a plain weave cotton textile (two panels), warp is paired, both warp and weft are single $\mathrm{S}$. The threadcount is 9 (paired) $\mathrm{x} 10$ per $\mathrm{cm}$. The warp selvedge is stitched on to the tapestry band (that has warp lengthwise). 


\section{Museum number: V 9.145}

Item: Fragment

Style: Late Middle Horizon, Central/ North Coast,

Size: $68 \times 37 \mathrm{~cm}$

Material/technique: The textile is in plain weave cotton $2 Z$ (both warp and weft). The threadcount is $7 x$ 12 per $\mathrm{cm}$ in the plain weave. The textile has tapestry patterning with a threadcount of $7 \times 26$ per $\mathrm{cm}$. The tapestry warp is the plain weave warp and the weft is $2 \mathrm{Z}$ cotton.

Further description:

The textile consists of two fragments sewn together along their warp selvedges. This sewing is probably not original - the tapestry patterning seem not to belong together. Both fragments have a side selvedge aligned vertically to the right in photo.

In Textile Museum, Washington is a similar complete tunic (TM1969.38.1). It is a short tunic with sleeves. The tapestry part consist of 4 pieces that have been appliqued to a basic cotton textile with seams at shoulder and center front and back.

\section{Museum number: V $\mathbf{9 . 2 2 8}$}

\section{Item: Fragment}

Style: Middle Horizon

Size: $28 \times 29 \mathrm{~cm}$

Material/technique: 4 dovetailed tapestry bands (7 $\mathrm{cm}$ wide) stitched together. Cotton $2 \mathrm{~S}$ warp, camelid fiber $2 \mathrm{~S}$ weft. The threadcount is $7 \times 40$ per $\mathrm{cm}$.

Further description: No warp selvedges.

Litterature: Raoul D'Harcourt, 1966, pl. 8, Tiwanacu.
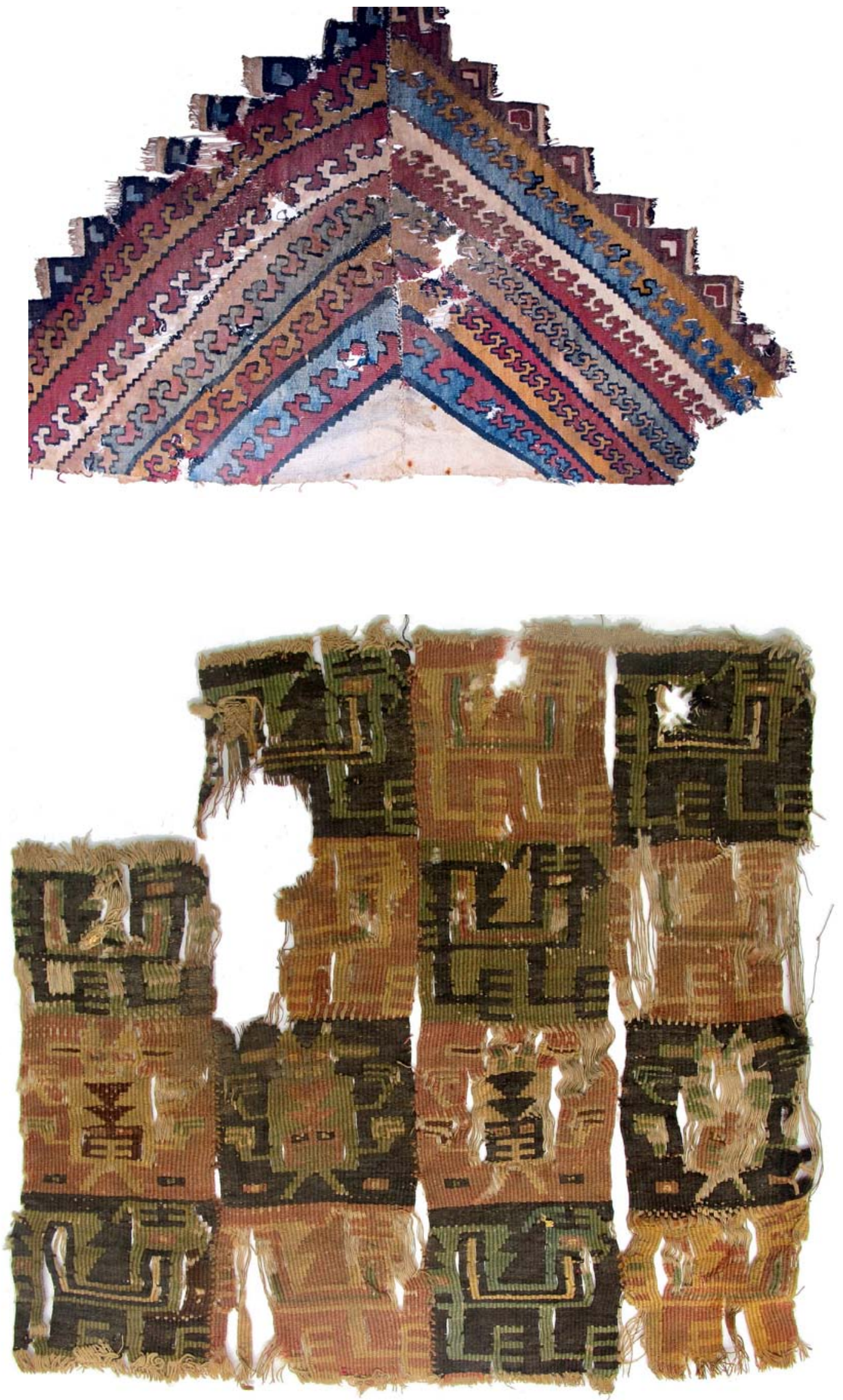


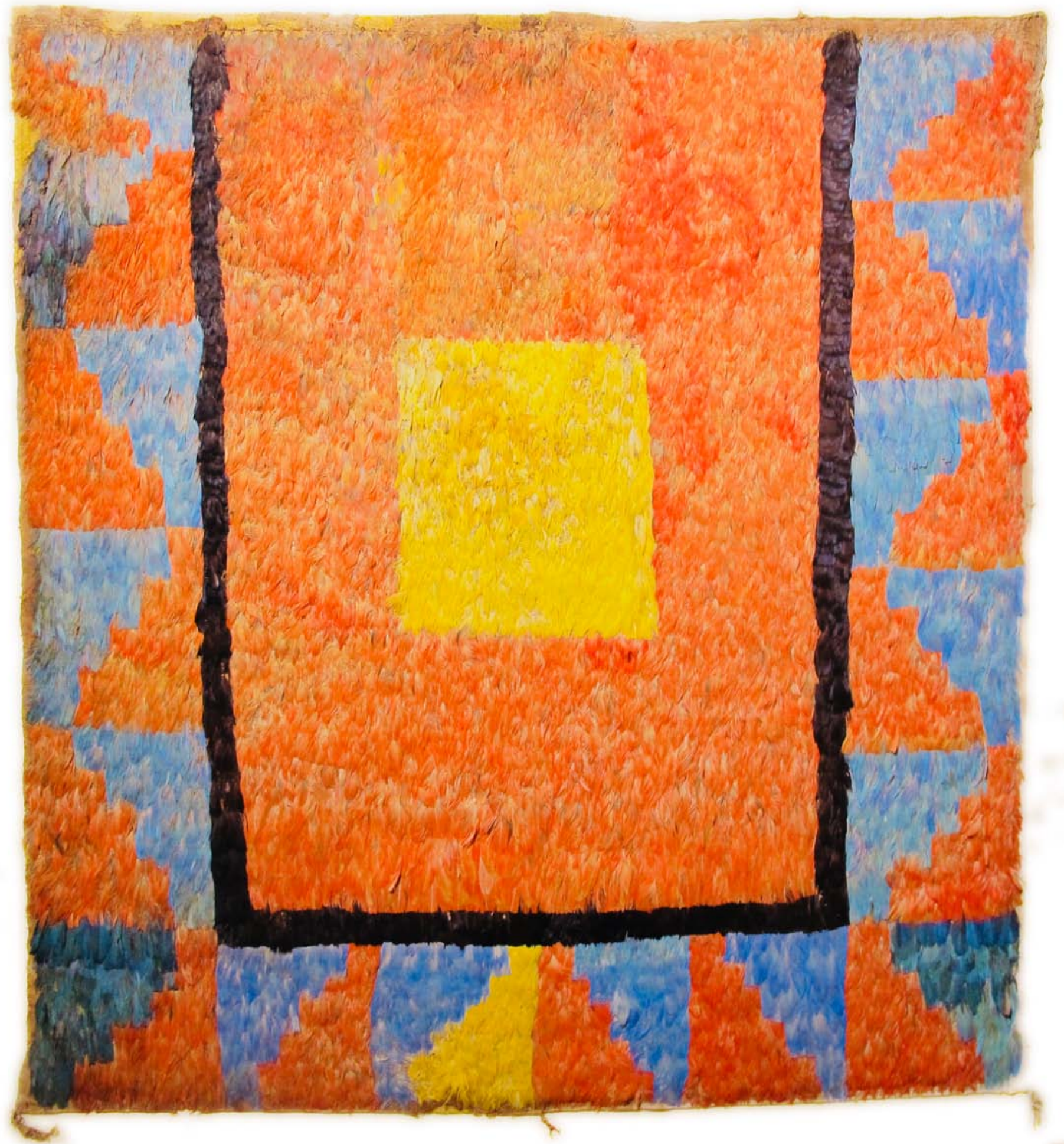

\section{Museum number: V 10.399 a}

Item: Half of a tunic

Style: Central or South coast, $400-600$ AD

Size: $106 \times 100 \mathrm{~cm}$

Material/technique: The base cloth of the textile is cotton 25 woven in plain weave. The thread count is $10 \times 7$ per $\mathrm{cm}$.

Feathers in different colors are stitched on as feather fringes made with two tying cords.

Gift by the Museum Society on the occasion of the 150th anniversary of the Roemer-Museum, 1996. 


\section{LAMBAYEQUE - 900-1300 AD}
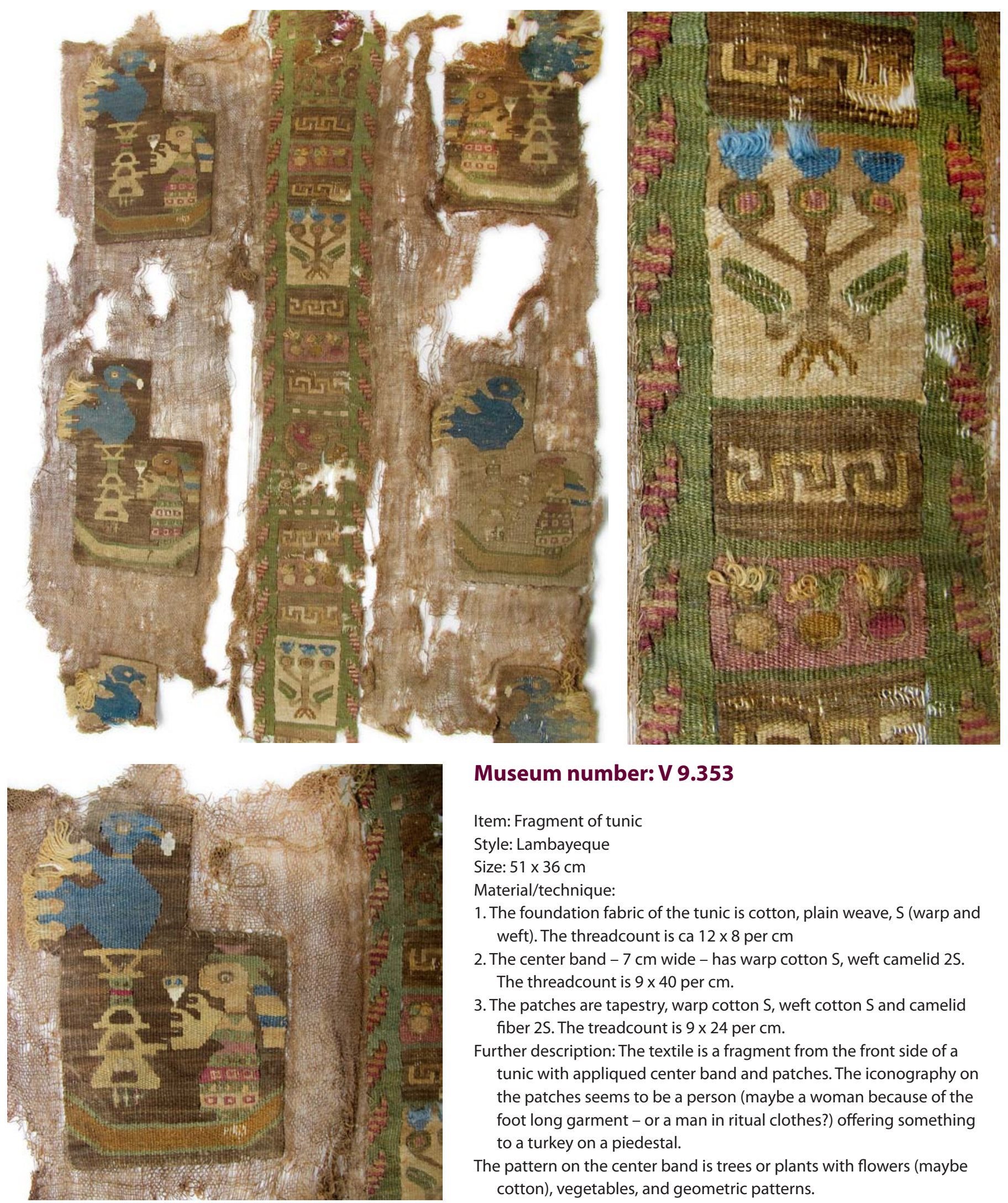

Museum number: V $\mathbf{9 . 3 5 3}$

Item: Fragment of tunic

Style: Lambayeque

Size: $51 \times 36 \mathrm{~cm}$

Material/technique:

1. The foundation fabric of the tunic is cotton, plain weave, $S$ (warp and weft). The threadcount is ca $12 \times 8$ per $\mathrm{cm}$

2. The center band $-7 \mathrm{~cm}$ wide - has warp cotton $\mathrm{S}$, weft camelid $2 \mathrm{~S}$. The threadcount is $9 \times 40$ per $\mathrm{cm}$.

3. The patches are tapestry, warp cotton $\mathrm{S}$, weft cotton $\mathrm{S}$ and camelid fiber $2 \mathrm{~S}$. The treadcount is $9 \times 24$ per $\mathrm{cm}$.

Further description: The textile is a fragment from the front side of a tunic with appliqued center band and patches. The iconography on the patches seems to be a person (maybe a woman because of the foot long garment - or a man in ritual clothes?) offering something to a turkey on a piedestal.

The pattern on the center band is trees or plants with flowers (maybe cotton), vegetables, and geometric patterns. 

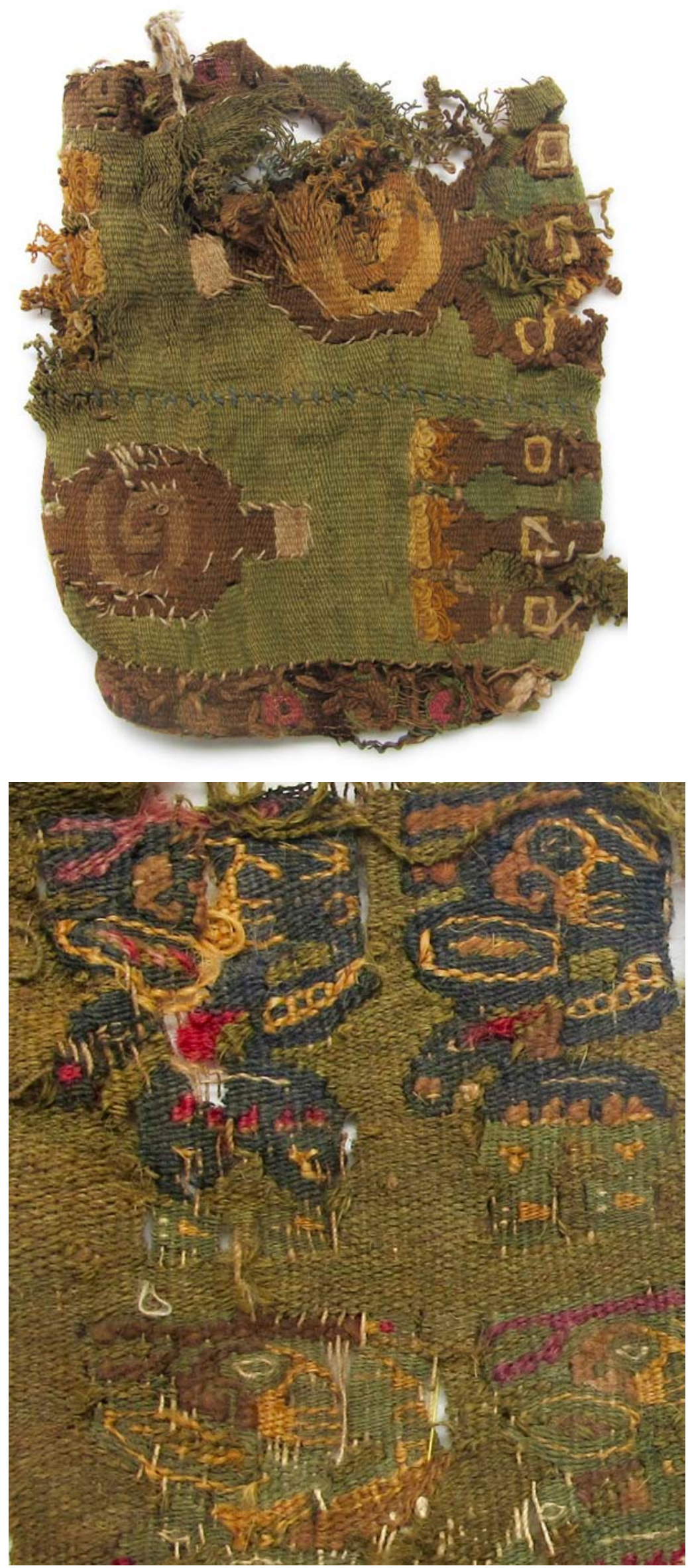

\section{Museum number: V 9.309}

Item: Bag

Style: Lambayeque

Size: $18 \times 15$ per $\mathrm{cm}$

Material/ technique: Slit tapestry with occational 3-dimensional looping (for flowers). Warps: cotton S, wefts: camelid fiber S.

Further description:

The bag is a reuse of bands: In the center two $7 \mathrm{~cm}$ wide bands from a tunic center band, and at top and bottom two $\mathrm{cm}$ wide bands.

\section{Museum number: V 9.294}

Item: Fragment from center band of tunic Style: Lambayeque

Size: $16 \times 6 \mathrm{~cm}$

Material/technique: Tapestry: warp cotton, 2Z, weft camelid fiber $2 \mathrm{~S}$. The threadcount is $11 \times 26$ per $\mathrm{cm}$.

There are fragments of sewing threads on the two side selvedges.

Further description: The iconography is of anthromorphic figures with bird's heads and carrying bundles.

V 9.294 and V 9.193 are from the same textile. 


\section{Museum number: V 9.279}

Item: Fragment from center band of tunic

Style: Lambayeque

Size: $21 \times 7 \mathrm{~cm}$

Material/technique: Slit tapestry, warp cotton S, weft camelid fiber $2 \mathrm{~S}$. The threadcount is 6-7 $\times 30$ per $\mathrm{cm}$. Along the side selvedges are fragments of sewing threads used to attach the band to a foundation textile. A few threads of this fabric (cotton S) are left in place.

The iconography is of a stylized high status person (large ear spools, pyramid base) wearing a huge hat.

\section{Museum number: V 9.199}

Item: Fragment of tunic

Style: Lambayeque

Size: $44 \times 10 \mathrm{~cm}$

Material/technique: The fragment consists of 3 parts: all only have side selvedges.

1. in the center is a cotton $S$ plain weave band $5 \mathrm{~cm}$ wide. The threadcount is $22 \times 9$ per $\mathrm{cm}$.

2. to both sides (lengthwise) of this band is sewn a tapestry band (no fringe) $3 \mathrm{~cm}$ wide with step fret patterns. $2 Z$ cotton warps. Wefts: $2 S$ camelid fiber and paired $Z$ cotton. The threadcount is $6-7 \times 20-$ 28 per $\mathrm{cm}$.
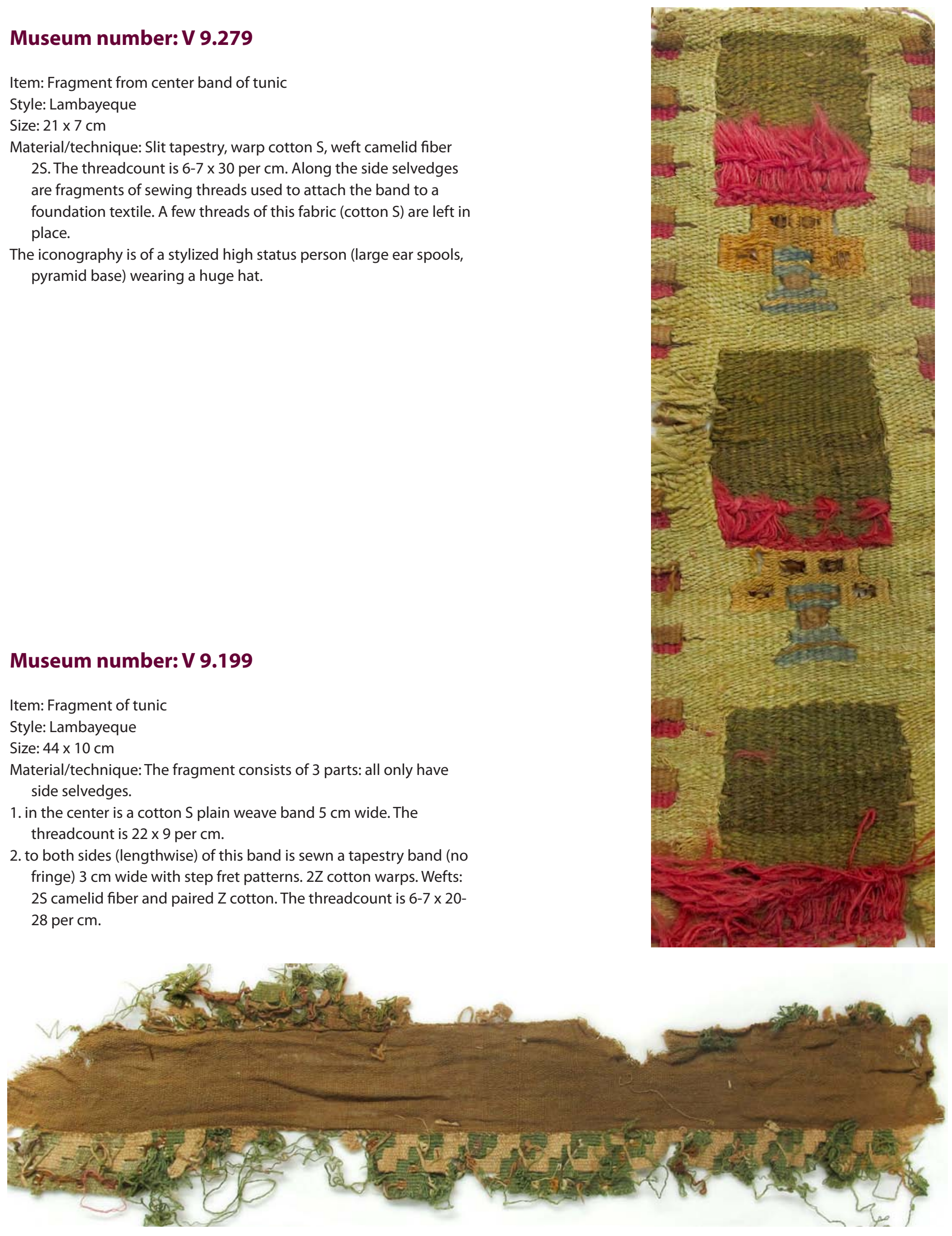

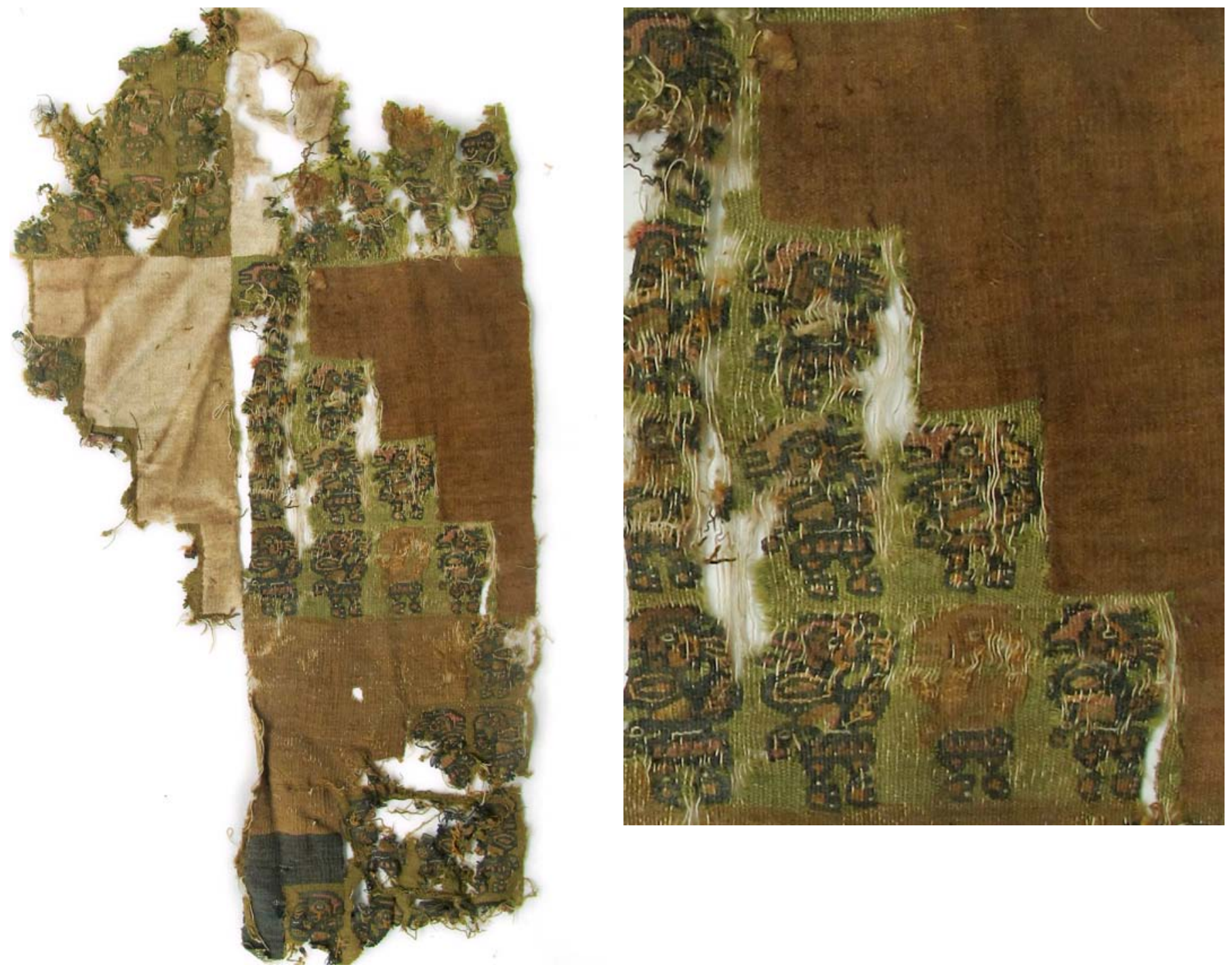

\section{Museum number: V 9.193}

Item: Fragment of tunic

Style: Lambayeque

Size: $43 \times 22 \mathrm{~cm}$

Material/technique: Slit tapestry, warp cotton 2S, weft camelid fiber $2 \mathrm{~S}$. The threadcount is $11 \mathrm{x}$ 26 per $\mathrm{cm}$.

Further description: anthropomorphic figures with human/bird's head figures and monocrome step fret patterns.

V 9.193 and V 9.294 are from the same textile. 


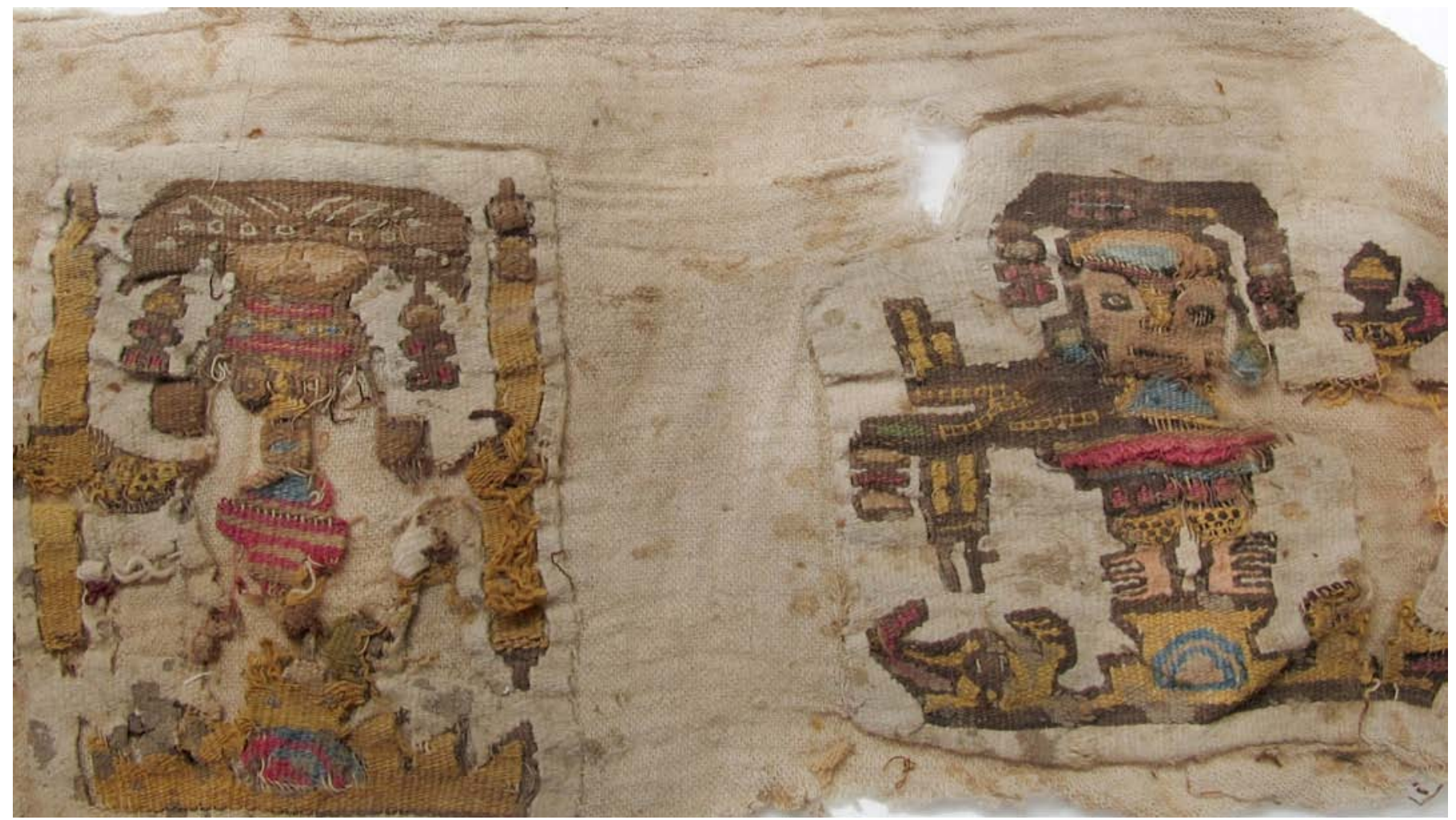

\section{Museum number: V 9.171}

Item: Fragment of a tunic

Style: Lambayeque

Size: $24 \times 58 \mathrm{~cm}$

Material/technique: The fragment is from a tunic.

The foundation material is loosely woven plain weave cotton $\mathrm{S}-$ the warp is paired. The threadcount is 18 (paired) $\times 12$ per $\mathrm{cm}$.

Further description: Patches of slit tapestry (16-14 x 13) are appliqued on a foundation textile. The motifs are "the great lord" (or God) standing on a step fret construction, wearing a feathered headdress and ear spools and carrying staffs in both hands. On the right patch is a stripe of looped wefts on the person's stomack.

The two other patches are similar - and the right (although representing the same) is a very different design.

The patches have cotton warp - the two right are $S$ and the left is $Z$ spun. The wefts are camelid fiber $2 S$ and $2 Z$ cotton.

The 3,5 cm wide sideband is also slit tapestry. Warp $S$ and weft camelid fiber $2 S$ and paired cotton Z. 


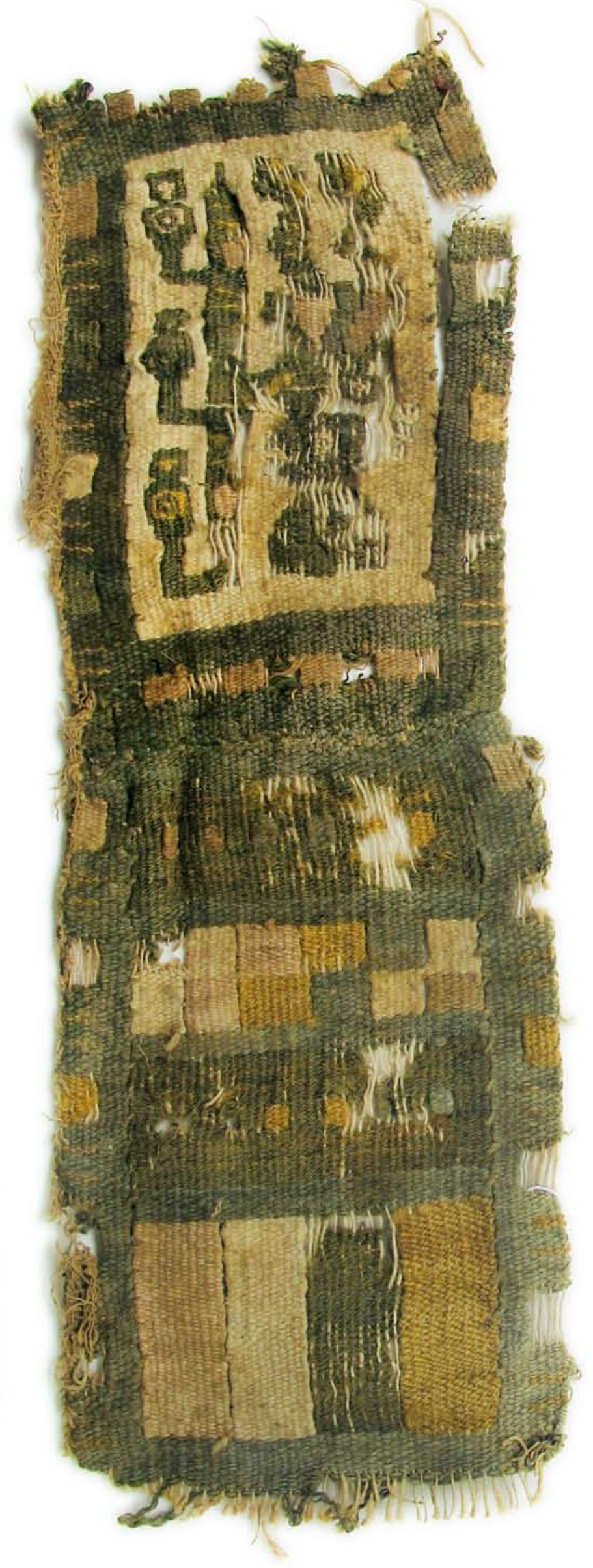

\section{Museum number: V 9.114}

Item: Fragment

Style: Lambayeque

Size: $30 \times 10 \mathrm{~cm}$

Material/technique: slit tapestry, warp cotton $2 \mathrm{~S}$, weft cotton $2 \mathrm{~S}$ and camelid fiber $2 \mathrm{~S}$. The threadcount is $7 \times 20$ per $\mathrm{cm}$. Two fragments of $14,4 \mathrm{~cm}$ are sewn together along the warp selvedge. Along the right weft selvedge is a smal fragment of a loosely woven, plain weave cotton textile, stitched on.

Probably the item is a center stripe from a tunic. 


\section{Museum number: V 9.098}

Item: Fragment of patch

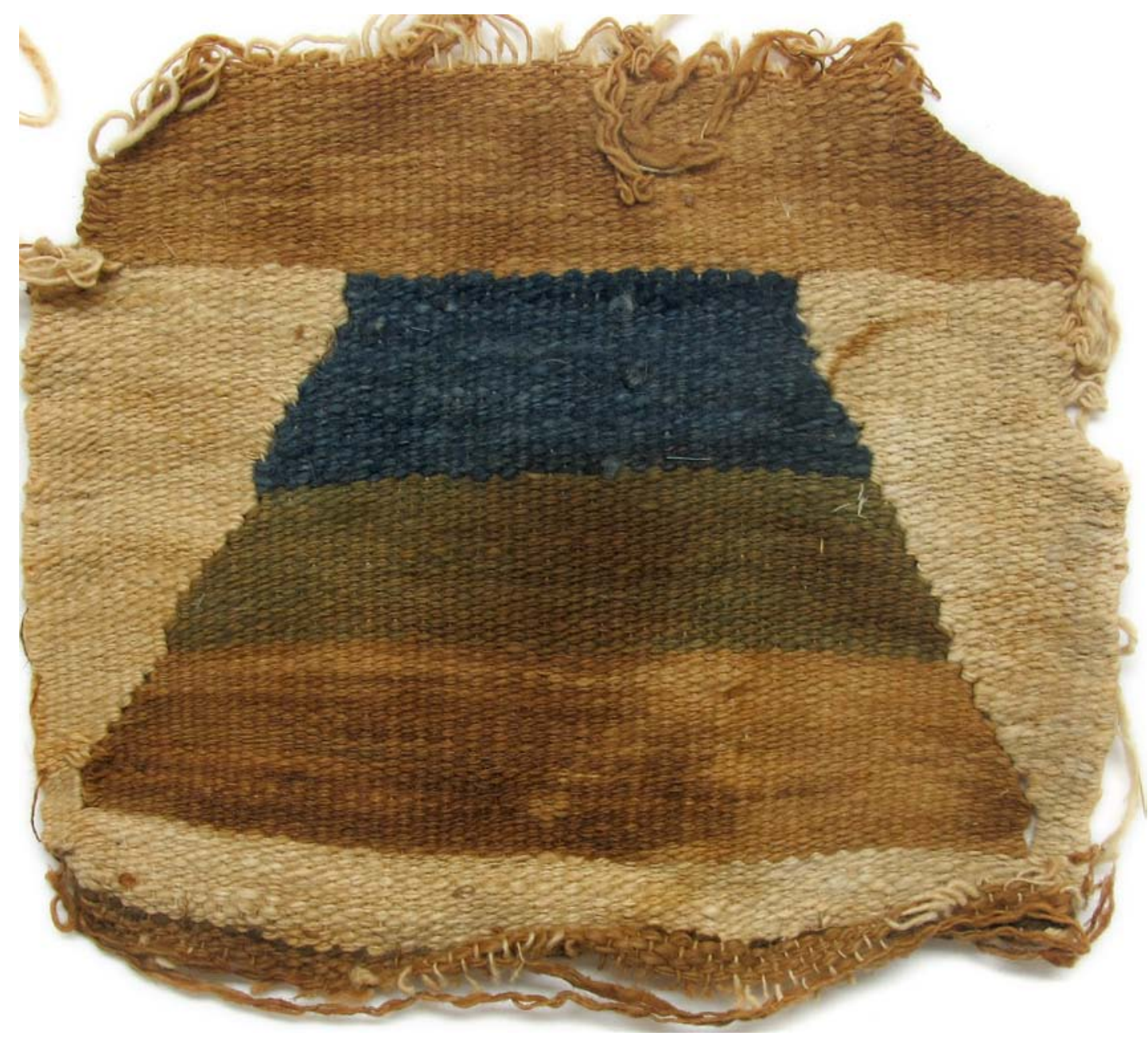

Style: Lambayeque

Size: $13 \times 14 \mathrm{~cm}$

Material/technique: Tapestry with warp cotton $\mathrm{S}$ and weft cotton paired $\mathrm{S}$.

2 side selvedges, with fragments of sewing threads used for attatching it to the foundation textile.

The image is of a pyramid - an abstract power symbol.

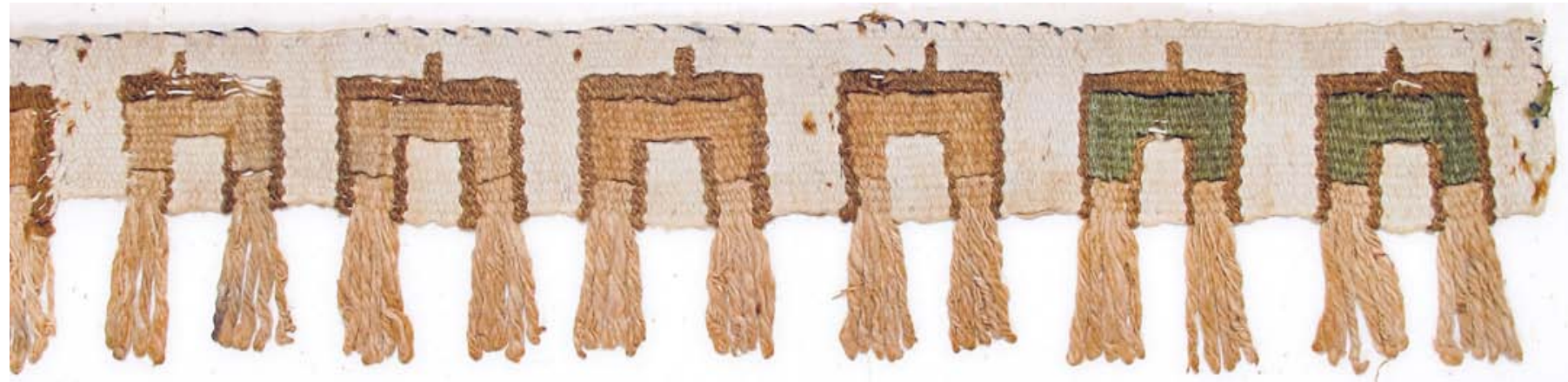

\section{Museum number: V 9.100}

Item: Fragment of a band

Style: Lambayeque

Size: $62 \times 7 \mathrm{~cm}$

Material/technique: Tapestry with weft fringes. Warp: cotton S, weft: cotton $Z$ and camelid fiber $2 \mathrm{~S}$.

The threadcount is $5 \times 30$ per $\mathrm{cm}$. 


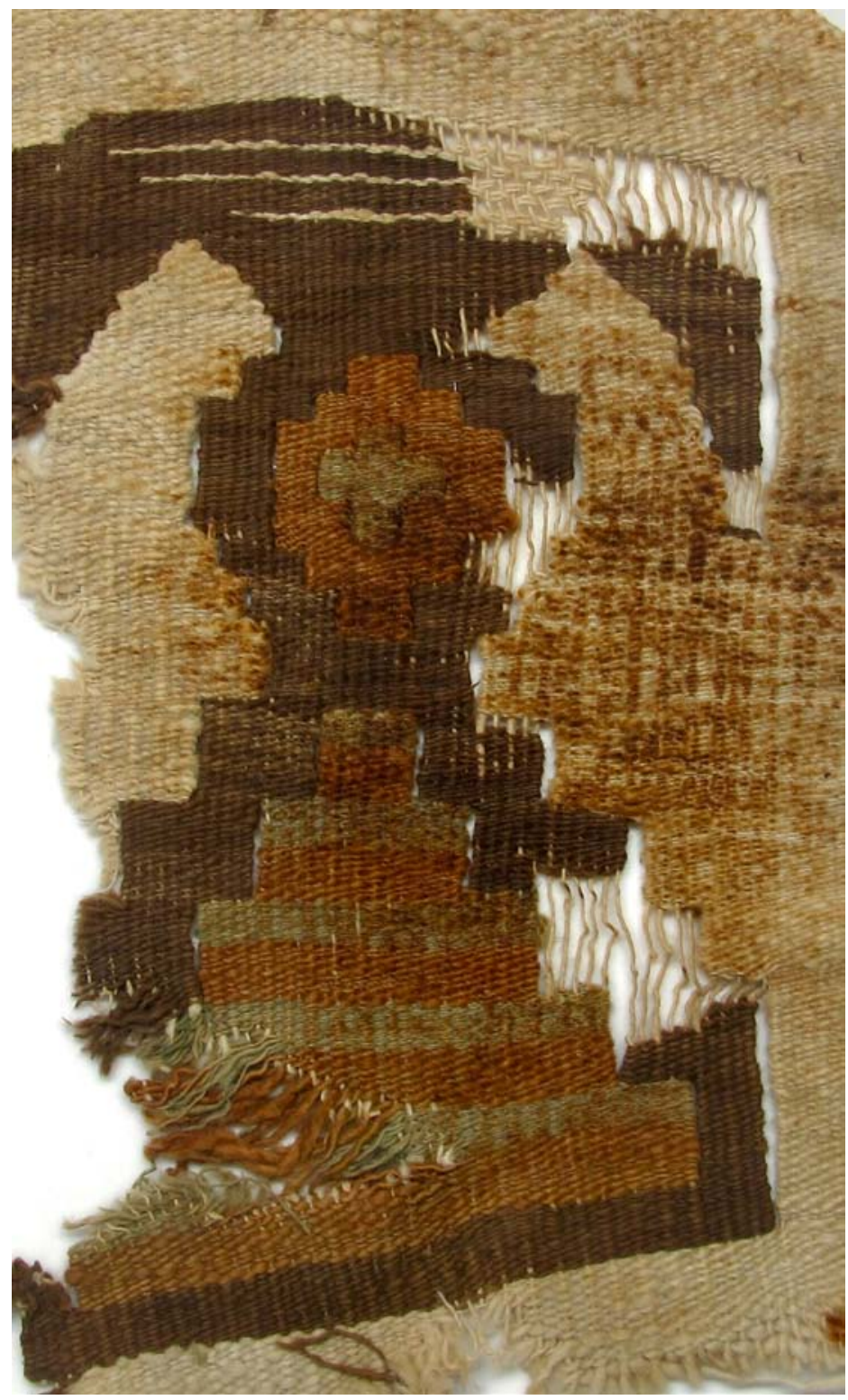

\section{Museum number: V 9.093}

Item: Patch

Style: Lambayeque

Size: $18 \times 12 \mathrm{~cm}$

Material/technique: Tapestry, warp cotton S, weft cotton S, single and paired.

The fragment is probably from a tunic. The image is a status person/god (step fret pyramid with face with crescent headgear as an abstract power symbol). The patch has side selvedges - along one are sewing threads for attatching to the foundation textile.

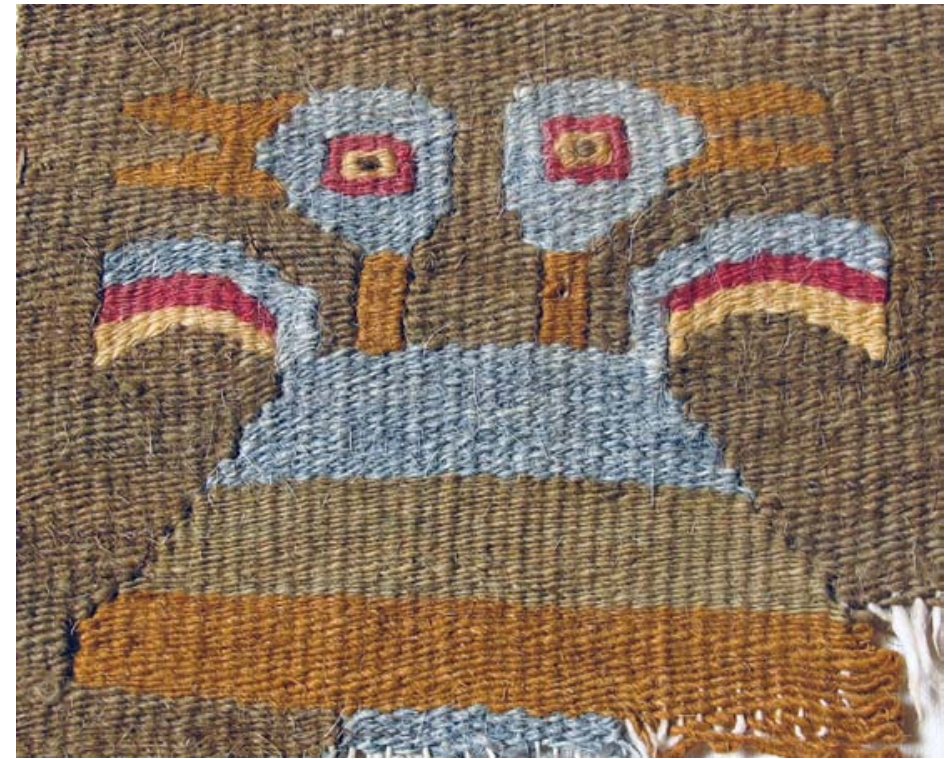

\section{Museum number: V 9.091}

Item: Fragment of patch for tunic Style: Lambayeque Size: $12 \times 12 \mathrm{~cm}$

Material/technique: Tapestry, cotton $S$ warp, camelid fiber $2 S$ weft. The threadcount is $5 \times 34$ per $\mathrm{cm}$. Two side selvedges - no warp selvedges. 


\section{Museum number: V 9.092}

Item: Patch for tunic

Style: Lambayeque

Size: $20 \times 12,5 \mathrm{~cm}$

Material/technique: The patch is in cotton tapestry weaving and has the warp $S$, and the weft $S$ and $Z$. The red spot is camelid fiber 2S.The threadcount is $6 \times 22-32$ per $\mathrm{cm}$.

At both warp ends the patch is cut and bent down with a $0,5 \mathrm{~cm}$ seam. Two side selvedges.

Further description: The patch is probably from a tunic. Pattern is a status person/god (step fret pyramid and face with crescent headgear - an abstract power symbol). The patch has side selvedges - along one are sewing threads for attaching it to the base textile.

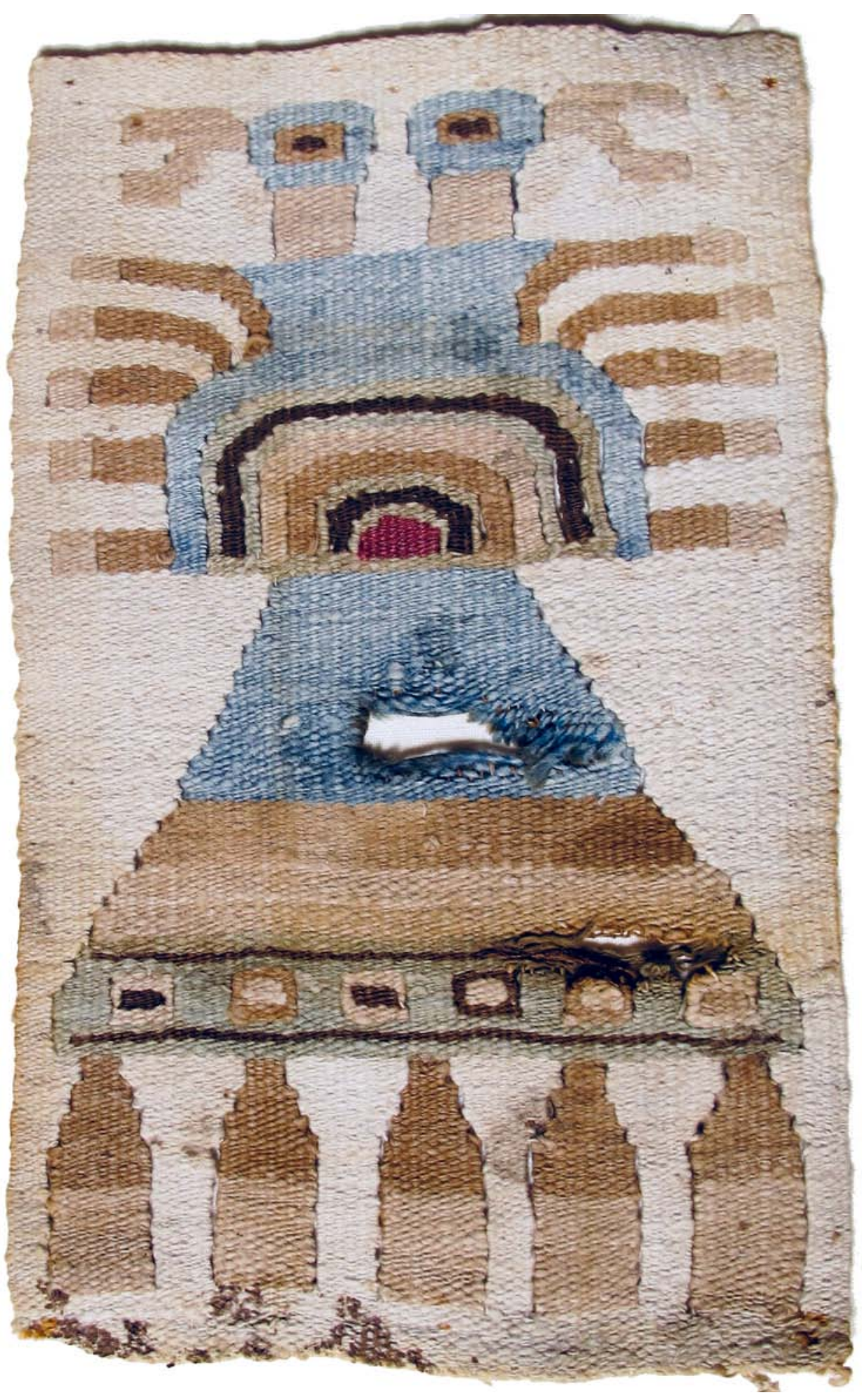




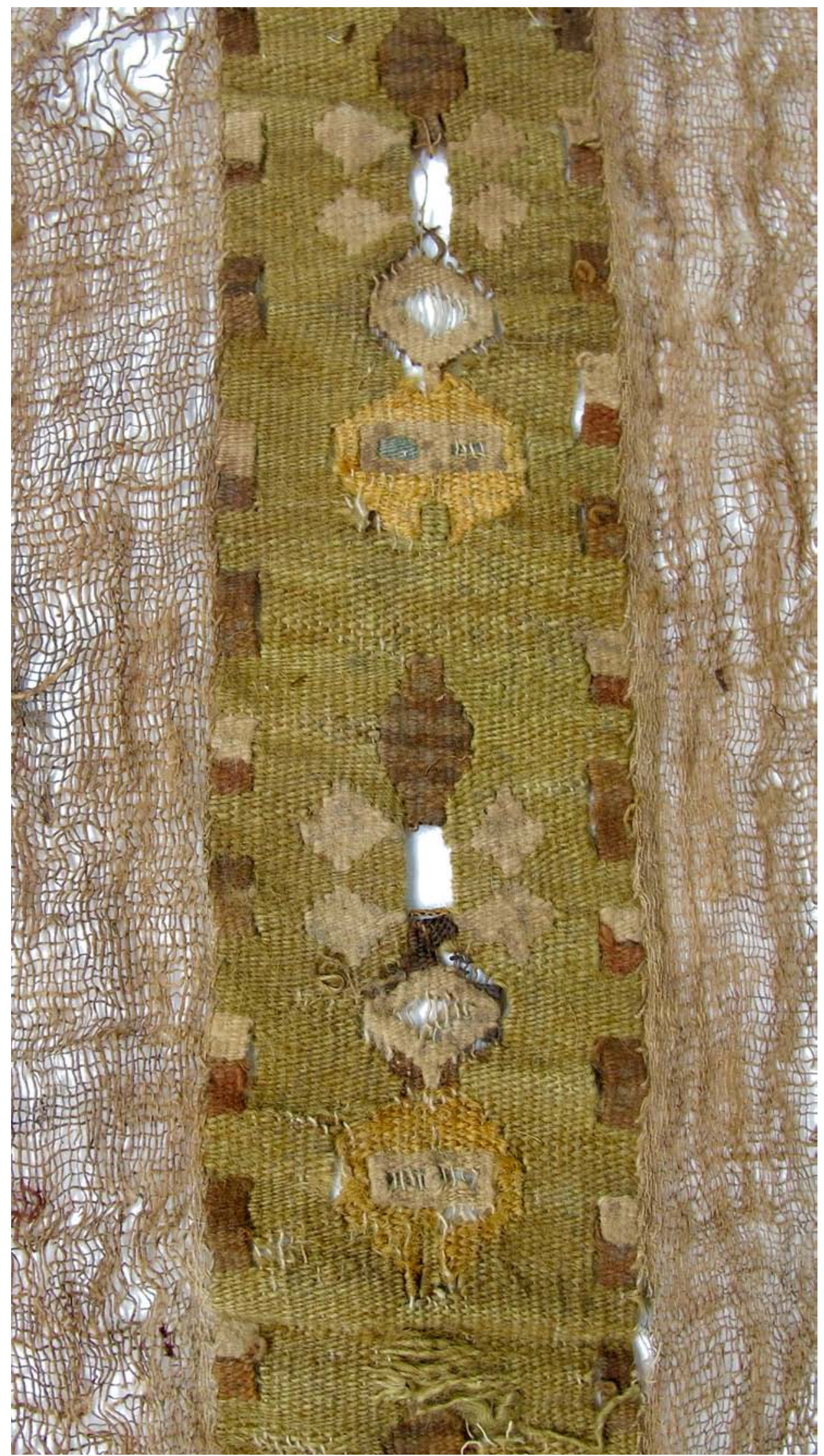

\section{Museum number: V 9.175}

Item: Fragment of tunic

Style: Lambayeque

Size: 54 x $38 \mathrm{~cm}$

Material/ technique: The fragment is from a tunic made in cotton $\mathrm{S}$ loose plain weave. The threadcount is $6 \times 6-8$ per $\mathrm{cm}$. This foundation material of the tunic has 3 different colored warp stripes, and at top a fragment of a horizontal tapestry band with fringe (indicating that it is the back upper part of the tunic). This band is $5 \mathrm{~cm}$ wide, has warp $\mathrm{S}$ cotton, and weft $2 Z$ camelid fiber. The threadcount is 6-7 $\times 20$ per $\mathrm{cm}$. The vertical center band $-6 \mathrm{~cm}$ wide is in slit tapestry with cotton warp $\mathrm{S}$, and camelid fiber weft $2 \mathrm{~S}$. The threadcount is $6-7 \times 20$ per $\mathrm{cm}$. 


\section{Late Intermediate Period (1200 - 1450 AD)}

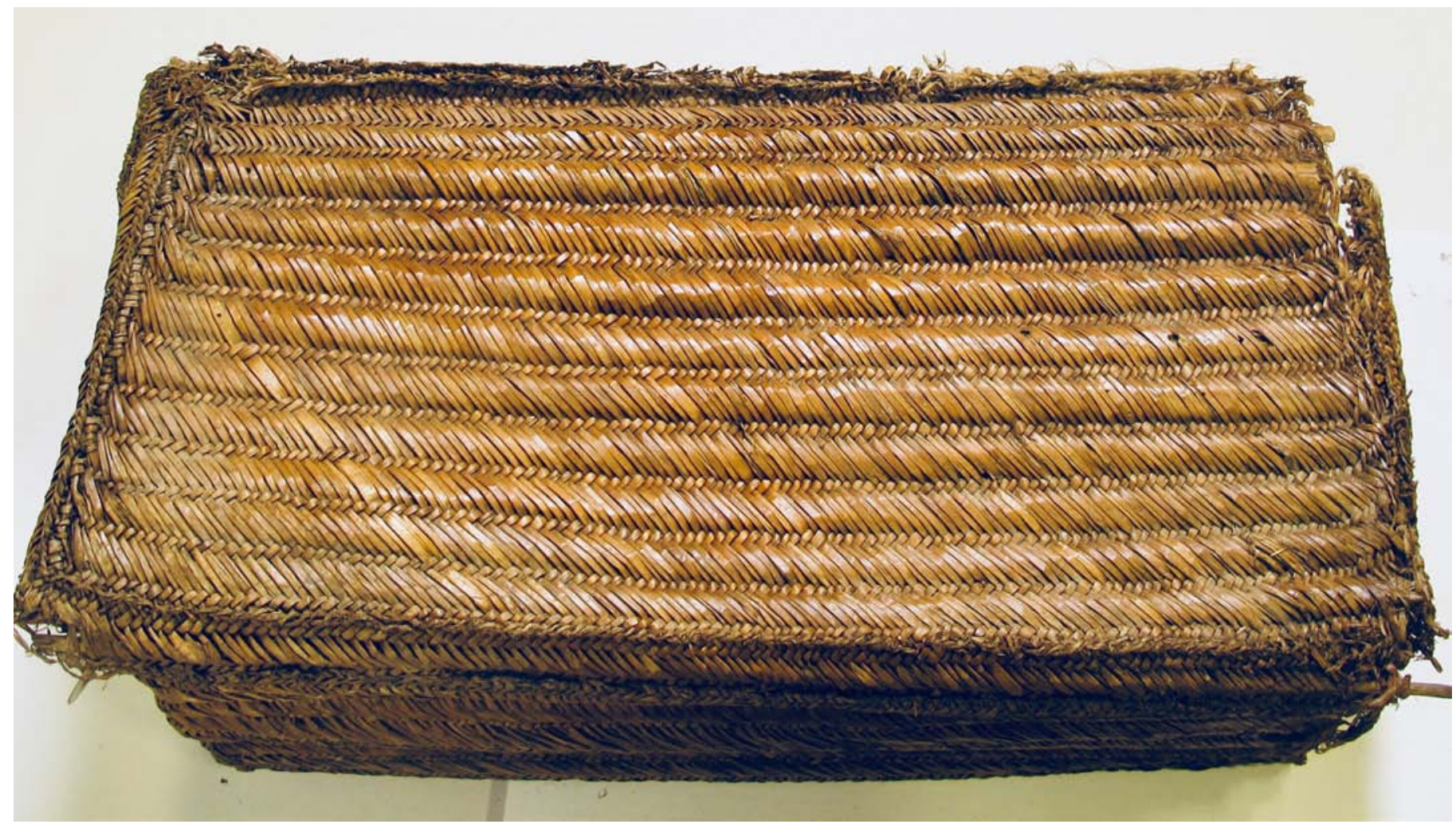

\section{WORK BASKET}

\section{Museum number: V 5.466}

Item: Work basket

Style: Late Intermediate Period, Central Coast/ North Coast

Size: $53 \mathrm{~cm}$ (long) $\times 29 \mathrm{~cm}$ (wide) $\times 23 \mathrm{~cm}$ (height)

Material/technique: The very large workbasket is made of plaited reed. 


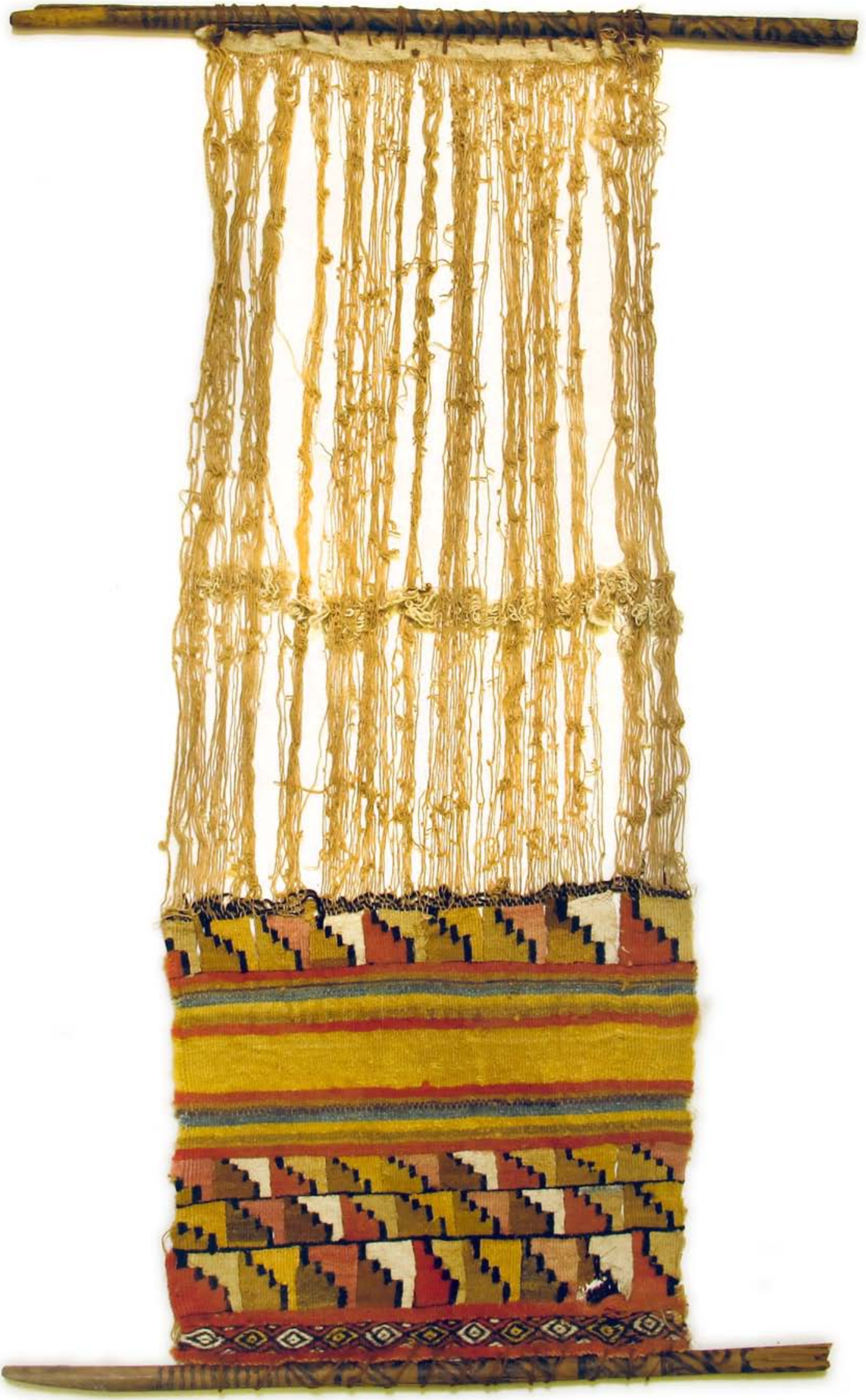

\section{The workbasket contains:}

\section{Museum number: V 10.191 in workbasket}

Item: Loom

Style: Late Intermediate Period, Central coast

Size: Loom sticks $27 \mathrm{~cm}$, weaving $17 \mathrm{~cm}$

Material/technique: Weaving set up on top and bottom beam.

The weaving is slit tapestry. Warp: cotton $S$, weft camelid fiber $2 \mathrm{~S}$. The threadcount is $10 \times 36-40$ per $\mathrm{cm}$.

At bottom is $1 \mathrm{~cm}$ of weft brocade lancée (supplementary weft). At top $1 \mathrm{~cm}$ plain weave. The heddle (cotton 2S) is still in place. 


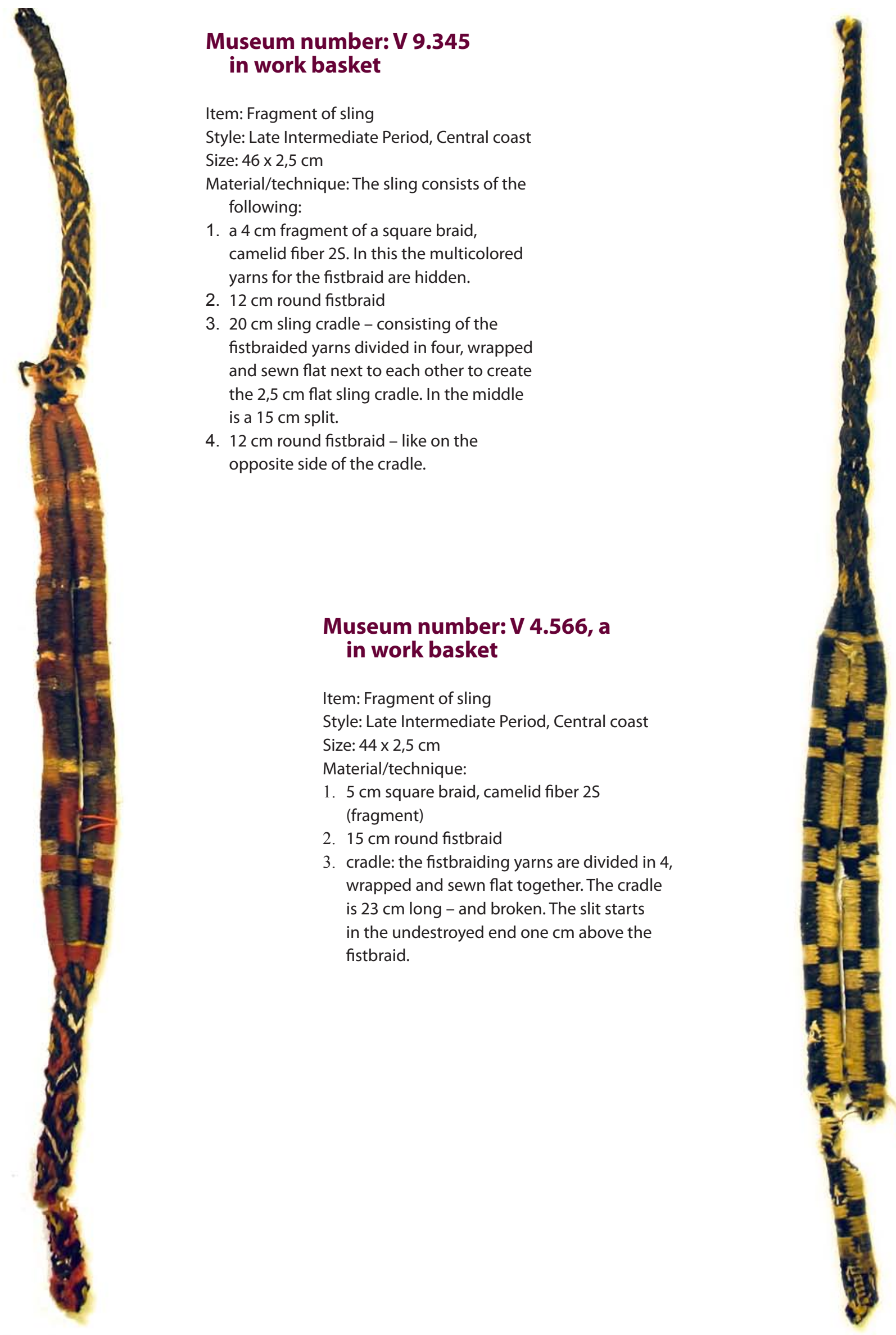



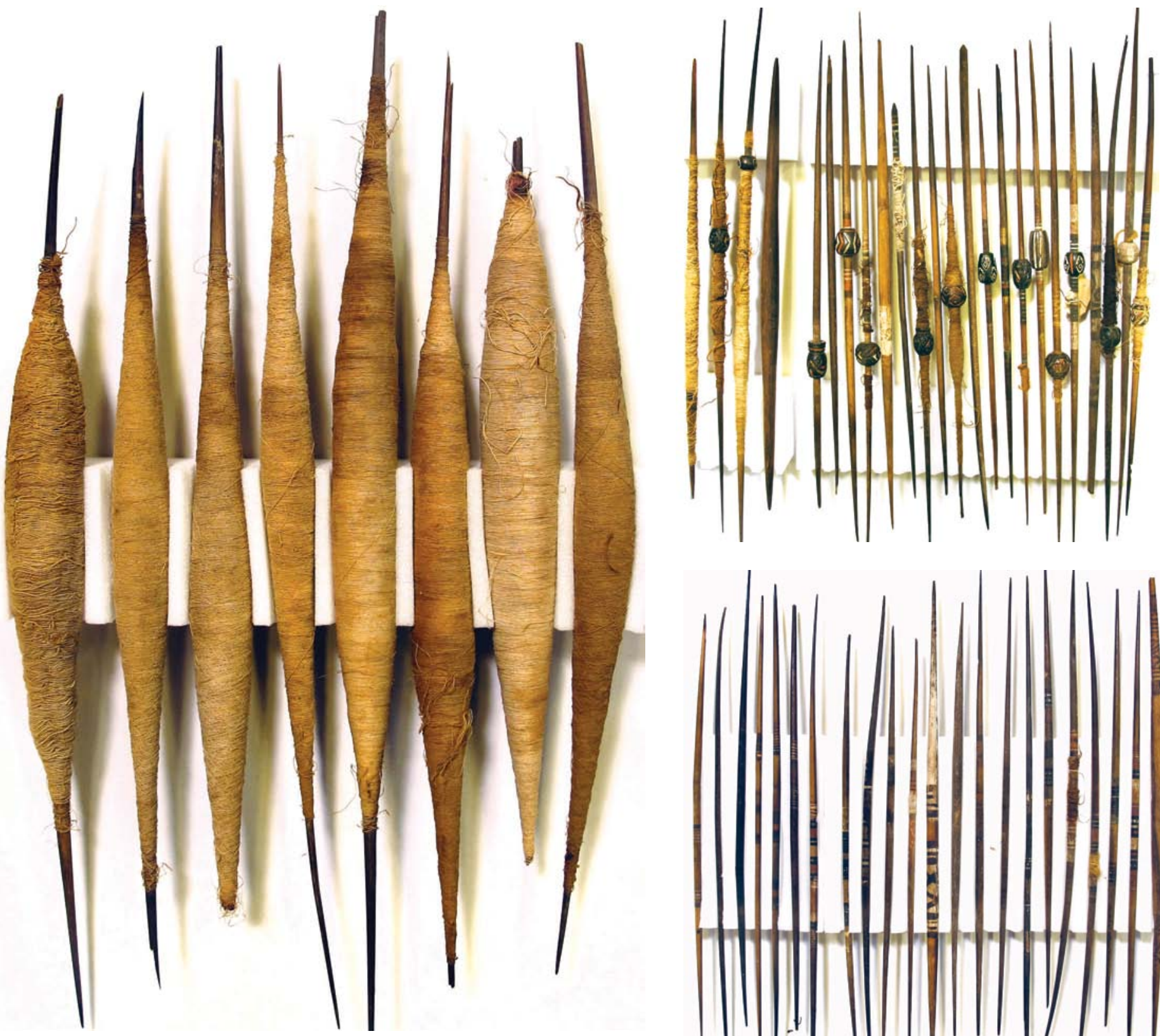

Museum number: V 5.466, b,c,d in work basket

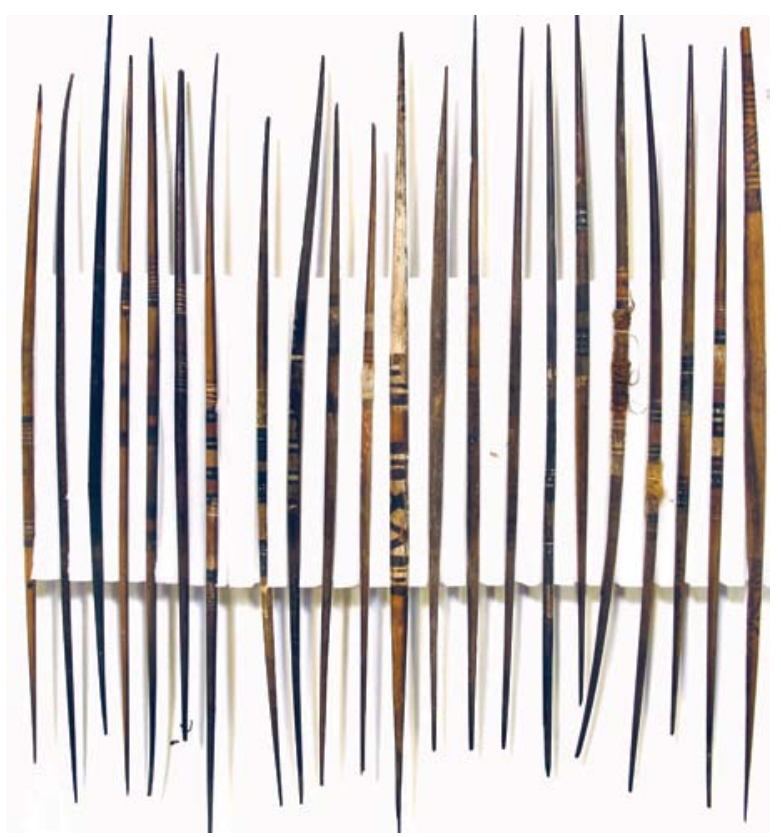

Item: 54 Spindles - 19 with cotton yarn S, and 35 without yarns.

Style: Late Intermediate Period, Central/North Coast

Size: $32-22 \mathrm{~cm}$ long 


\section{Museum number: V 5.466, e in work basket}

Item: Reed bag filled with camelid fiber yarns. Style: Late Intermediate Period, Central coast Size: $27 \times 13 \mathrm{~cm}$

Material/technique: The bag is made in plaited reed and is filled with $2 \mathrm{~S}$ camelid fiber yarns.

\section{Museum number: V 5.466, $\mathrm{f}$ in work basket}

Item: Fragment of a band

Style: North Coast/Central coast

Size: $22 \times 2,5 \mathrm{~cm}$

Material/ technique: Tapestry - cotton Z warp, camelid fiber $S$ weft . The threadcount is $8 \times 45-$ 50 per $\mathrm{cm}$.
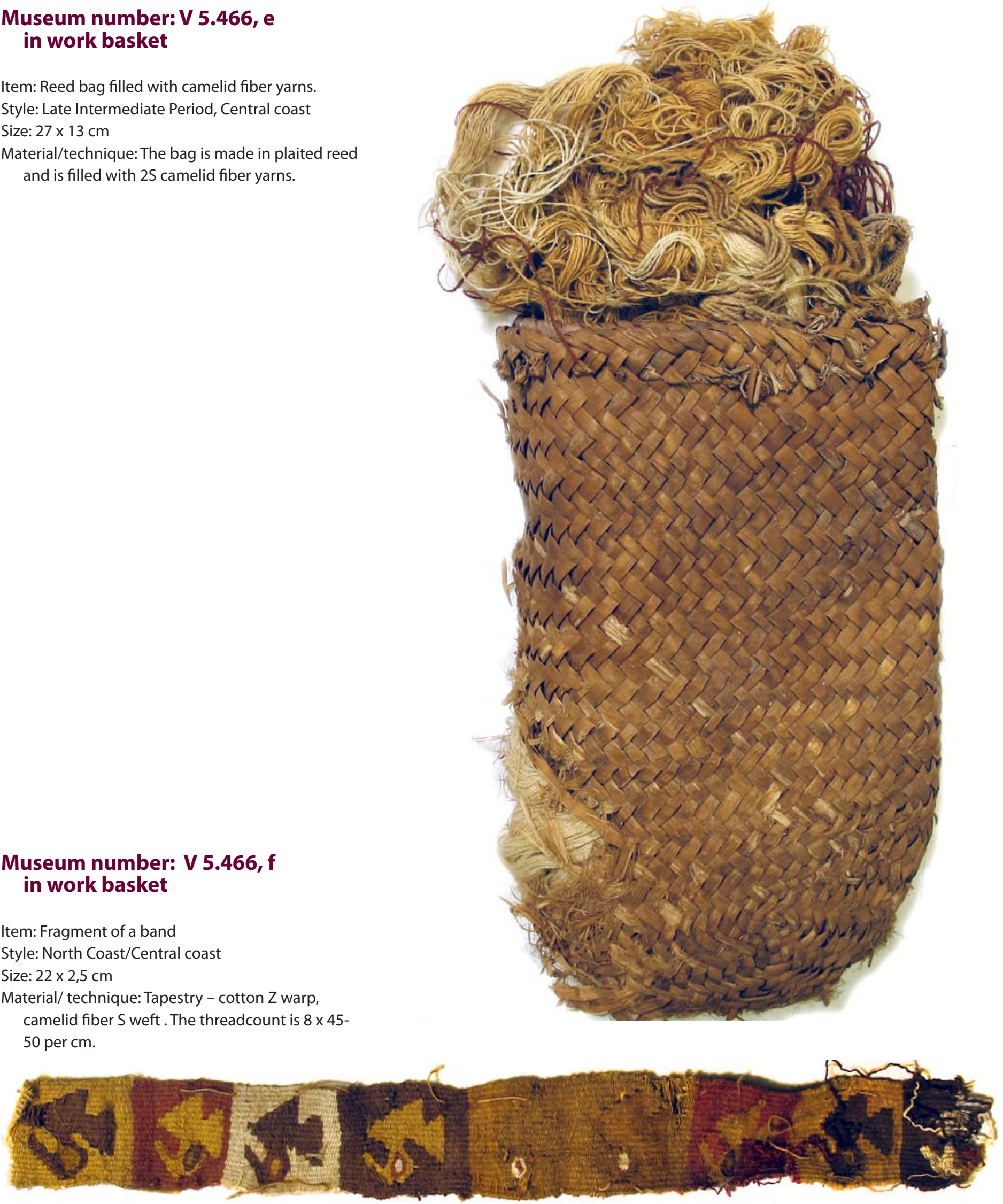


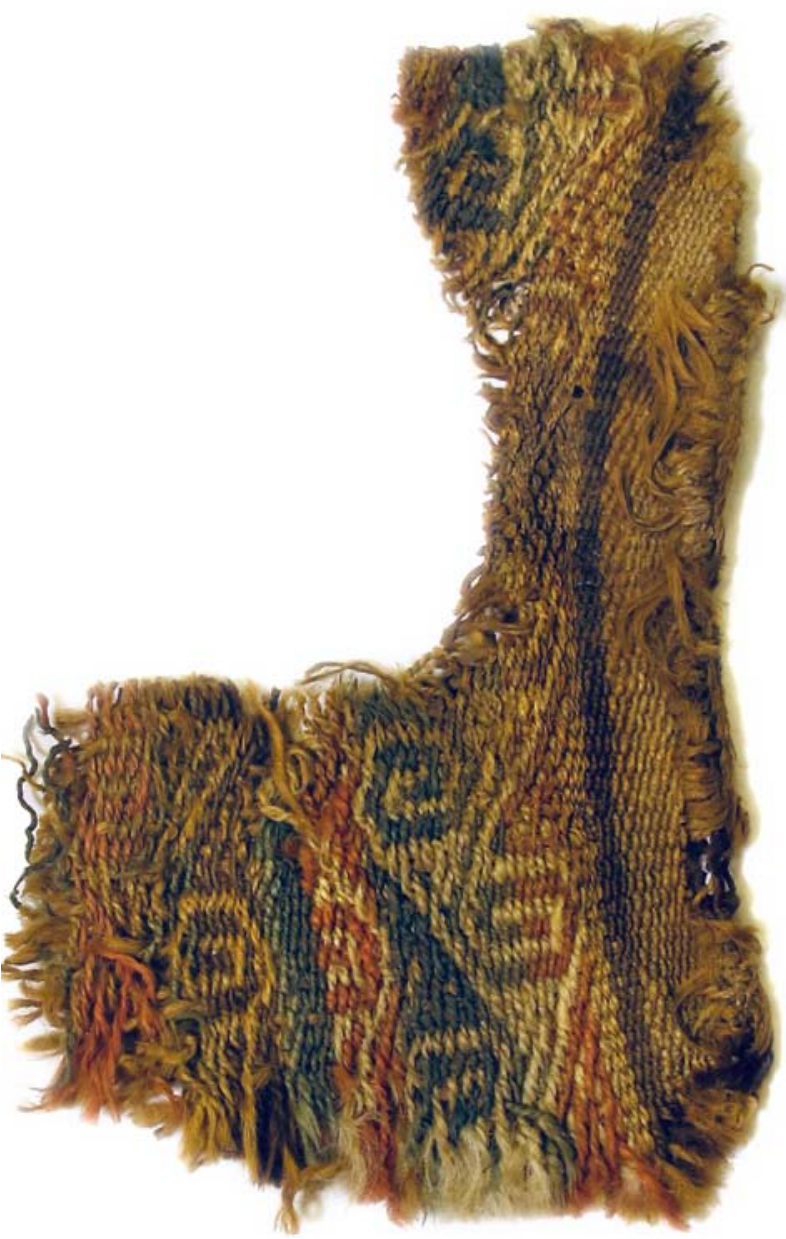

\section{Museum number: V 5.466, g in work basket}

Item: Fragment of weaving

Style: Central Coast

Size: $12 \times 7 \mathrm{~cm}$

Material/technique: complimentary warp patterned, camelid fiber $2 \mathrm{~S}$ weaving fragment. Along one side selvedge it has loopstitch edge embroidery (like neck and arm openings of tunics) so it is probably a fragment of tunic. The threadcount is $10-5$ per $\mathrm{cm}$.

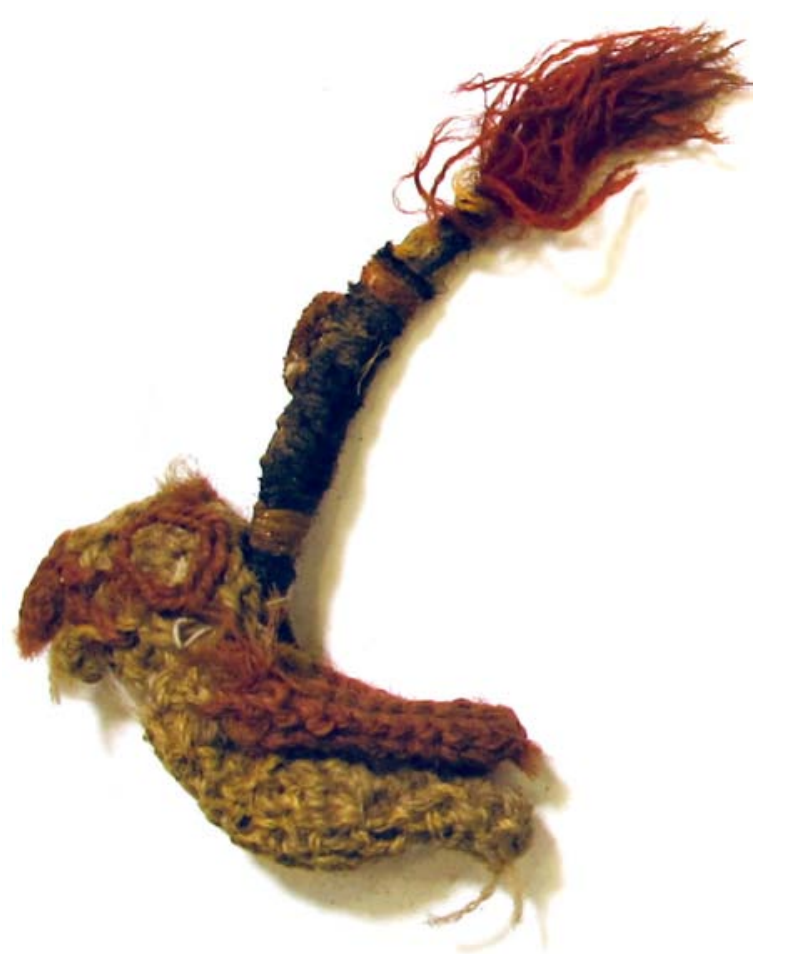

\section{Museum number: $\mathrm{V}$ 4.566, $\mathrm{h}$ in work basket}

Item: Bird ornament

Style: Central coast

Size: bird: $3 \mathrm{~cm}$ x 5 × 1,5 cm; tassel: $6 \mathrm{~cm}$

Material/technique: The bird is made in looping (Wings: cross-knitlooping and body: simple looping). Eyes are embroidered with running stitches. The tassel has a wrapped stem $(4 \mathrm{~cm}$ long). All is in $2 \mathrm{~S}$ camelid fiber.

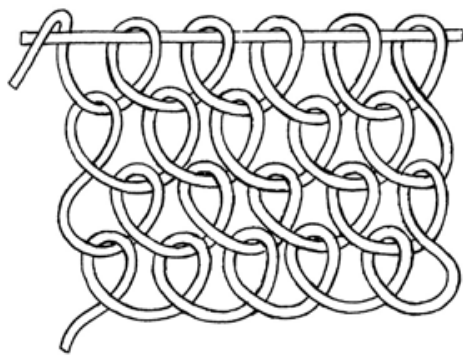

Simple looping

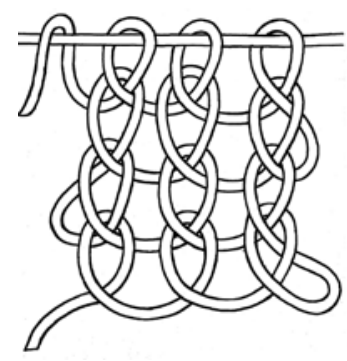

Cross-knit-looping 

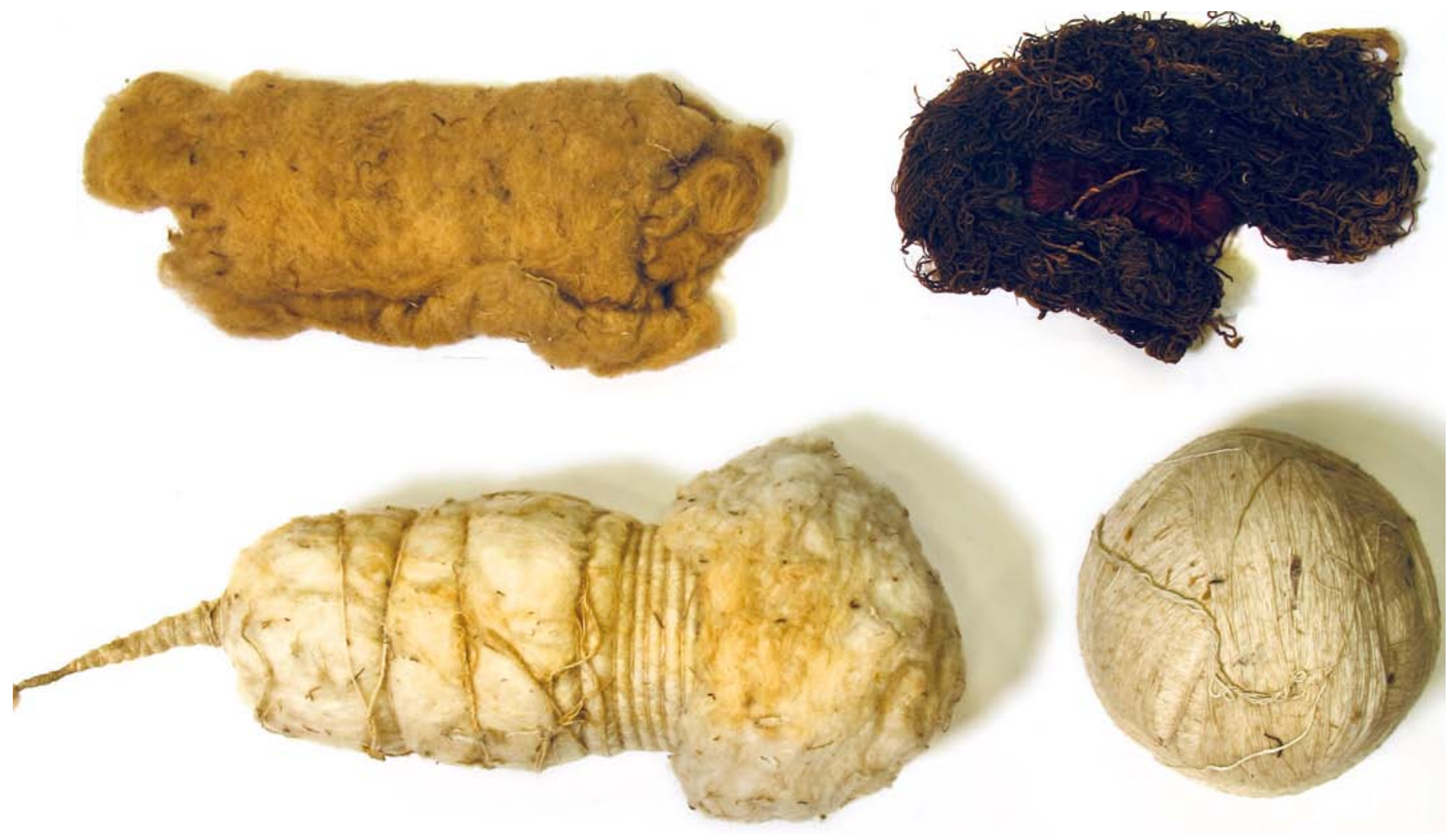

\section{Museum number: V 5.466, i in work basket}

Item: unspun cotton (brown $(21 \mathrm{~cm} \times 9 \mathrm{~cm})$ and white $(\varnothing 28 \mathrm{~cm} \times$ long $29 \mathrm{~cm})$ - ready for spinning. A bowl of white cotton yarn Z spun $(\varnothing 10 \mathrm{~cm})$

Bundle of camelid fiber yarns (red 2S) and brown cotton (S)

\section{Museum number: V 5.466, j in work basket}

Item: Sling

Style: Central coast

Size: $190 \times 1,5 \mathrm{~cm}$

Material/technique:

1. $86 \mathrm{~cm}$ (complete with loop) square 8 strand braid in S plant fiber (probably Fourcraea andina).

2. $6,5 \mathrm{~cm}$ round fistbraid, plantfiber and added 25 camelid fiber yarns.

3. Cradle $15 \mathrm{~cm}$ long (with $14 \mathrm{~cm}$ slit) in wrapped plantfiber yarns divided in four and sewn flat together. The wrapping is plantfiber and cotton $Z$.

4. $15 \mathrm{~cm}$ square 8 strand braid, plantfiber, changing into $60 \mathrm{~cm}$ round 4 braid. This is broken at end.

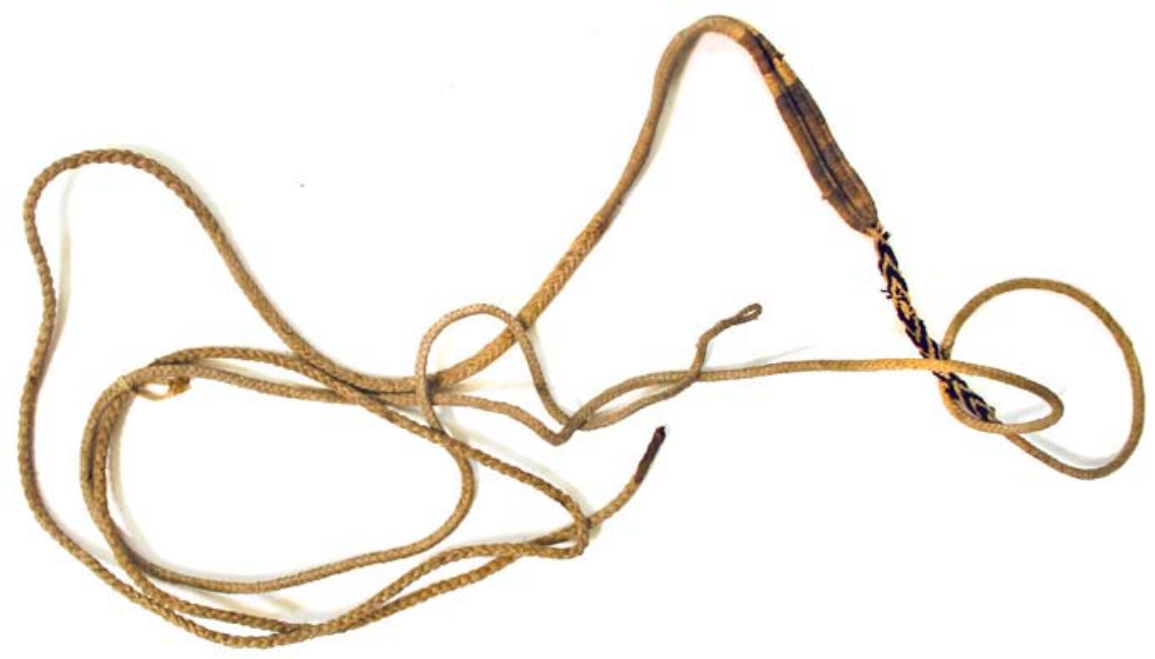



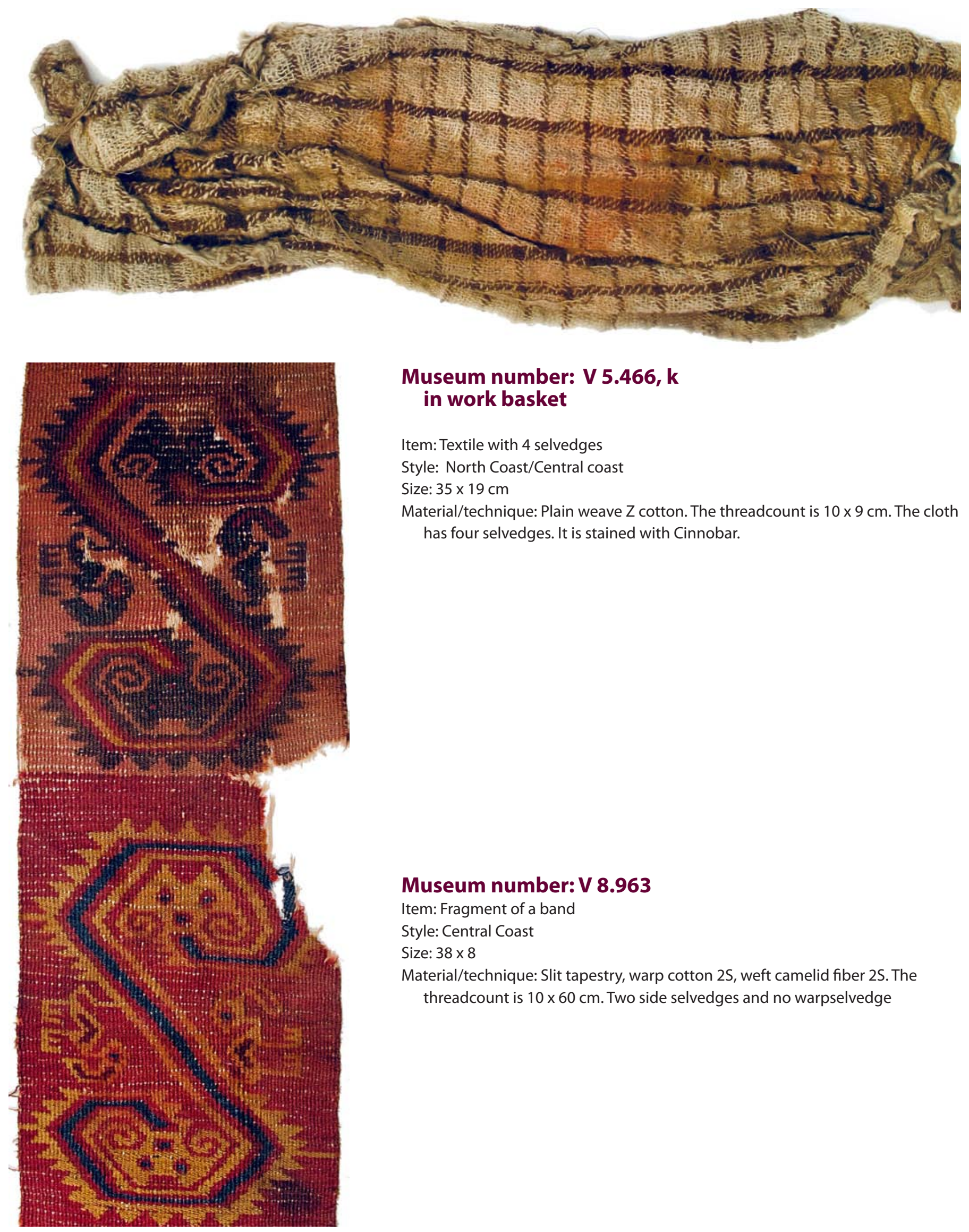

\section{Museum number: V 5.466, k in work basket}

Item: Textile with 4 selvedges

Style: North Coast/Central coast

Size: $35 \times 19 \mathrm{~cm}$

Material/technique: Plain weave $Z$ cotton. The threadcount is $10 \times 9 \mathrm{~cm}$. The cloth has four selvedges. It is stained with Cinnobar.

\section{Museum number: V $\mathbf{8 . 9 6 3}$}

Item: Fragment of a band

Style: Central Coast

Size: $38 \times 8$

Material/technique: Slit tapestry, warp cotton $2 \mathrm{~S}$, weft camelid fiber $2 \mathrm{~S}$. The threadcount is $10 \times 60 \mathrm{~cm}$. Two side selvedges and no warpselvedge 


\section{Museum number: V 8.964}

Item: Fragment probably from a funerary shroud.

Style: Central coast

Size: $63 \times 34 \mathrm{~cm}$

Material/technique: Plain weave in cotton $\mathrm{S}$ for both warp and weft. The threadcount is $22 \times 16 \mathrm{~cm}$. On to this textile is appliqued 9,5-10 $\mathrm{cm}$ squares in tapestry with warp cotton $\mathrm{S}$ and weft camelid fiber $2 \mathrm{~S}$. The squares are placed diagonally on the foundation cloth.

The fragment is part of VA 55944, Wilhelm Gretzer collection, Berlin.

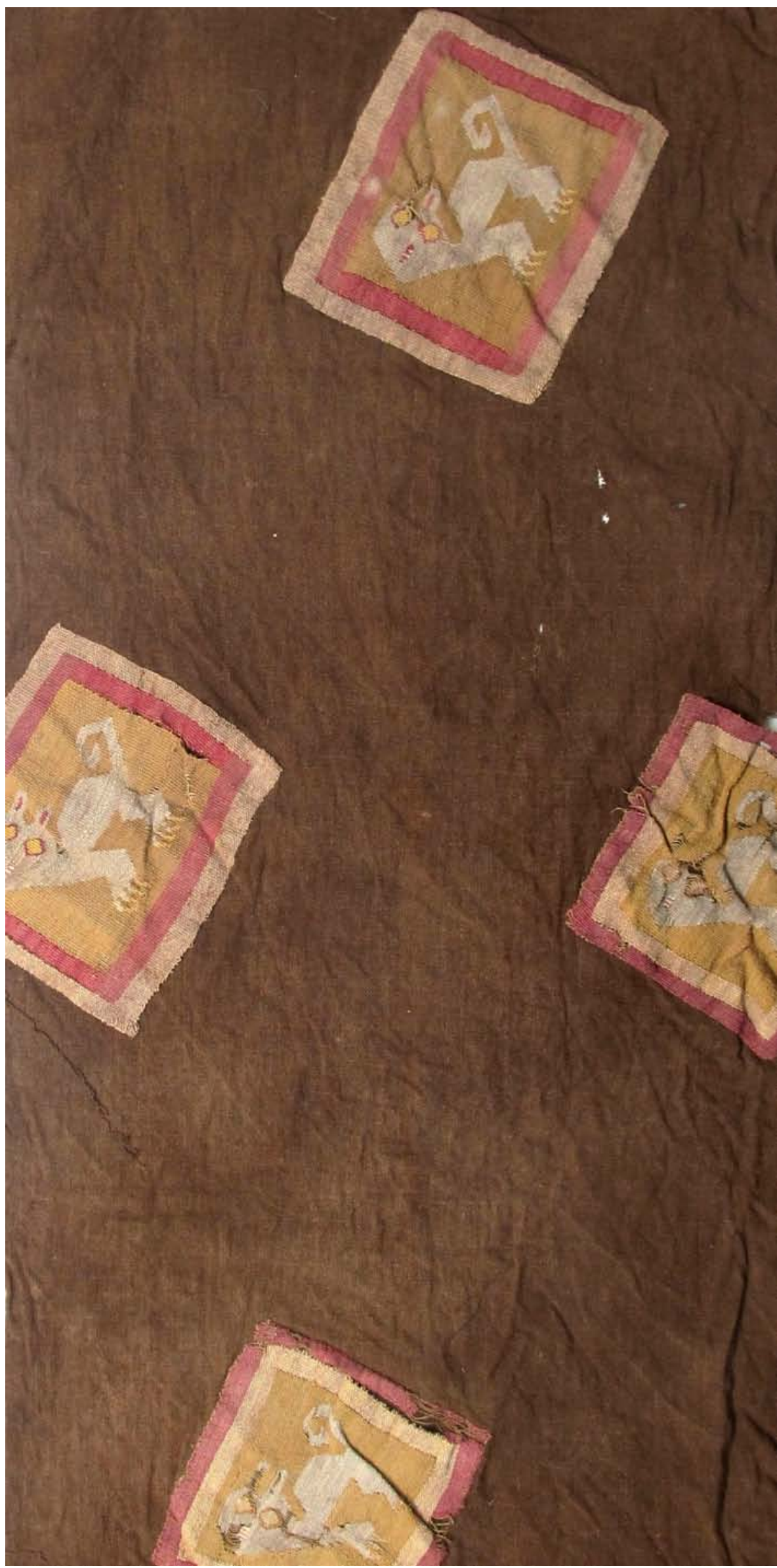



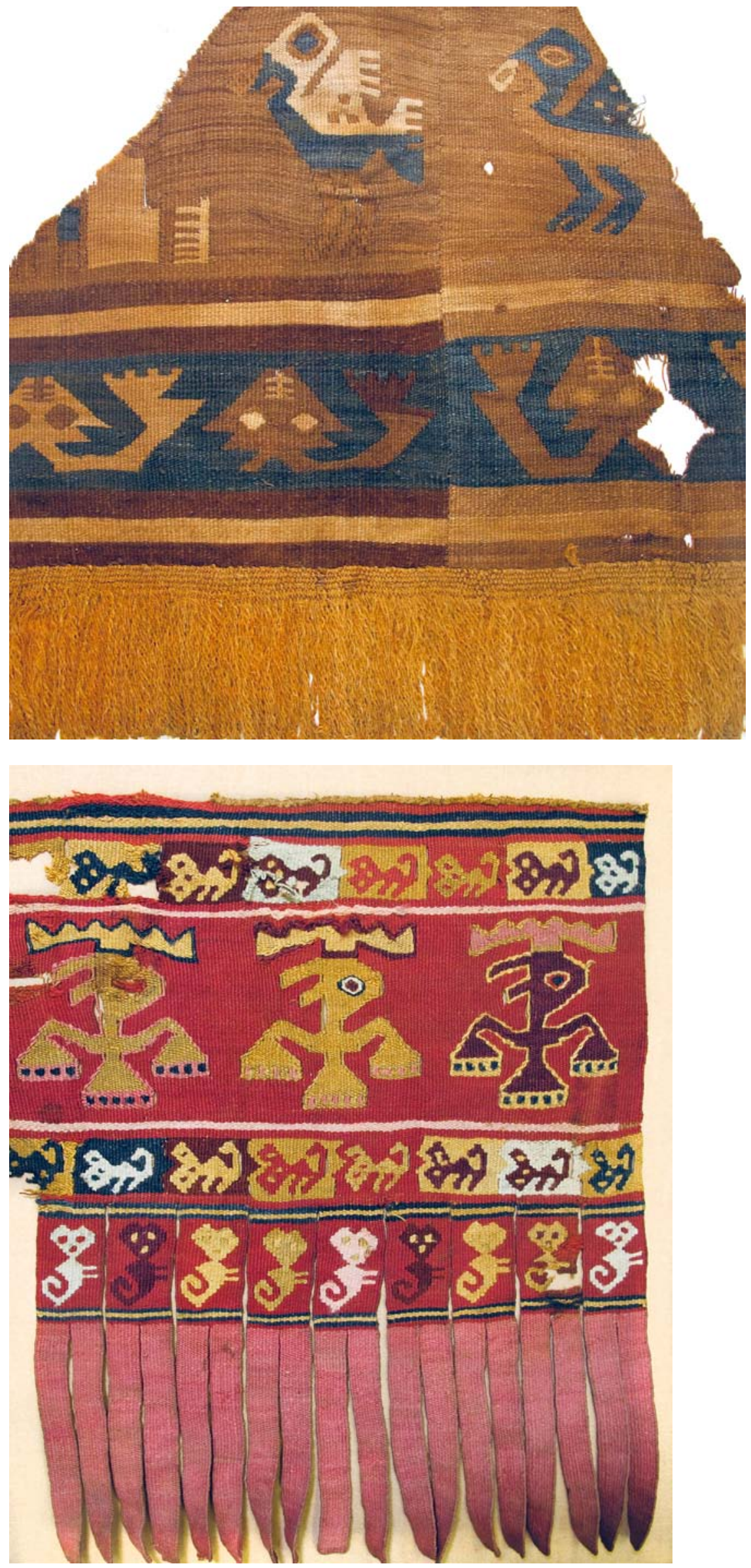

\section{Museum number: V 8.965}

Item: Fragment

Style: Central coast, Ychsma

Size: $23 \times 24 \mathrm{~cm}$

Material/technique: Two panels sewn together and with a $5 \mathrm{~cm}$ wide looped weft fringe at bottom. Warp selvedge at bottom (by fringe). The technique is slit tapestry, warp $2 \mathrm{~S}$ cotton, weft $2 \mathrm{~S}$ camelid fiber. The threadcount is $10 \times 60$ per $\mathrm{cm}$. Probably the textile is the bottom of a tunic.

\section{Museum number: V 8.971}

Item: Fragment

Style: Central coast

Size: $29 \times 29 \mathrm{~cm}$

Material/technique: Slit tapestry with warp cotton $2 \mathrm{~S}$ and weft camelid fiber $2 \mathrm{~S}$. The threadcount is $8 \times 28 \mathrm{~cm}$. The fragment has at bottom woven fringes $(9,5 \times 1 \mathrm{~cm})$. And above that $4,5 \mathrm{~cm}$ slits ( $2 \mathrm{~cm}$ wide) - each being the width of two woven fringes.

Warp-selvedge at top and bottom, weft selvedge right side (when fringes down). 


\section{Museum number: V 8.976}

Item: Fragment

Style: Central coast/ north coast

Size: $63 \times 24 \mathrm{~cm}$

Material/technique: Discontinuous warp and weft in cotton Z, S, paired Z (in weft) and $2 \mathrm{~S}$ - seemingly at random. The fragment has one warp selvedge and two side selvedges. Both warps and wefts are interlocked in each other.

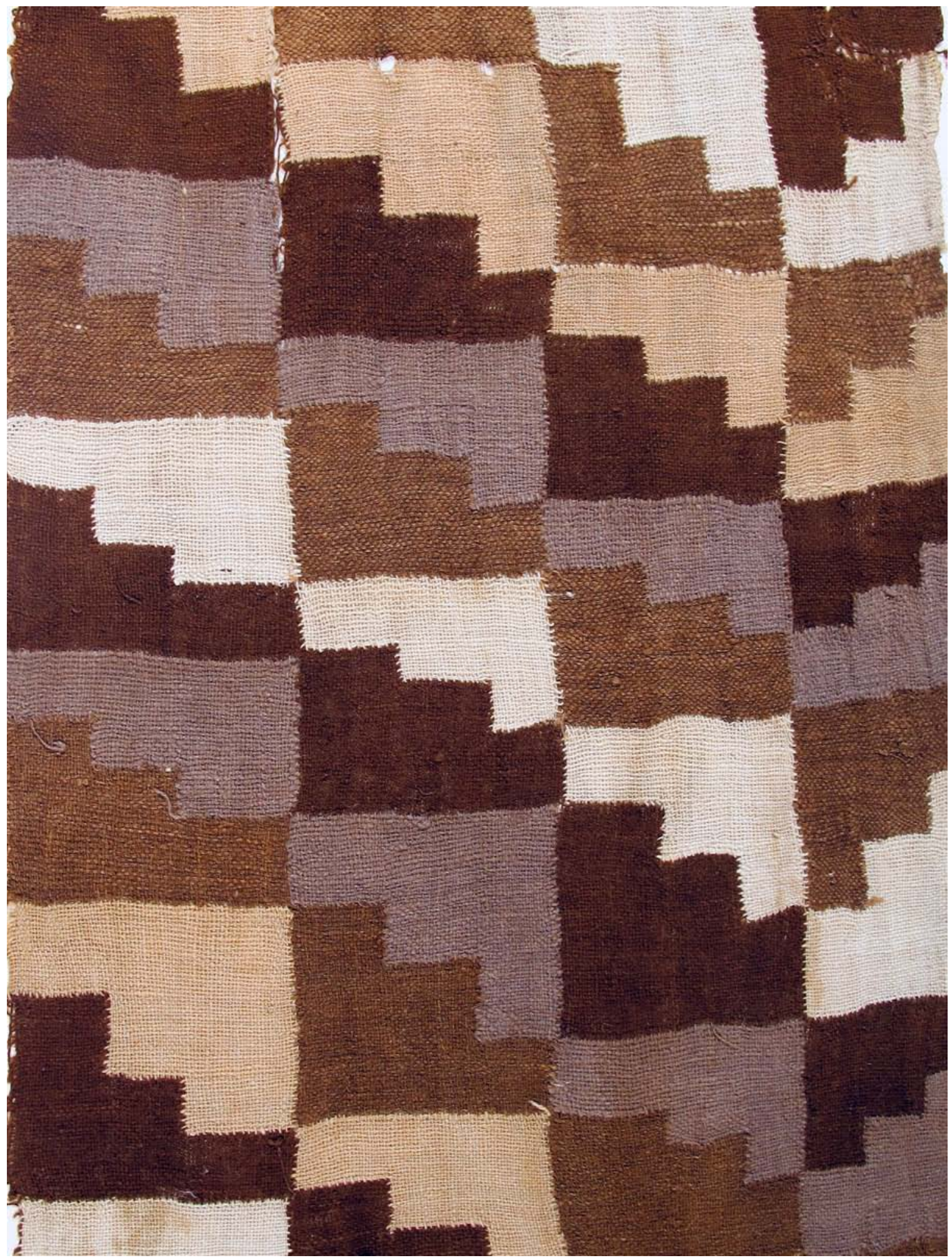




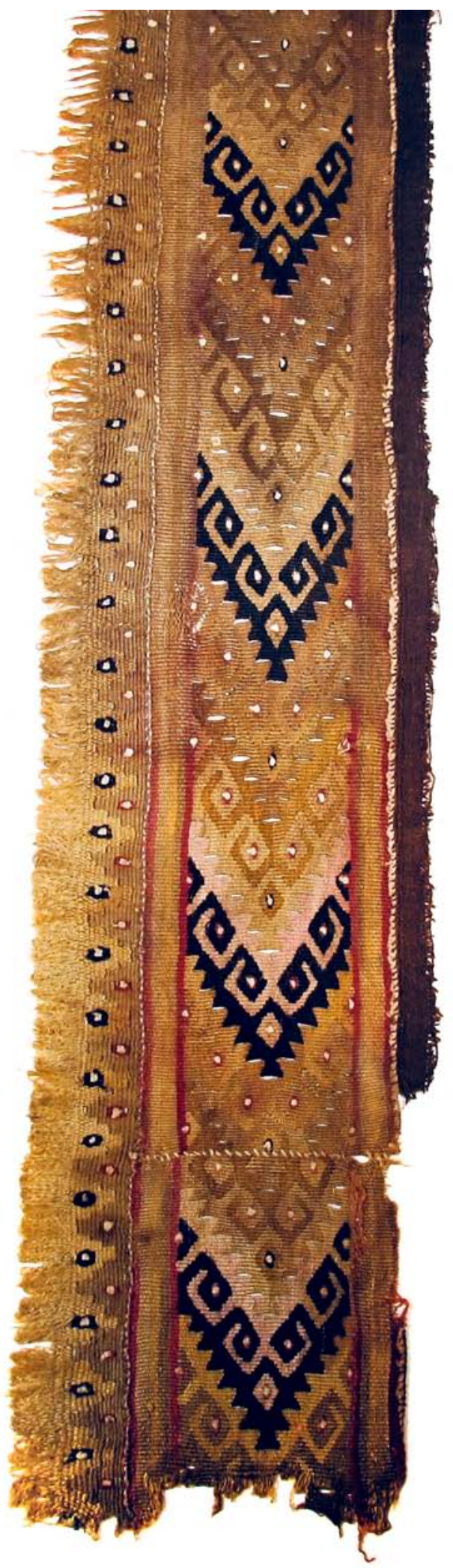

\section{Museum number: V $\mathbf{8 . 9 7 7}$}

Item: Fragment

Style: Central coast, Ychsma

Size: $12,5 \times 52 \mathrm{~cm}$

Material/technique: The textile is probably the lower part of a tunic.

At bottom: 3,5 cm looped weft-fringe with tapestry. This band has warp along the center band.

Above: $7,5 \mathrm{~cm}$ wide slit tapestry band. Consisting of two panels. The warp is on the short side

At top are fragments of plain weave cotton.

\section{Museum number: V $\mathbf{8 . 9 8 4}$}

Item: Fragment from tunic.

Style: Central coast, Chancay

Size: $26 \times 13 \mathrm{~cm}$

Material/technique: The textile is probably from the bottom edge of a tunic. The fragment consists of :

1. A weft faced plain weave band with cut weft fringe. Camelid fiber $2 S$, woven 1,5 $\mathrm{cm}$, the rest loose wefts. The threadcount is $7 \times 20$ per $\mathrm{cm}$.

2. A brocaded band $6 \mathrm{~cm}$ wide with warp and weft in 25 camelid fiber. The threadcount is $9 \times 40$ per $\mathrm{cm}$.

3. Stitched to the band are fragments of a plain weave cotton textile with warp S, weft $Z$ and a threadcount of $8 \times 14$ per $\mathrm{cm}$.

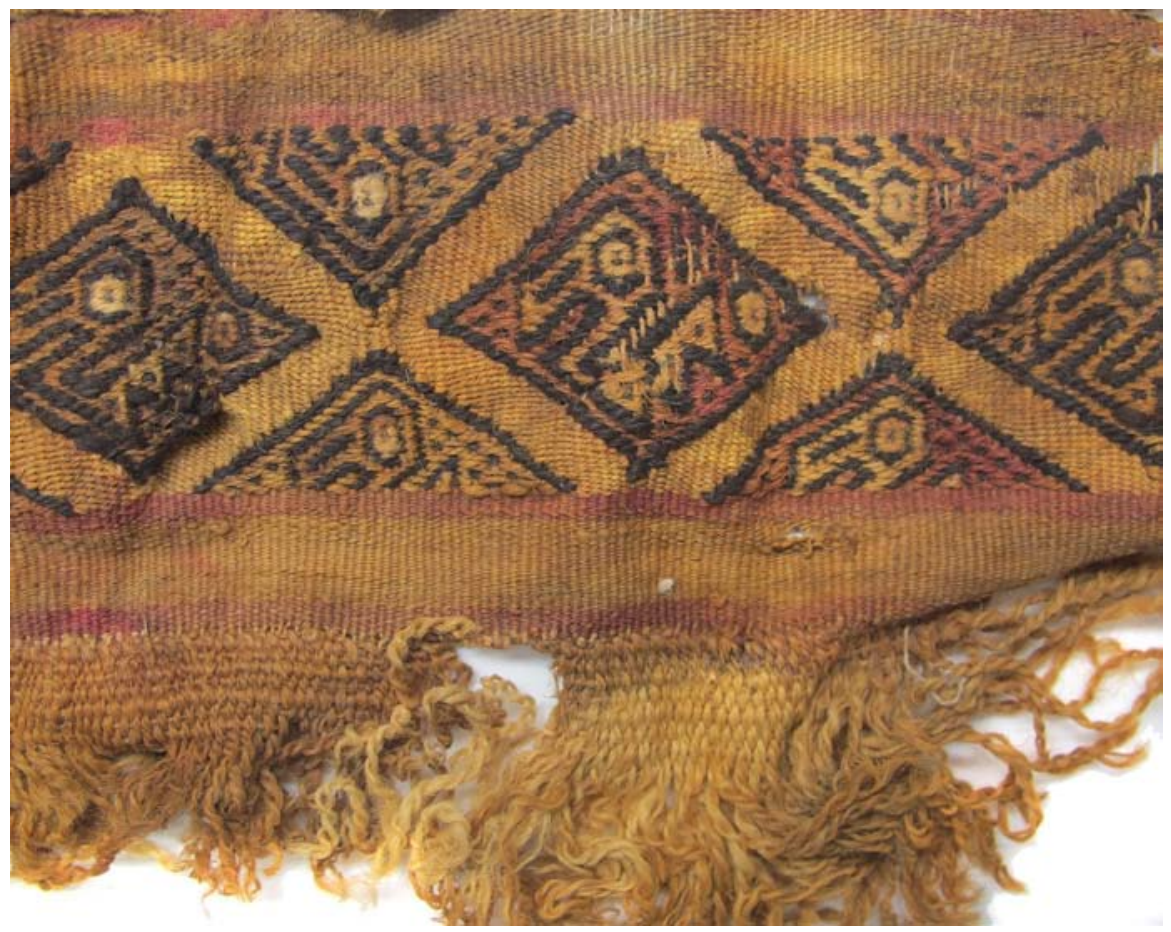




\section{Museum number: V 8.985}

Item: Fragment

Style: Central coast

Size: 30,5 x 19,5 cm

Material/technique: Textile in slit tapestry. The warp is $2 \mathrm{~S}$ cotton (twined from two colors: tan and white). The weft is camelid fiber $2 \mathrm{~S}$. The threadcount is $10 \mathrm{x}$ 40 per $\mathrm{cm}$.

The fragment consists of 3 bands (each $6 \mathrm{~cm}$ wide) stitched together (with $2 \mathrm{~S}$ cotton yarn). The bands have selvedges on all sides. On two of the bands the warp selvedges are still present, and so the measurement stated above is probably the original complete textile. Top and bottom edge is embroidered (cotton 2S, three strands) - top cross knit loop stitch edging, and at bottom with a $0,5 \mathrm{~cm}$ stripe of stem stitches.

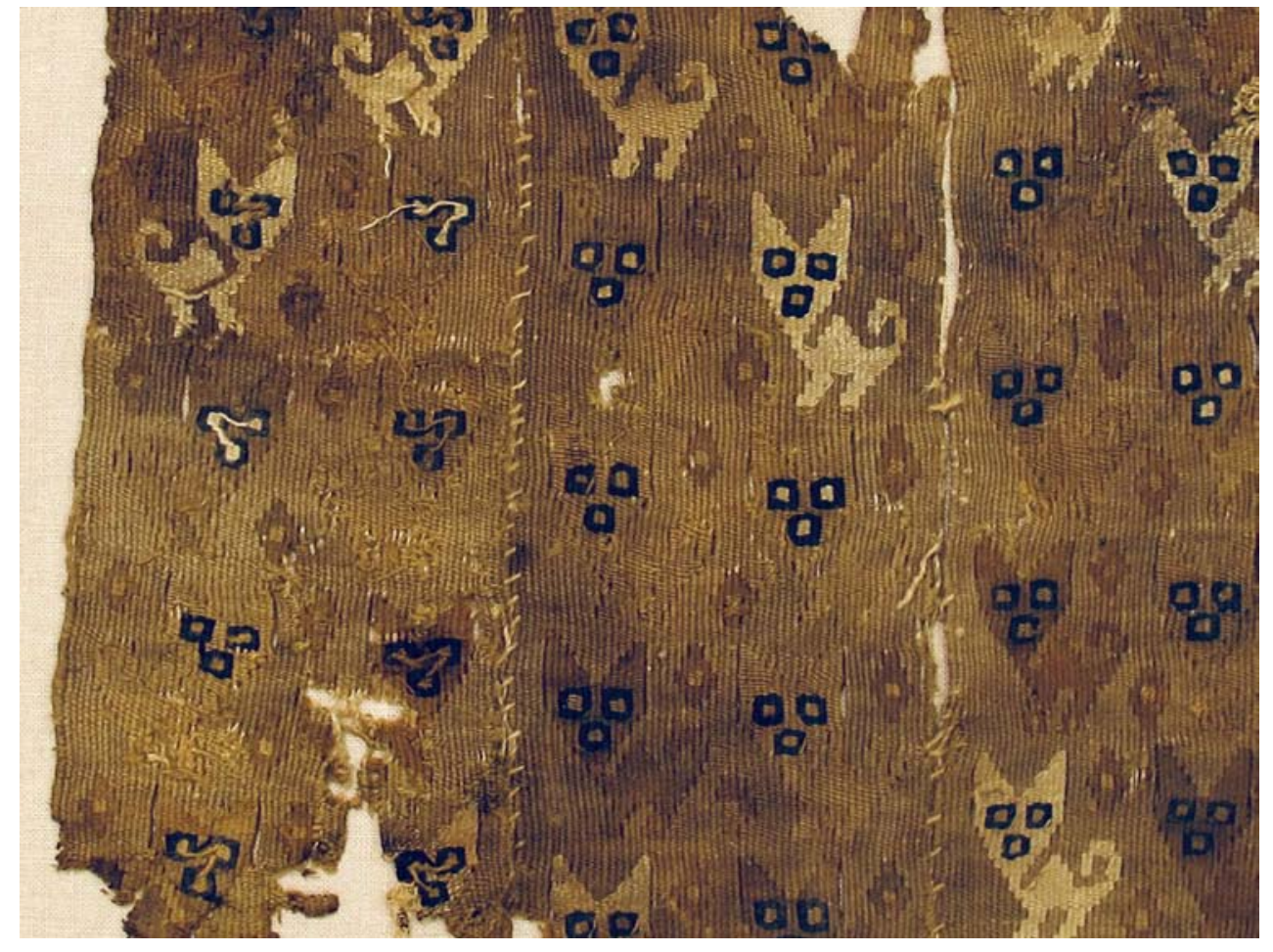

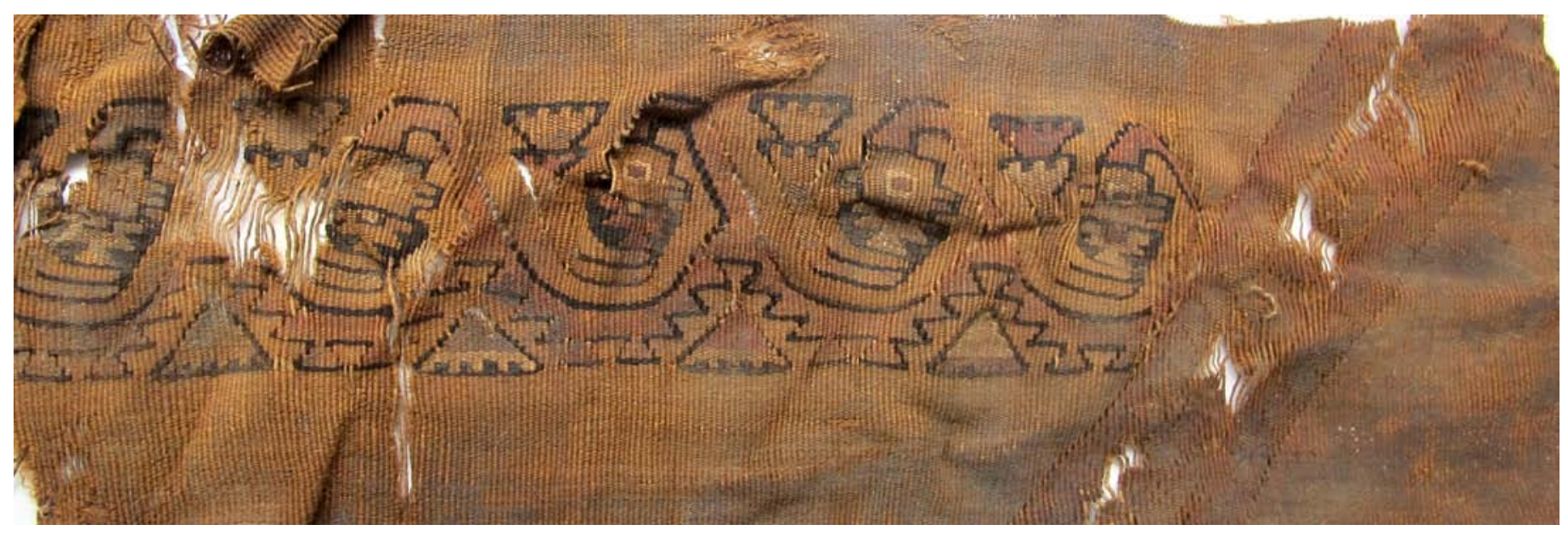

\section{Museum number: V 9.007}

Item: Fragment

Style: Central coast

Size: $14 \times 27 \mathrm{~cm}$

Material/technique: The technique is tapestry with the warp in 35 cotton and the weft $2 \mathrm{~S}$ camelid fiber. The threadcount is $12 \times 70$ per $\mathrm{cm}$. 

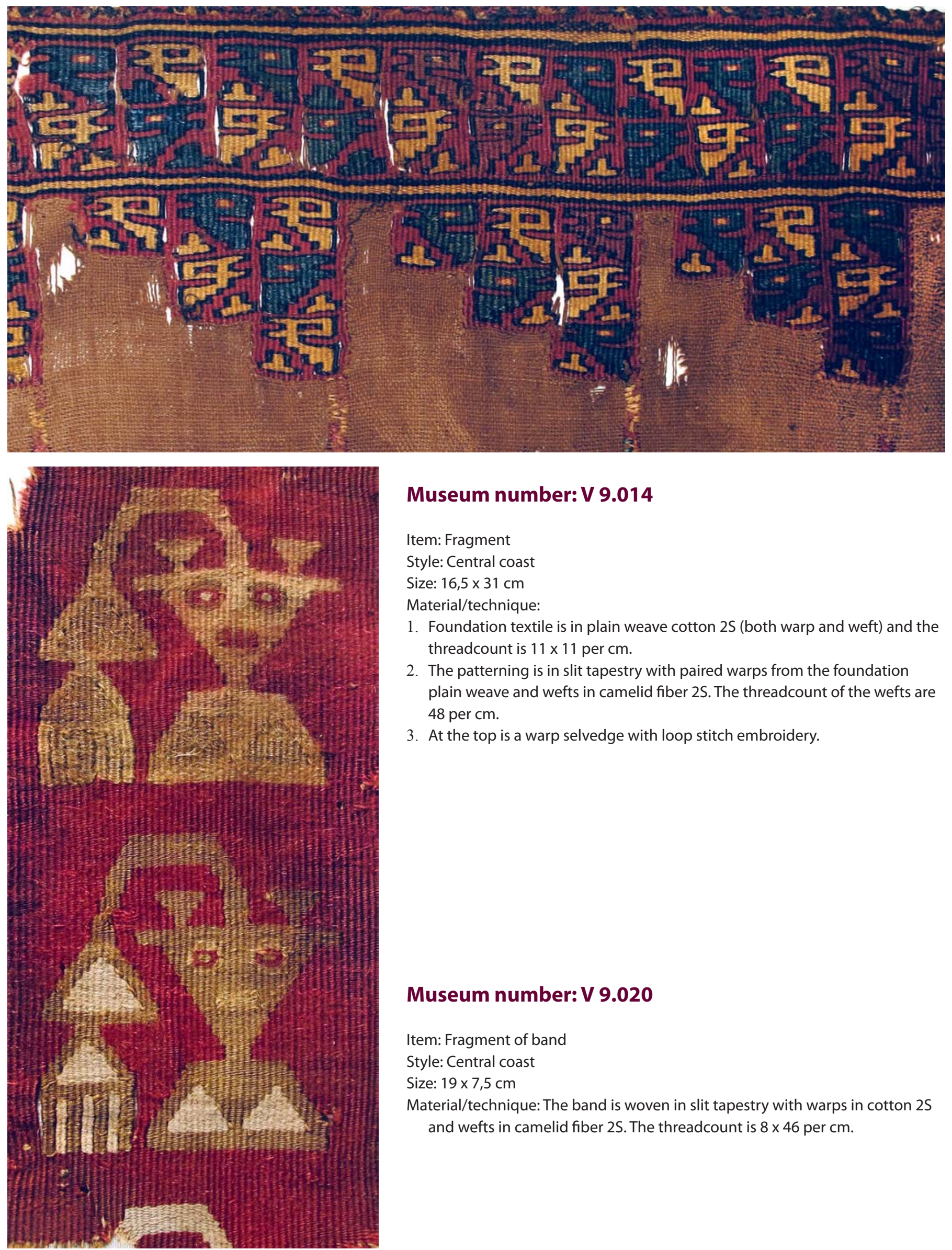

\section{Museum number: V 9.014}

Item: Fragment

Style: Central coast

Size: $16,5 \times 31 \mathrm{~cm}$

Material/technique:

1. Foundation textile is in plain weave cotton $2 S$ (both warp and weft) and the threadcount is $11 \times 11$ per $\mathrm{cm}$.

2. The patterning is in slit tapestry with paired warps from the foundation plain weave and wefts in camelid fiber $2 \mathrm{~S}$. The threadcount of the wefts are 48 per $\mathrm{cm}$.

3. At the top is a warp selvedge with loop stitch embroidery.

\section{Museum number: V 9.020}

Item: Fragment of band

Style: Central coast

Size: $19 \times 7,5 \mathrm{~cm}$

Material/technique: The band is woven in slit tapestry with warps in cotton $2 \mathrm{~S}$ and wefts in camelid fiber $2 \mathrm{~S}$. The threadcount is $8 \times 46$ per $\mathrm{cm}$. 


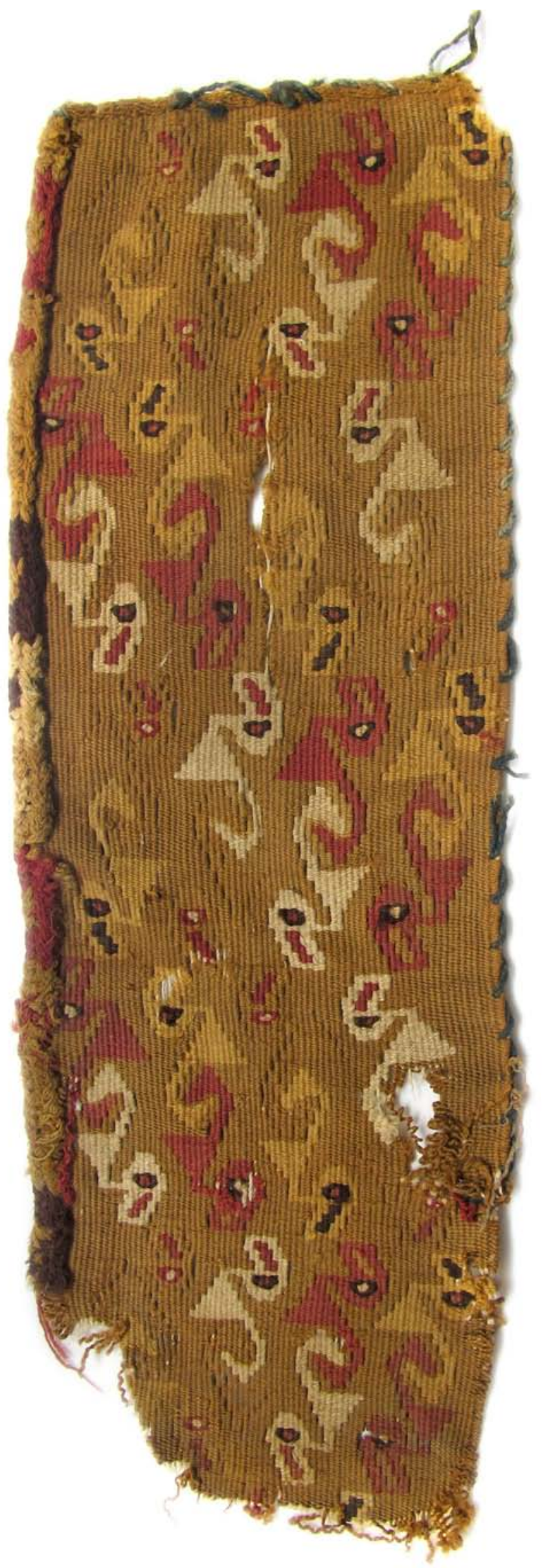

\section{Museum number: V 9.022}

Item: Fragment of a band

Style: Central coast

Size: $26 \times 9 \mathrm{~cm}$

Material/technique: Tapestry woven band with 3 selvedges in camelid fiber 2S. At one side selvedge the band has a loop stitch embroiderey. Along the other side selvedge and along the warp selvedge are fragments of a stitching with a blue yarn.

\section{Museum number: V 9.023}

Item: Fragment, probably of a bag

Style: Central Coast, Ychsma

Size: $22 \times 12 \mathrm{~cm}$

Material/technique: The textile is woven in tapestry and has cotton warp, $3 \mathrm{~S}$ and camelid fiber wefts, $2 \mathrm{~S}$. The threadcount is 9 $x 50$ per $\mathrm{cm}$.

The fragment has warp selvedge and one side selvedge. Attatched to the side selvedge is a loop stitch embroidery.

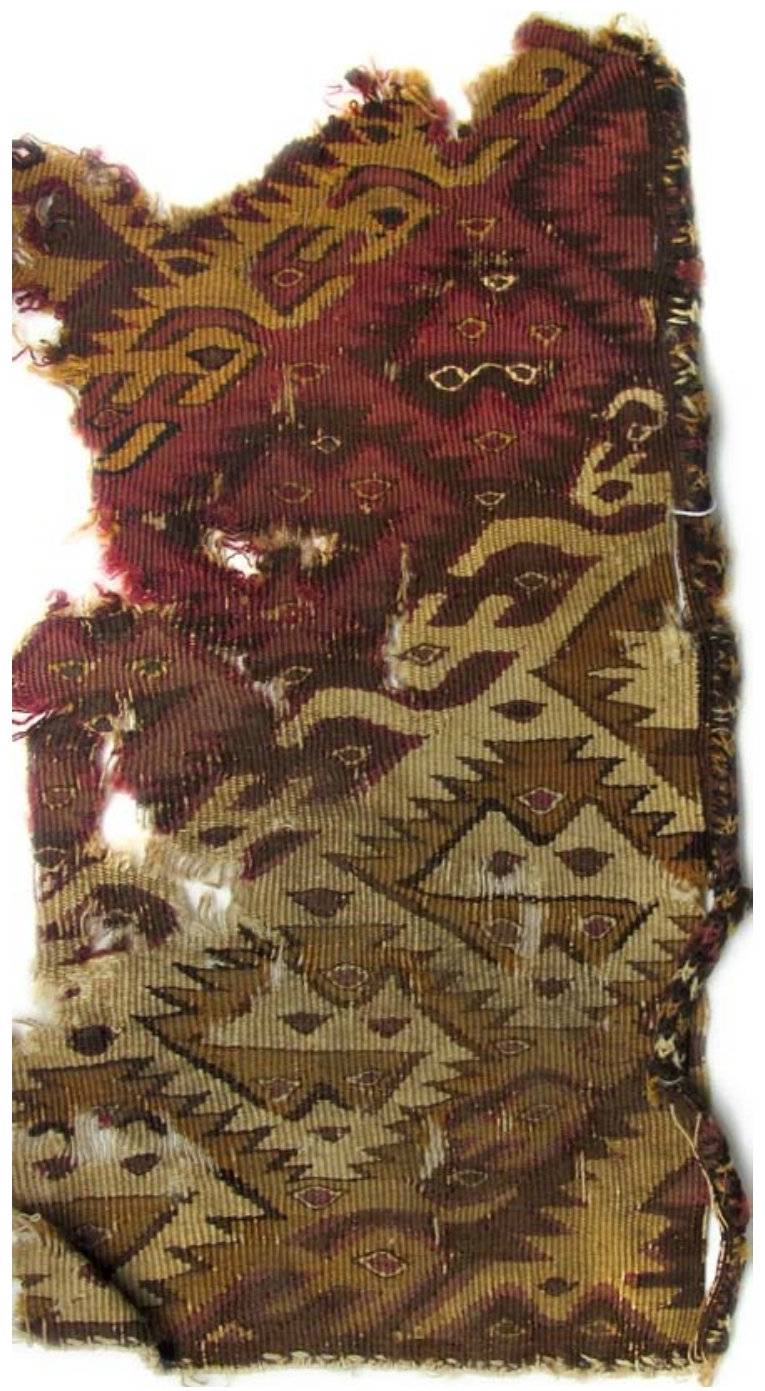




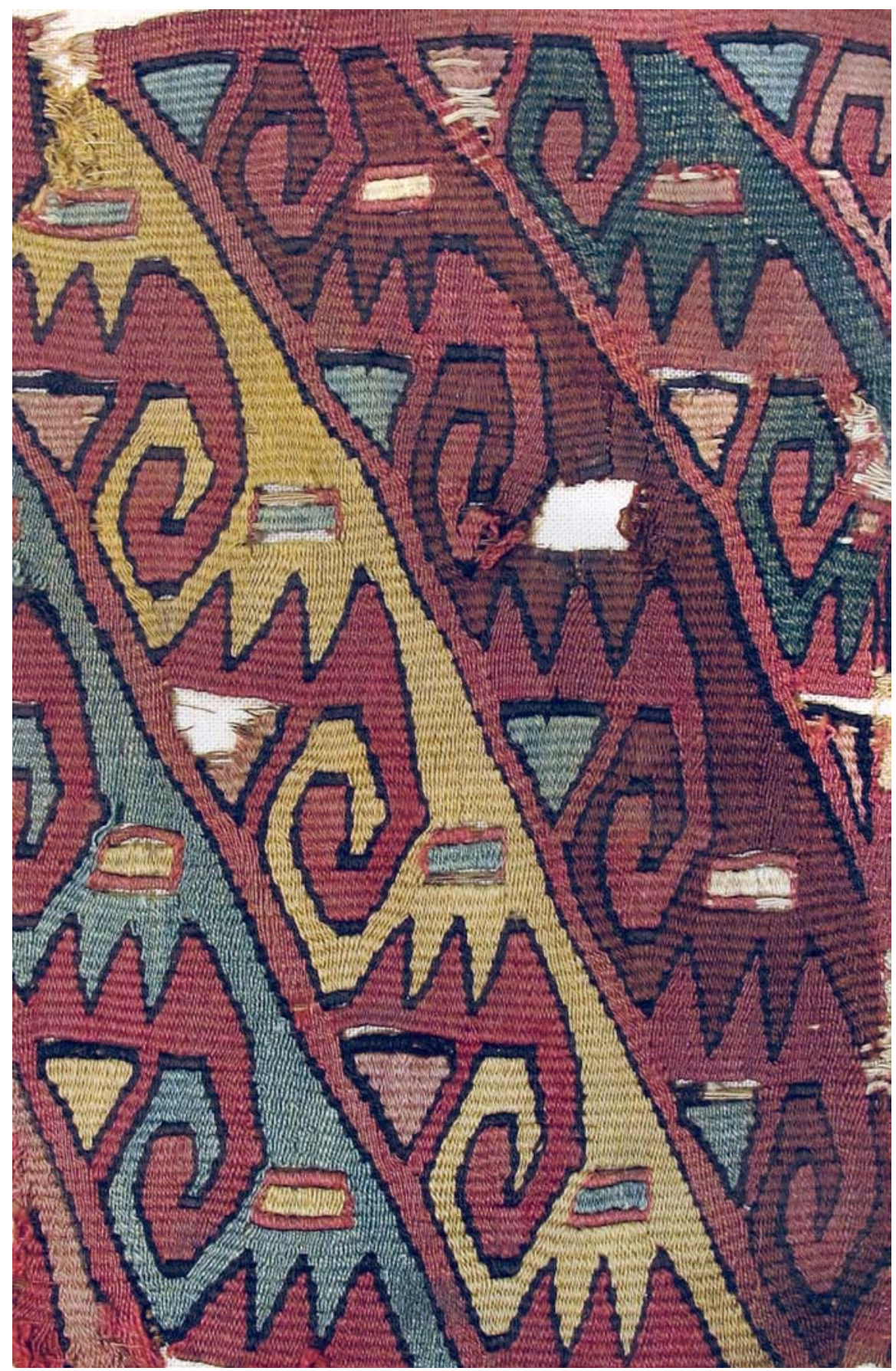

\section{Museum number: V 9.052}

Item: Fragment

Style: Central coast

Size: $15 \times 18 \mathrm{~cm}$

Material/technique: The textile is woven in plain weave and slit tapestry. The plain weave has cotton $2 S$ in both warp and weft. The threadcount is $38 \times 15$ per $\mathrm{cm}$.

In the tapestry the warp is 4 warps of the plain weave in each shed and the weft is camelid fiber 25 . The threadcount in the tapestry is $7 \times 40$ per $\mathrm{cm}$.

Further description: At bottom is a $2,5 \mathrm{~cm}$ wide woven fringe - partly tapestry, partly plain weave. 


\section{Museum number: V 9.081}

Item: Band

Style: Central coast

Size: $17 \times 17 \mathrm{~cm}$

Material/technique: The textile is woven in tapestry with the warp in cotton $2 S$ and the weft in camelid fiber $2 \mathrm{~S}$. The threadcount is $8 \times 26$ per $\mathrm{cm}$

The textile has two side-selvedges.
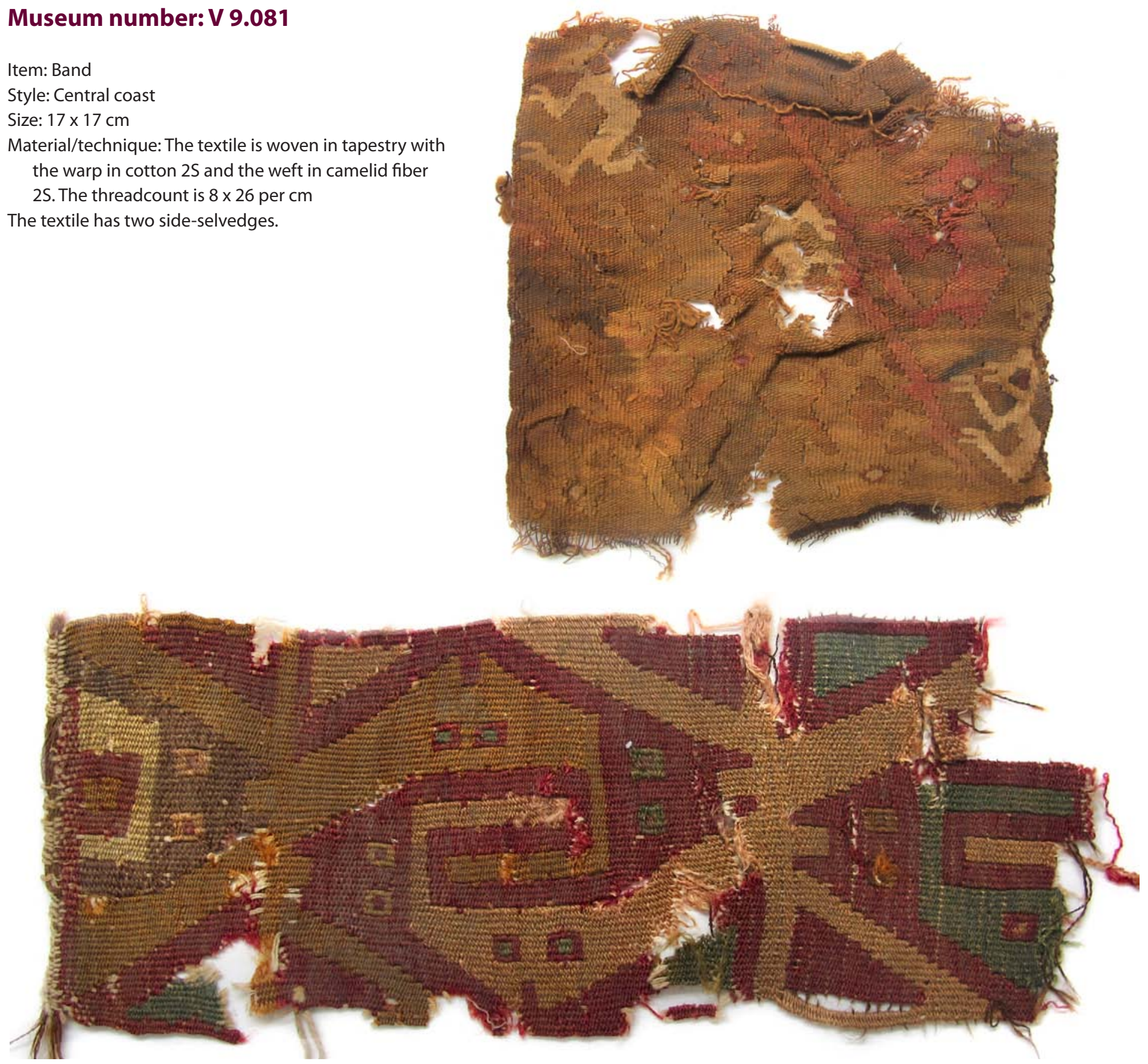

Museum number: V 9.083

Item: Fragment

Style: Central Coast

Size: $16 \times 6 \mathrm{~cm}$

Material/technique: The weaving is tapestry with the warp in paired camelid fiber $2 \mathrm{~S}$. The weft is also camelid fiber $2 \mathrm{~S}$. The threadcount is $10 \times 28$ per $\mathrm{cm}$.

One warp selvedge.

Further description: the part of the textile closest to the warp selvedge has its vertical lines interlinked as dovetailed tapestry. The lower part, however, has every 5 wefts an extra dark weft going from edge to edge, which is invisible but keeping the vertical tapestry lines together without being interlinked. 


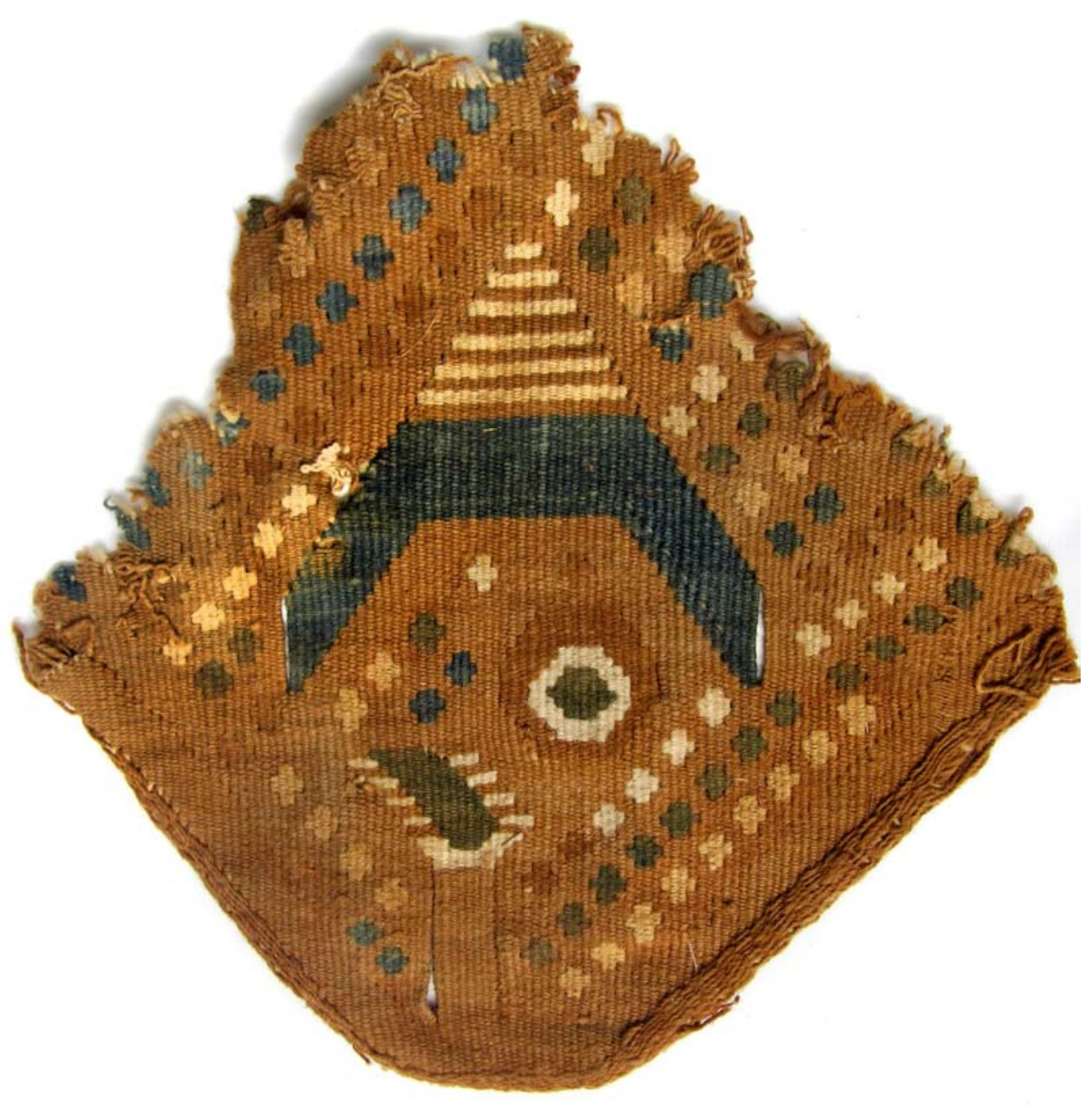

\section{Museum number: V 9.090}

Item: Fragment

Style: Central Coast, Ychsma

Size: $15 \times 15 \mathrm{~cm}$

Material/technique: The textile is in slit tapestry with all yarns in cotton $2 \mathrm{~S}$. The threadcount is $8 \times 46$ per $\mathrm{cm}$.

The fragment is probably a patch from a shroud. It is cut as a diamond with the warp diagonal and edged with $0,5 \mathrm{~cm}$ wide running stitch embroidery.

\section{Museum number: V 9.101}

Item: Fragment

Style: Central Coast

Size: $57 \times 4,5 \mathrm{~cm}$

Material/technique: The textile yarns are all cotton $2 \mathrm{~S}$ and the technique is plain weave and complementary warp weave. The threadcount is 20 x 13 per $\mathrm{cm}$.

There is one warp selvedge and one weft selvedge.

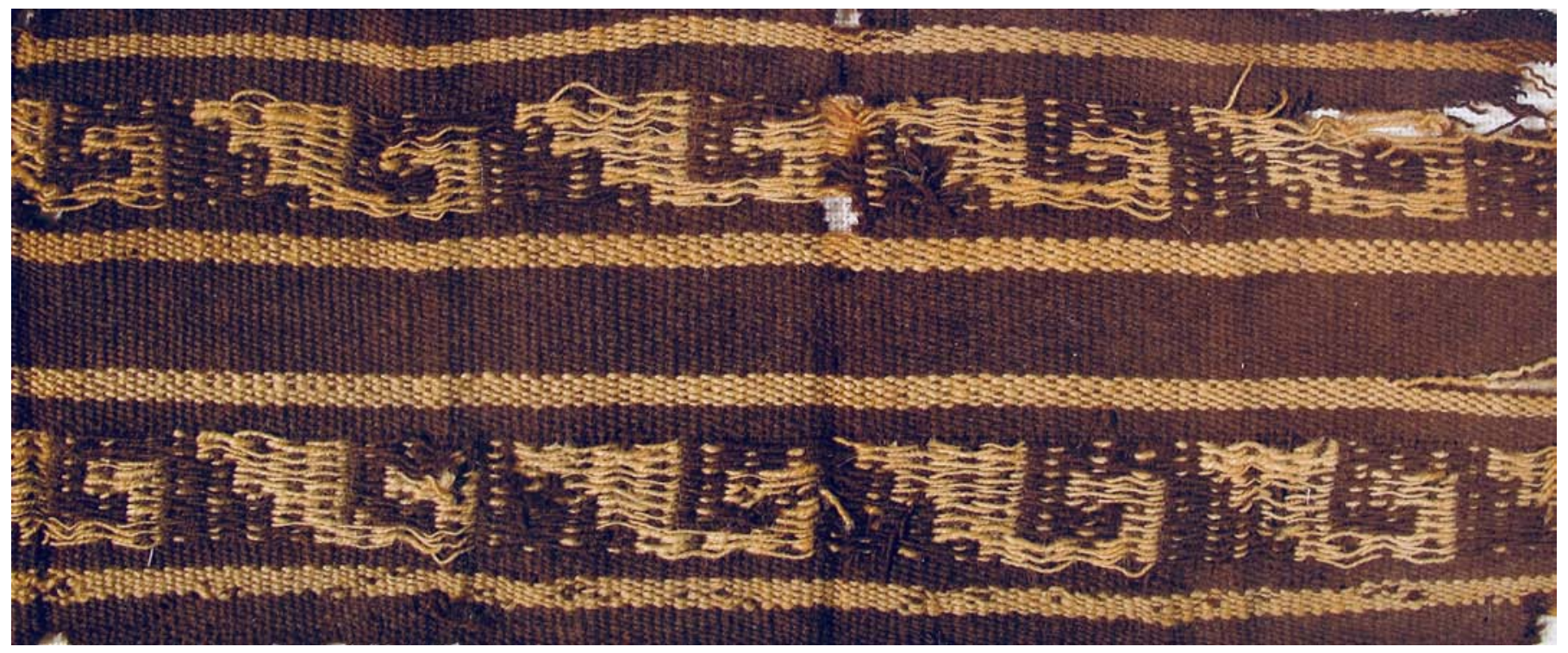




\section{Museum number: V 9.139, and V 9.310}

Item: Fragments of mantle

Style: Central Coast

Size: V9.139: $95 \times 55 \mathrm{~cm}$, V9.318: $192 \times 160 \mathrm{~cm}$,

V9.310: $22 \times 33 \mathrm{~cm}$

Material/technique: The mantle consists of 5 panels woven in plain weave with both warp and weft in camelid $2 \mathrm{~S}$. The threadcount is $11 \times 11$ per $\mathrm{cm}$. Between the monocrome panels separately woven are $4,5 \mathrm{~cm}$ wide tapestry bands with abstract antropomorphic motives. These bands are stitched between the plain weave panels. At either end of the mantle is $10 \mathrm{~cm}$ tapestry (with the same patterns as the inserted bands) with $4 \times 1 \mathrm{~cm}$ woven fringes.
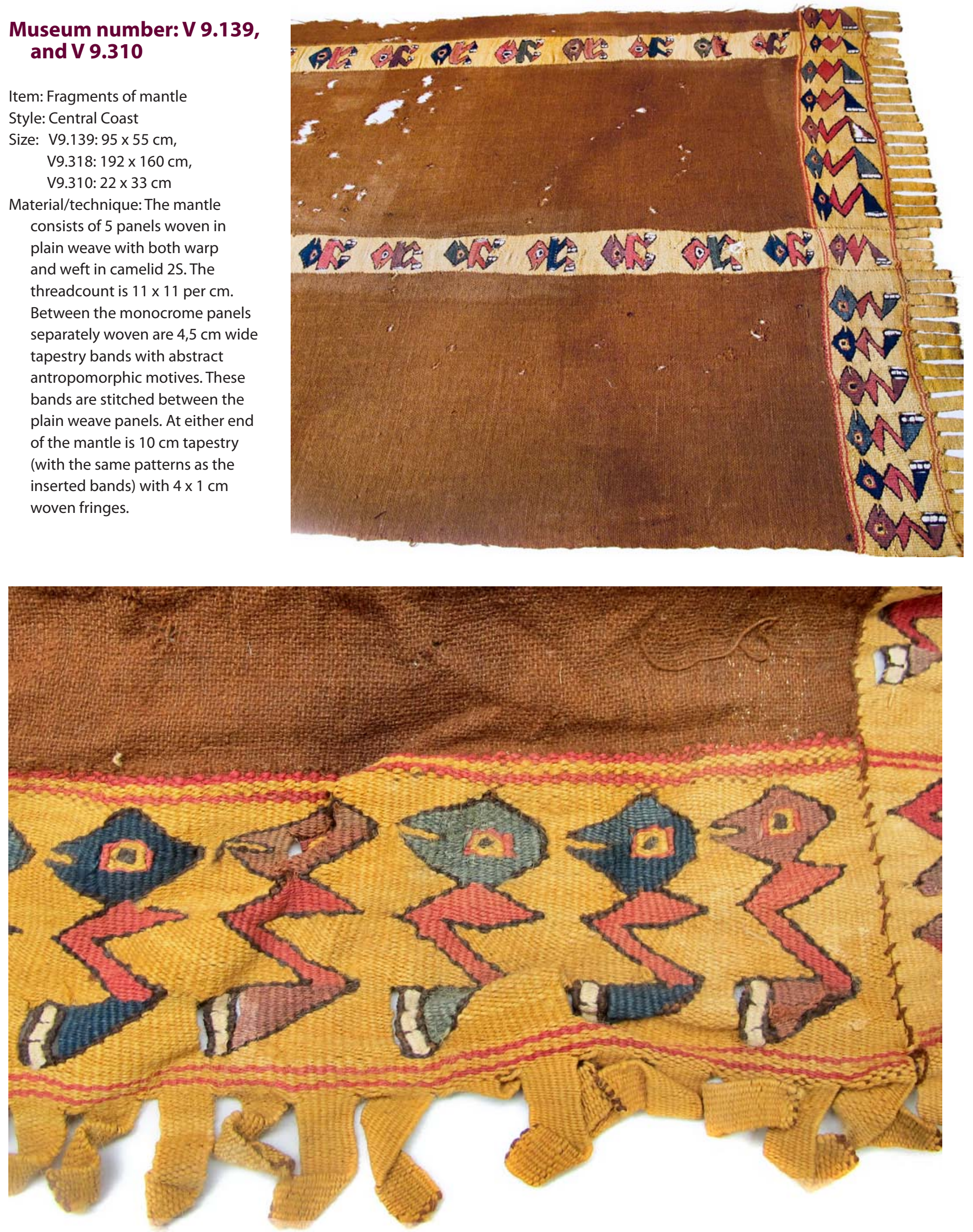

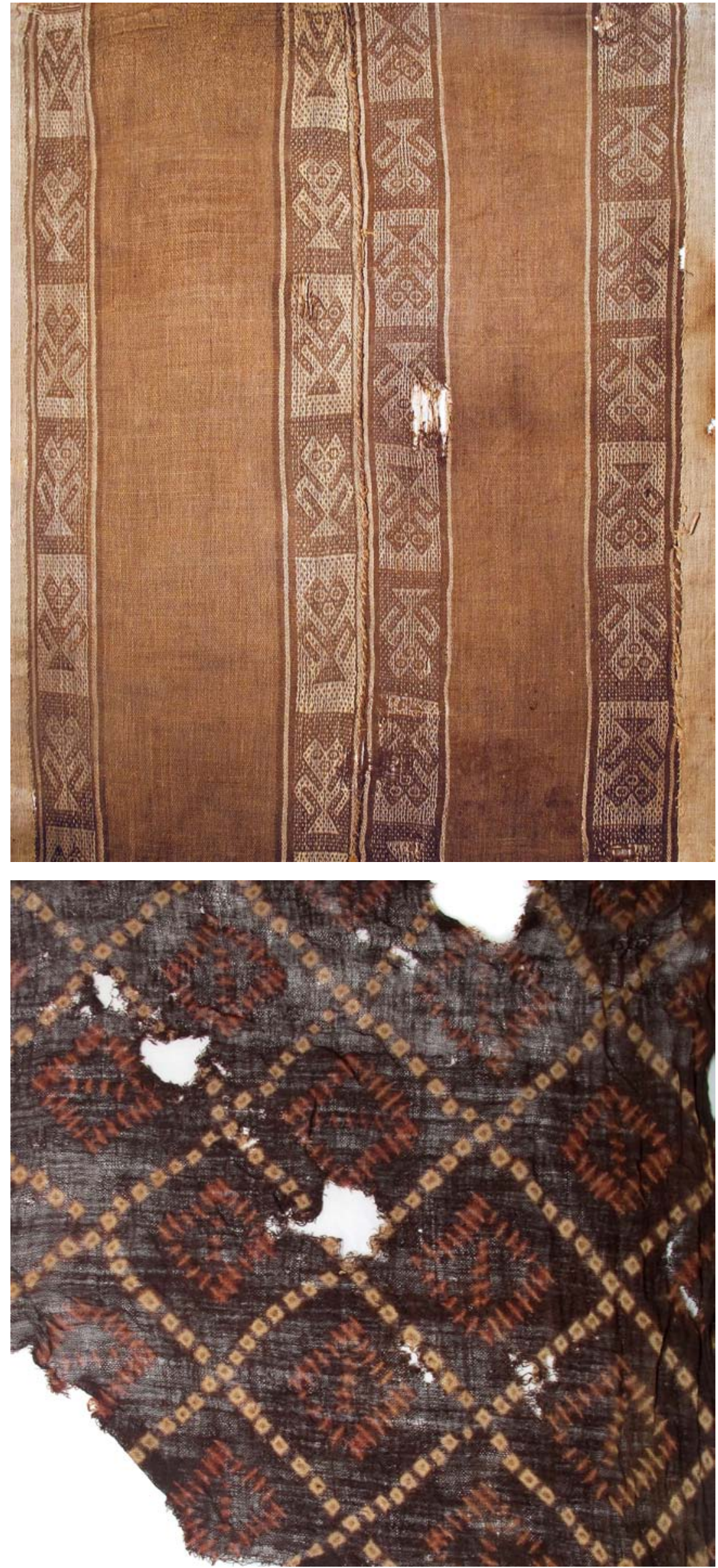

\section{Museum number: V 9.142}

Item: Fragment

Style: Central Coast

Size: $65 \times 47 \mathrm{~cm}$

Material/technique:

1. A cotton ( $2 S$ warp - Z weft) textile of $41 \mathrm{~cm}$ width with complimentary warp patterning in stripes. This textile has one warp selvedge and two weft selvedges. The threadcount in the plain weave is $14 \times 8$ per $\mathrm{cm}$.

2. On both sides the textile is sewn to $3 \mathrm{~cm}$ wide fragments of plain weave cotton textiles which has one warp selvedge at bottom and one side selvedge towards the seam and is cut at the other side. This warp is $2 \mathrm{~S}$ and the weft $Z$. The threadcount is $10 \times 10$ per $\mathrm{cm}$.

\section{Museum number: V 9.158}

Item: Fragment of scarf/shawl

Style: Central coast

Size: $78 \times 50$

Material/technique: Plain weave in cotton $\mathrm{Z}$. Threadcount $12 \times 10$ per $\mathrm{cm}$.

The textile was originally of at least 2 panels (48 $\mathrm{cm}$ wide) - a small fragment $(2 \times 3 \mathrm{~cm})$ of the second panel is still in place.

The large panel has warp selvedge, and fragments of two side-selvedges.

The patterning technique is tie dye. With 4 colors - dyed 3 times (dark brown, reddish, light braun). 


\section{Museum number: V 9.172}

Item: mini (or child's?) tunic.

Style: Central Coast, Ychsma

Size: $33 \times 40$

Material/technique: The complete tunic has cotton $S$ warp. One panel with cut vertical $19 \mathrm{~cm}$ long neck hole! The cut edge is rolled and sewn down. The threadcount is in the warp 16 per $\mathrm{cm}$, in the gauze weave the weft varies. At the bottom of the warp is a $6,5 \mathrm{~cm}$ wide pattern with camelid fiber weft - in the center ( $2 \mathrm{~cm}$ wide) with a pattern in complementaryweft weave with discontinous-weft substitution. At either side of this is $2 \mathrm{~cm}$ wide weft face plain weave with 2 warps in each shed. This weft is camelid fiber $2 S$.

The rest of the tunic is gauze weave. One side a simple gauze all over - on the other side a more complicated and varied gauze.

At bottom is a $3 \mathrm{~cm}$ wide weft fringe band $-1,5 \mathrm{~cm}$ woven, $1,5 \mathrm{~cm}$ looped fringe (typical Ychsma). The warp of this band is $S$ cotton and the weft is camelid fiber $2 S$.

\section{Museum number: V 9.179}

Item: Complete textile with 4 selvedges.

Style: Central coast

Size: 4 x $40 \mathrm{~cm}$

Material/technique: The textile is plain weave in cotton, $2 \mathrm{~S}$, with warp supplementary patterning. The threadcount is $14 \times 12$ per $\mathrm{cm}$.
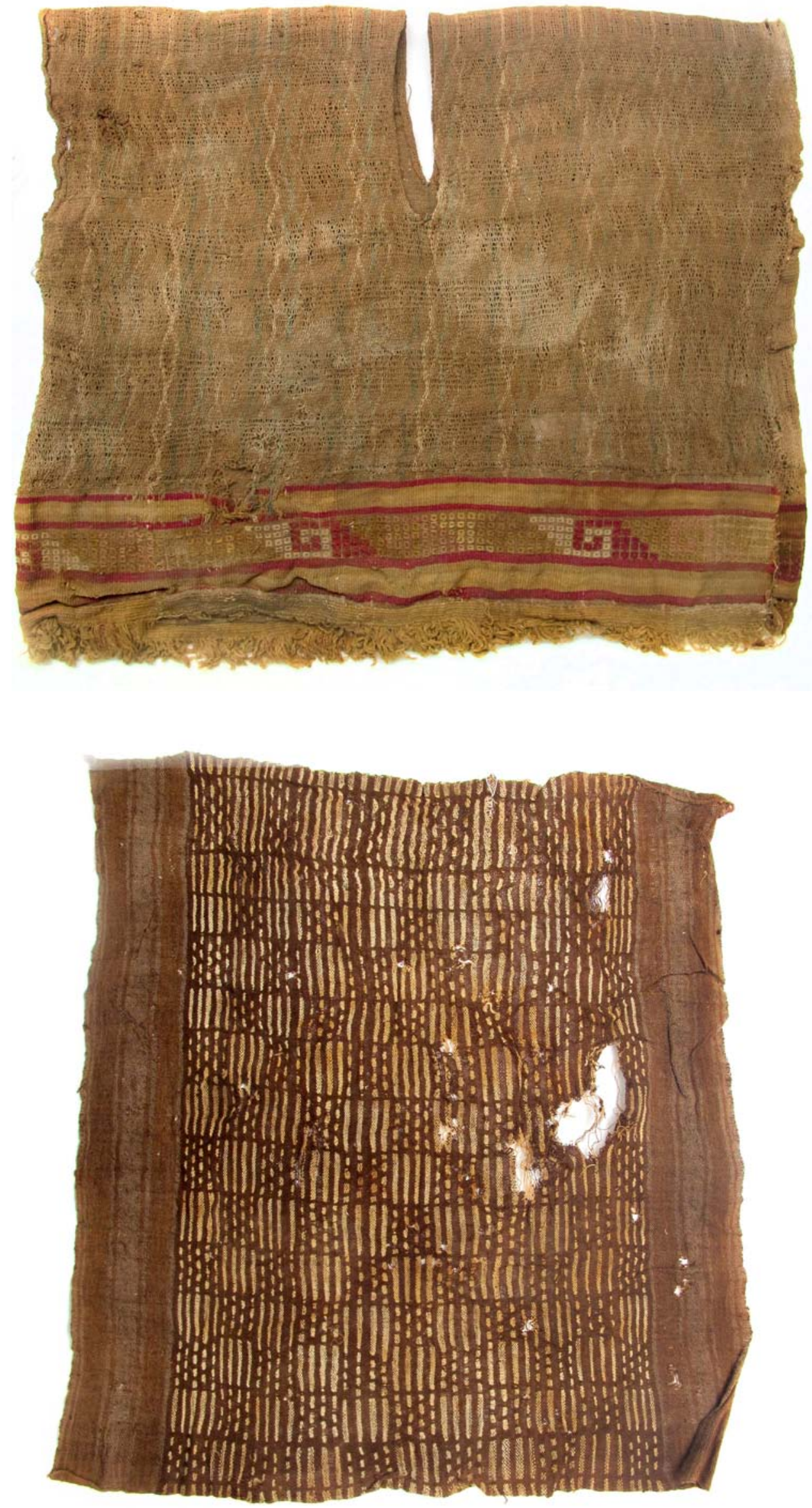


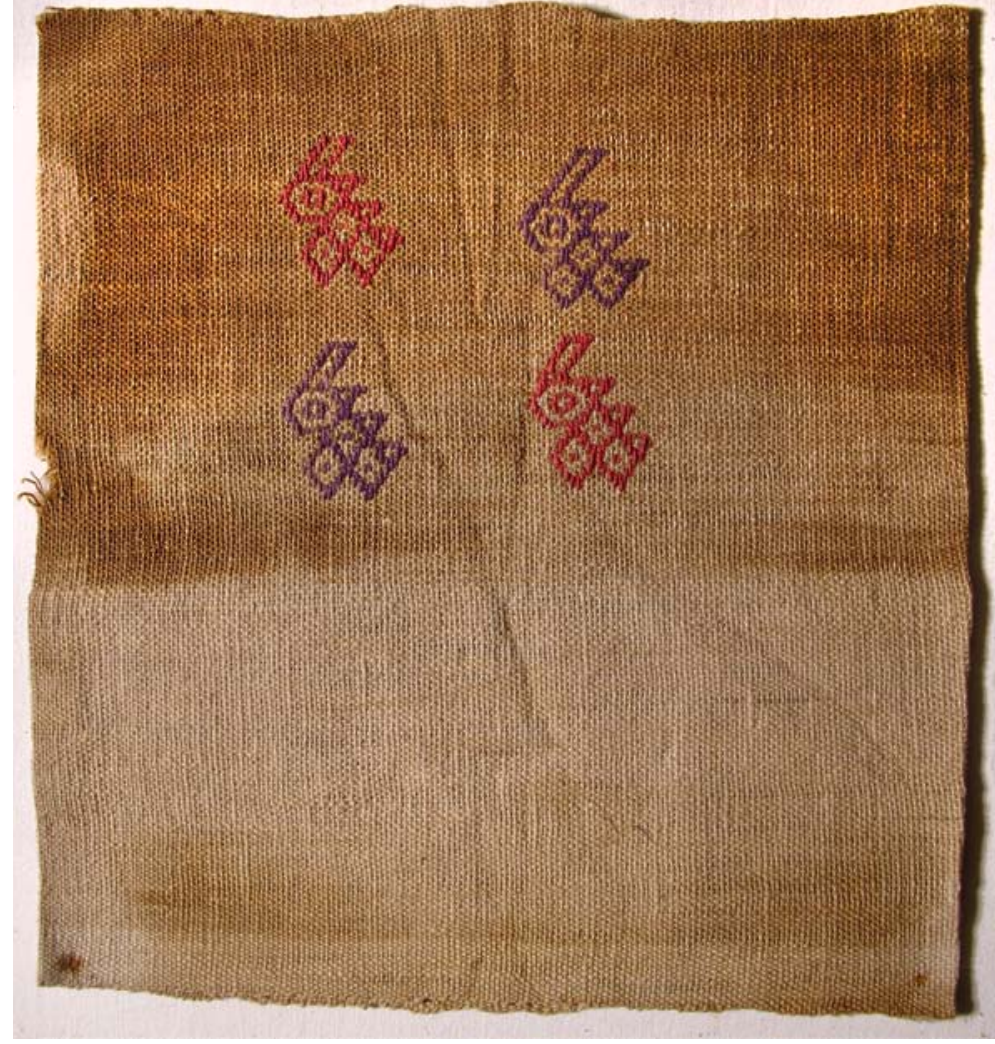

\section{Museum number: V 9.189}

Item: Complete mini woman's dress

Style: Central coast

Size: $28 \times 29 \mathrm{~cm}$

Material/technique: Plain weave cotton $2 \mathrm{~S}$ in both warp and weft. Warp horizontal when "worn". The threadcount is $10 \times 6$ per $\mathrm{cm}$.

4 brocaded birds in $2 \mathrm{~S}$ camelid fiber.

Further description: The complete warp is $56 \mathrm{~cm}$ (four selvedges), folded sideways (warp horizontal) and sewn together as a tube.

\section{Museum number: V 9.204}

Item: Fragment

Style: Central coast

Size: 33 x 13,5 cm

Material/technique: The textile is woven in double weave, cotton $2 \mathrm{~S}$ (both warp and weft). The threadcount is $14 \times 11$ per $\mathrm{cm}$. There is one side selvedge.

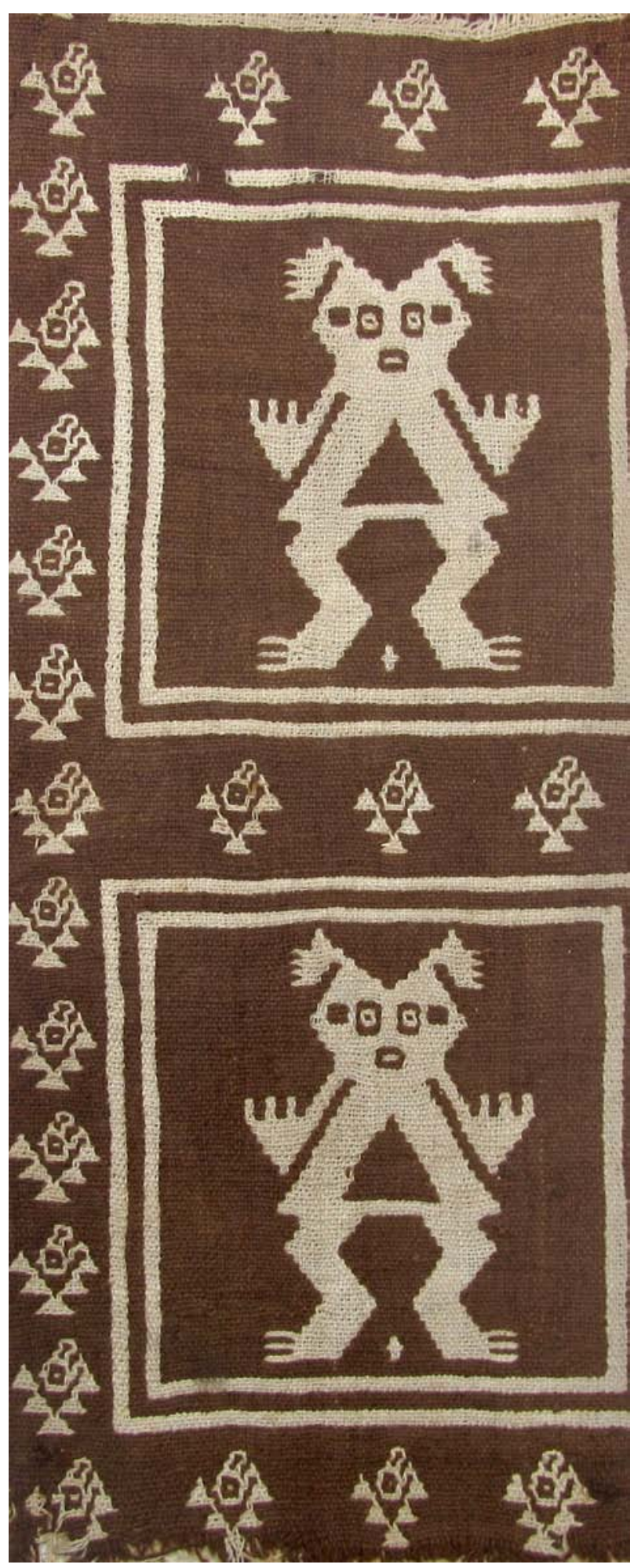




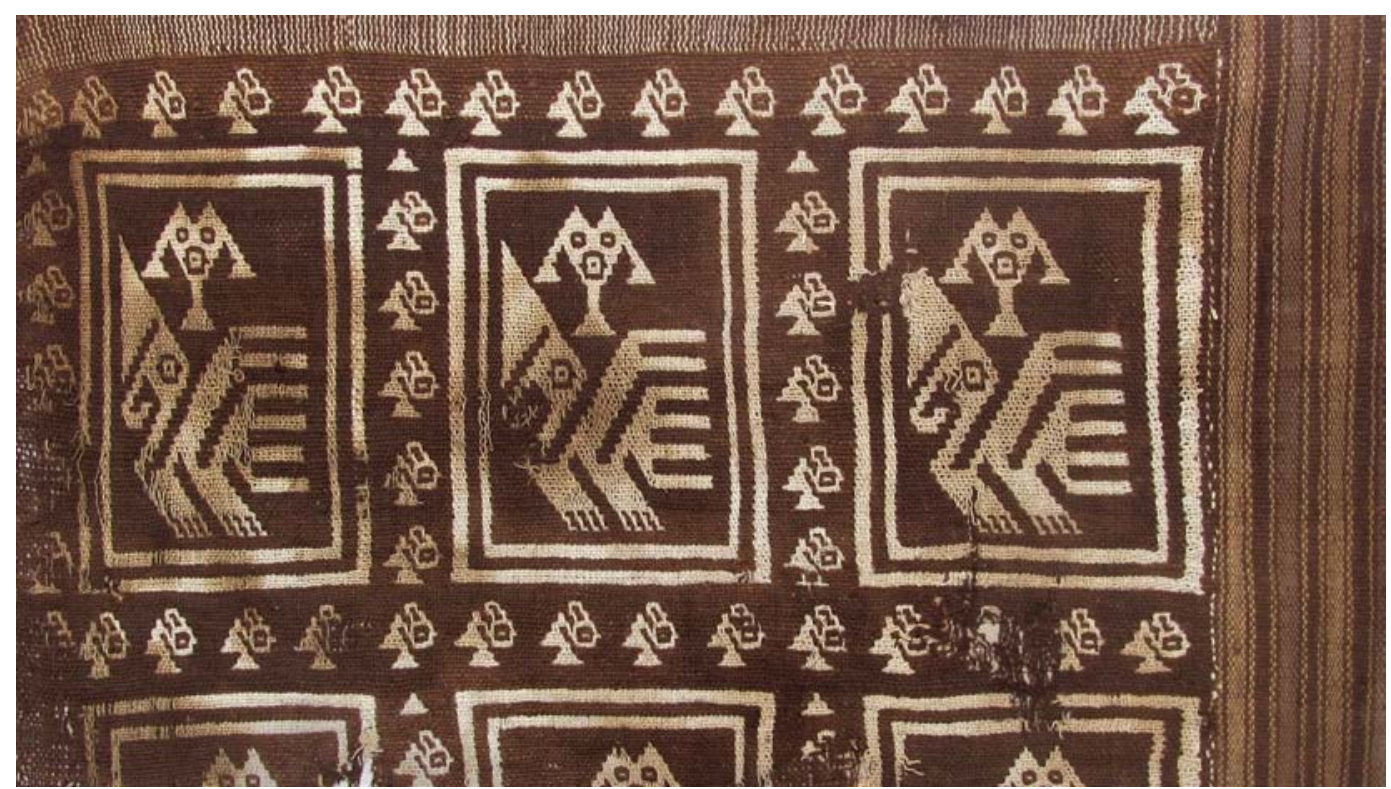

\section{Museum number: V 9.205}

Item: Fragment

Style: Central coast

Size: $19 \times 30 \mathrm{~cm}$

Material/technique: A double weave textile in cotton $2 \mathrm{~S}$ for both warp and weft. The threadcount is $16 \times 10$ per $\mathrm{cm}$, and the textile has two side selvedges.

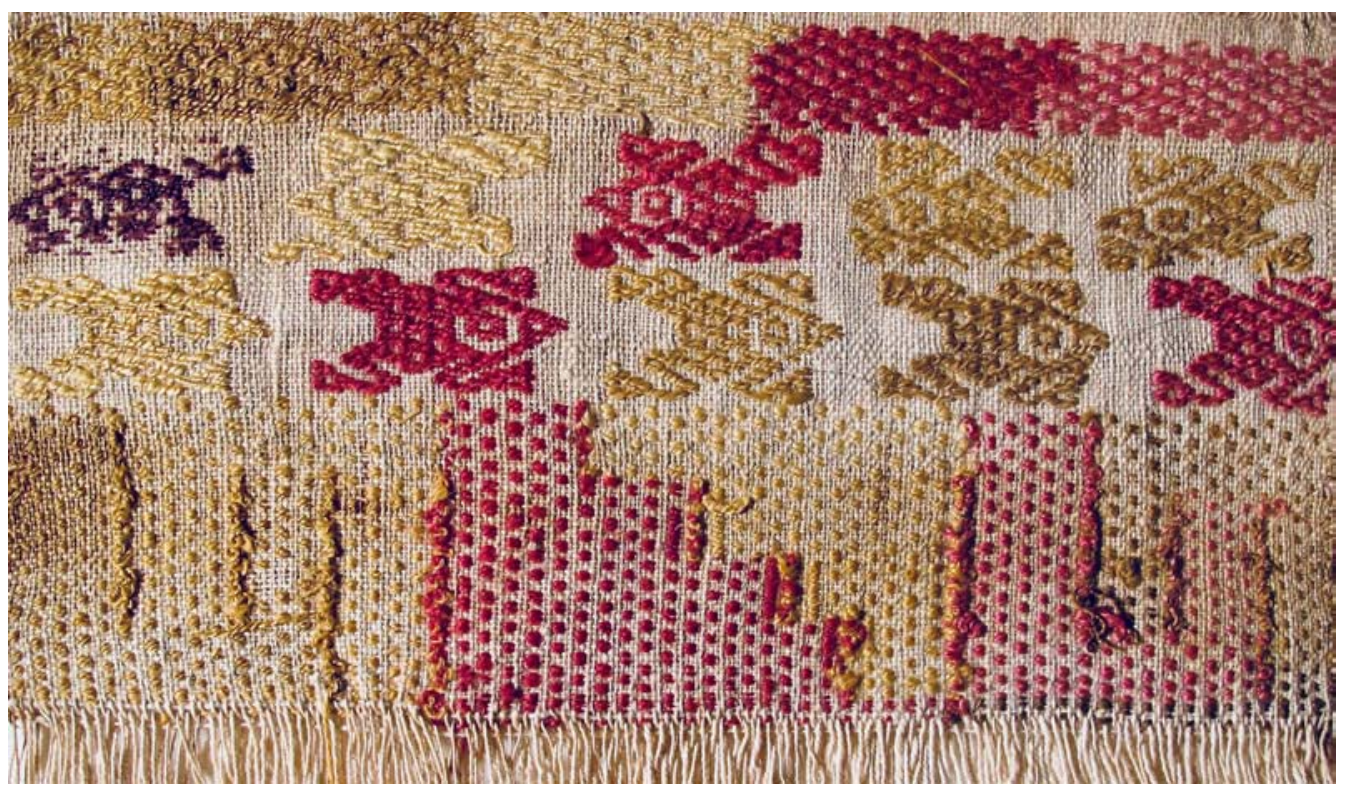

\section{Museum number: V 9.216}

Item: Fragment

Style: Central coast

Size: $14 \times 21 \mathrm{~cm}$

Material/technique: The technique is brocade on plain weave.

The plain weave has cotton $2 \mathrm{~S}$ for both warp and weft. The brocade pattern wefts are camelid fiber $2 \mathrm{~S}$. 


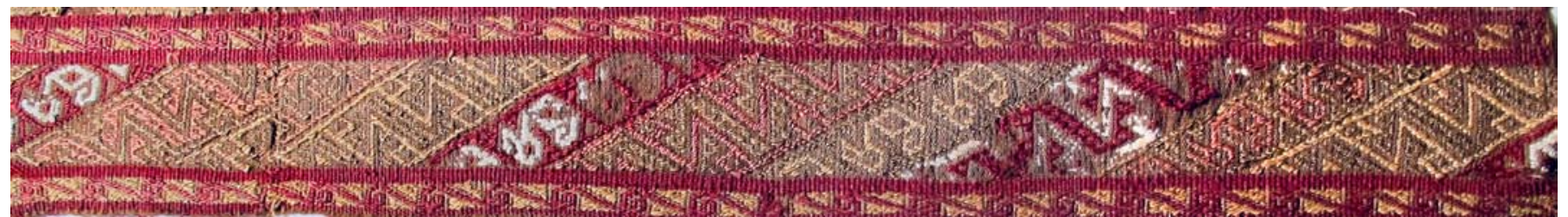

\section{Museum number: V 9.224}

Item: Fragment

Style: Central Coast, Ychsma

Size: $7 \times 47 \mathrm{~cm}$

Material/technique: The textile is the bottom edge of a cotton tunic - warp and weft are 2S. The pattern is in supplementary weft (lancée) in camelid fiber $2 \mathrm{~S}$. The warp selvedge is intact. At the warp selvedge a fragment of a $1 \mathrm{~cm}$ wide looped weft fringe is stitched on - 0,5 $\mathrm{cm}$ weaving (4 warps) and has $0,5 \mathrm{~cm}$ looped loose wefts.
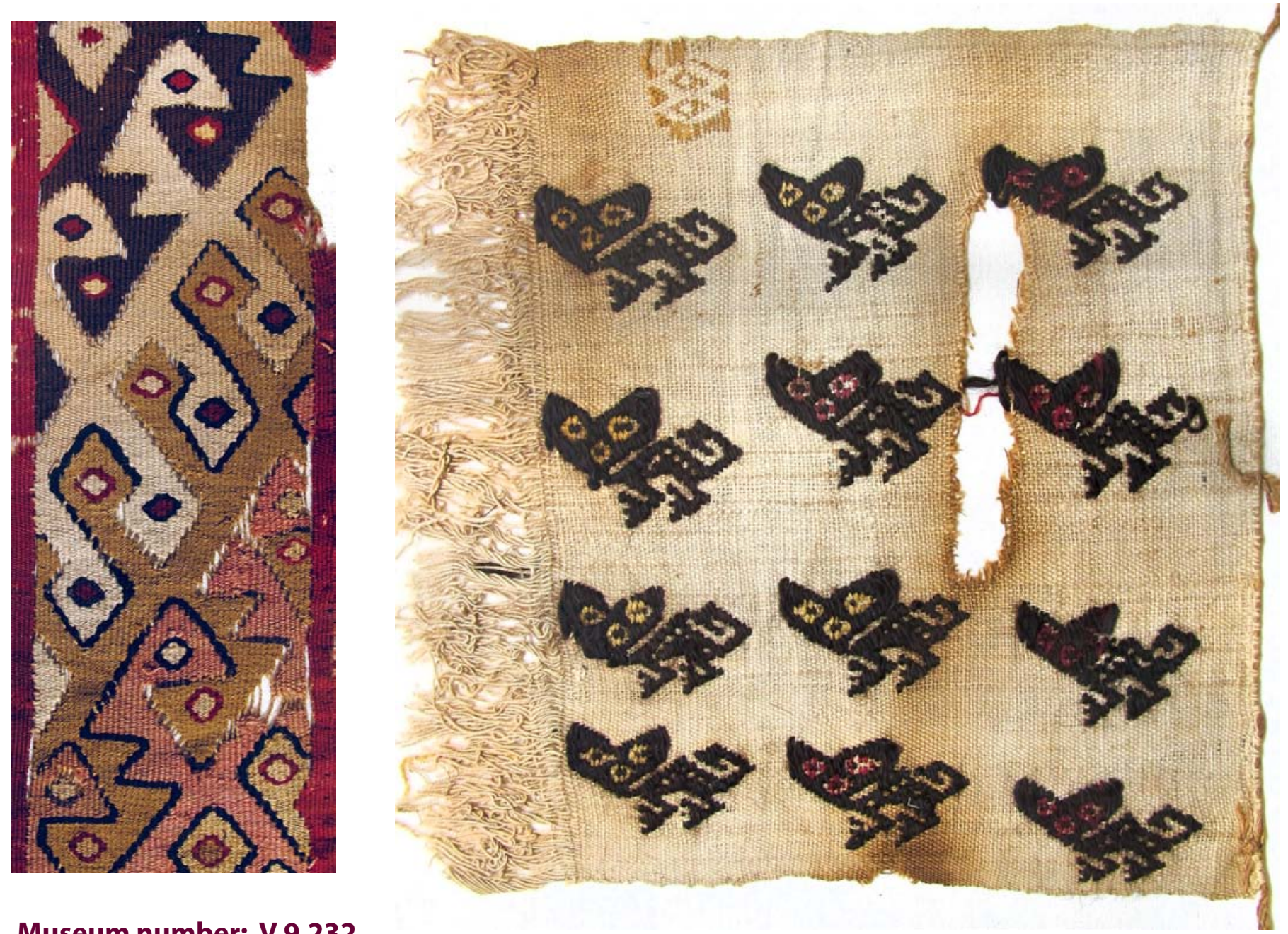

\section{Museum number: V 9.232}

\section{Museum number: V $\mathbf{9 . 2 3 4}$}

Item: Fragment of a band

Style: Central coast

Size: $6 \times 26 \mathrm{~cm}$

Material/technique: The band has two side selvedges and no warp selvedge.

It is tapestry weaving. The warp is cotton $2 \mathrm{~S}$. The weft is camelid fiber $2 \mathrm{~S}$ and cotton $\mathrm{S}$. The threadcount is $8 \times 34$ per $\mathrm{cm}$.

Item: Fragment

Style: Central coast

Size: $19 \times 20 \mathrm{~cm}$

Material/ technique: Cotton textile with 3 selvedges woven in plain weave. Both warp and weft are $2 \mathrm{~S}$. The threadcount $16 \times 10$ per $\mathrm{cm}$.

The patterns are brocaded animals (cats) in $2 \mathrm{~S}$ camelid fiber. At one end there is $4 \mathrm{~cm}$ warp fringe. 


\section{Museum number: V 9.235}

Item: Fragment

Style: Central Coast, Ychsma

Size: $38 \times 35 \mathrm{~cm}$

Material/technique: The upper part of the fragment $(15 \mathrm{~cm})$ is in slit tapestry. The warp is cotton $2 \mathrm{~S}$, the weft is camelid fiber $2 \mathrm{~S}$. The threadcount is $6 \times 36$ per $\mathrm{cm}$. The textile has warp selvedge at the left side and weft selvedge at top and bottom.

At bottom is a $19 \mathrm{~cm}$ weft fringe $(1,5$ $\mathrm{cm}$ woven (7 warps), $17 \mathrm{~cm}$ looped wefts) with warps in 25 cotton and wefts in $2 \mathrm{~S}$ camelid fiber.
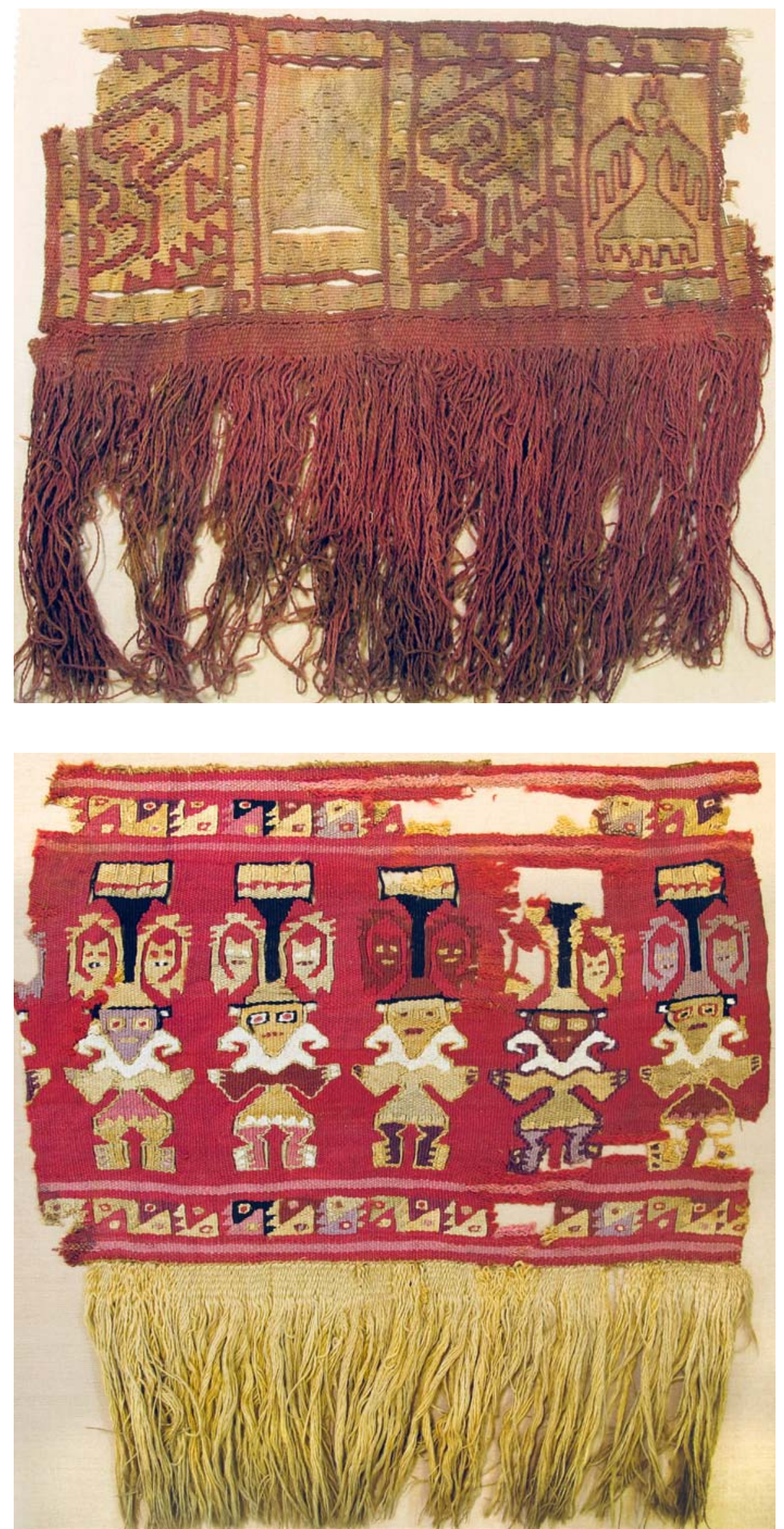

Item: Fragment

Style: Central Coast, Chancay

Size: $25 \times 27 \mathrm{~cm}$

Material/technique: The fragment consists of a $17 \mathrm{~cm}$ wide slit tapestry with warp in cotton $2 \mathrm{~S}$ and weft in camelid fiber $2 \mathrm{~S}$. The threadcount is $11 \times 30$ per $\mathrm{cm}$. The fragment has two warp selvedges and one weft selvedge (right in photo).

At bottom is a $10 \mathrm{~cm}$ weft fringe in camelid fiber $2 \mathrm{~S}(1 \mathrm{~cm}$ woven $(5$ warps, cotton S) $-9 \mathrm{~cm}$ loose wefts (cut at bottom).

it
1,5
top
and

\section{Museum number: V 9.241}




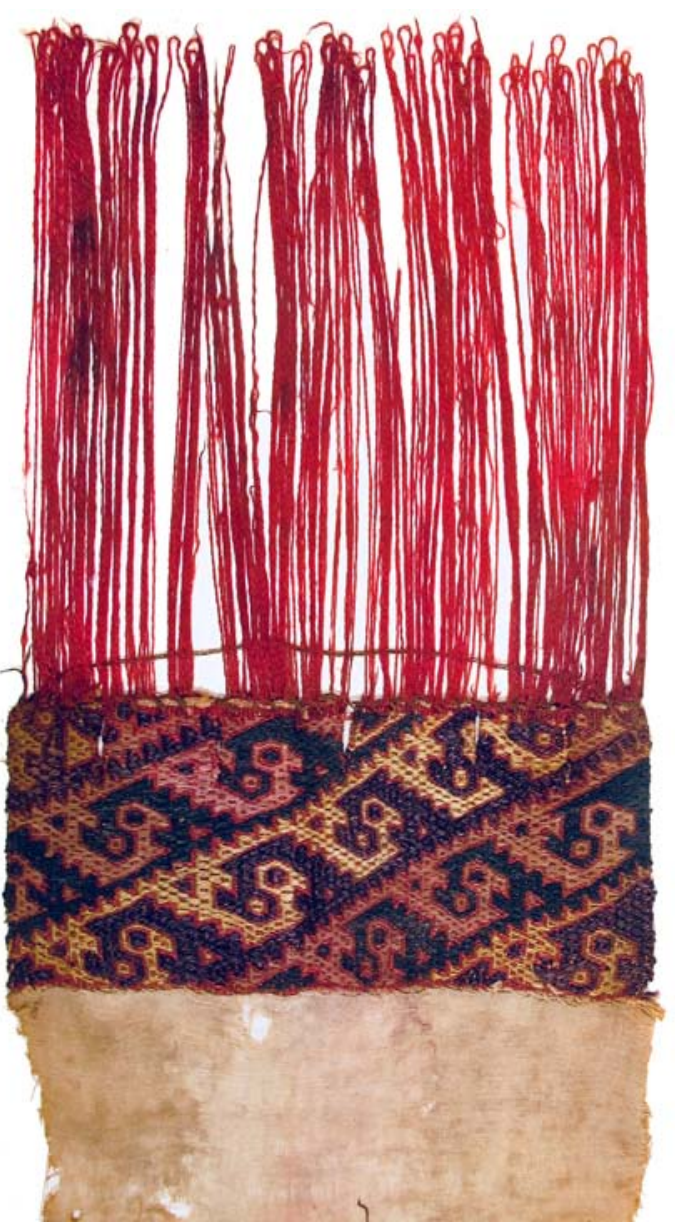

\section{Museum number: V 9.260}

Item: One side of a bag?

Style: Central Coast, Ychsma

Size: $42 \times 21 \mathrm{~cm}$

Material/technique:

1. Top: $10 \times 20 \mathrm{~cm}$ plain weave in cotton $\mathrm{S}$ with a threadcount of $15 \times 15$ per $\mathrm{cm}$. On all sides are complete or fragments of selvedges.

2. Center part: Complimentary weft weave with wefts in camelid fiber $2 \mathrm{~S}$ and warps in cotton $2 \mathrm{~S}$.

3. Looped fringe $-23 \mathrm{~cm}$, in camelid fiber $2 \mathrm{~S}$.

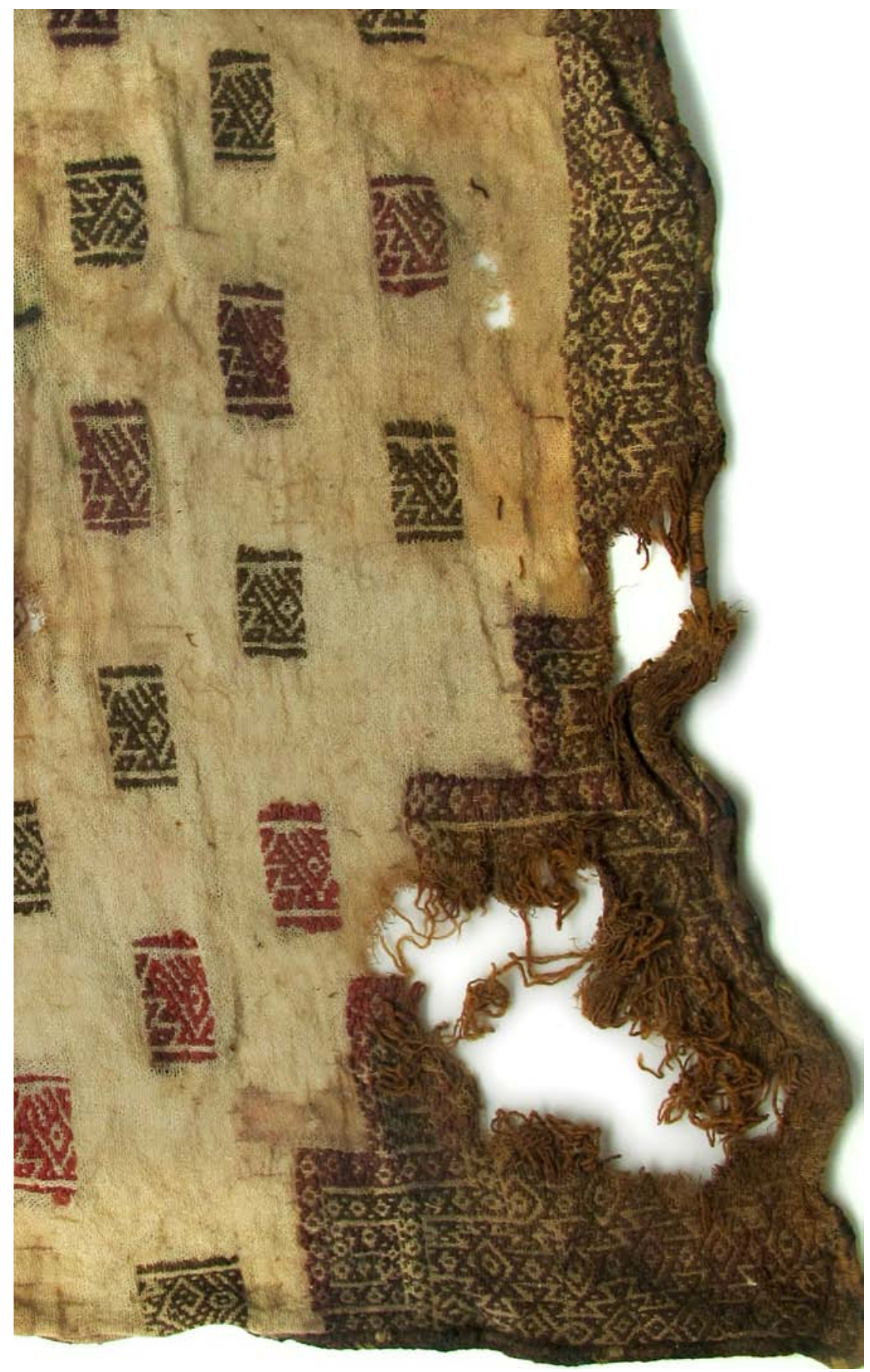

\section{Museum number: V 9.264}

Item: Fragment of a mantle

Style: Central coast (south coast?)

Size: $26 \times 30 \mathrm{~cm}$

Material/technique: Corner of a mantle.

The textile is in plain weave cotton S (both warp and weft). The threadcount is $20 \times 15$ per $\mathrm{cm}$.

The designs are in negative brocade in camelid fiber $2 \mathrm{~S}$. The textile is edged with cross loop embroidery also in camelid fiber $2 \mathrm{~S}$. 


\section{Museum number: V 9.271}

Item: Fragment of band

Style: Central coast

Size: 49 × $5 \mathrm{~cm}$

Material/technique: The band has one warp selvedge and two weft selvedges. The warp is lengthwise.

The techniques are complementary warp weave and warp rep.

Both warp and weft are cotton $2 \mathrm{~S}$. The threadcount is $34 \times 10$ per $\mathrm{cm}$.

\section{Museum number: V 9.277}

Item: Fragment

Style: Central Coast, Ychsma

Size: 14 × $38 \mathrm{~cm}$

Material/technique:

1. $11 \mathrm{~cm}$ plain weave with brocaded designs. The pattern wefts are in $2 \mathrm{~S}$ camelid fiber. The foundation textile is in plain weave cotton - the warp is $2 S$ and the weft $S$. The threadcount is $15 \times 16$ per $\mathrm{cm}$. There is a warp selvedge at the bottom, where the fringe-band is attatched.

2. $2 \mathrm{~cm}$ wide weft fringe-band $-1 \mathrm{~cm}$ is woven, $1 \mathrm{~cm}$ is looped wefts.
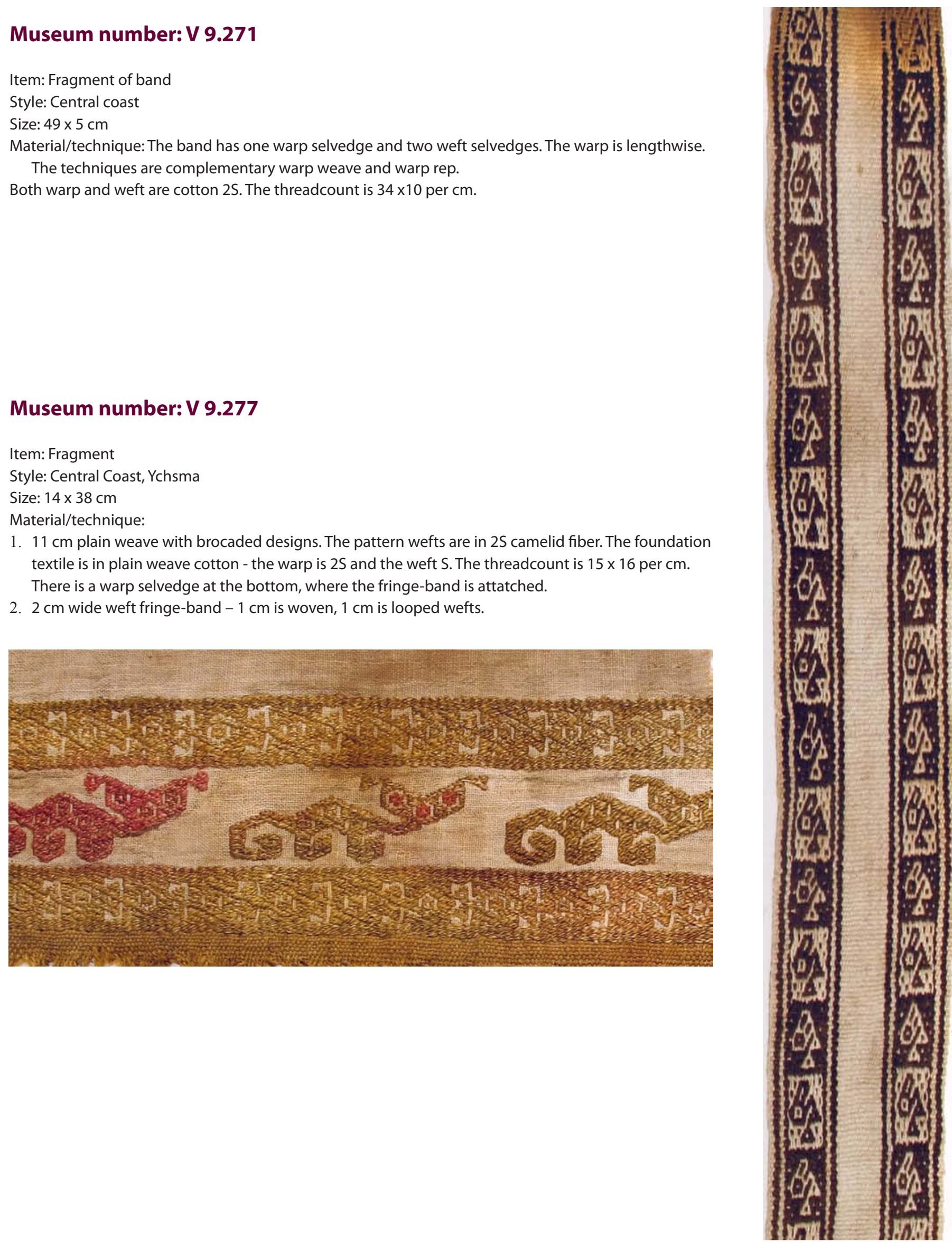


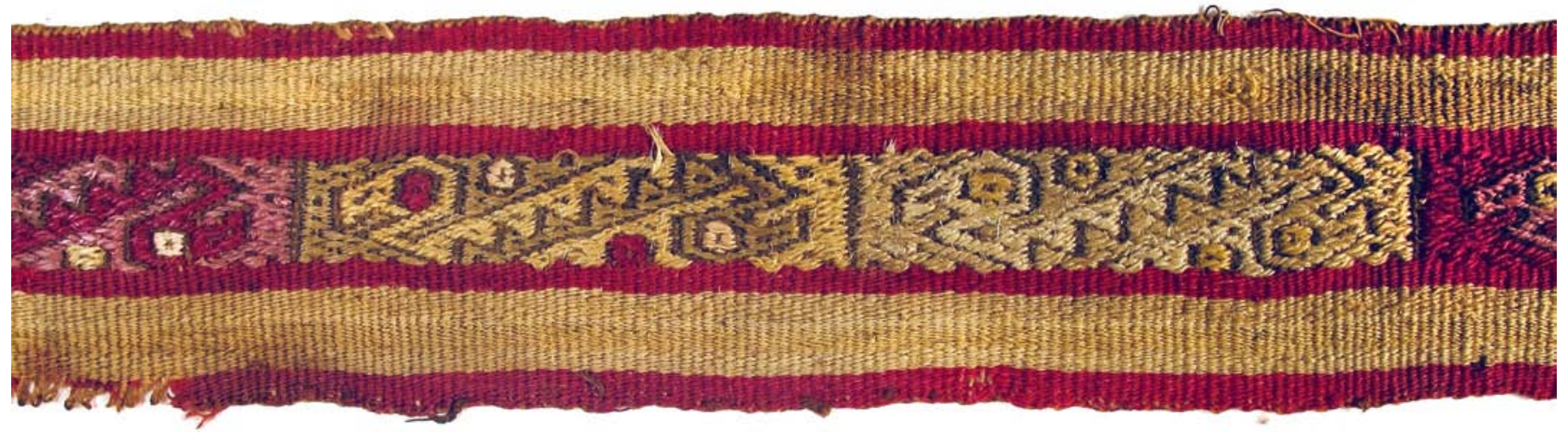

\section{Museum number: V 9.282}

Item: Fragment of a band

Style: Central Coast

Size: $5 \times 30 \mathrm{~cm}$

Material/technique: The textile is in weft rep and supplimentary weft weave. The warp is on the short side. The warp is cotton $2 \mathrm{~S}$ and the weft camelid fiber $2 \mathrm{~S}$. The threadcount is $8 \times 46$ per $\mathrm{cm}$.

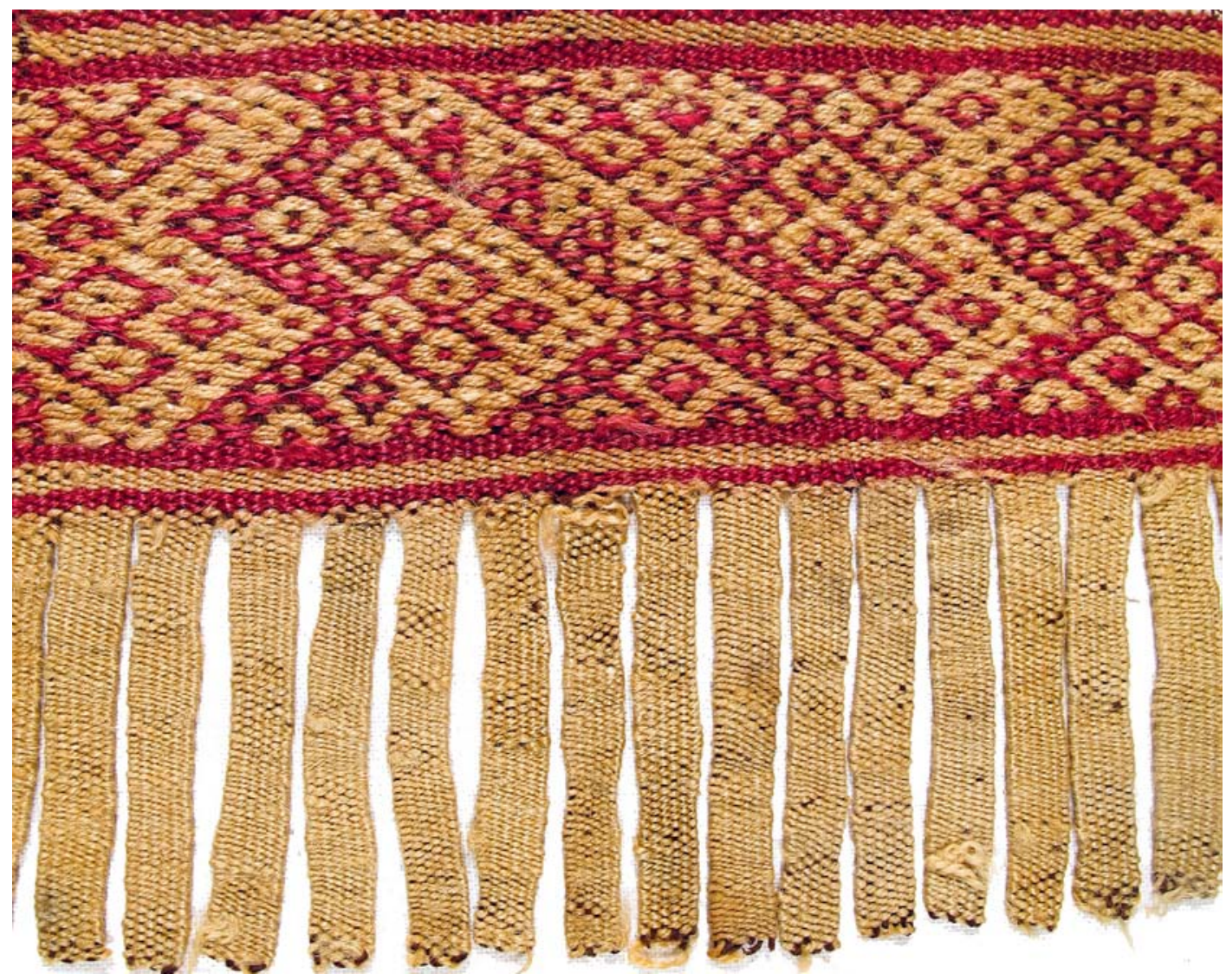

\section{Museum number: V 9.305}

Item: Fragment

Style: Central coast

Size: $9 \times 29 \mathrm{~cm}$

Material/technique: The textile is in 3 panels: $6,16,7 \mathrm{~cm}$ wide - all with weft selvedges and at fringe-bottom one warp-selvedge. Upper $5 \mathrm{~cm}$ : complementary weft weave (lancée); lower part $5 \mathrm{~cm}$ woven fringes, 0,6 $\mathrm{mm}$ wide.

Warp cotton 2S, weft camelid fiber 2S. 


\section{Museum number: V 9.324}

Item: Closed bag

Style: Central Coast

Size: $15 \times 59 \mathrm{~cm}$ (bag $15 \times 15 \mathrm{~cm}$, fringe $45 \mathrm{~cm}$ )

Material/ technique: Plain weave in cotton 2S. The threadcount is $5 \times 5$ per $\mathrm{cm}$. The straps are two 3-braided bands of $15 \mathrm{~cm}$ each, sewn to the upper corners of the bag and tied to each other.

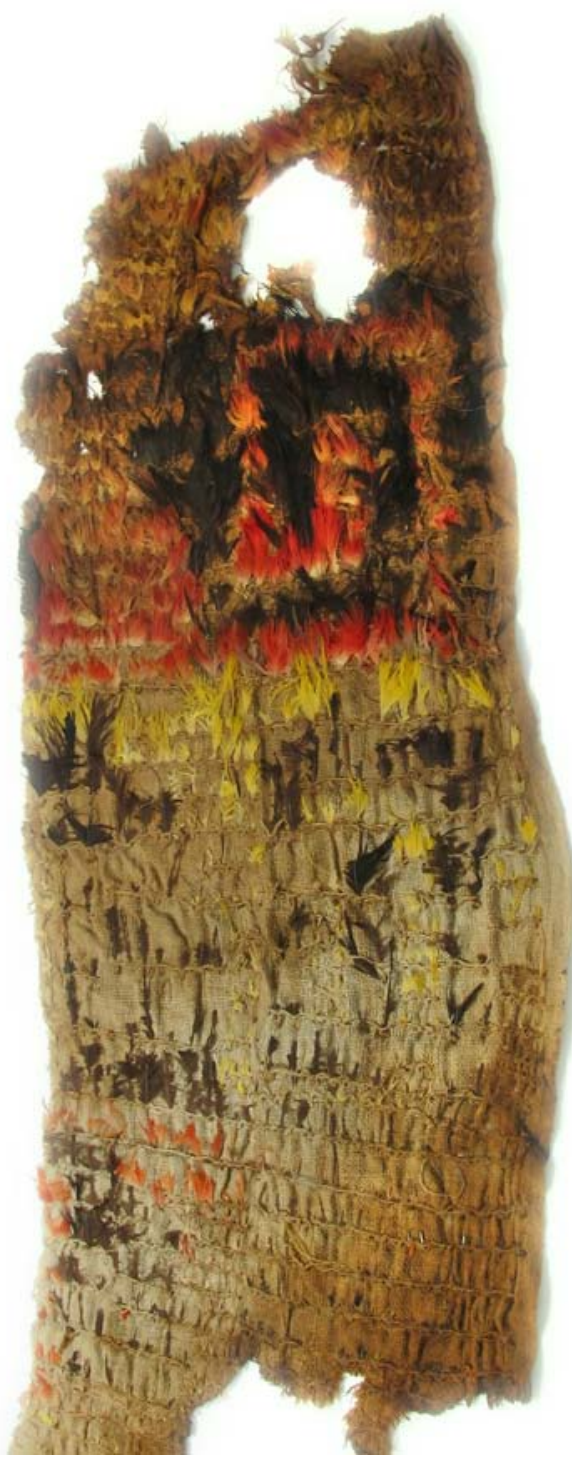

\section{Museum number: V 9.326}

Item: Feather textile, Maybe back piece for hat???

Style: Central Coast

Size: $73 \times 29 \mathrm{~cm}$

Material/ technique: Plain weave in cotton with warp in $2 \mathrm{~S}$ and weft in $\mathrm{Z}$. The threadcount is $9 \times 9$ per $\mathrm{cm}$. There are two side selvedges.

Rows of feather fringes are stitched on every $2 \mathrm{~cm}$. The sewing thread is cotton $2 \mathrm{~S}$.

V 9.325 is a fragment of the same textile.

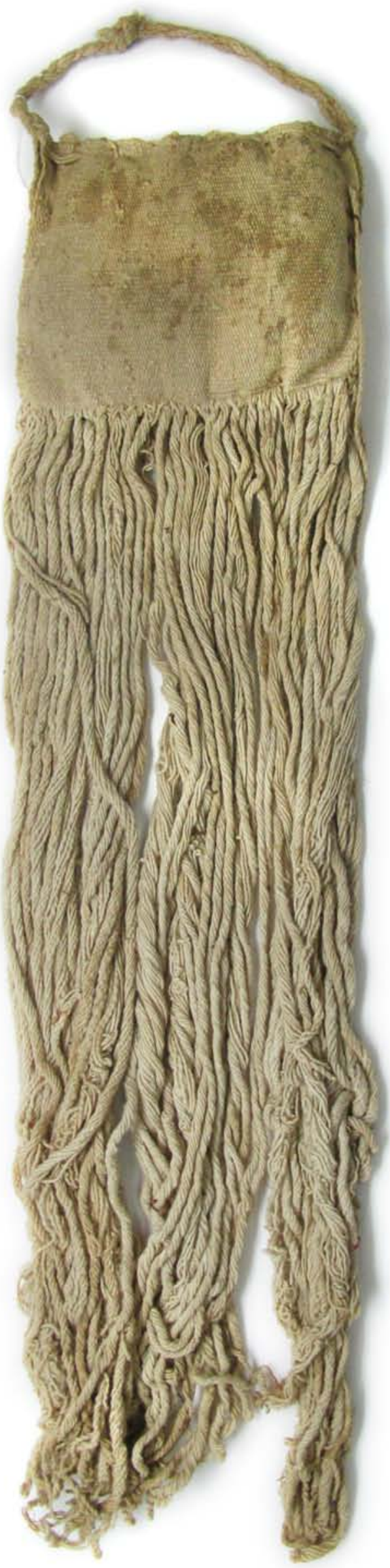




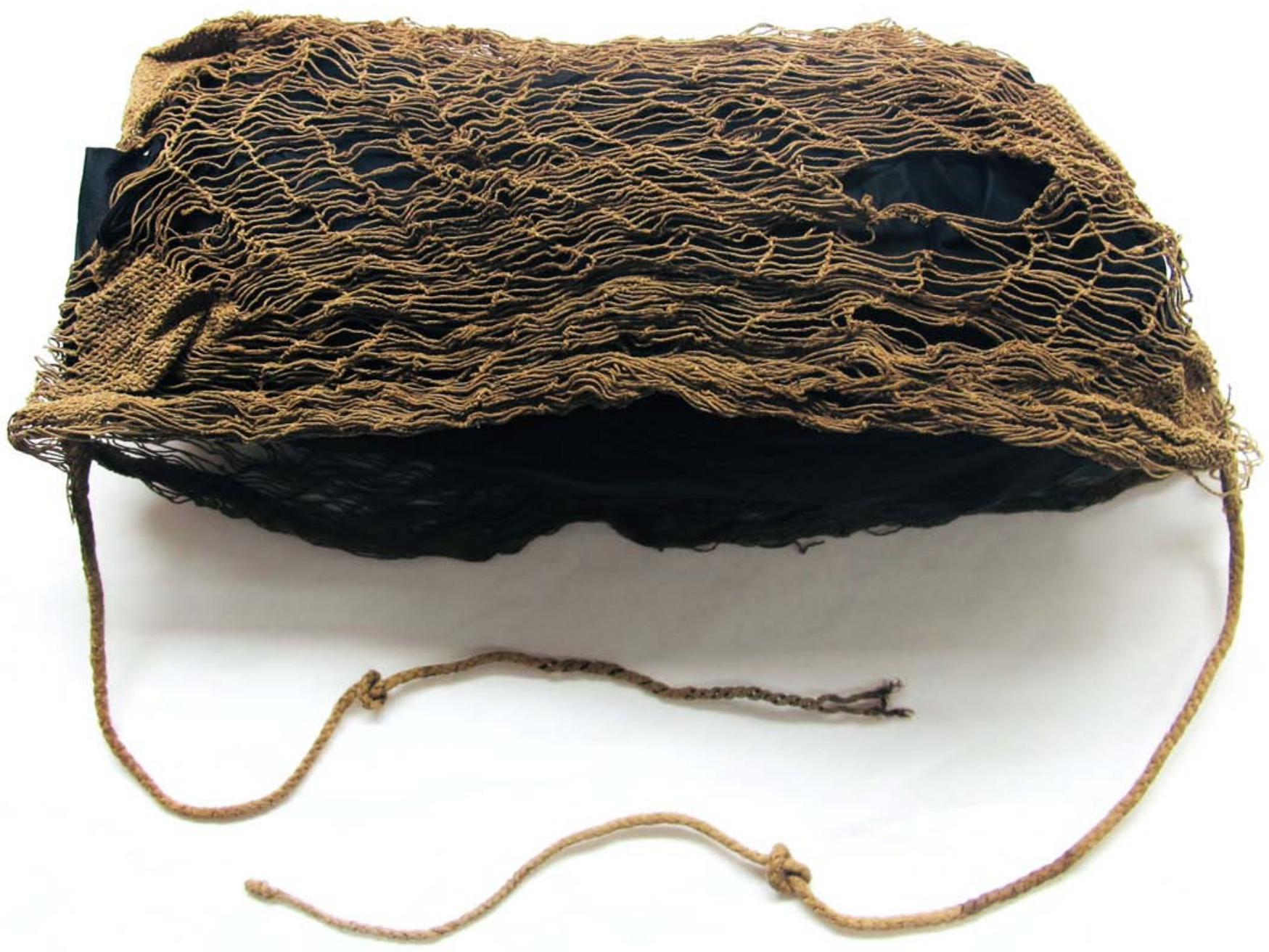

\section{Museum number: V 9.342}

Item: Hairnet

Style: Central Coast

Size: $21 \times 10 \mathrm{~cm}$

Material/technique: Knotted hairnet (lark's knots) with 4-8 strands braided tying bands. Material is plantfiber (Fourcraea andina).

Bibliography: Pre-Columbian Hairnets in the Museum of Ethnology in Berlin, Baessler-Archiv, 2010, Vol. 58, p39-51. 13p.

Lena Bjerregaard, Pre-Columbian Textiles in the Ethnological Museum in Berlin, 2017, https:// digitalcommons.unl.edu/zeabook/52/, pp. 157-159. 


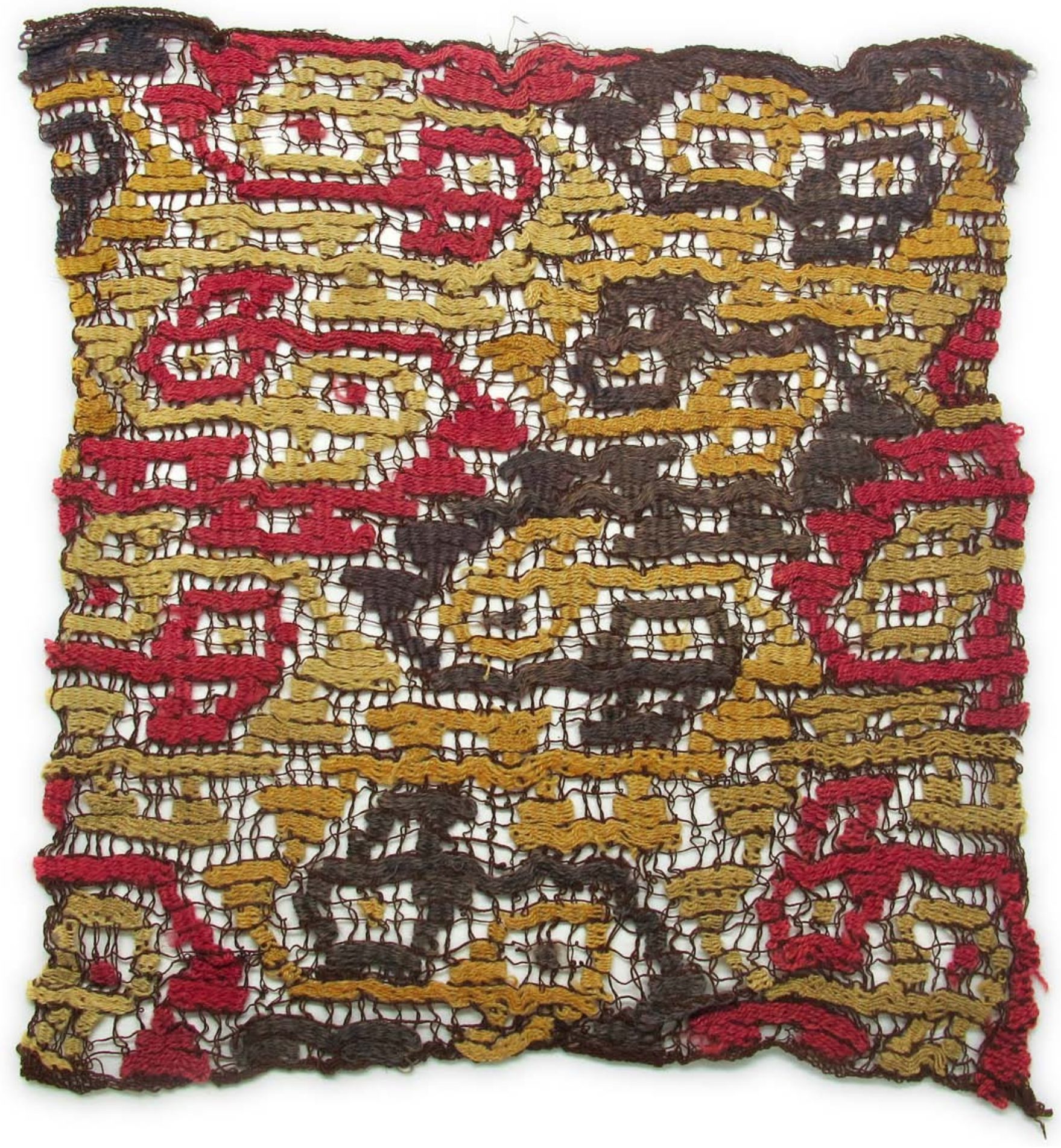

\section{Museum number: V 9.600}

Item: Complete textile

Style: Central coast

Size: $32 \times 32 \mathrm{~cm}$

Material/technique: The textile is complete with 4 selvedges. It is woven in gauze weave with brocaded patterns.

All yarns are camelid fiber $2 \mathrm{~S}$. 


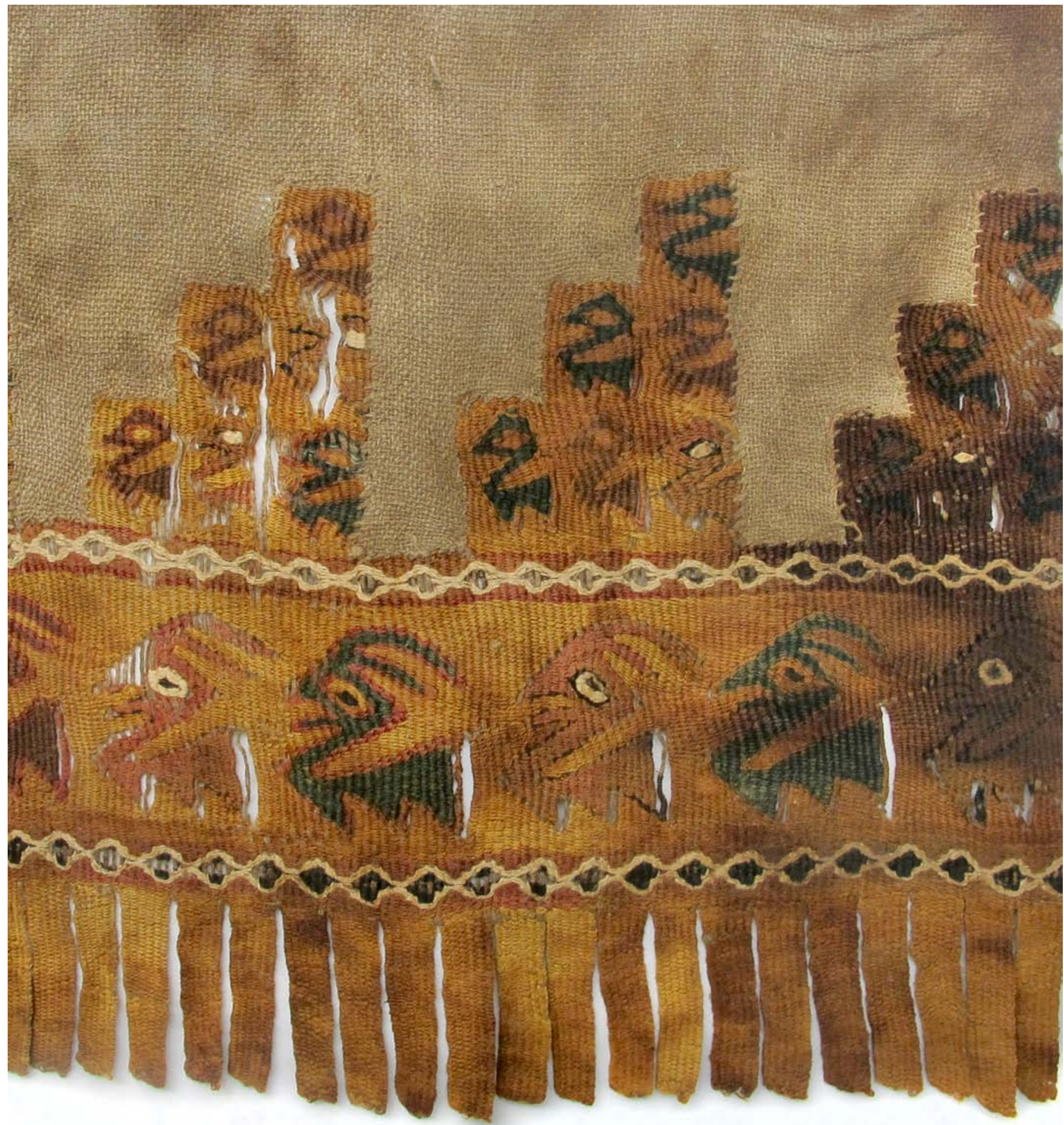

\section{Museum number: V 10.187}

Item: Fragment (of a tunic)

Style: Central coast

Size: $22 \times 57 \mathrm{~cm}$

Material/technique: The textile is the lower edge of a tunic. The textile has warp selvedge at bottom and at both sides weft selvedges. It has at bottom $0,8 \mathrm{~cm}$ wide woven fringes.

The basic material is plain weave cotton. Both warp and weft are $2 \mathrm{~S}$. The threadcount is $16 \times 14$ per $\mathrm{cm}$.

The lower part has slit tapestry over two plain weave cotton warps and with 254 -camelid fiber wefts per $\mathrm{cm}$. 


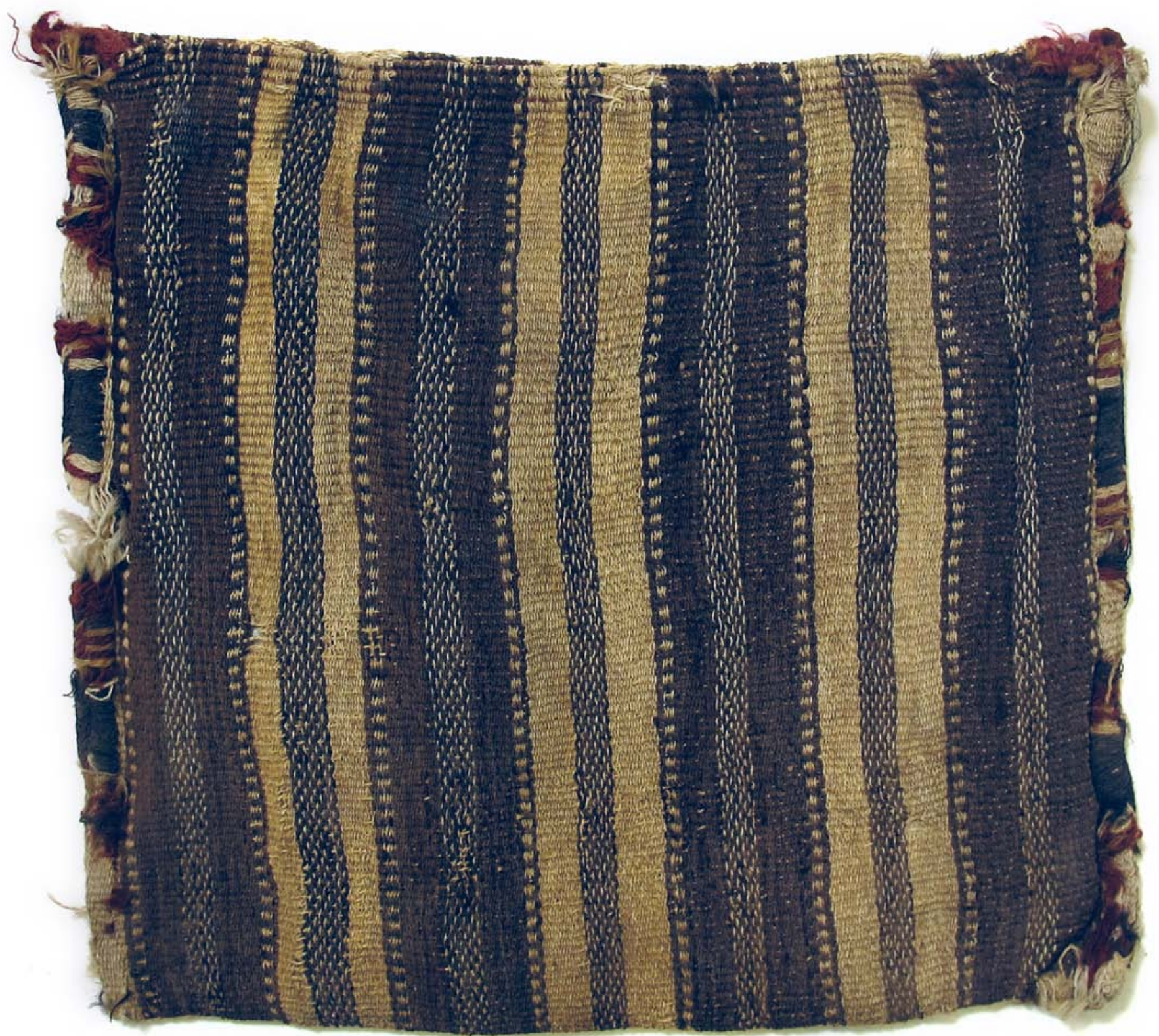

\section{Museum number: V 11.261}

Item: Bag

Style: Central coast

Size: $18 \times 20 \mathrm{~cm}$

Material/technique: The bag is warp faced plain weave with camelid fiber $2 S$ in both warp and weft. The threadcount is $36 \mathrm{x} 6$ per cm. At the weft edges the two layers of the bag are connected with a multicolor striped loopstitch embroidery. 


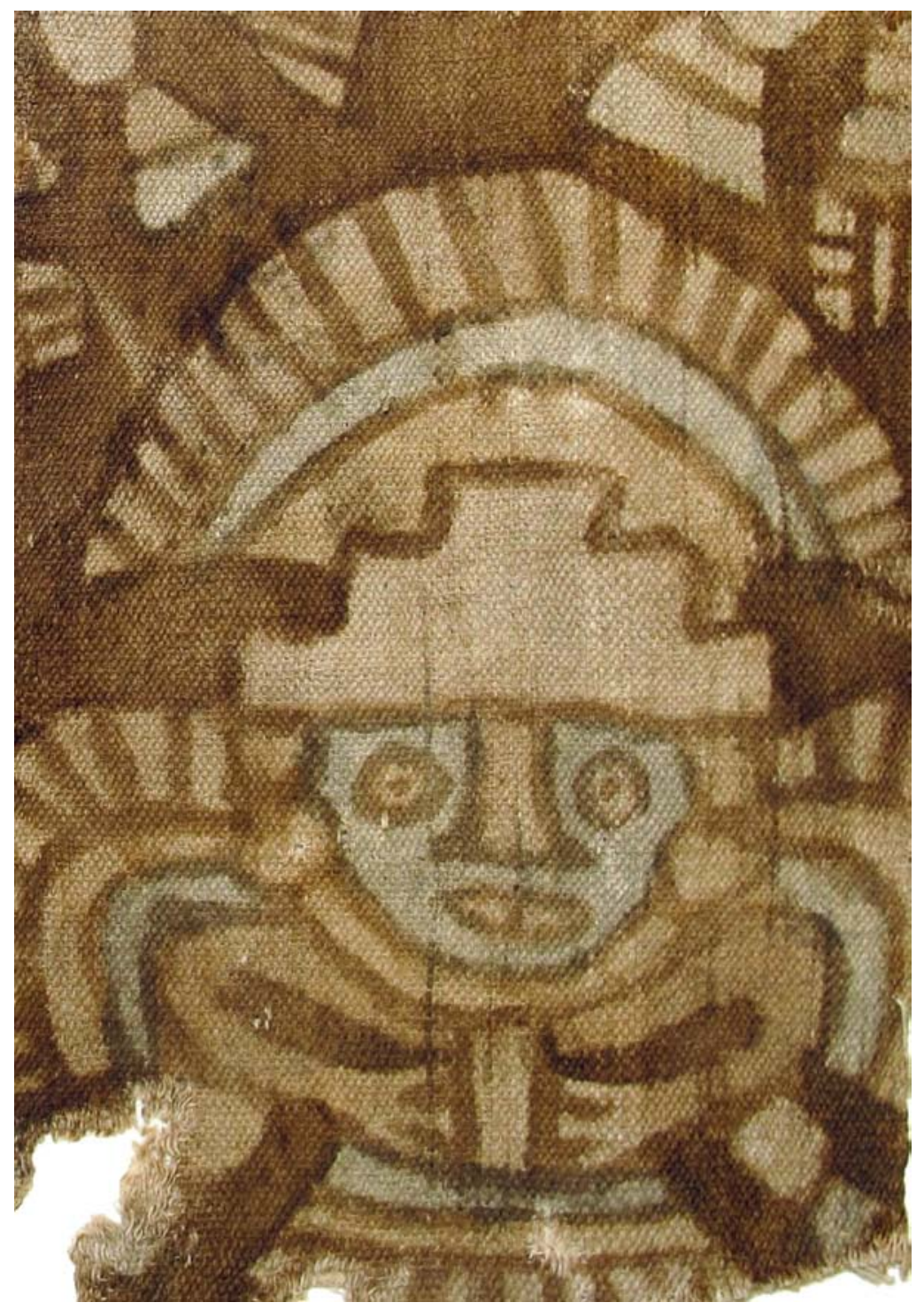

\section{Museum number: V $\mathbf{8 . 9 5 5}$}

Item: Fragment

Style: North Coast

Size: $26 \times 38 \mathrm{~cm}$

Material/technique: Plain weave, painted (nothing on back side) textile fragment. All yarns are cotton S. Warp is paired and the weft is single. The threadcount is 11 (paired) $\times 9$ per $\mathrm{cm}$.

\section{Museum number: V 8.960}

\section{Item: Fragment}

Style: North coast

Size: $32 \times 43 \mathrm{~cm}$

Material/technique: Plain weave cotton with the warp $S$ and the weft $Z$. The threadcount is $9 \times 9$ per $\mathrm{cm}$. The textile is painted and has two side selvedges.

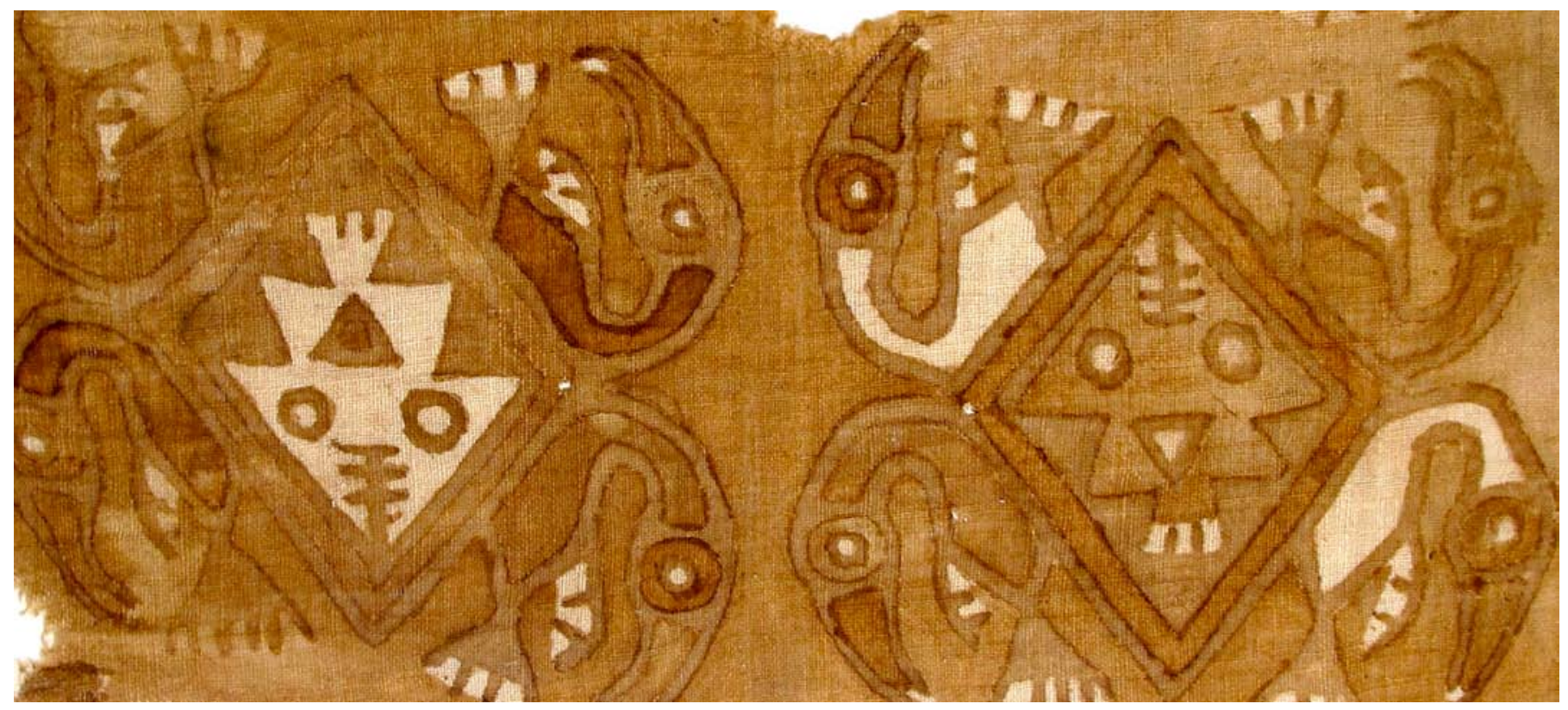




\section{Museum number: V 8.973}

Item: Textile (complete)

Style: North Coast

Size: $59 \times 43 \mathrm{~cm}$

Material/technique: The textile is woven in slit tapestry. The warp is cotton $2 \mathrm{Z}$ and the weft camelid fiber $2 \mathrm{~S}$. The threadcount is $6 \times 28$ per $\mathrm{cm}$. The textile has two side selvedges and one warp selvedge. It has loose warps (fringe) at the other end.

\section{Museum number: V 8.959}

\section{Item: Bag}

\section{Style: North Coast}

Size: $19 \times 19 \mathrm{~cm}$

Material/technique: The textile has supplementary weft patterning (lancée). Warp and weft are paired cotton $S$ and the pattern-weft is $2 \mathrm{~S}$ camelid fiber. The threadcount is $14 \times 9$ (both paired) per $\mathrm{cm}$. The bag has four selvedges. It is folded along the warp and the two side selvedges are sewn together.
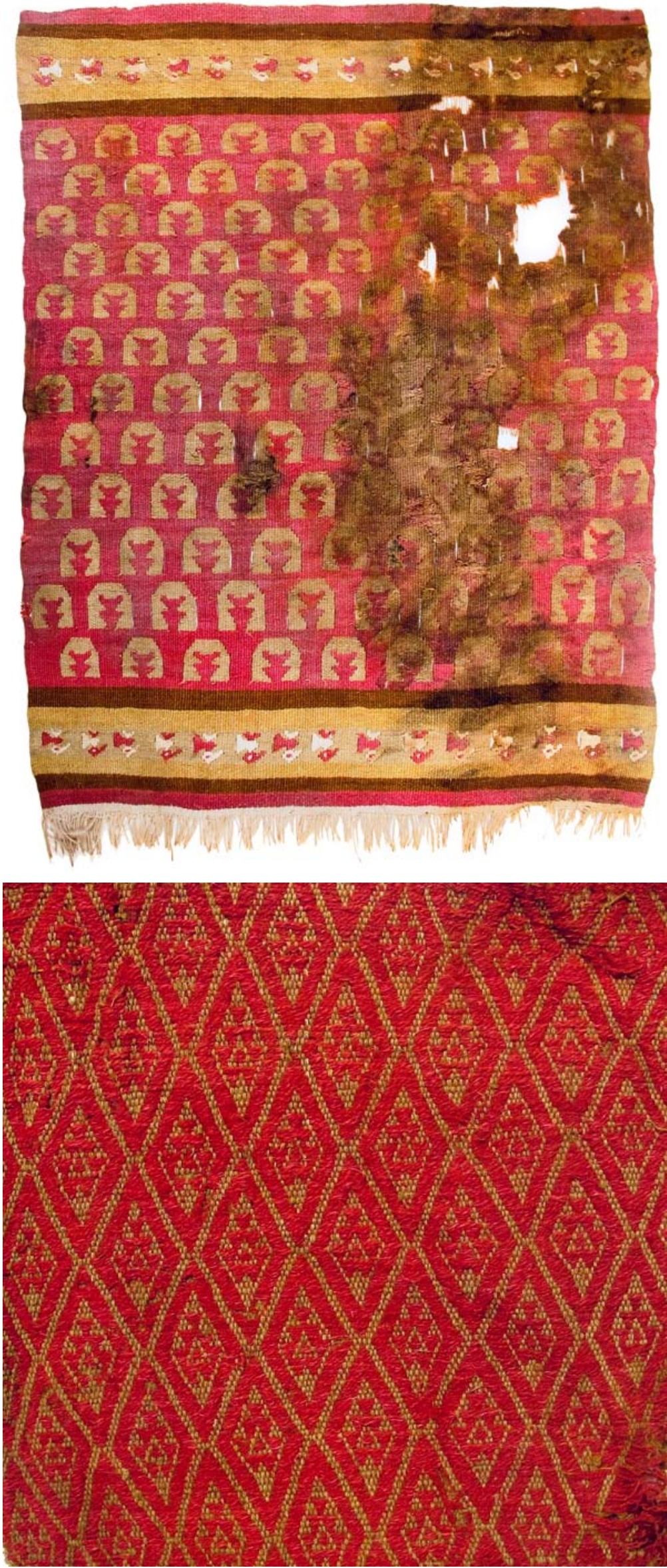

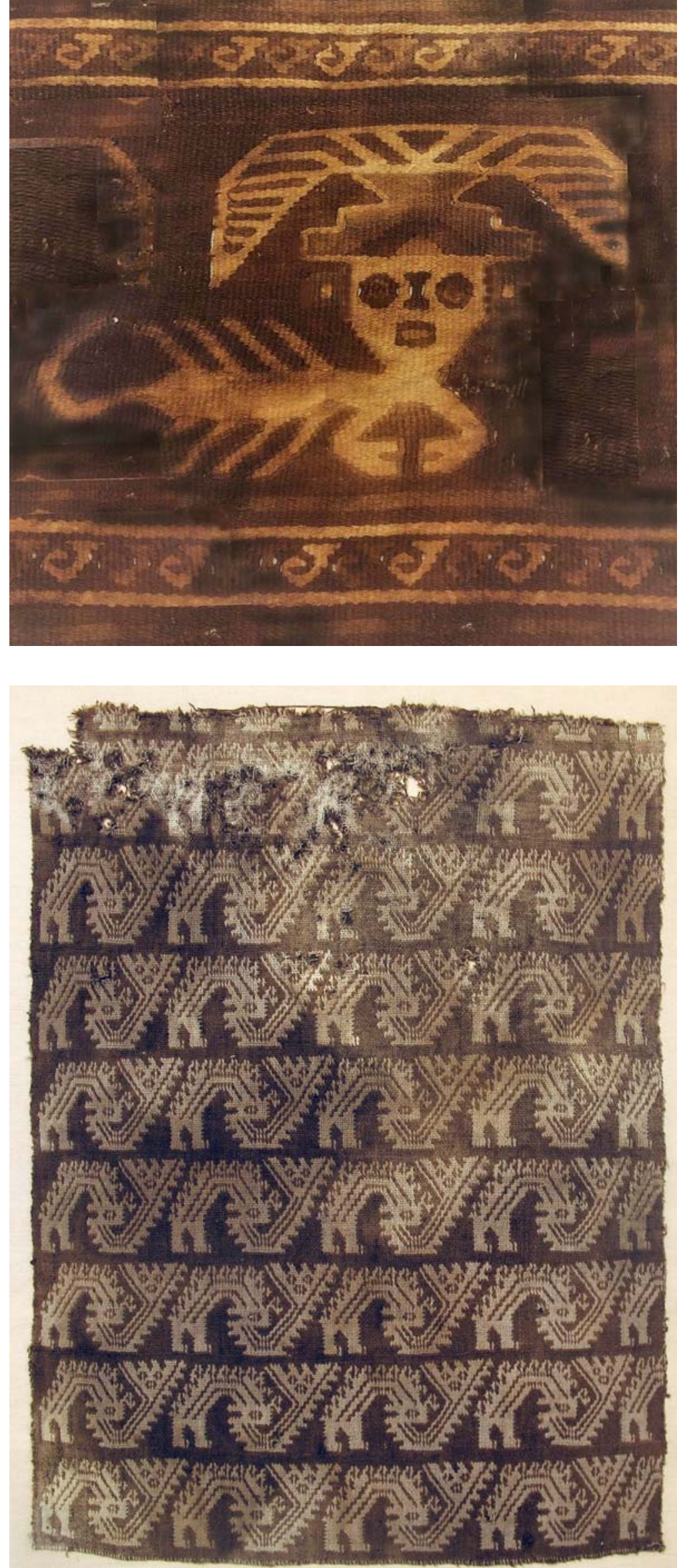

\section{Museum number: V $\mathbf{8 . 9 8 1}$}

Item: Fragment

Style: Central Coast

Size: $21 \times 20 \mathrm{~cm}$

Material/technique: Dovetailed tapestry weave with warps and wefts in cotton $2 \mathrm{~S}$. The warps are replied in $\mathrm{Z}$ from two different colored $2 \mathrm{~S}$ yarns. The threadcount is $7 \times 40$ per $\mathrm{cm}$.

Further description: At the bottom of the fragment is a warp selvedge, and at top (over the upper stripe) the warps are loose (not being woven). The image is of high status (feather crown) lobster or scorpion.

\section{Museum number: V 9.001}

Item: Fragment

Style: North Coast

Size: $30 \times 40 \mathrm{~cm}$

Material/technique: The textile is woven in doubleweave. It has cotton Z warp and S weft. The threadcount is (in every layer) $12 \times 10$ per $\mathrm{cm}$.

There are two weft selvedges and one warp selvedge. 


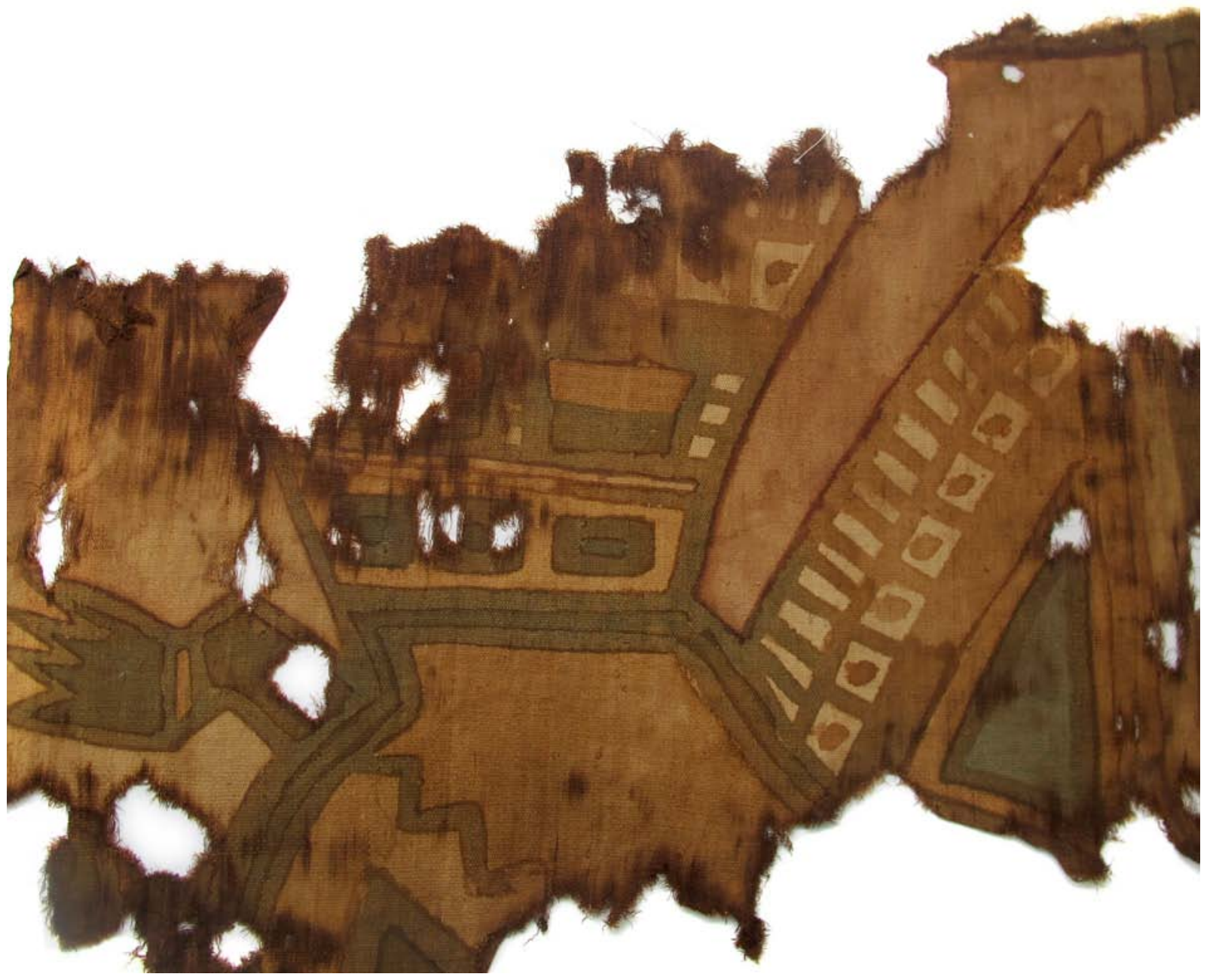

Museum number: V 9.003 + V 9.126

Item: 2 fragment of the same textile. Style: North Coast

Size: V 9.003: 45 x 55 cm, V 9.126: 53 $x 53 \mathrm{~cm}$

Material/technique: The textile is woven in plain weave. It has cotton $S$, paired warps and paired wefts. The threadcount is $28 \times 9$ per $\mathrm{cm}$.

The textile is painted. Both textiles have fragments of weft selvedges.

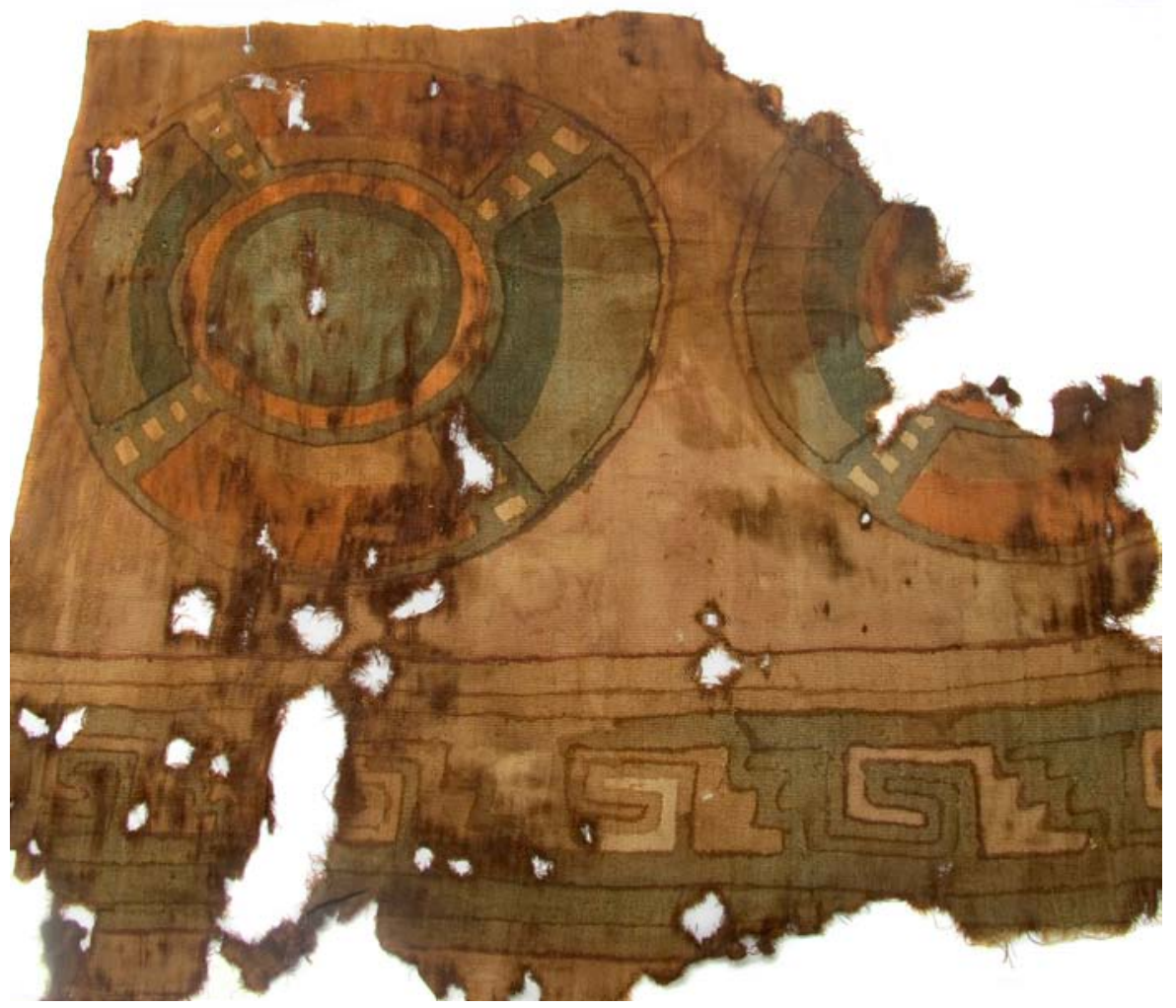



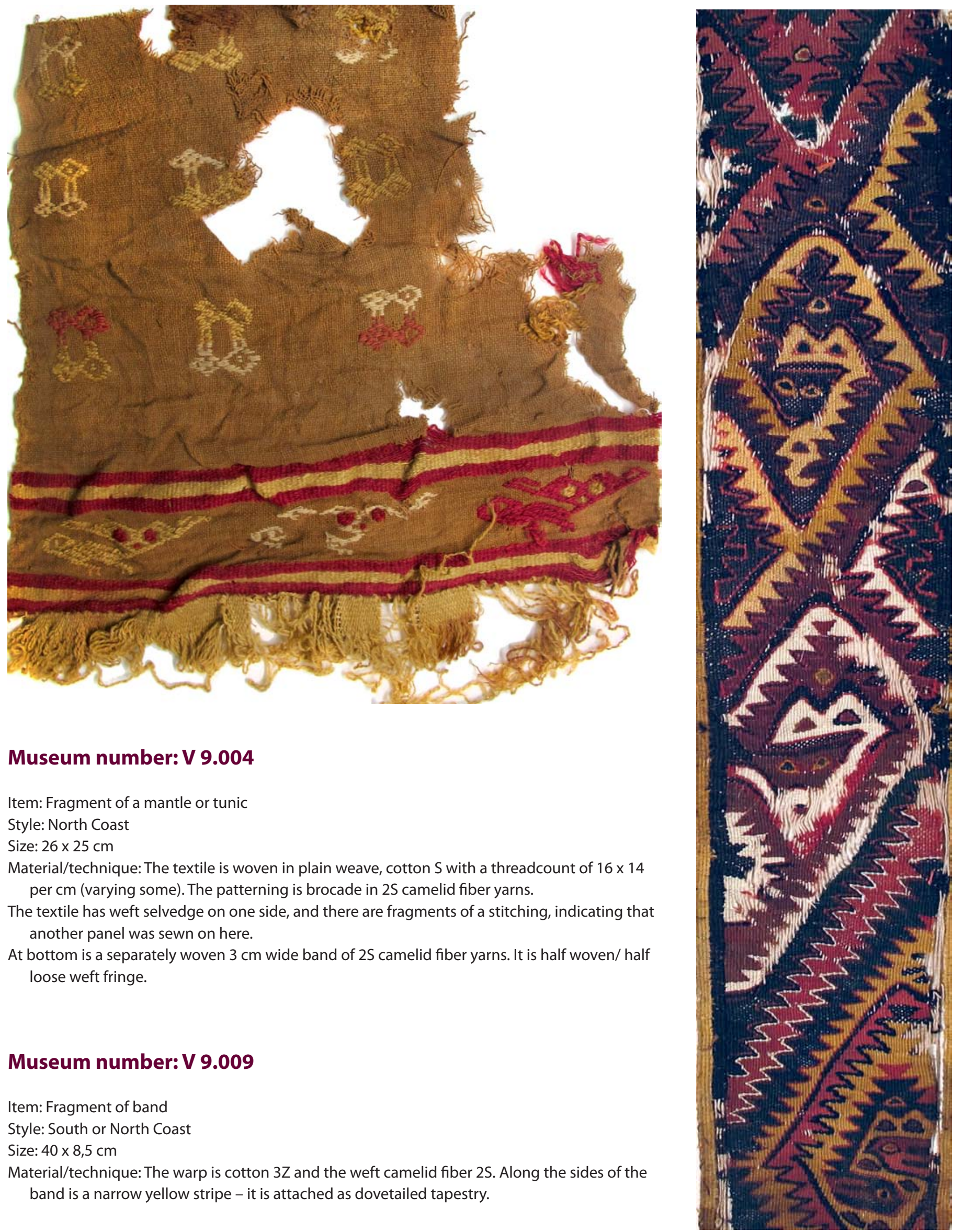

Item: Fragment of a mantle or tunic

Style: North Coast

Size: $26 \times 25 \mathrm{~cm}$

Material/technique: The textile is woven in plain weave, cotton S with a threadcount of $16 \times 14$ per $\mathrm{cm}$ (varying some). The patterning is brocade in $2 \mathrm{~S}$ camelid fiber yarns.

The textile has weft selvedge on one side, and there are fragments of a stitching, indicating that another panel was sewn on here.

At bottom is a separately woven $3 \mathrm{~cm}$ wide band of $2 \mathrm{~S}$ camelid fiber yarns. It is half woven/ half loose weft fringe.

\section{Museum number: V 9.009}

Item: Fragment of band

Style: South or North Coast

Size: $40 \times 8,5 \mathrm{~cm}$

Material/technique: The warp is cotton $3 \mathrm{Z}$ and the weft camelid fiber $2 \mathrm{~S}$. Along the sides of the band is a narrow yellow stripe - it is attached as dovetailed tapestry. 


\section{Museum number: V 9.021}

Item: Fragment

Style: North coast

Size: $17,5 \times 12 \mathrm{~cm}$

Material/technique: A textile woven in tapestry with warp cotton $3 Z$ and weft $2 S$ camelid fiber. The threadcount is $8 \times 40$ per $\mathrm{cm}$.

\section{Museum number: V 9.035 and V 9.230}

Item: Two fragments

Style: North Coast

Size: V 9.230: $20 \times 23 \mathrm{~cm}$, V 9.035: $19 \times 17 \mathrm{~cm}$

Material/technique: A textile woven in tapestry with warp cotton $\mathrm{S}$ and weft camelid fiber $2 S$. The threadcount is $9 \times 32$ per $\mathrm{cm}$.

Both fragments are cut on all sides (no selvedges).
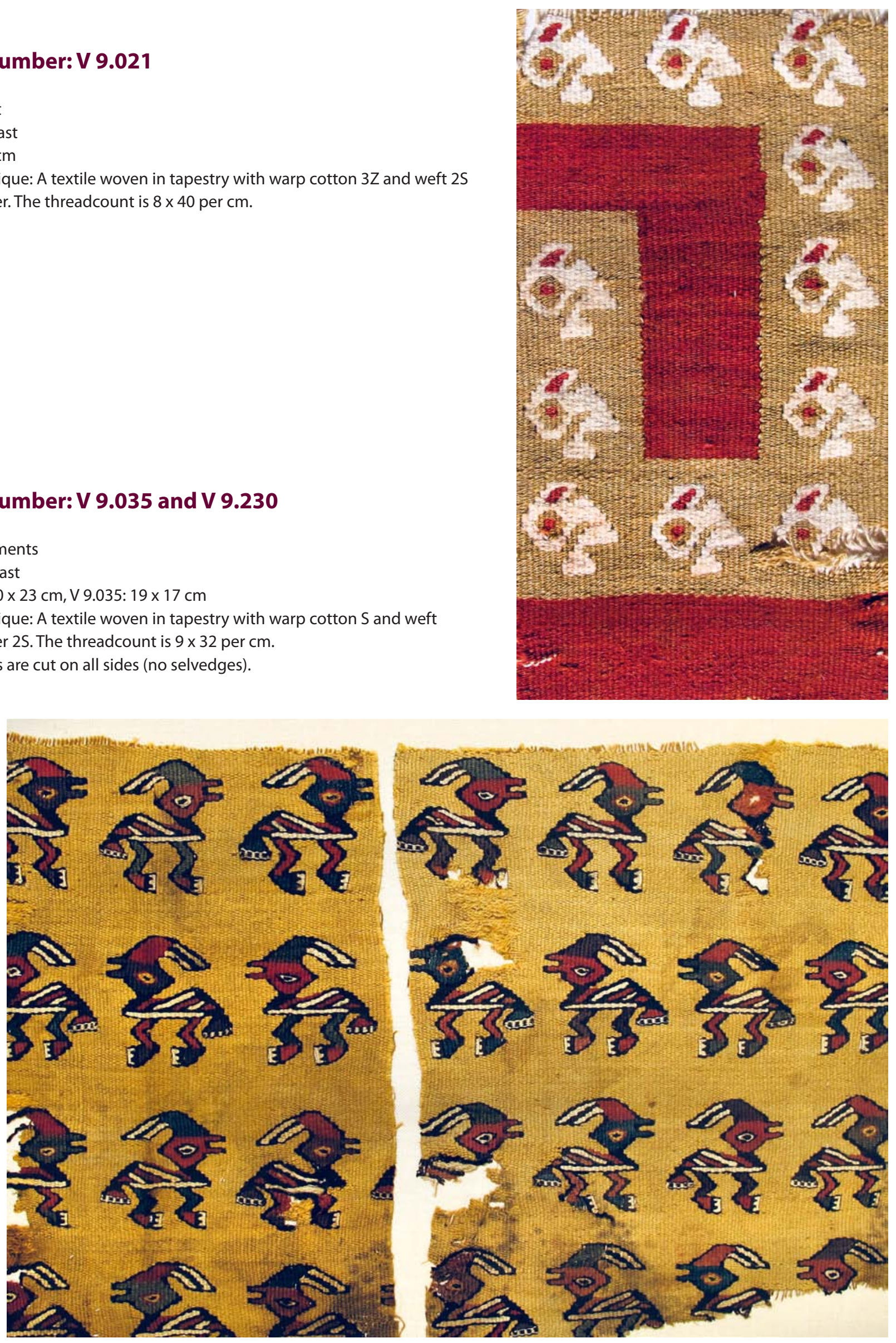


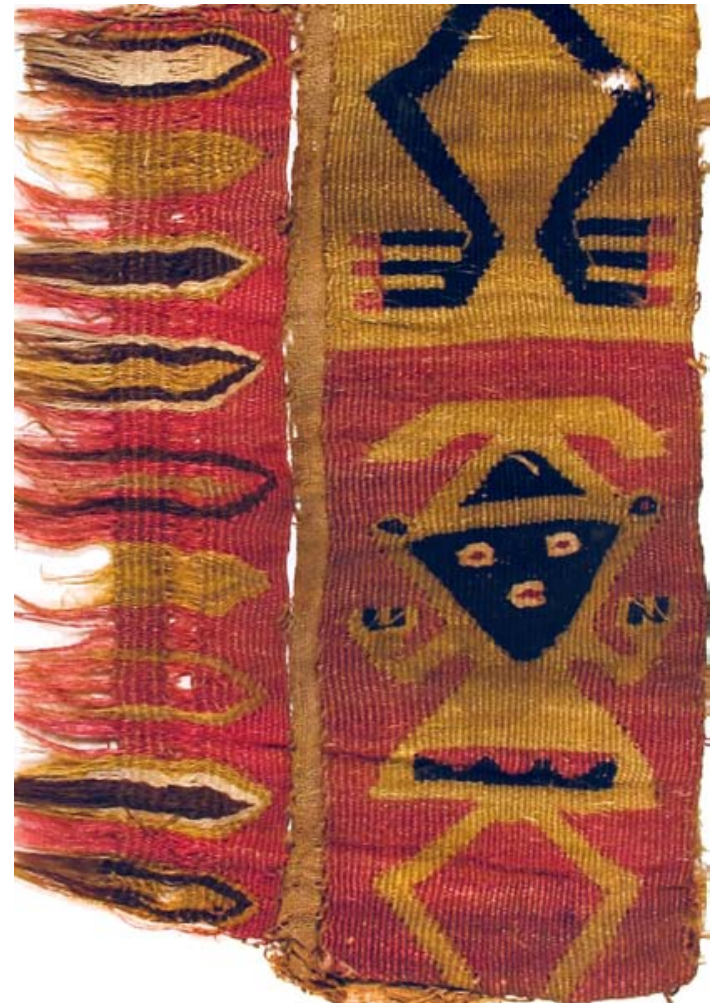

\section{Museum number: V 9.068}

Item: Fragment

Style: Central/ North Coast

Size: $21 \times 13 \mathrm{~cm}$

Material/technique: Bottom edge of a tunic.

1. At bottom is a $5 \mathrm{~cm}$ wide weft-fringe band with tapestry and cut fringe. The warp is $2 Z$ cotton and the weft is $2 S$ camelid fiber.

2. $A 7 \mathrm{~cm}$ wide tapestry band with $2 Z$ cotton warp and $2 S$ camelid fiber weft. The band has two weft selvedges.

3. On the backside of this tapestry is a plain weave textile in cotton $\mathrm{S}$ (both warp and weft) - threadcount $15 \times 12$ per $\mathrm{cm}$ - which was probably the foundation material of the tunic. This cloth has warp selvedge at bottom.

\section{Museum number: V 9.074}

Item: Fragment

Style: North coast

Size: $13 \times 17 \mathrm{~cm}$

Material/technique: The textile is in plain weave cotton S. The threadcount is $14 \times 20$ per $\mathrm{cm}$. The patterning is in brocade with $2 \mathrm{~S}$ camelid fiber wefts.

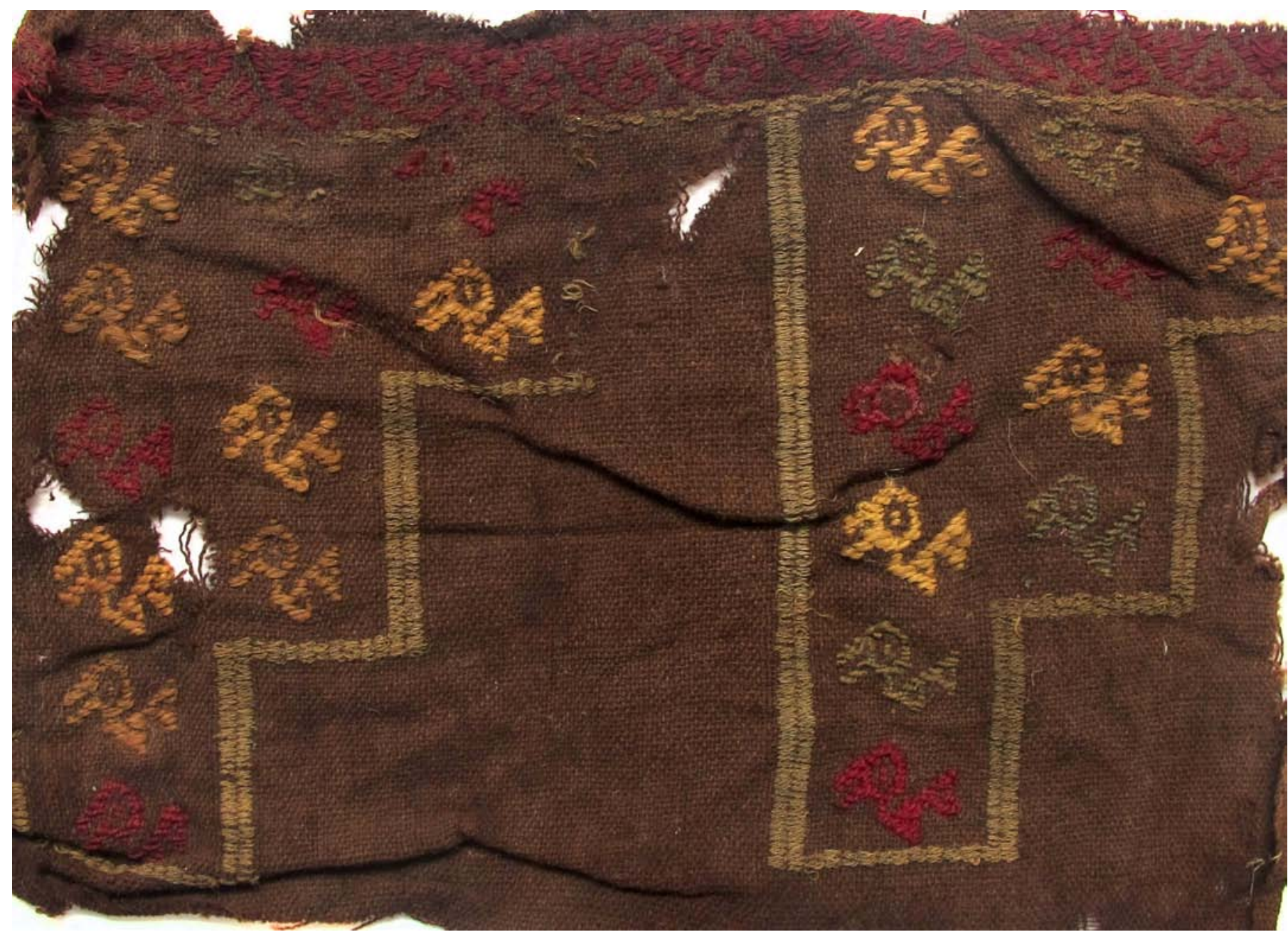




\section{Museum number: V 9.075}

Item: Complete textile

Culture: South or Central Coast

Size: $42 \times 29 \mathrm{~cm}$

Material/technique: The textile has four selvedges. The warp is $2 \mathrm{~S}$ cotton and the wefts are camelid fiber $2 \mathrm{~S}$.

The techniques are brocade, tapestry and weft rep. The threadcount is $9 \times 36$ per $\mathrm{cm}$ (in weft-rep).

At warp ends are fragments of loopstitch embroidery.

Along one weft selvedge are fragments of a plain weave cotton material stitched on.

\section{Museum number: V 9.132}

Item: Complete textile

Culture: Central/North-coast

Size: $48 \times 45 \mathrm{~cm}$

Material/technique: Complete textile with 4 selvedges woven in plain weave. Both weft and warp are cotton S. The warp is in some places paired and in some places single.

At the sides are red/brown warps of $2 \mathrm{~S}$ camelid fiber.

The textile is complete with 4 selvedges.
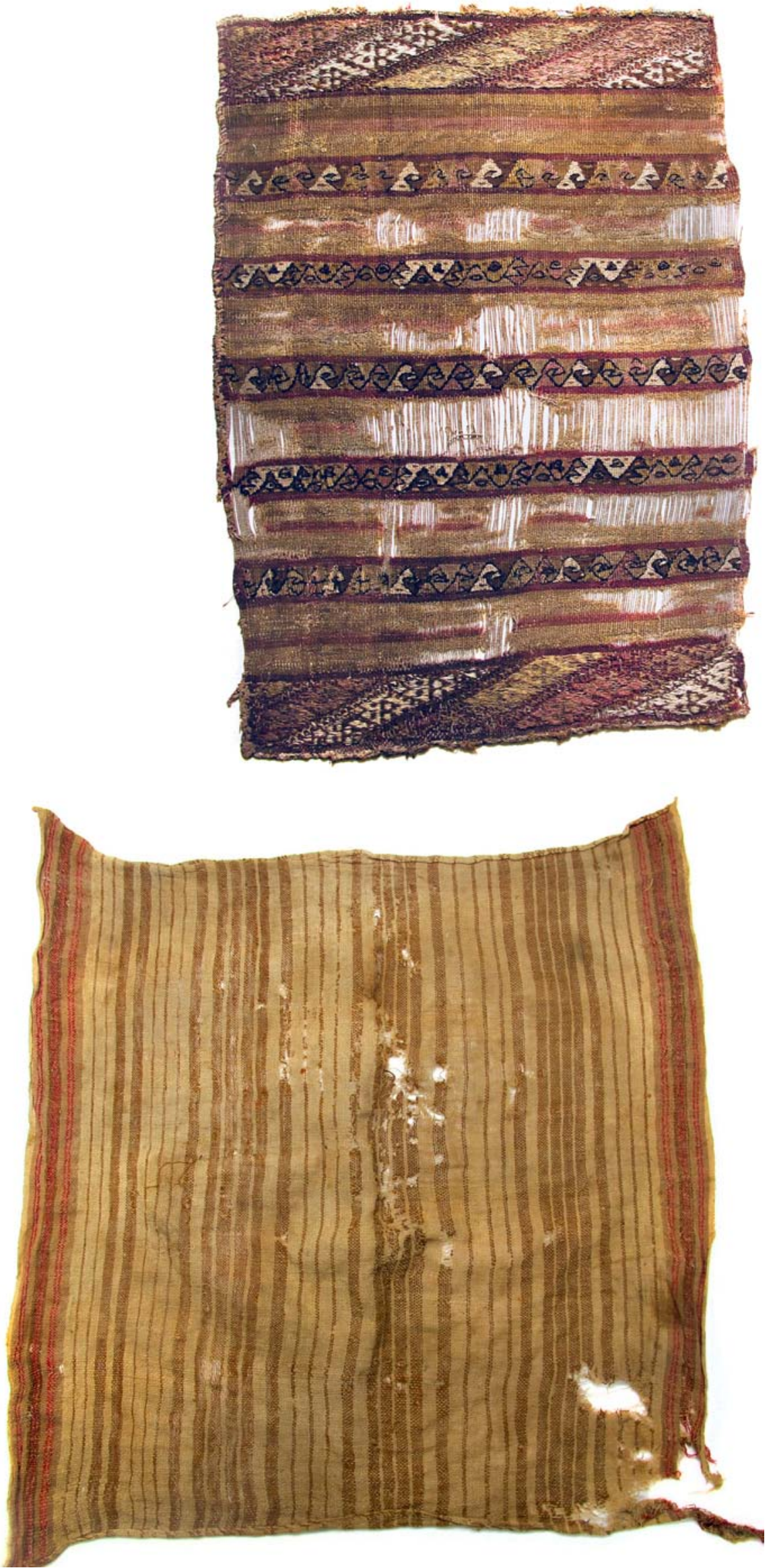


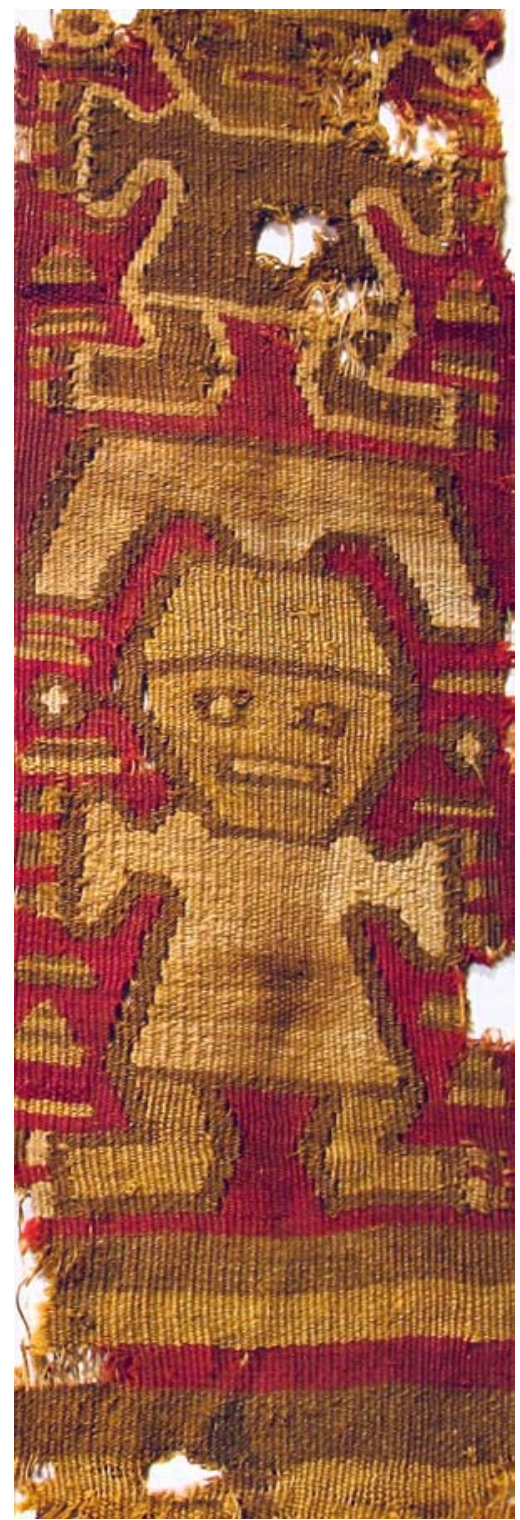

\section{Museum number: V 9.122}

Item: Fragment of a band.

Style: North Coast, Chimu

Size: 35 x $10 \mathrm{~cm}$

Material/technique: The band has weft selvedges and no warp selvedges.

It is woven in slit tapestry. The warp is cotton $2 \mathrm{Z}$ and the weft is camelid fiber $2 \mathrm{~S}$ and paired cotton $Z$. The threadcount is $8 \times 36$ per $\mathrm{cm}$.

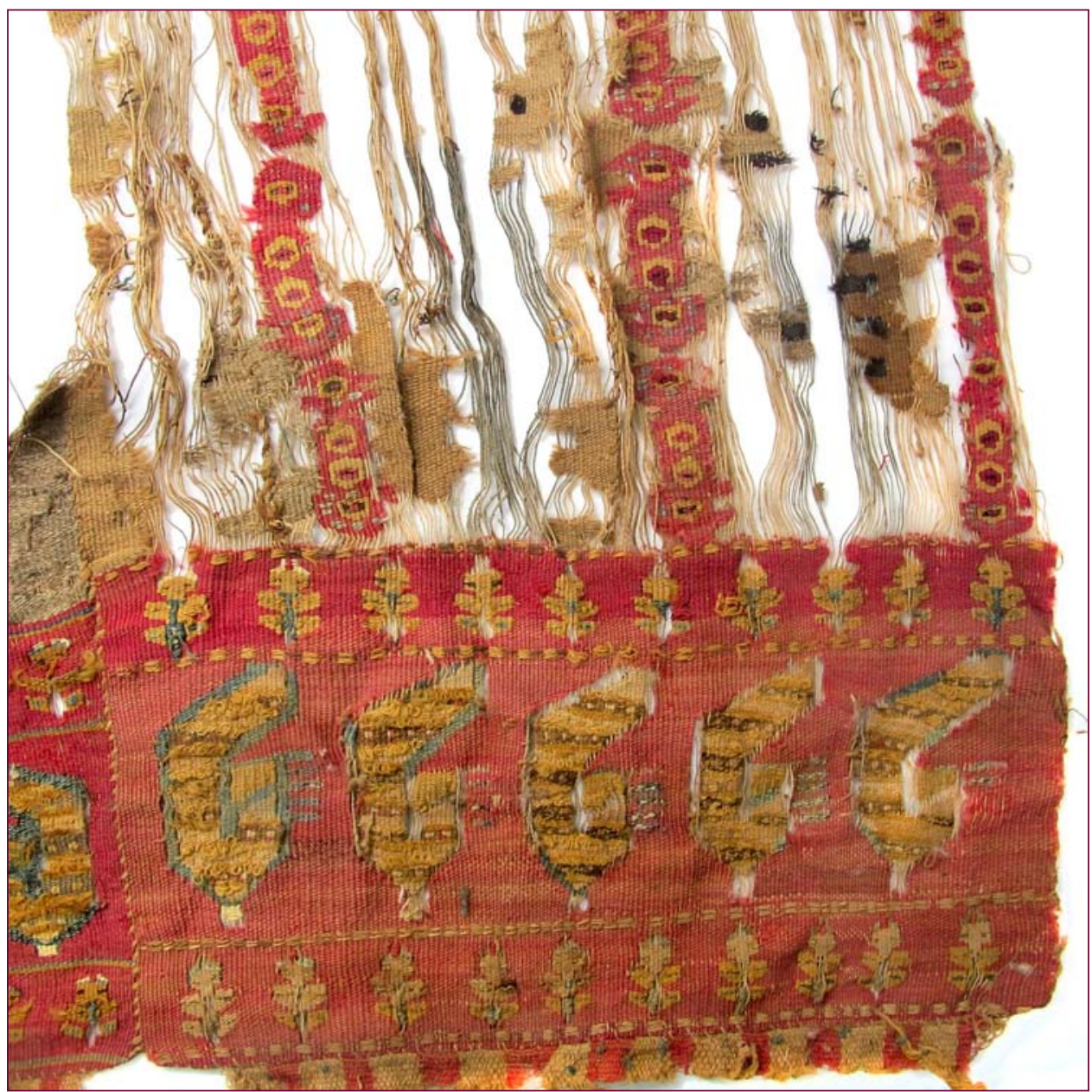

Item: Fragment of a tunic (?)

Style: North coast

Size: $90 \times 66 \mathrm{~cm}$

Materia/technique: Dove tailed tapestry, warp cotton 2Z, weft camelid fiber 2S. Part of the pattern has looped floss.

The textile consist of 3 panels - each $27 \mathrm{~cm}$ wide. All 3 panels have at bottom warp-selvedge, and 2 weft-selvedges.

At bottom a $3 \mathrm{~cm}$ wide band with looped weft fringe - warp lengthwise cotton S, weft camelid fiber $2 \mathrm{~S}$. The band has $2 \mathrm{~cm}$ woven, $1 \mathrm{~cm}$ looped wefts.

This band is stitched on to the textile after the panels have been sewn together - it stretches over the whole textile.

The images with looped floss are maybe cashew nuts? 


\section{Museum number: V 9.143}

Item: Fragments of a large textile

Style: North Coast

Size: $93 \times 72 \mathrm{~cm}$

Material/technique: The textile is in plain weave and is woven in cotton $S$, paired warps and paired wefts. The threadcount is $28 \times 14$ (paired) per $\mathrm{cm}$.

There are fragments of another panel sewn along one weft-selvedge. The textile is very similar to $V 9.148$, but has a different threadcount.

The pattern is painted or printed, and is only at the front side of the textile.

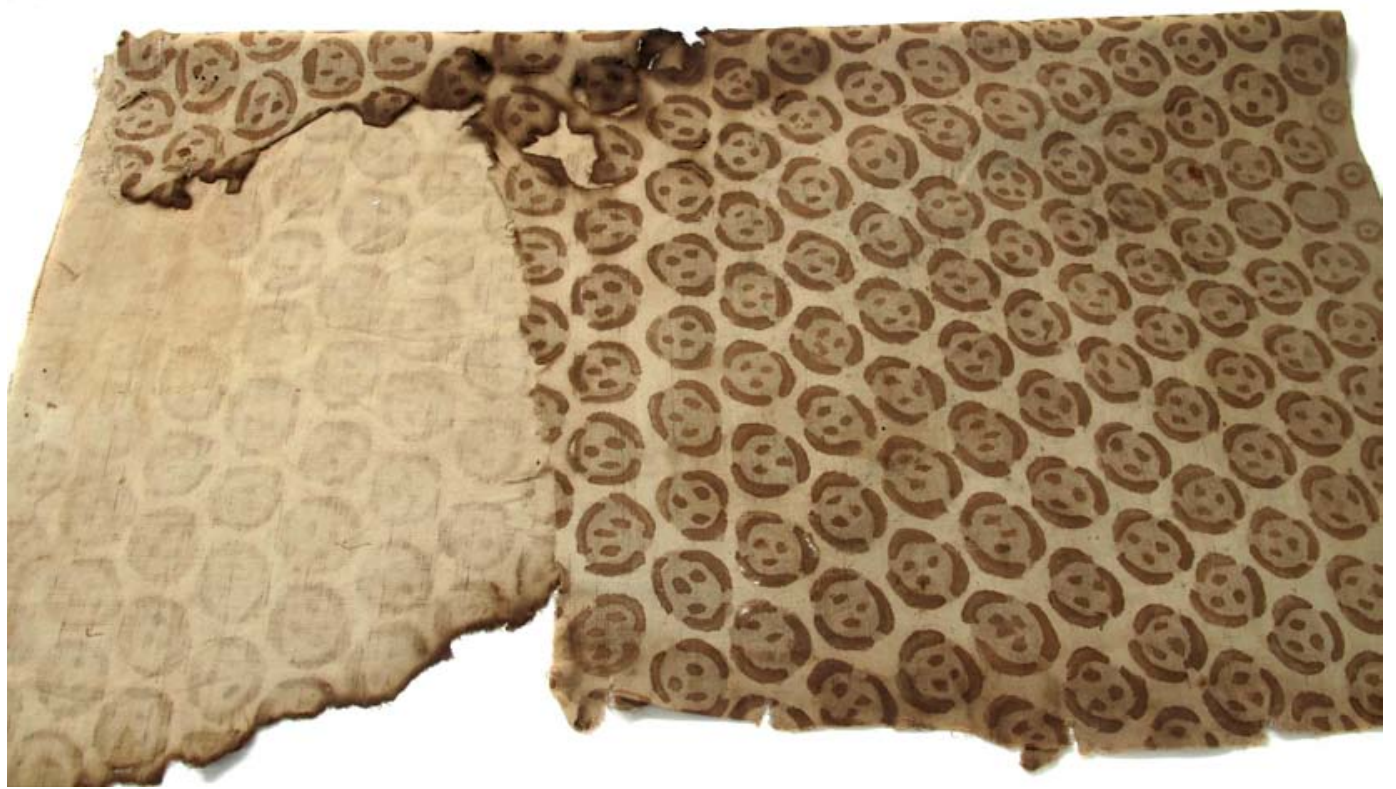

\section{Museum number: V 9.148}

Item: fragment Style: North coast

Size: 97 x $48 \mathrm{~cm}$

Material/technique: The textile is in full warp length with two warpselvedges. A fragment of a second panel is sewn on. It is woven in warp faced plain weave. The threadcount is $18 \times 15$ per $\mathrm{cm}$. It has paired wefts $Z$ and paired warps Z. It is printed or painted. The textile is very similar to V9143 - it has the same painted/

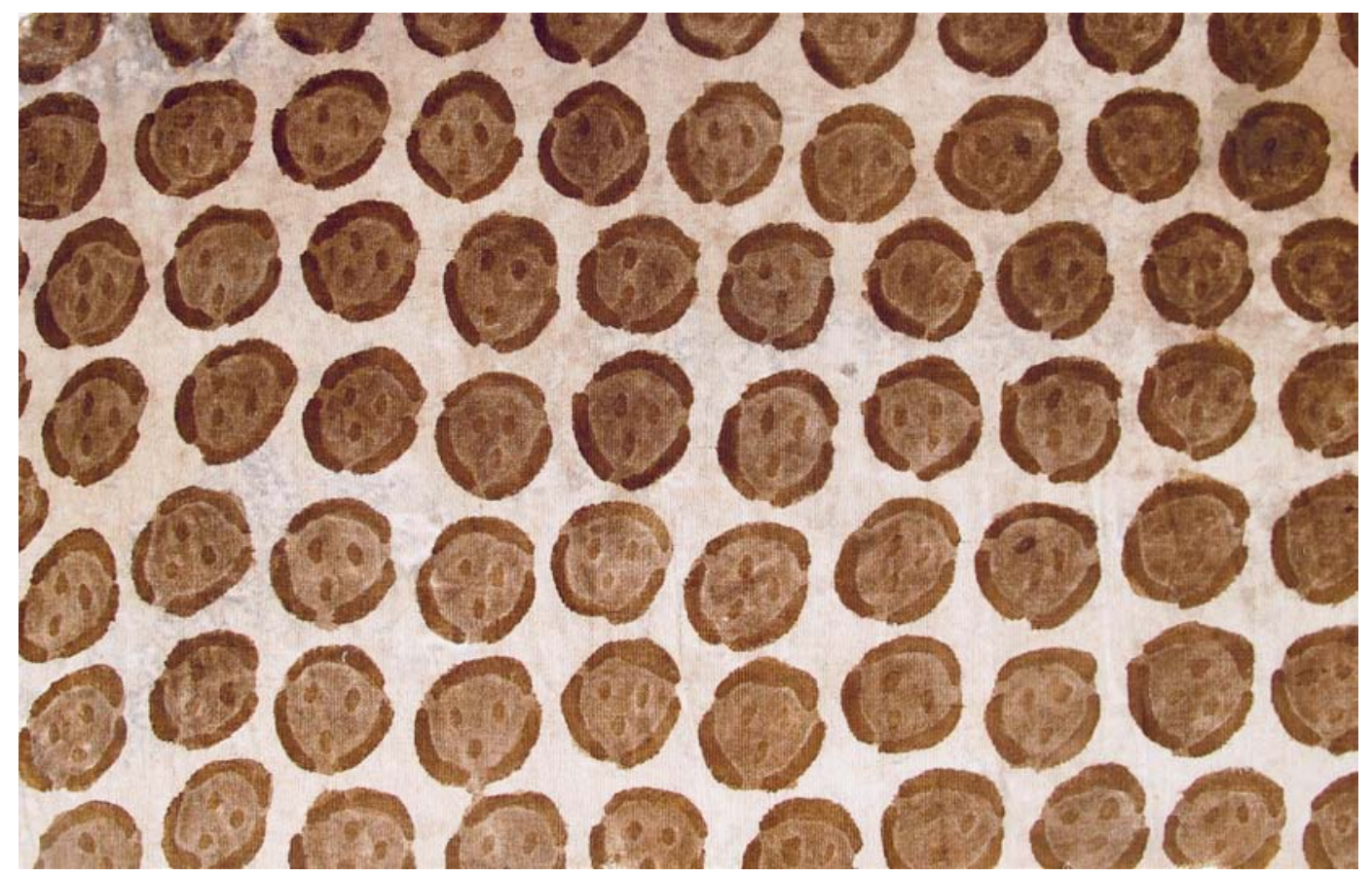
printed pattern, but has a different threadcount, so it is not from the same textile. 


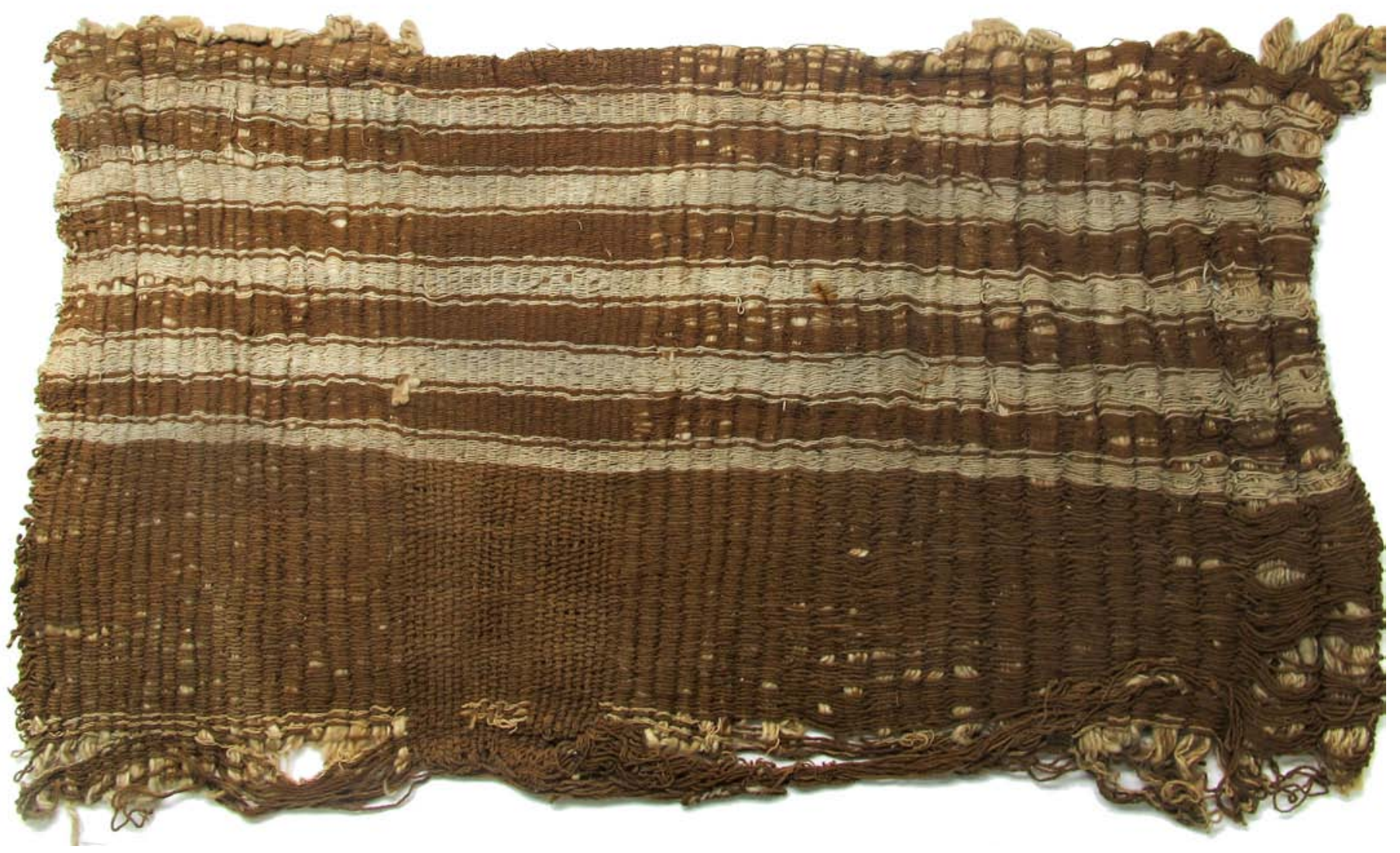

\section{Museum number: V 9.144}

Item: Complete textile

Style: North coast

Size: $57 \times 35 \mathrm{~cm}$

Material/technique: A very coarse textile with 4 selvedges. It is woven in warp faced plain weave - cotton $2 S$ replyed Z with three yarns. The wefts are paired and tripled $Z$ and $2 S$ cotton. The tripled wefts are very thick, maybe the item was a mat to sit on. The threadcount is $3 \times 20$ per $\mathrm{cm}$. 


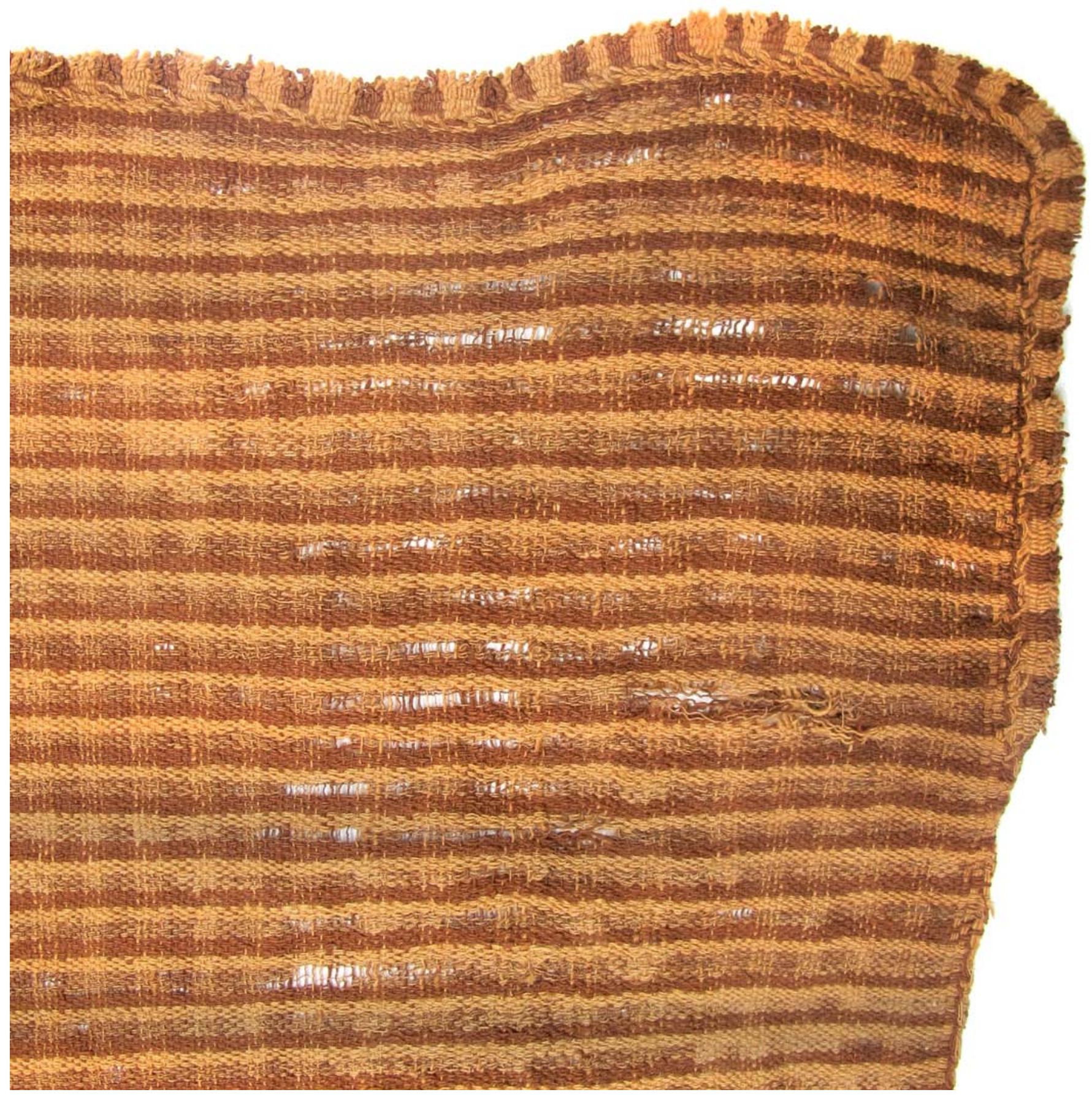

\section{Museum number: V 9.153}

Item: Mantle

Style: North coast

Size: $140 \times 171 \mathrm{~cm}$

Material/ technique: the textile has 3 panels - each one is $57 \mathrm{~cm}$ wide. It is woven in plain weave cotton $\mathrm{S}$, with paired warps and single wefts. The threadcount is 18 (paired) $x 10$ per $\mathrm{cm}$.

The outer weft-sides of the mantle have a woven band attached going just around the corners of the warp-selvedge. This band is $6 \mathrm{~mm}$ wide - it has 3 warps and a tiny $(1 \mathrm{~mm})$ looped weftfringe towards the outside. 


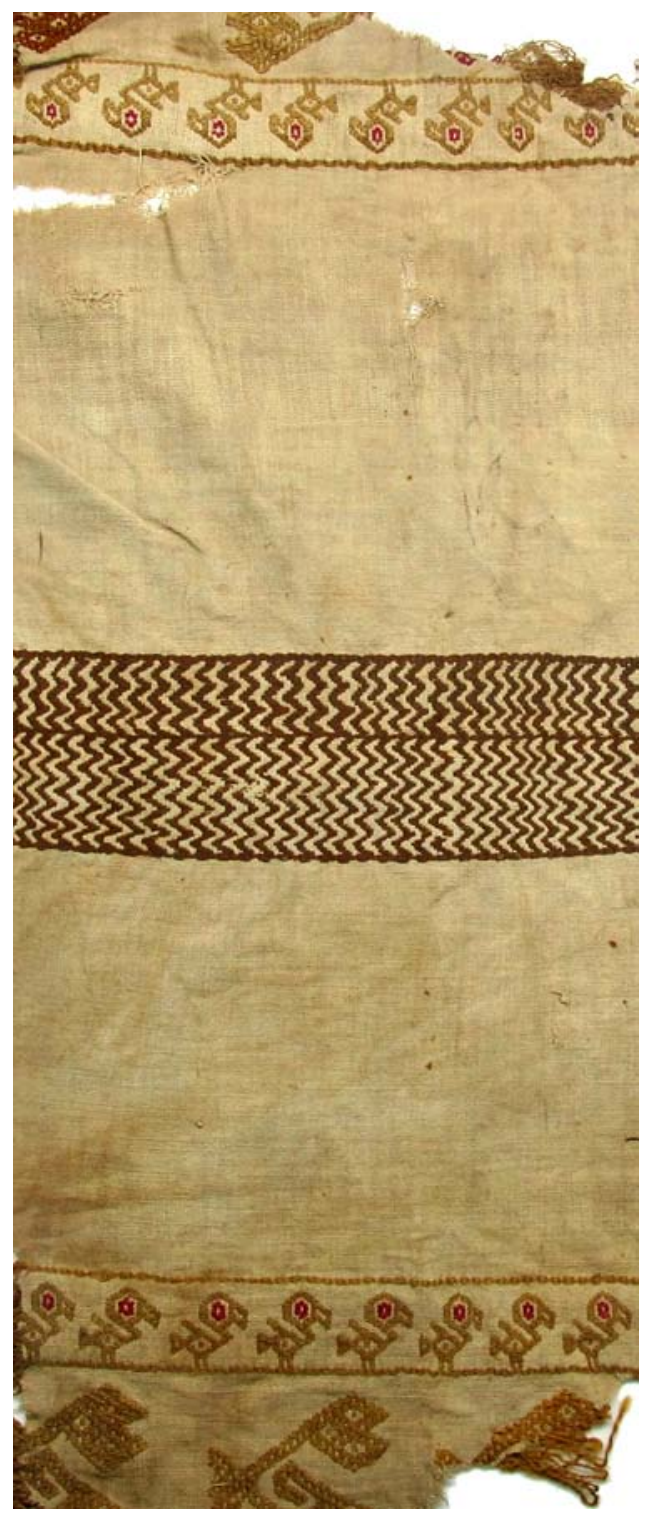

\section{Museum number: V 9.154}

Item: Fragment from tunic.

Style: North coast

Size: $52 \times 30 \mathrm{~cm}$

Material/technique: Shoulderpiece of a tunic. The zigzag stripes are the center shoulderpiece (the side selvedge on the left is either vertical neck opening or left arm hole). The brocaded patterns are oriented opposite each other indicating front and back side and thus it is a shoulder piece.

The textile is woven in plain weave cotton $\mathrm{S}$ (both warp and weft) and the threadcount is $17 \times 15$ per $\mathrm{cm}$.

The brocaded patterns are made with camelid fiber $2 \mathrm{~S}$ yarns.

\section{Museum number: V 9.161}

Item: Textile, scarf.

Style: North coast

Size: $77 \times 90 \mathrm{~cm}$

Material/technique: The textile is woven in cotton $\mathrm{S}$ (both warp and weft) in plain weave with a threadcount of $10 \times 8$. The pattern is made in tie-dye. There are 4 selvedges (one weft-selvedge is fragmented but exists).

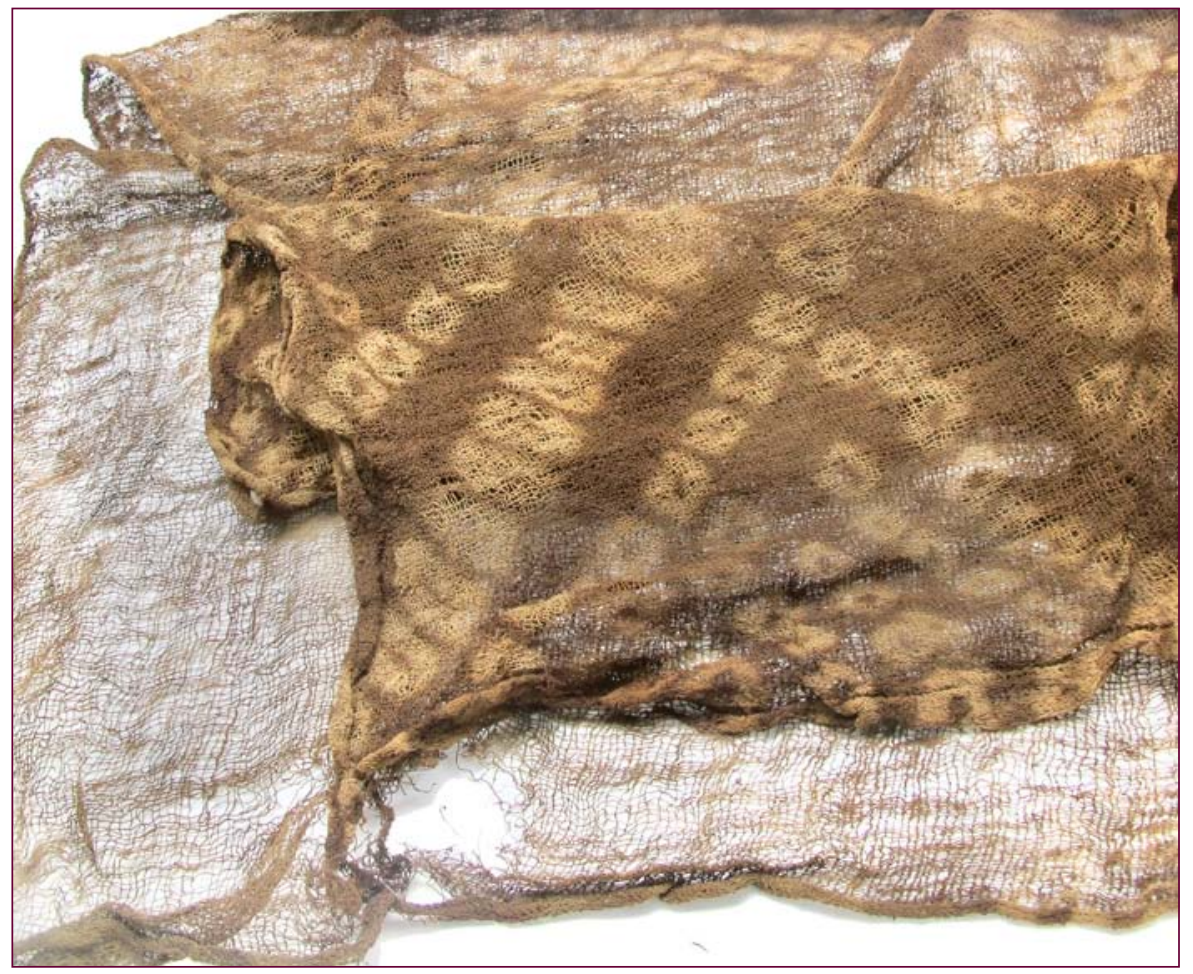




\section{Museum number: V 9.162}

Item: Fragment of a large textile

Style: North coast

Size: Original complete size was around $100 \times 100$. The fragment is a diagonal stripe about $40 \mathrm{~cm}$ wide.

Material/technique: The textile is woven in loose woven plain weave in cotton S. There are fragments of selvedges on all warp and weft sides.
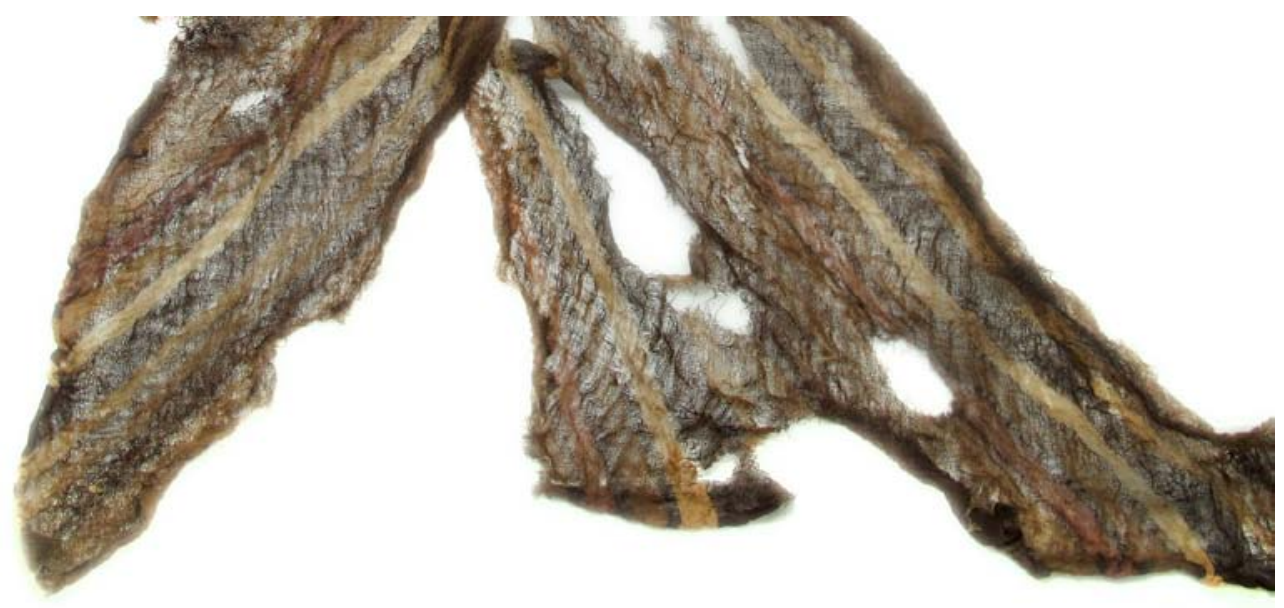

The textile is painted in ca $1-2$ $\mathrm{cm}$ diagonal stripes.

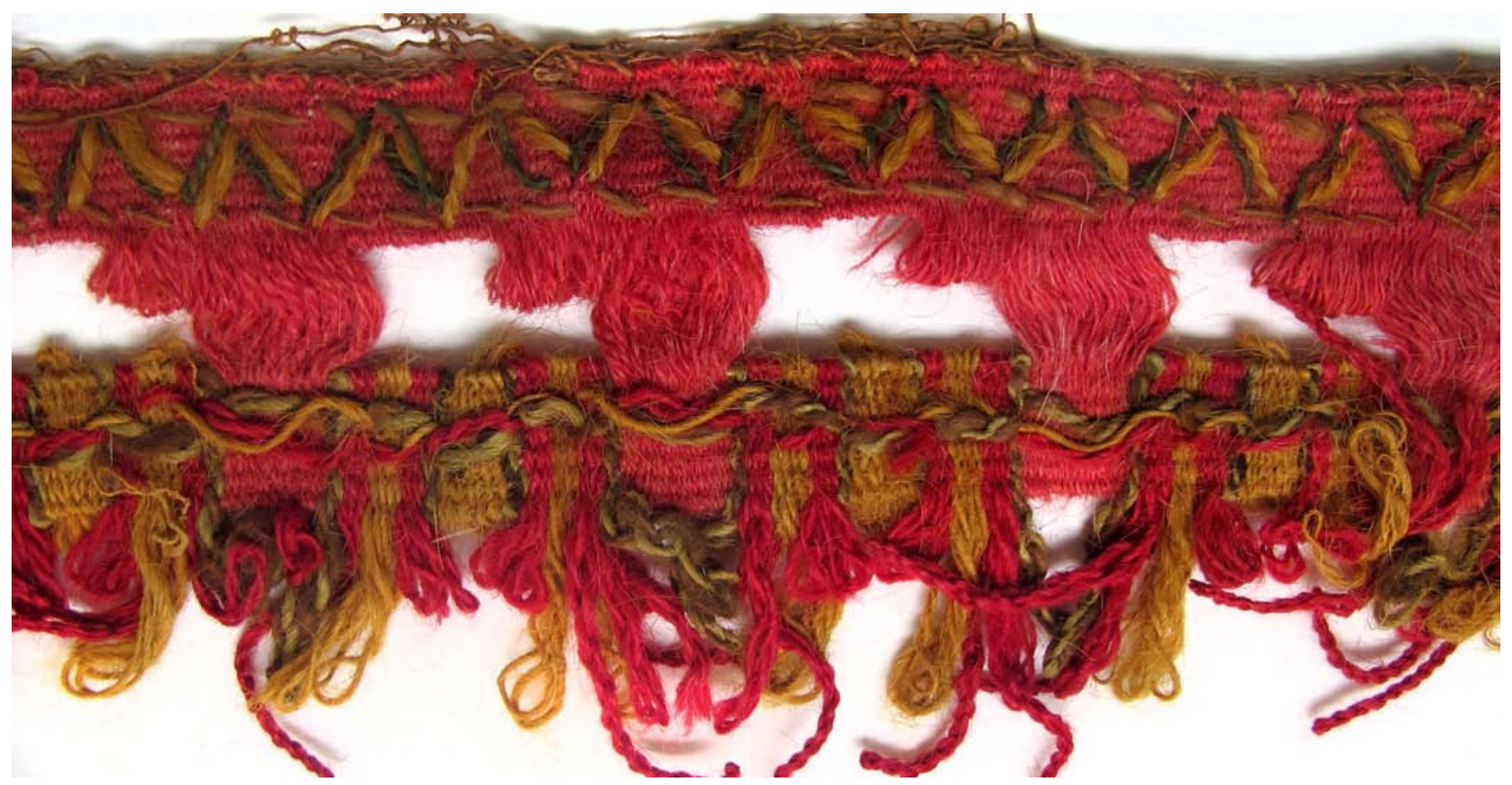

\section{Museum number: V 9.176}

Item: Fringe band from tunic

Style: North Coast, Chimu

Size: $180 \times 5 \mathrm{~cm}$

Material/technique: The textile has cotton $2 \mathrm{Z}$ warp and $2 \mathrm{~S}$ camelid fiber wefts. The tapestry band has openwork and at bottom 1,5 cm weft fringe. At top is a zigzag embroidery (yellow/green on one side, red on other). At top fragments of a plain weave, loose cotton textile (warp and weft S). 


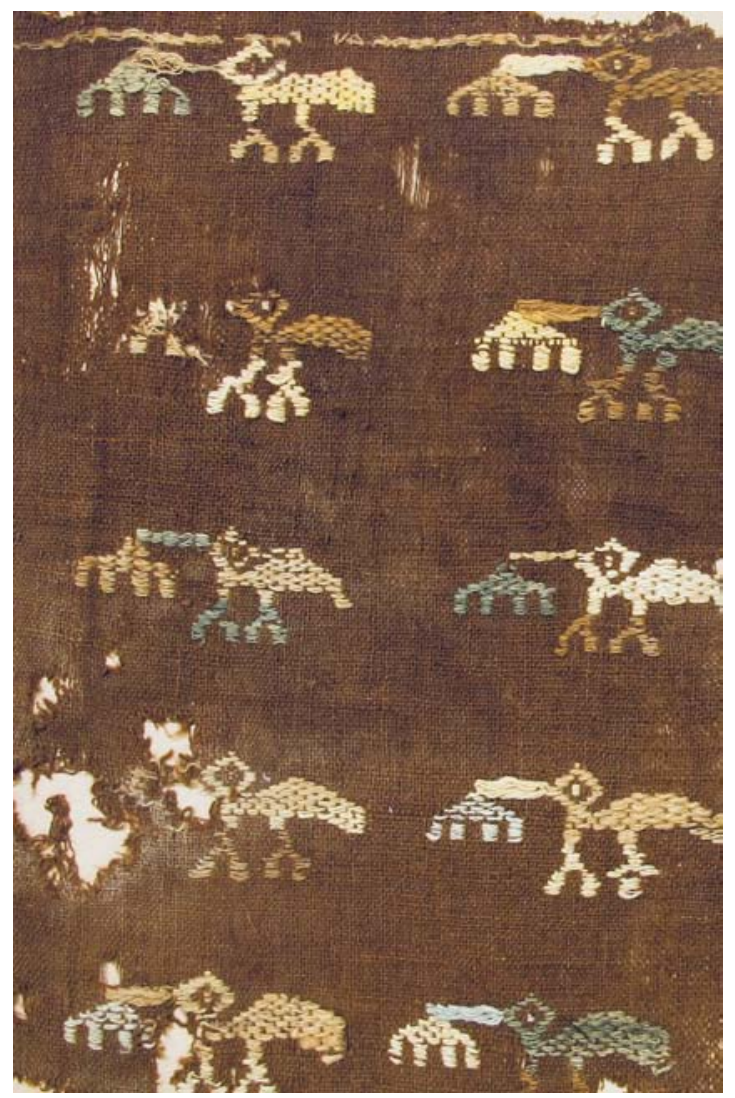

\section{Museum number: V 9.184}

Item: Fragment

Style: North coast

Size: $30 \times 25 \mathrm{~cm}$

Material/technique: The textile is in plain weave cotton with warp and weft $\mathrm{S}$. The threadcount is $14 \times 11 \mathrm{~cm}$.

The pattern is brocated birds in paired cotton, $\mathrm{S}$ and $\mathrm{Z}$ varying.

The fragment has one side selvedge

\section{Museum number: V 9.192}

Item: Loincloth for children?

Style: North coast

Size: $38 \times 15 \mathrm{~cm}$

Material/technique: the textile is woven in cotton with warp $2 S$ and $2 Z$ and weft paired $Z$. It is plain weave with paired wefts and single warp. It has 4 selvedges. The threadcount is $9 \times 9$ per $\mathrm{cm}$.

\section{Museum number: V 9.194}

Item: Textile

Style: North coast

Size: $28 \times 22 \mathrm{~cm}$

Material/ technique: A complete textile with 4 selvedges in cotton S, gauze weave and plain weave. The threadcount is $11 \times 11$ per $\mathrm{cm}$.
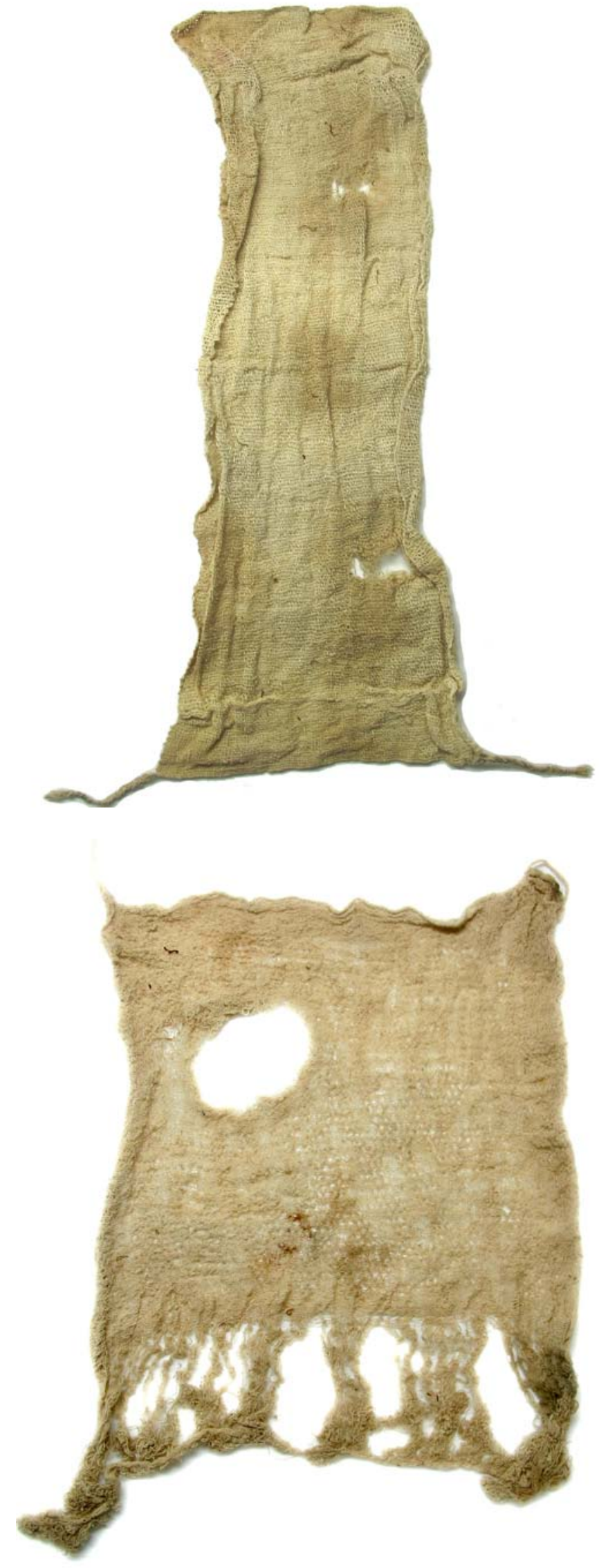


\section{Museum number: V 9.213}

Item: Fragment

Culture: North Coast

Size: $38 \times 22 \mathrm{~cm}$

Material/technique: The textile is in cotton S woven in discontinous warp and weft. The threadcount is 28-32 $\times 12$ per $\mathrm{cm}$.

The squares have after the "weaving" been taken apart, dyed individually and sewn back together. Each square is between $1,2 \times 1,2$ and 1,5 $x 1,5 \mathrm{~cm}$.
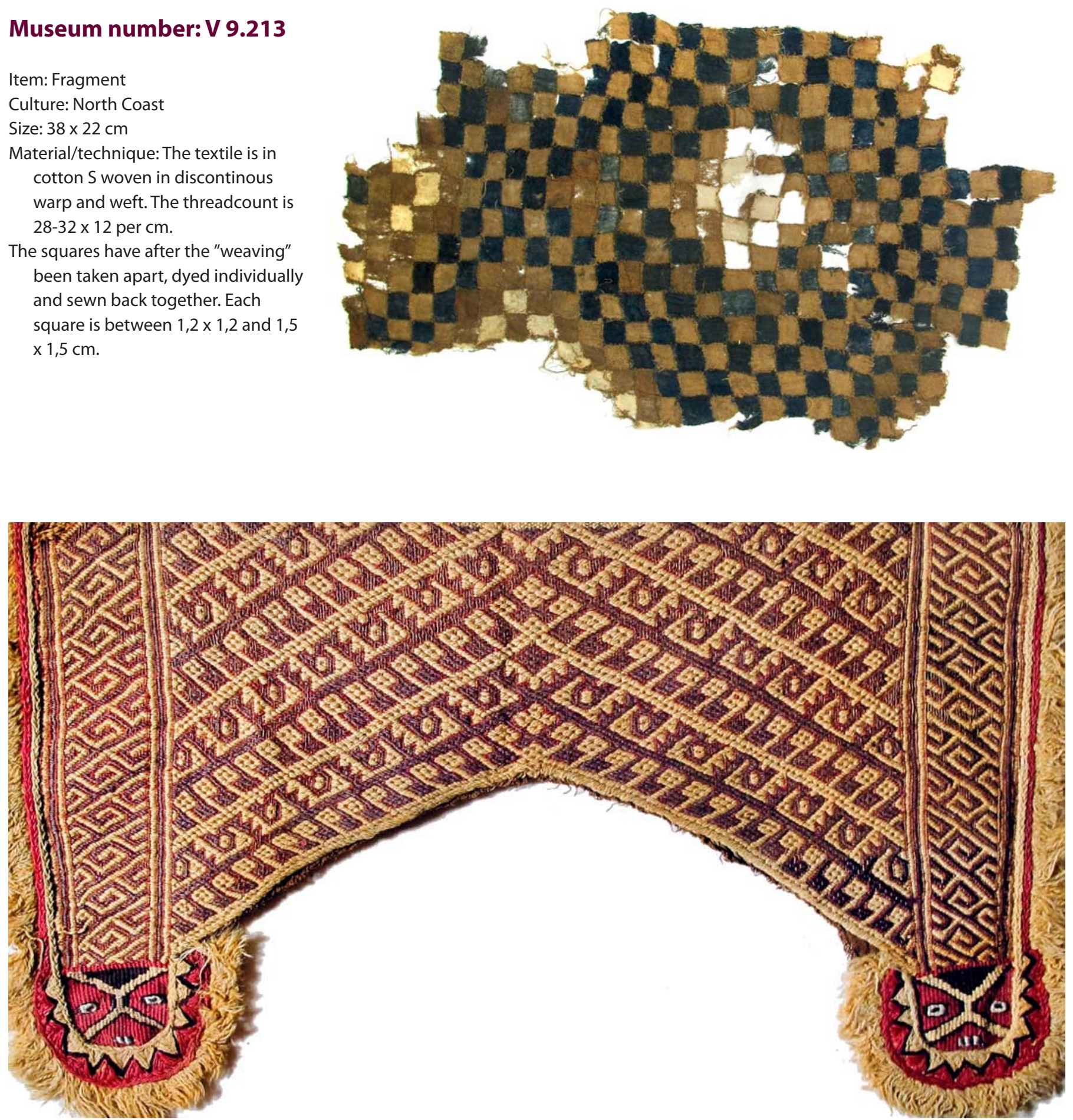

\section{Museum number: V 9.222}

\section{Item: Fragment}

Style: North Coast, Chimu

Size: $20 \times 34 \mathrm{~cm}$

Material/technique: A plain weave cotton textile (warp S and weft $2 \mathrm{~S}$ ) with camelid fiber $2 \mathrm{~S}$ pattering in complementary weft weave (lancée). It has tapestry woven figures (heads) at bottom with a fringe in $2 \mathrm{~S}$ camelid fiber. These tapestry heads are woven separately and stitched on. The threadcount is $17 \times 30$ per $\mathrm{cm}$. The textile was sewn to a cotton fabric.

Bibliography: Reiss \& Stübel, pl.61-62a.

D’Harcourt pl. 85 


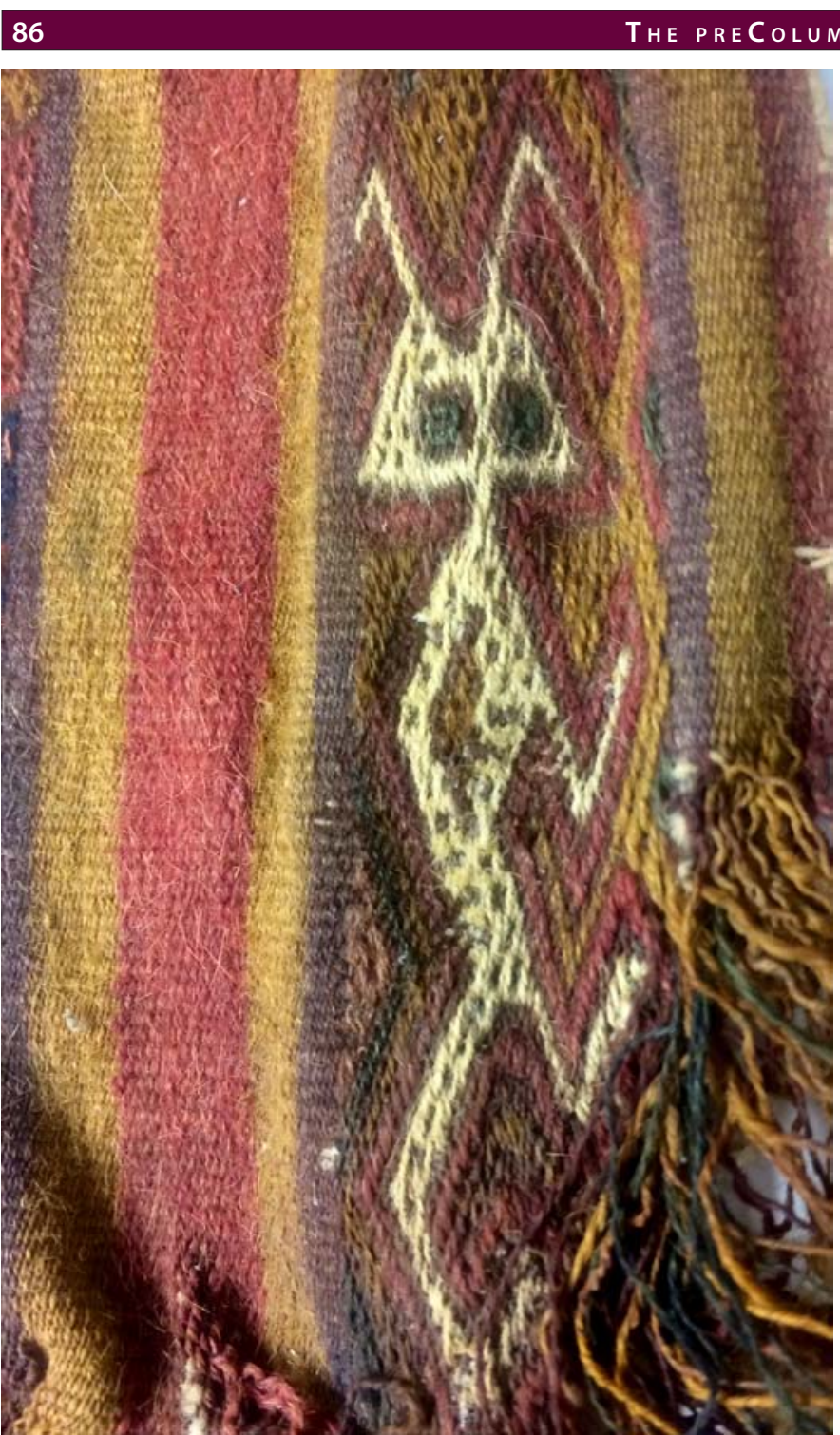

\section{Museum number: V 9.281}

Item: Fragment

Style: North coast

Size: 12,5 (+30 cm unwoven warp) x $30 \mathrm{~cm}$

Material/technique: The textile is in complimentary weft weave and weft rep. The warp is cotton $3 Z$ and the weft is camelid fiber $2 \mathrm{~S}$. The textile has one weft-selvedge and one warp-selvedge. The fragment has $30 \mathrm{~cm}$ unwoven warp - is probably unfinished.

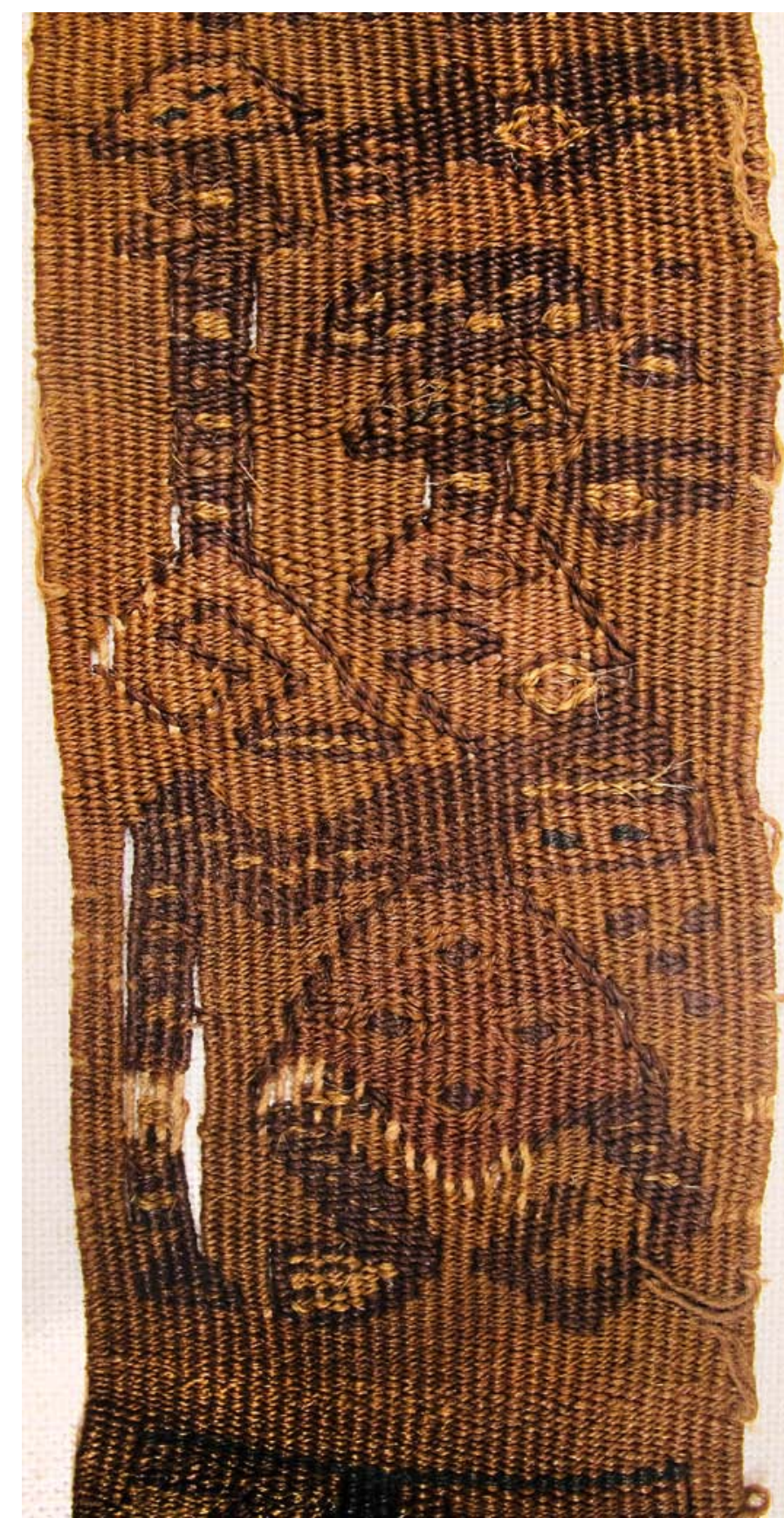

\section{Museum number: V 9.289}

Item: Fragment of band

Style: North Coast, Chimu

Size: $50 \times 4 \mathrm{~cm}$

Material/technique: A tapestry band with one warp-selvedge and two weft-selvedges.

The warp is cotton $3 Z$ and the weft is camelid fiber $2 S$. The threadcount is $11 \times 60$ per $\mathrm{cm}$. 


\section{Museum number: V 9.316}

Item: Complete Textile

Style: North coast

Size: $33 \times 18 \mathrm{~cm}$

Material/technique: The textile has supplementary warp and weft patterning (or incomplete double weave). With floating warps and wefts at back. White warp and weft are cotton $2 \mathrm{~S}$, the brown warp and weft are cotton $Z$.

The textile has 4 selvedges.

Bibliography: Ann Rowe 1977 (Warp patterned weaves of the Andes) p. 46-48

\section{Museum number: V 9.321}

Item: Loincloth

\section{Style: North coast}

Size: $57,5 \times 130 \mathrm{~cm}$. Belt $103 \times 7 \mathrm{~cm}$

Material/technique: The loincloth is woven in cotton $\mathrm{S}$, plain weave with paired warp and single weft. The threadcount is 6 (paired) $x 6$ per $\mathrm{cm}$.

At the end of the belt and of the loincloth is an attached tapestry band - 4 $\mathrm{cm}$ wide. The warp (lengthwise) is cotton $2 \mathrm{~S}$ and the weft is $2 \mathrm{~S}$ camelid fiber.

Added to this band is a small fringe-band $2,5 \mathrm{~cm}$ wide ( $1 \mathrm{~cm}$ woven, 1,5 $\mathrm{cm}$ looped fringe). It is in cotton $\mathrm{Z}$ with paired wefts and single warps.
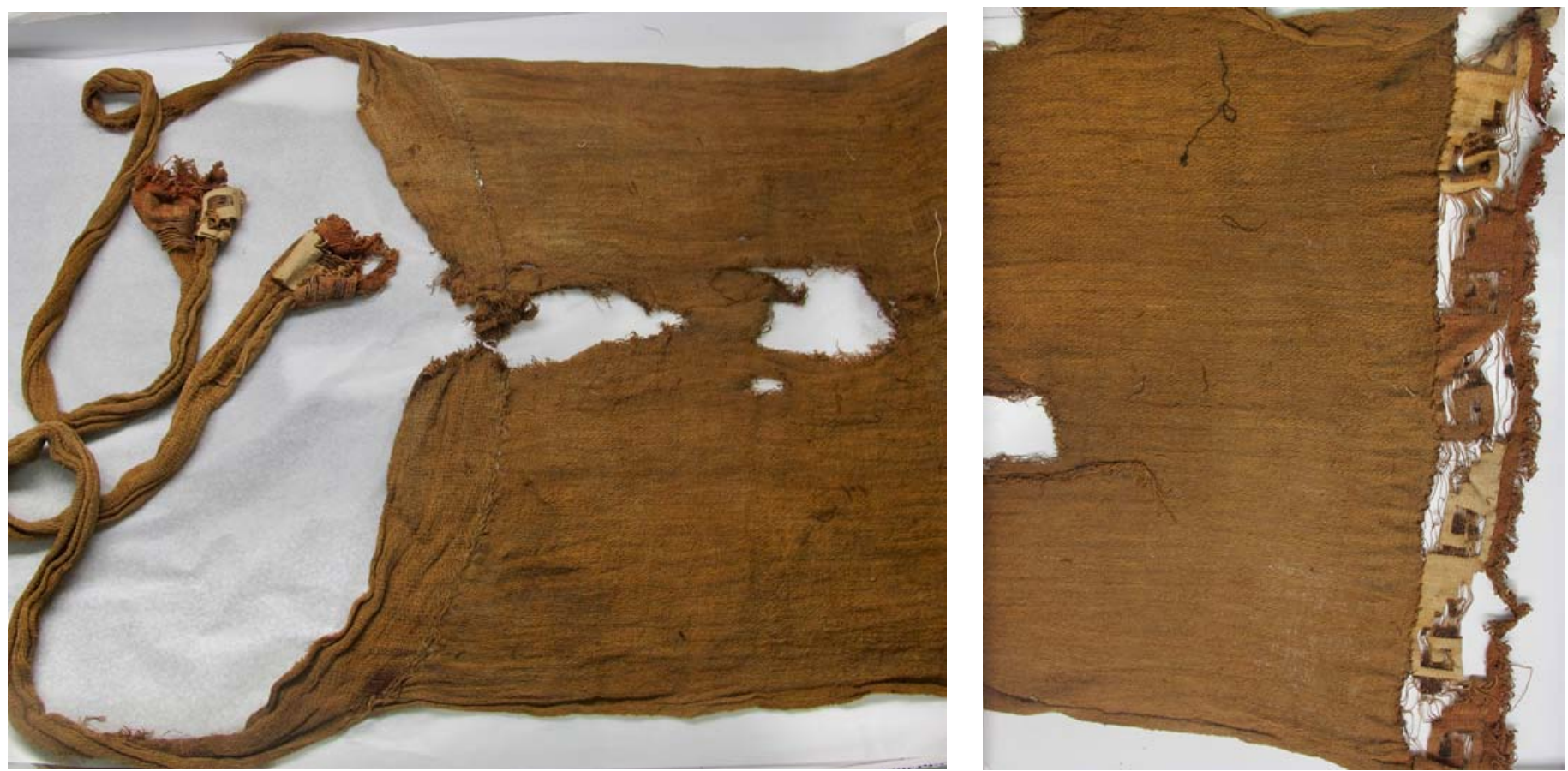


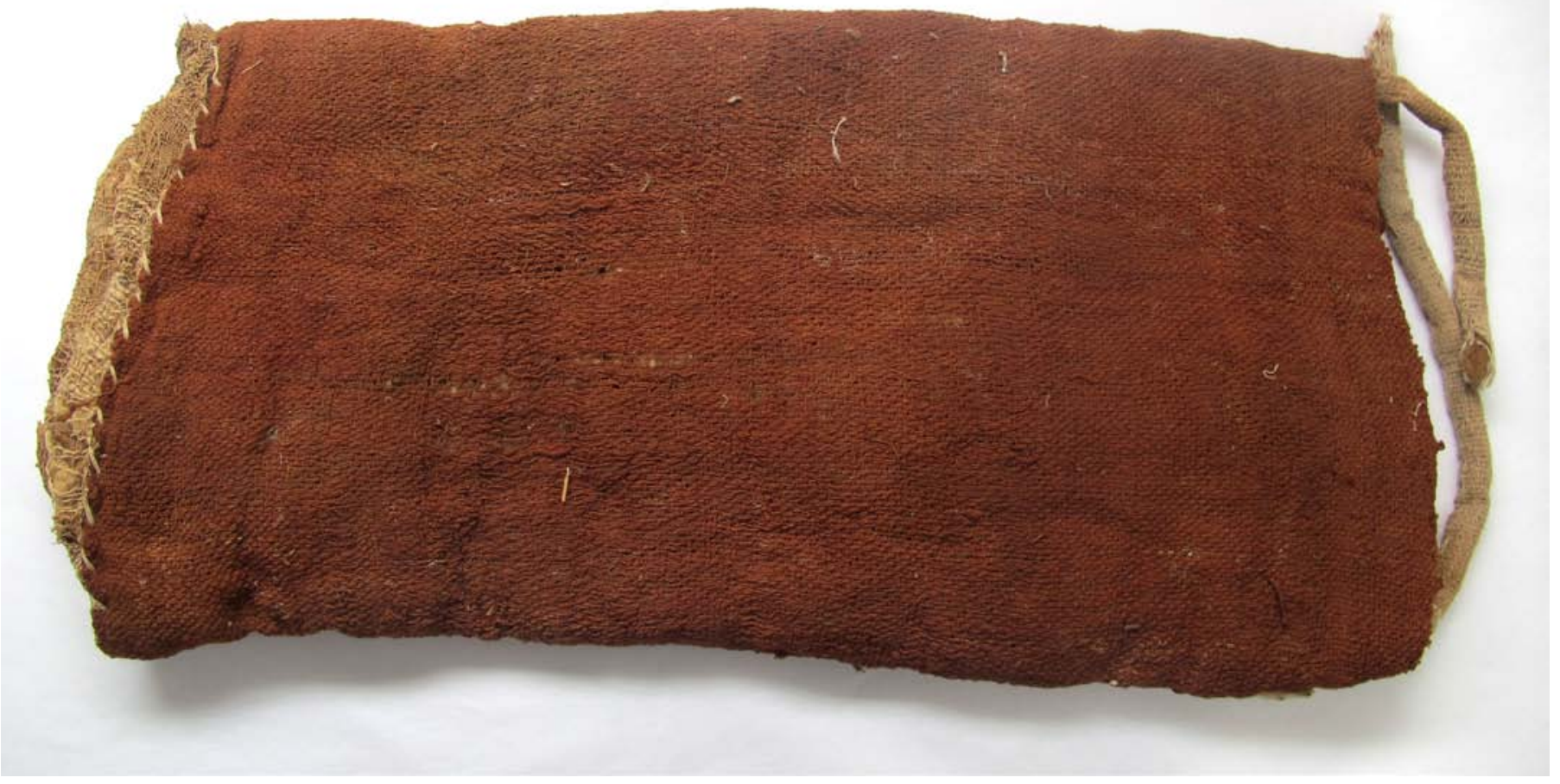

\section{Museum number: V 9.352}

Item: Head ornament

Style: North coast

Size: $45 \times 22 \mathrm{~cm}$. Bands: $1 \times 25$ and $1 \times 14 \mathrm{~cm}$

Material/technique: The outer layer is in cotton $2 \mathrm{~S}$ woven in plain weave with paired warps. The threadcount is 7 paired warps (lengthwise) $x 6$ single wefts per $\mathrm{cm}$. The textile has selvedges at 3 sides (bottom, and two sides). The top part is cut off the textile.

Inside this is a textile in cotton S (slightly overspun), woven in plain weave. The threadcount is about $5 \times 5$ per $\mathrm{cm}$.

The straps are cotton $Z$ woven in plain weave. The threadcount is 13 warps $x 6$ wefts per $\mathrm{cm}$.

Bibliography: Heiko Prümers, 1983, p. 92 (unpublished thesis)

Ann Rowe 1984 -110-133, fig. 70,75,88,89,126,127

Ann Rowe 1980 p. 105-6, fig 32-34,44

\section{Museum number: V 10.188}

Item: Fragment

Style: North coast

Size: $51 \times 27 \mathrm{~cm}$

Acquired: 1992

Material/technique: The textile is in plain weave cotton. It is woven in plain weave cotton with a warp in paired $S$ and a weft in single $S$. The threadcount is 14 (paired) $\times 9$ per $\mathrm{cm}$. There are no selvedges.

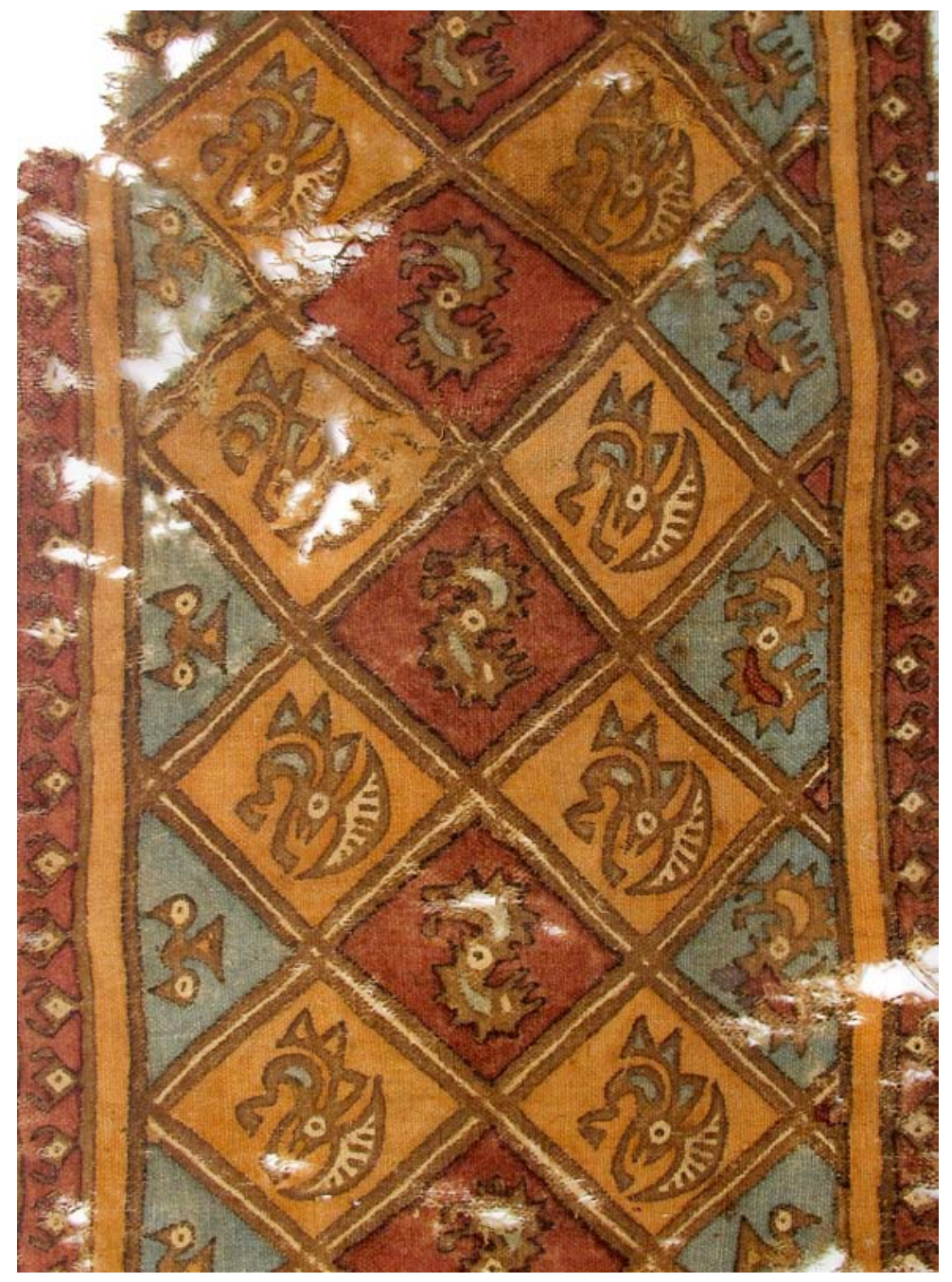




\section{Museum number: V 9.138}

Item: Complete Scarf

Style: South coast

Size: $58 \times 64 \mathrm{~cm}$

Material/technique: The scarf consists of two panels sewn together. It is woven in dovetailed tapestry, sometimes with eccessive wefts. The warp is $2 \mathrm{~S}$ cotton and the weft $2 \mathrm{~S}$ cotton and camelid fiber. The threadcount is $8 \times 24-28$ per $\mathrm{cm}$.
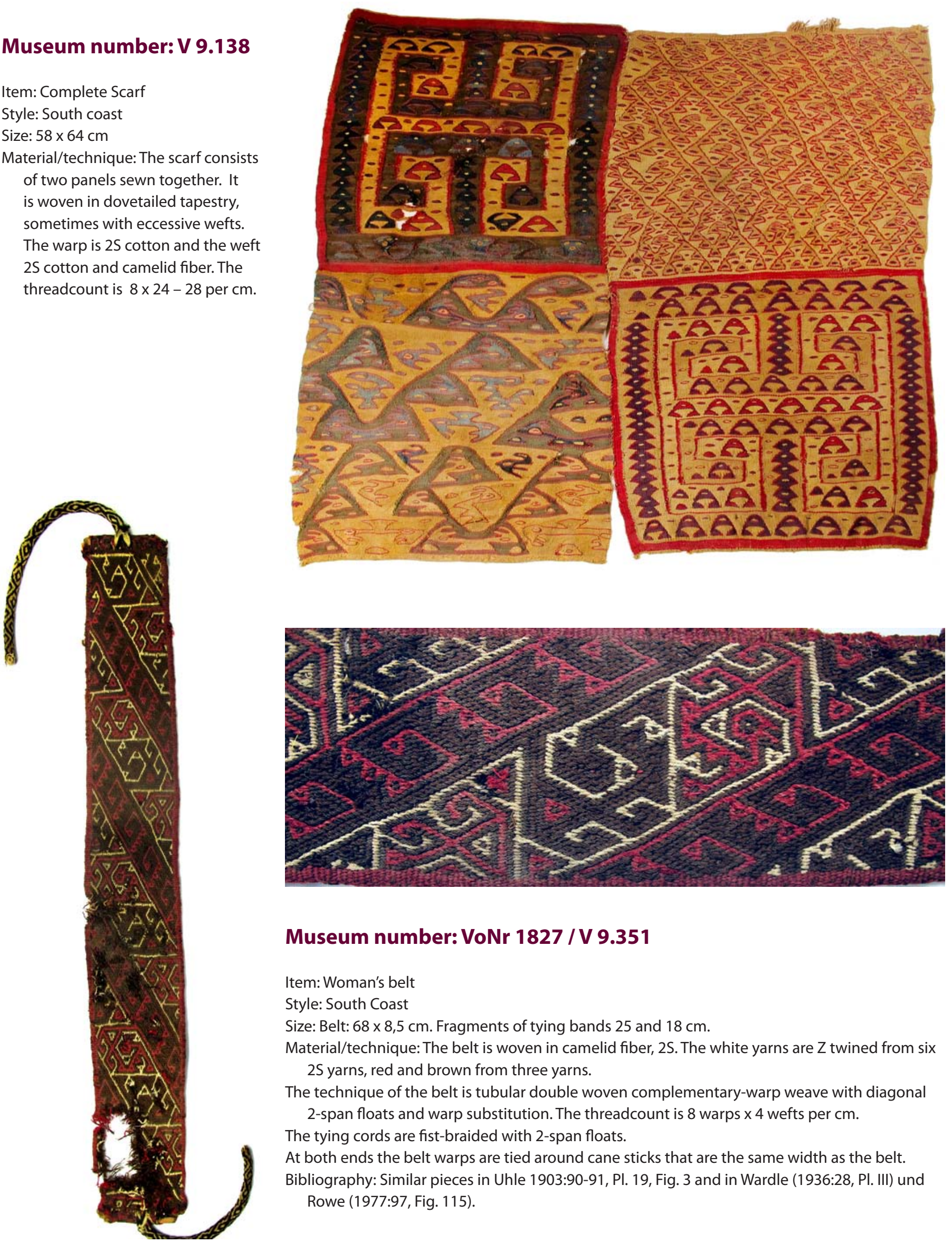

\section{Museum number: VoNr 1827 / V 9.351}

Item: Woman's belt

Style: South Coast

Size: Belt: $68 \times 8,5 \mathrm{~cm}$. Fragments of tying bands 25 and $18 \mathrm{~cm}$.

Material/technique: The belt is woven in camelid fiber, $2 \mathrm{~S}$. The white yarns are $Z$ twined from six $2 S$ yarns, red and brown from three yarns.

The technique of the belt is tubular double woven complementary-warp weave with diagonal 2 -span floats and warp substitution. The threadcount is 8 warps $x 4$ wefts per $\mathrm{cm}$.

The tying cords are fist-braided with 2-span floats.

At both ends the belt warps are tied around cane sticks that are the same width as the belt. Bibliography: Similar pieces in Uhle 1903:90-91, Pl. 19, Fig. 3 and in Wardle (1936:28, PI. III) und Rowe (1977:97, Fig. 115). 


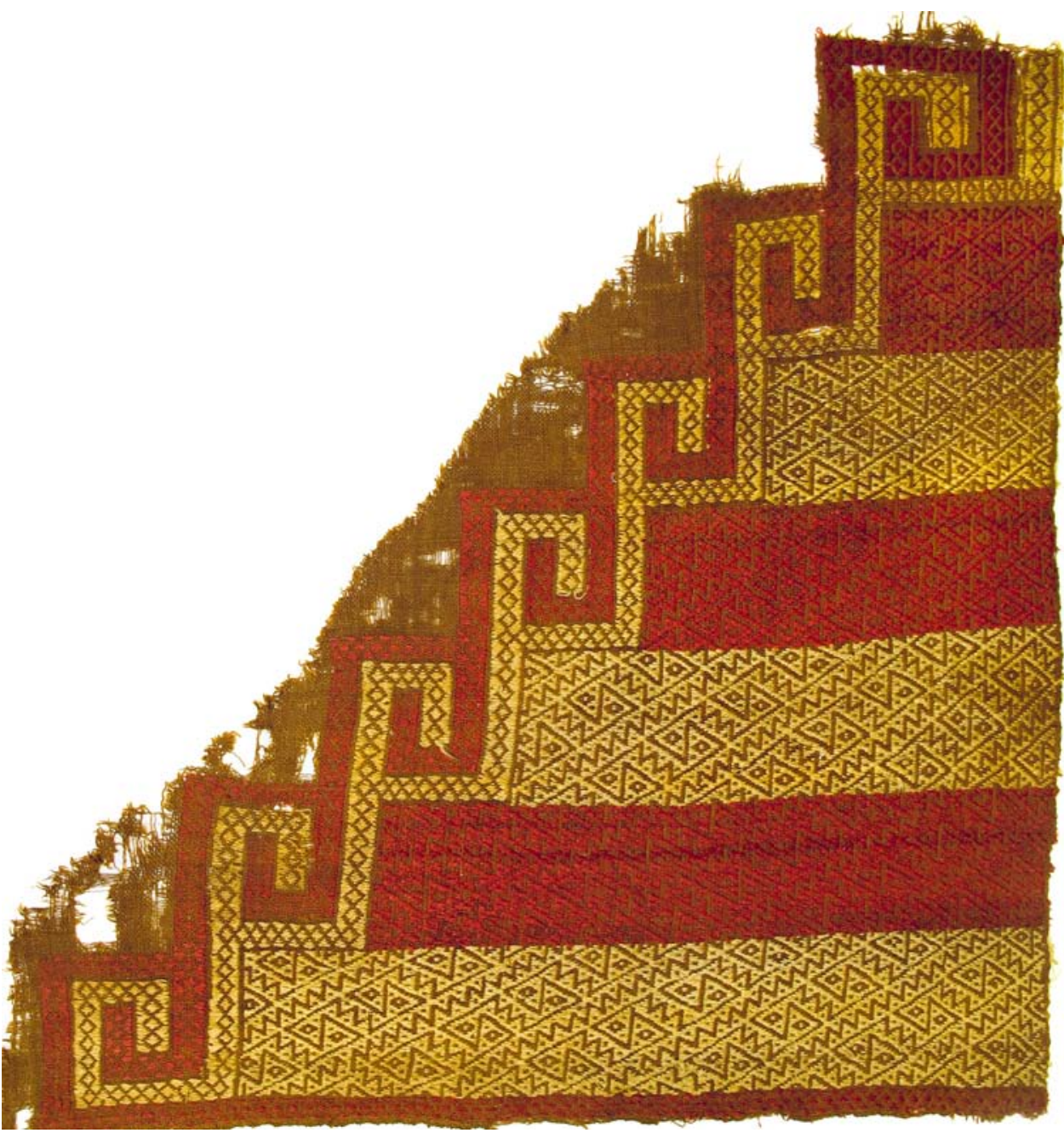

Museum number: V 9.127

Item: Fragment - probably from a mantle.

Style: South Coast

Size: 45 x $45 \mathrm{~cm}$

Material/technique: The textile is a corner from a mantle. It has one warp and one weft selvedge.

The base material is cotton $2 \mathrm{~S}$. The threadcount is $10 \times 10$ per $\mathrm{cm}$.

The patterning is camelid fiber $2 \mathrm{~S}$, lancée brocade (supplementary weft weave).
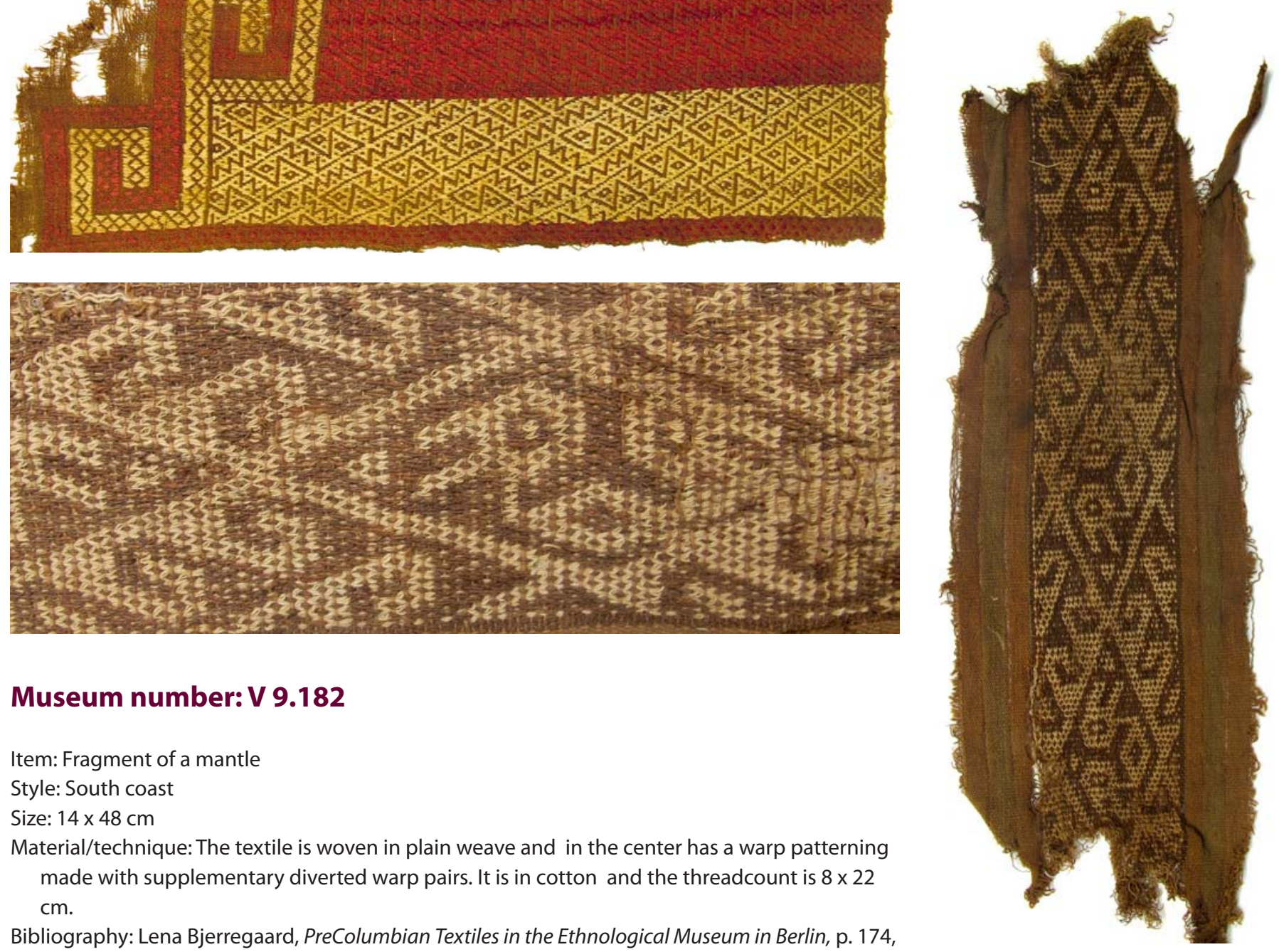

Item: Fragment of a mantle

Style: South coast

Size: $14 \times 48 \mathrm{~cm}$

Material/technique: The textile is woven in plain weave and in the center has a warp patterning made with supplementary diverted warp pairs. It is in cotton and the threadcount is $8 \times 22$ $\mathrm{cm}$.

Bibliography: Lena Bjerregaard, PreColumbian Textiles in the Ethnological Museum in Berlin, p. 174, 2017 , http://digitalcommons.unl.edu/zeabook 52/ 


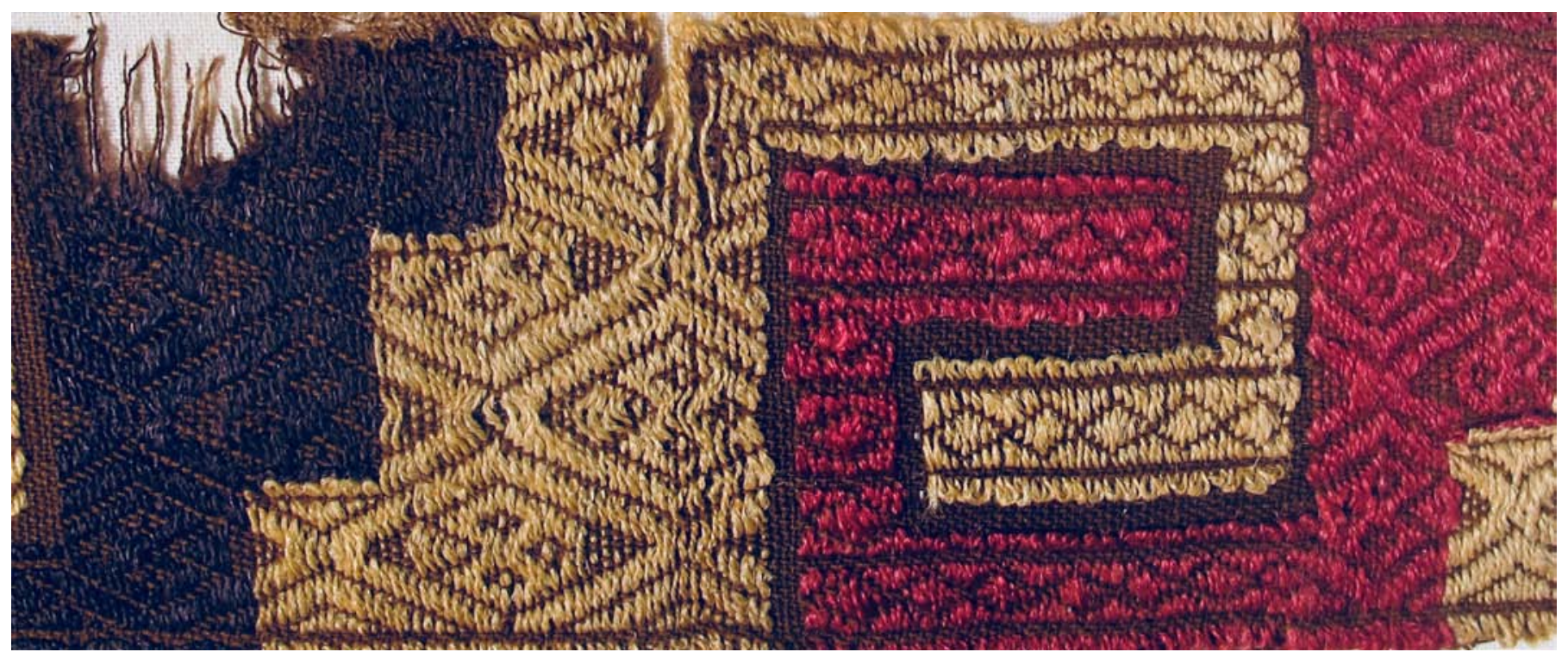

\section{Museum number: V 9.223}

Item: Fragment

Style: South coast

Size: $48 \times 6 \mathrm{~cm}$

Material/technique: Cotton cloth with camelid fiber $2 \mathrm{~S}$ weft brocade. One long-side is a warp-selvedge. There are no other selvedges. The threadcount is $20 \times 12 \mathrm{per} \mathrm{cm}$.

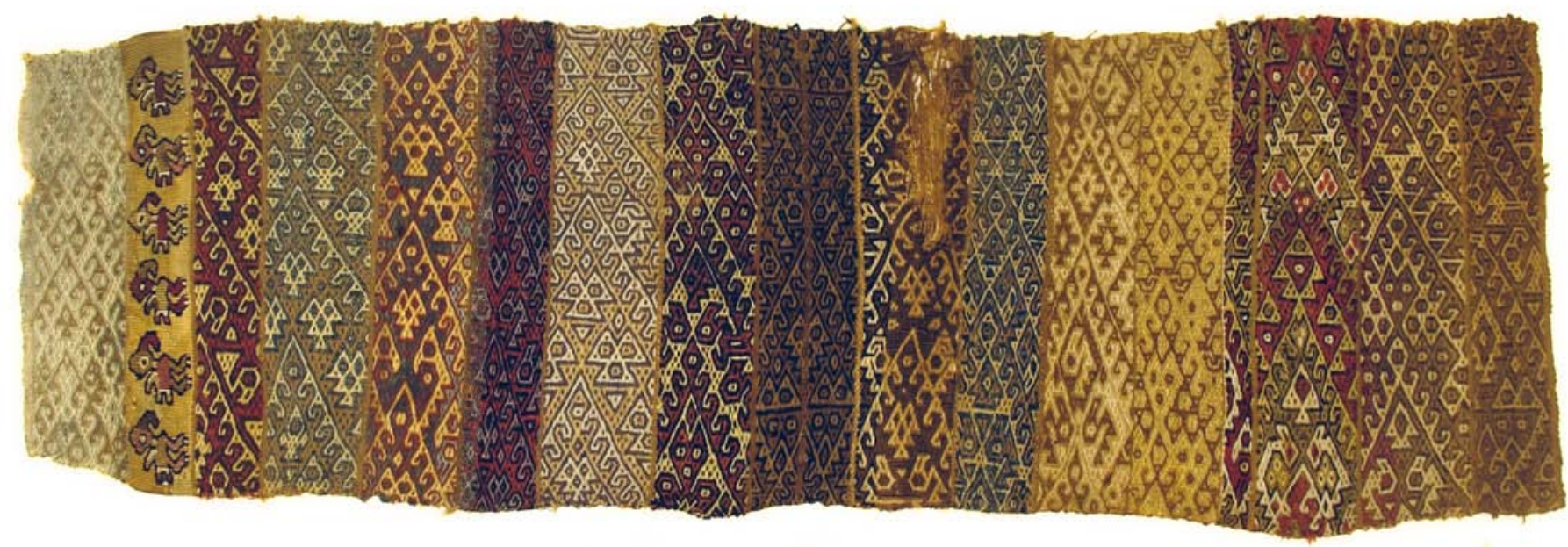

\section{Museum number: V 9.225}

Item: Complete textile

Style: South coast

Size: $50 \times 17 \mathrm{~cm}$

Material/technique: The textile has warp-selvedge at bottom and two side-selvedges. The upper edge has cut warps that have been doubled and sewn into the upper $0,3 \mathrm{~mm}$ wefts.

The base material is cotton $2 \mathrm{~S}$ in both warp and weft. The patterns are in camelid fiber 2S, woven in supplimentary weft (lancée). One pattern (2. From top) is tapestry (slit and eccentric). 

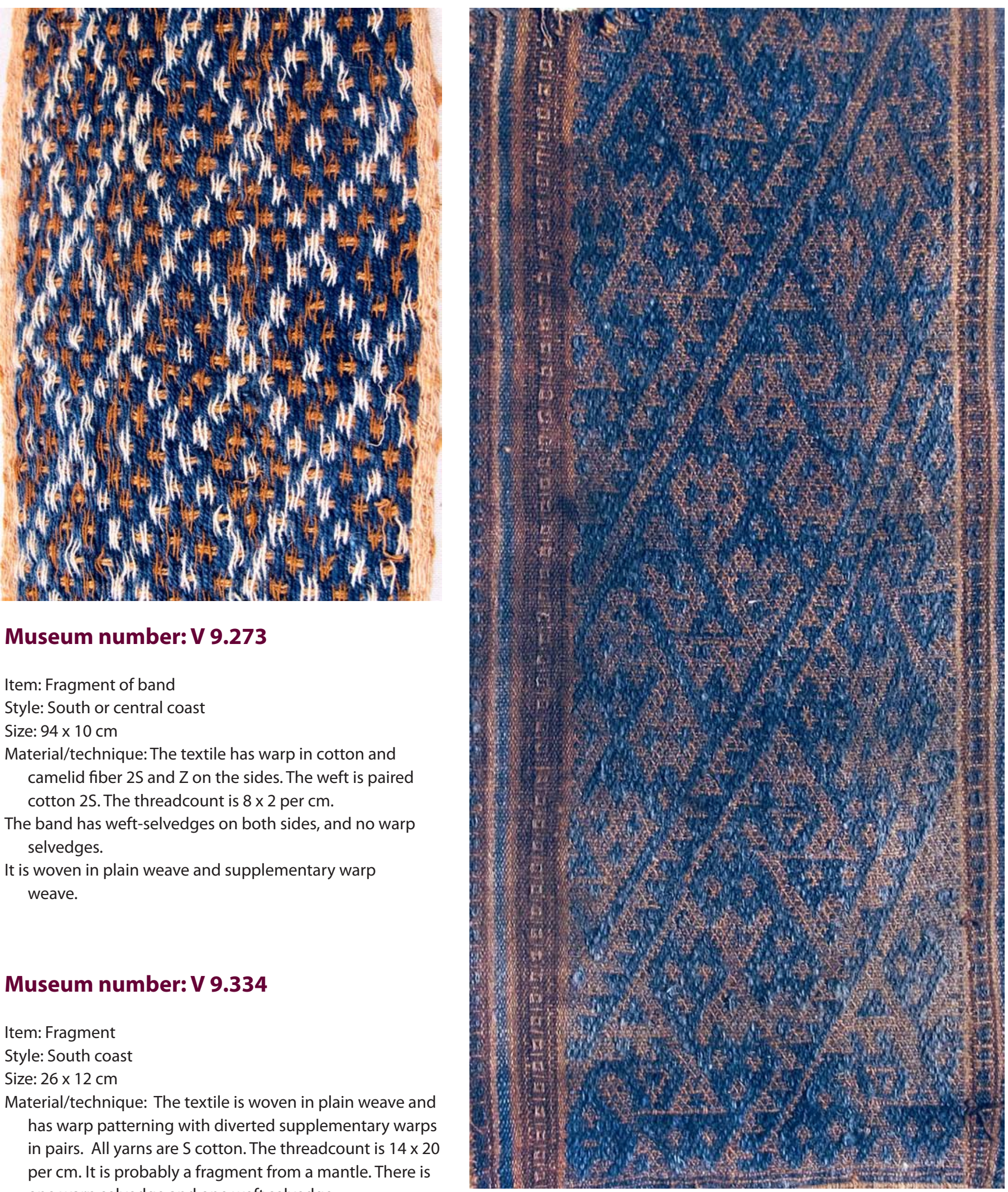

\section{Museum number: V $\mathbf{9 . 2 7 3}$}

Item: Fragment of band

Style: South or central coast

Size: $94 \times 10 \mathrm{~cm}$

Material/technique: The textile has warp in cotton and camelid fiber $2 \mathrm{~S}$ and $\mathrm{Z}$ on the sides. The weft is paired cotton $2 \mathrm{~S}$. The threadcount is $8 \times 2$ per $\mathrm{cm}$.

The band has weft-selvedges on both sides, and no warp selvedges.

It is woven in plain weave and supplementary warp weave.

\section{Museum number: V 9.334}

\section{Item: Fragment}

Style: South coast

Size: $26 \times 12 \mathrm{~cm}$

Material/technique: The textile is woven in plain weave and has warp patterning with diverted supplementary warps in pairs. All yarns are S cotton. The threadcount is $14 \times 20$ per $\mathrm{cm}$. It is probably a fragment from a mantle. There is one warp selvedge and one weft selvedge.

This textile is very similar to V 9.335 - but the pattern is slightly different and the threadcount also.

Bibliography: Lena Bjerregaard, PreColumbian Textiles in the Ethnological Museum in Berlin, p. 174, 2017, http://digitalcommons.unl.edu/zeabook 52/ 


\section{Museum number:} V 9.335

Item: Fragment.

Style: South coast

Size: $30 \times 12 \mathrm{~cm}$

Material/technique: The textile is in cotton $\mathrm{S}$ (both warp and weft). It is woven in plain weave and supplementary warp patterning with diverted warps in pairs. There is one warp selvedge. The threadcount is $11 \times 11$ per $\mathrm{cm}$ (in edge plain weave).

This textile is very similar to V 9.334 - but the pattern is slightly different and the threadcount also.

Bibliography: Lena Bjerregaard,

PreColumbian Textiles in the Ethnological Museum in Berlin, p. 174, 2017, https://digitalcommons. unl.edu/zeabook/52/

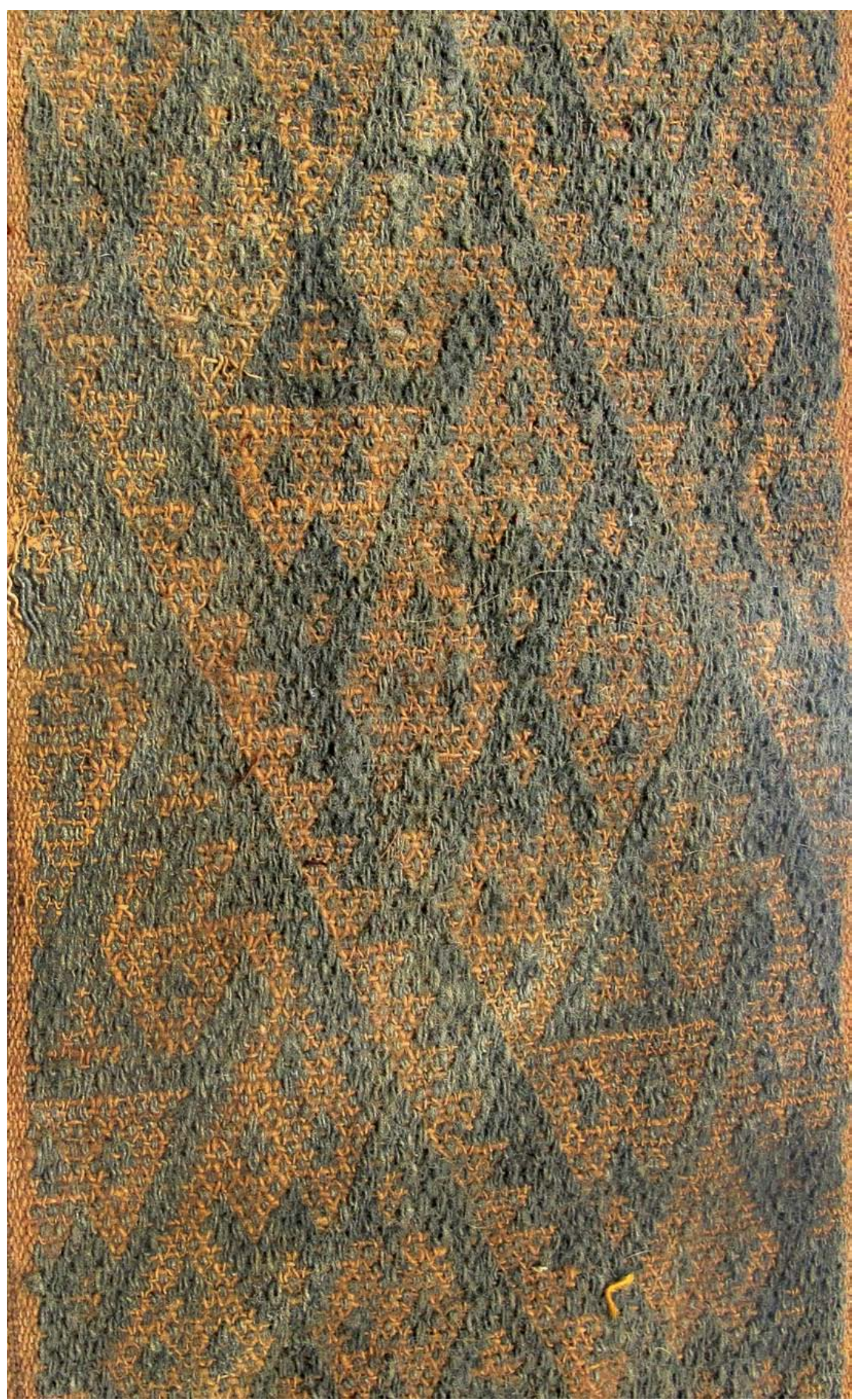




\section{INKA - 1400-1550 AD}

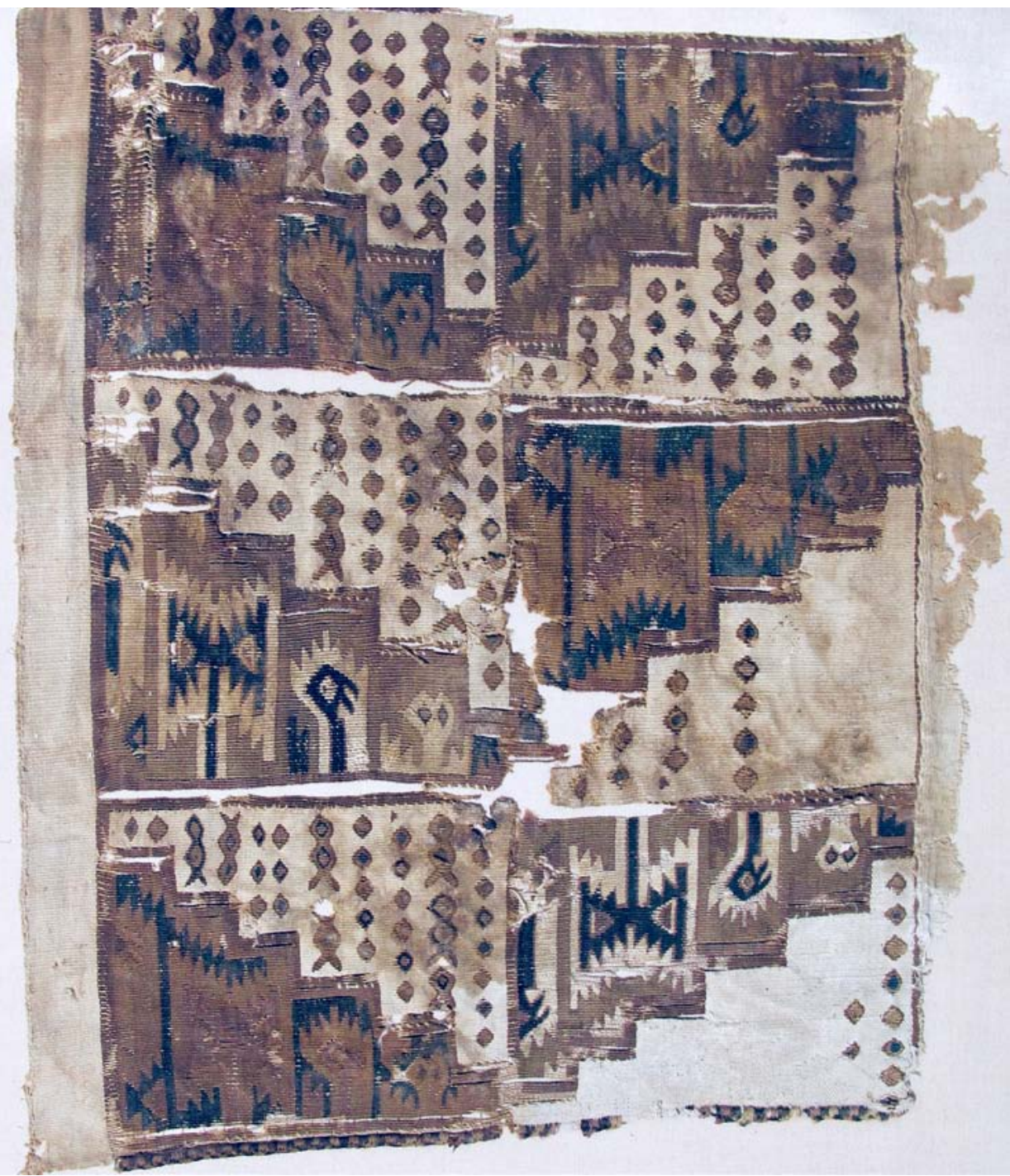

\section{Museum number: V 8.990}

Item: Fragment

Style: Inka

Size: $28 \times 32 \mathrm{~cm}$

Material/technique: A square, complete textile in tapestry. The warp is cotton $3 Z$ (in one third of the textile two colors are twined together (brown + white) - in the rest of the textile the warps are monocolored. The wefts are mainly cotton $Z$ and a few yarns of camelid fiber $2 \mathrm{~S}$. The threadcount is $12 \times 50-60$ per $\mathrm{cm}$.

The tapestry fragment has 4 complete selvedges - over one weft-

selvedge is a cross knit loop stitch embroidery.

Along one warp-end is a fragment of a plain weave cotton $S$ textile. The threadcount of this textile is $28 \mathrm{x}$ 20 per $\mathrm{cm}$.

\section{Museum number: V 9.151}

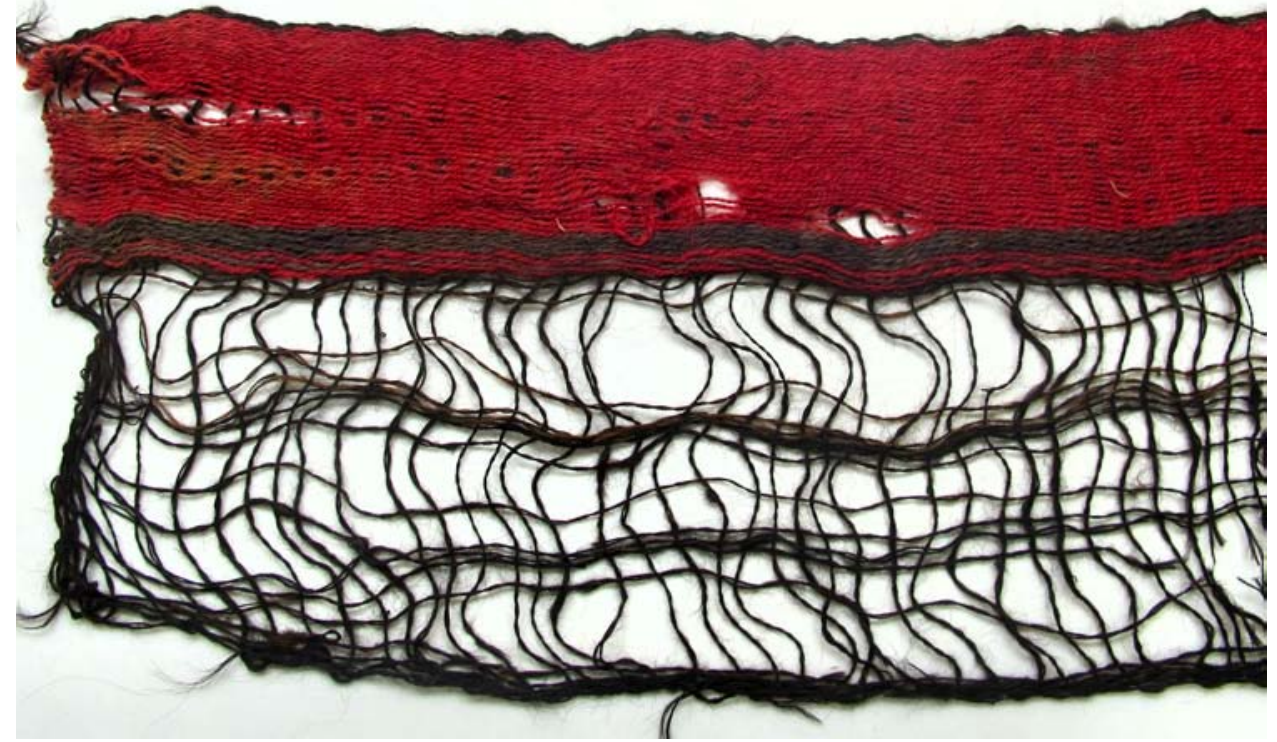

Item: Headband

Style: Inka

Size: $115 \times 17 \mathrm{~cm}$

Material/technique: This headband is complete with warp- and weftselvedges all around. It has $7 \mathrm{~cm}$ red camelid fiber warp rep and 10 $\mathrm{cm}$ coarse brown camelid fibers in plain weave (probably llama). All yarns are $2 \mathrm{~S}$.

See also V 9.136

Bibliography: similar headband Lena Bjerregaard, p.196, PreColumbian Textiles in the Ethnological Museum in Berlin, 2017, https:// digitalcommons.unl.edu/ zeabook/52/ 


\section{Museum number: V 9.136}

Item: Headband (complete)

Style: Inka

Size: $136 \times 18$

Material/ technique: This headband is complete with warp- and weftselvedges all around. It has $7 \mathrm{~cm}$ red camelid fiber warp rep and 10 $\mathrm{cm}$ coarse brown camelid plain weave (probably llama). All yarns are $2 \mathrm{~S}$.

See also V 9.151.

Bibliography: similar headband Lena Bjerregaard, PreColumbian Textiles in the Ethnological Museum in Berlin, p. 196, 2017, https://digitalcommons.unl.edu/ zeabook/52/

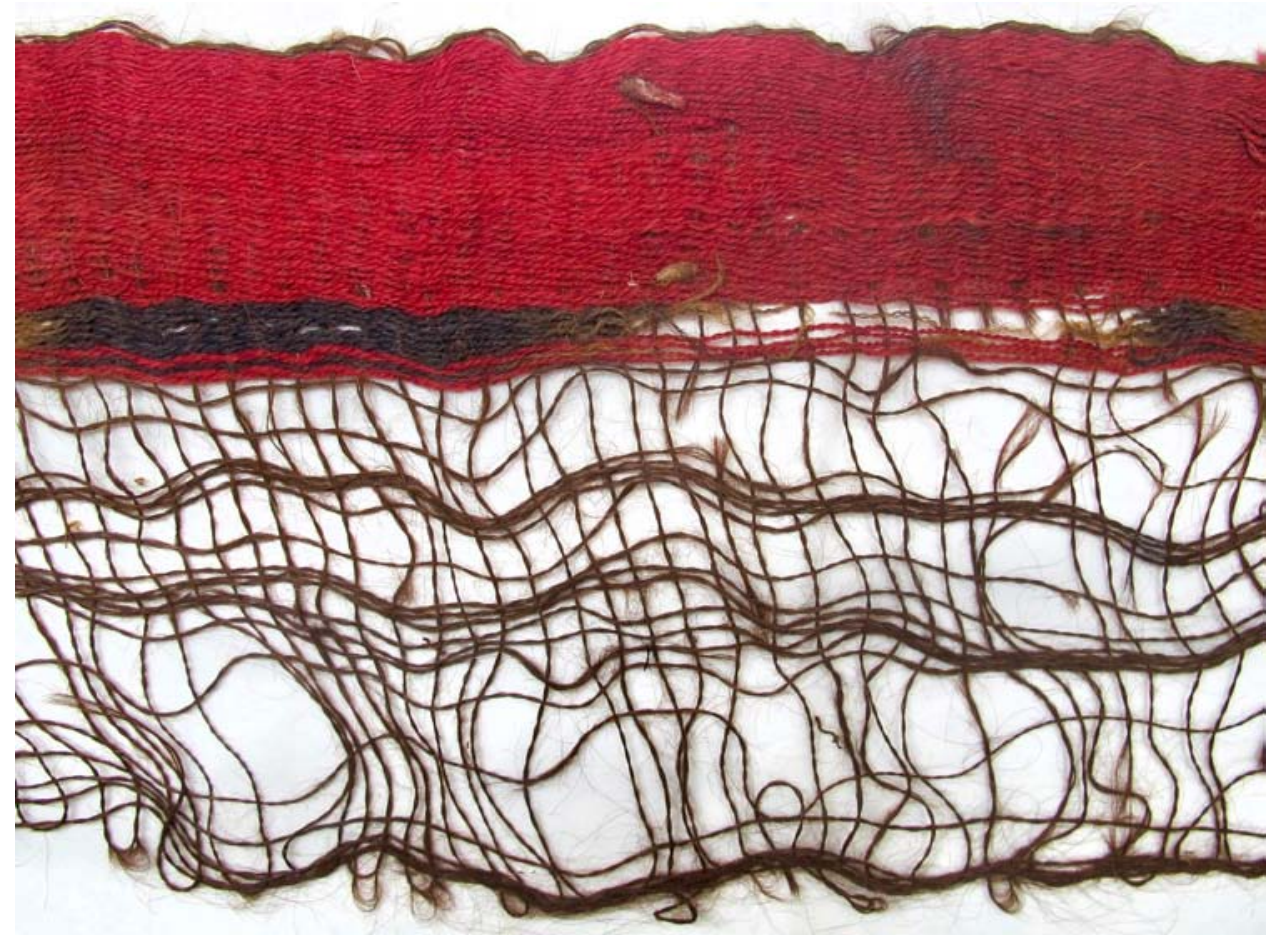

\section{Museum number: V 11.262}

Item: Kipu (complete)

Style: Inka

Size: 52 × $27 \mathrm{~cm}$, (pendant strings on main string)

Material/technique: The kipu is all cotton - all strings are $S$ plied.

Main string is complete and starts with a loop.

Knots: 8 , single, long.

Groups of pendants: 5; 8; 6-6-6; 8,8,8

Strings: main, pendants, secondaries.

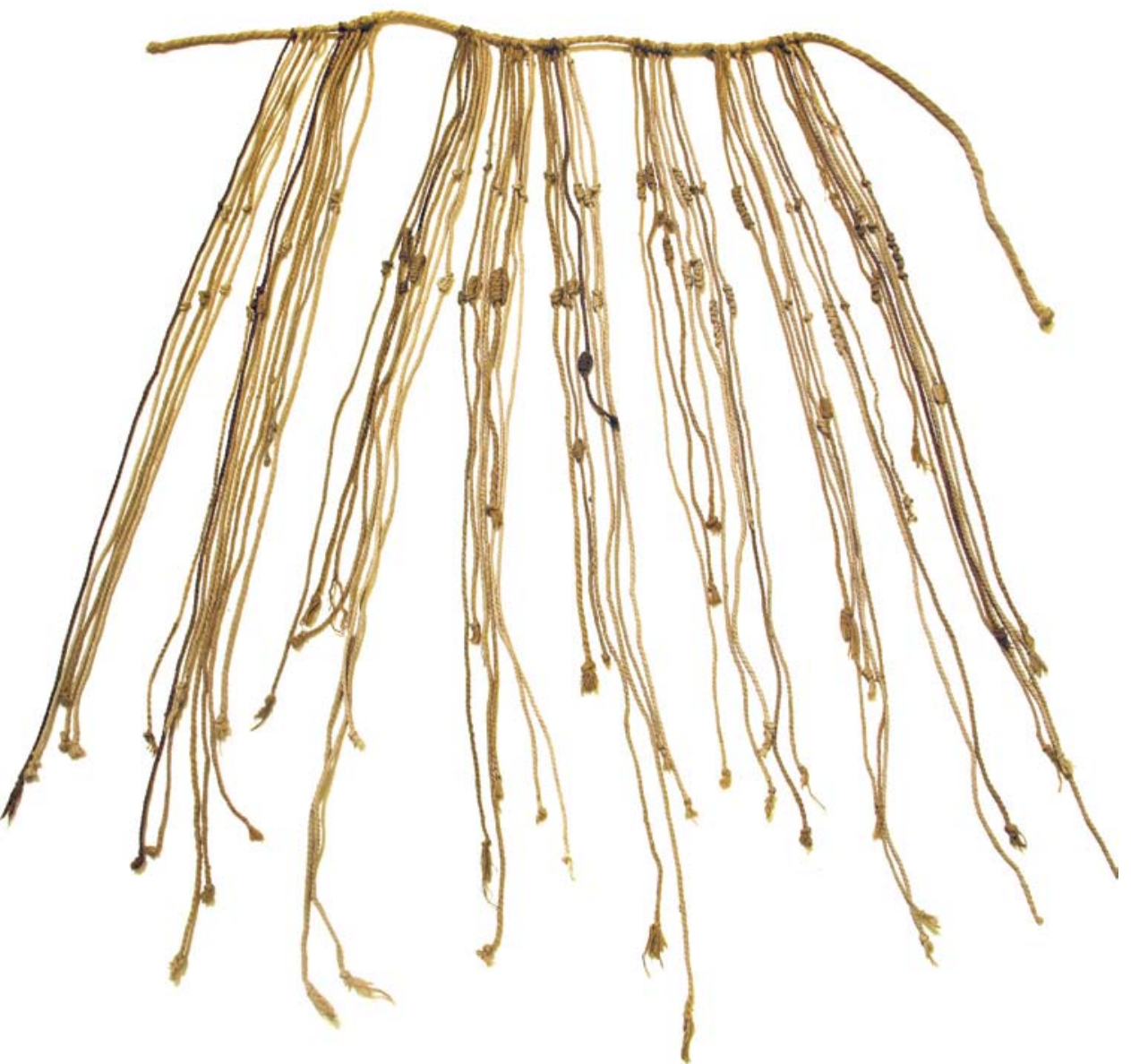




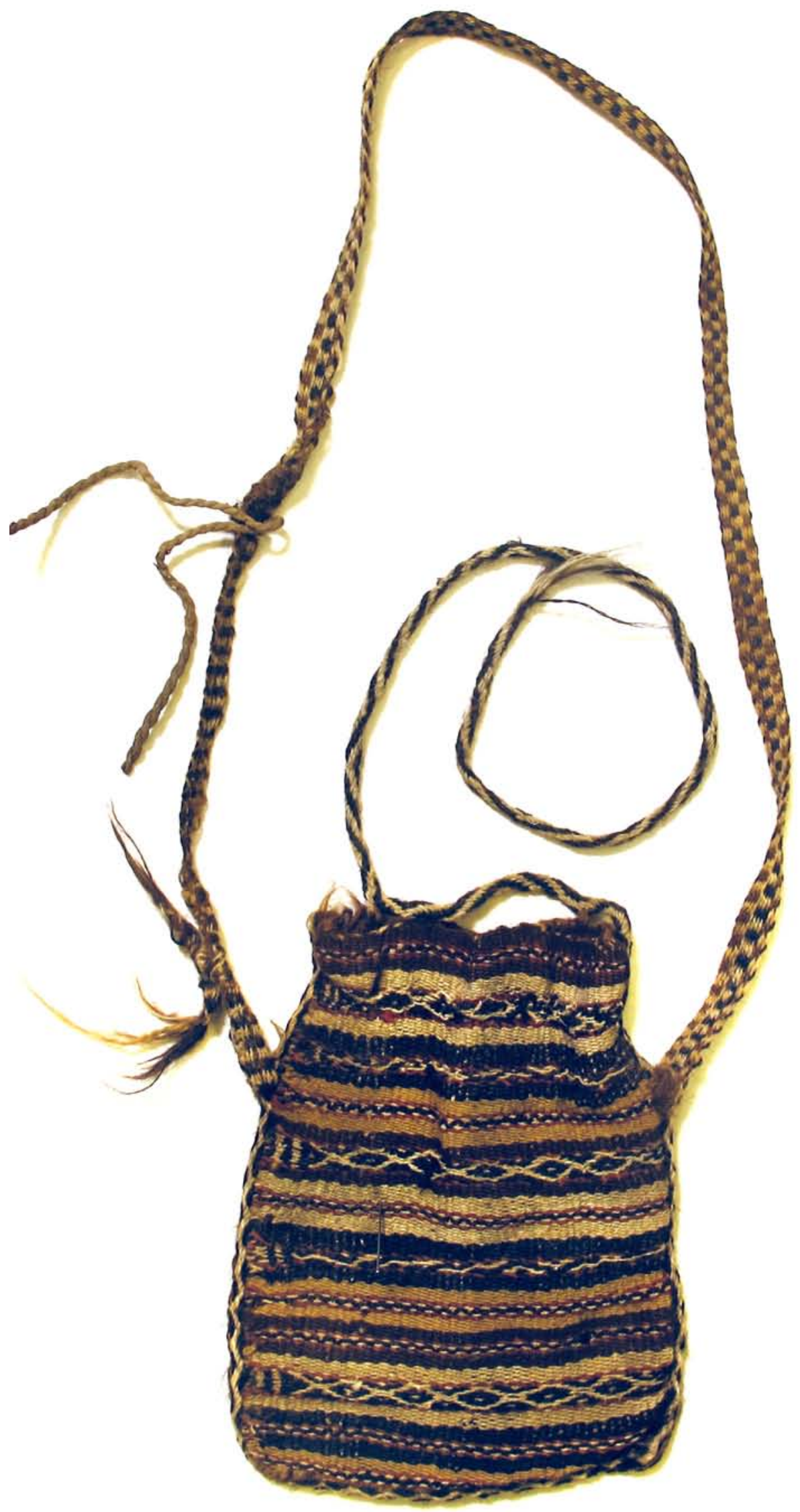

Museum number: V 9.331

Item: Bag

Style: Central coast, Inka

Size: 14 x $18 \mathrm{~cm}$

Material/technique: All yarns are $2 S$ camelid fiber.

The bag is in warp rep with stripes of complementary warp weave. The side and bottom are sewn together/ adorned with stem stitch embroidery. The warp is horizontal when worn.

The threadcount is $20 \times 4$ per $\mathrm{cm}$.

The strap is $75 \times 1 \mathrm{~cm}$ - woven in complementary warp patterning.

At top is a round fistbraided cord attached in 2 places of the top edge. 


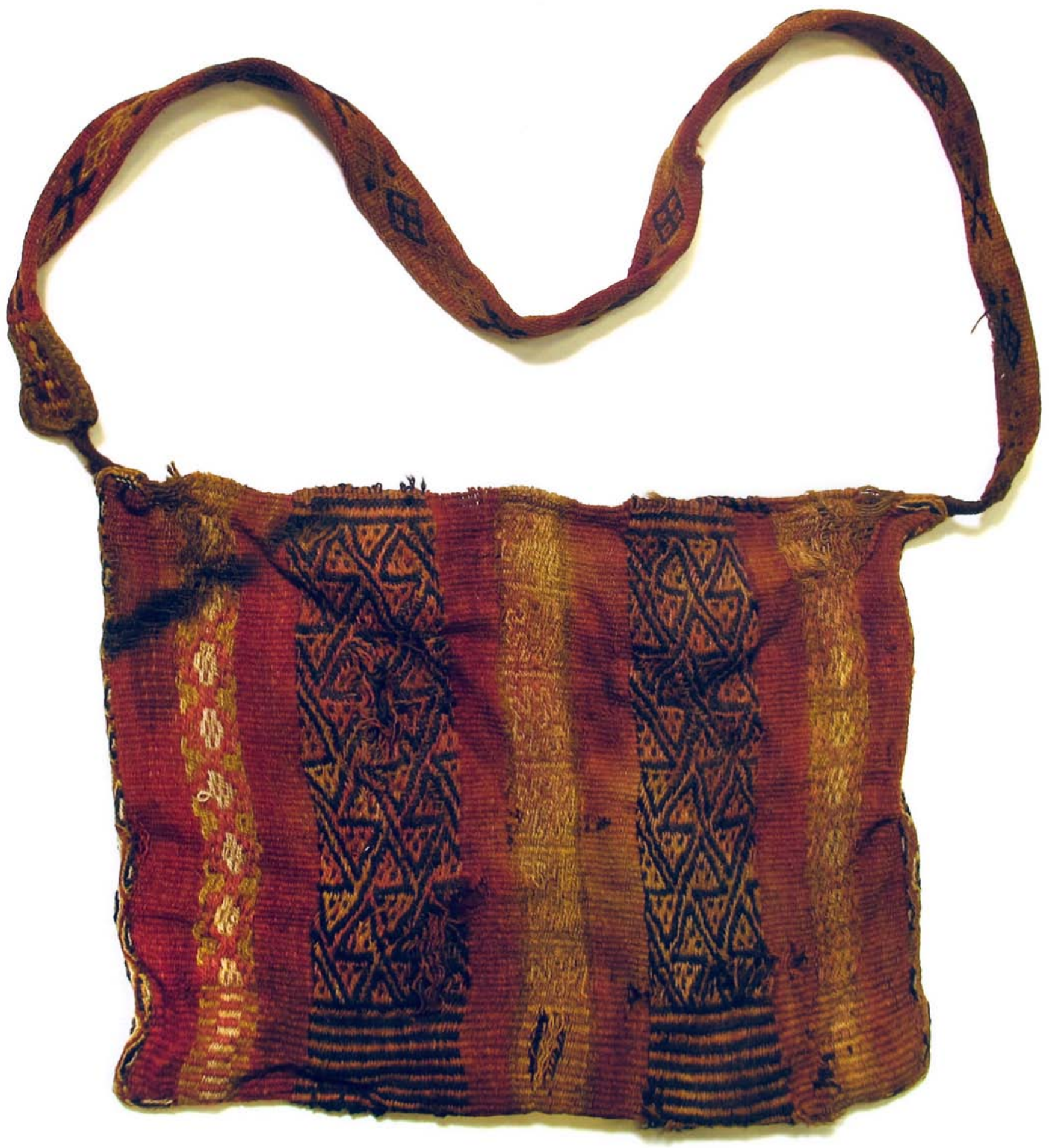

\section{Museum number: V $\mathbf{9 . 3 3 3}$}

Item: Bag

Style: Central coast, Inka

Size: bag, $20 \times 27 \mathrm{~cm}$; strap, $67 \times 2 \mathrm{~cm}$

Material/technique: Bag and strap are in camelid fiber $2 \mathrm{~S}$. Both have complementary warp patterns. The strap (double woven,

complementary warp weave) is set up tubular, and the edges woven tubular. The bag has stem stitch embroidery along the sides.

The threadcount of the bag and strap (in plain weave) is $30 \times 5$ per $\mathrm{cm}$

Bag has 4 selvedges and warp-selvedge at top.

The bag is complete. 


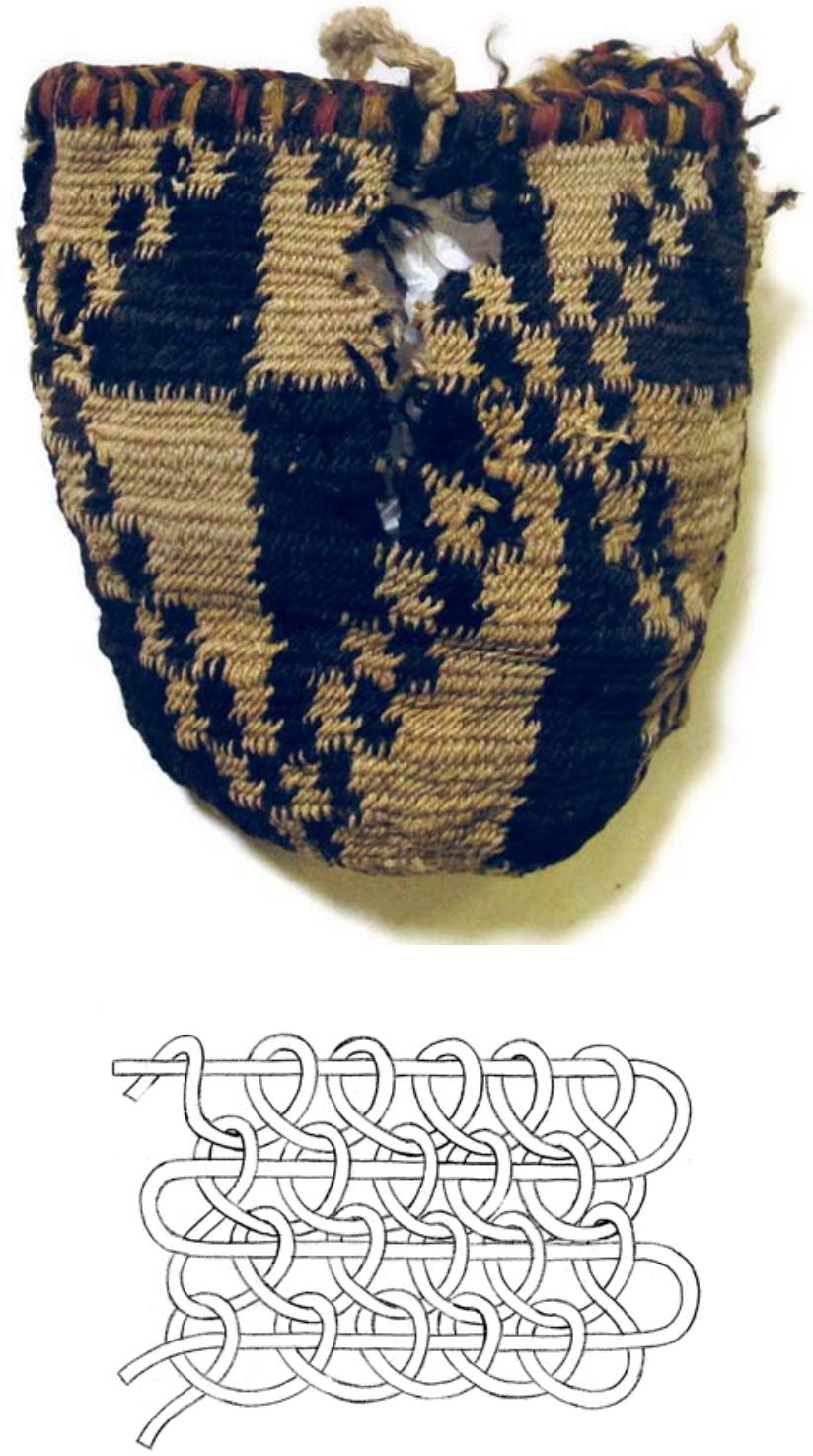

\section{Museum number: V 9.336}

Item: Bag

Style: Inka

Size: $11 \times 12 \mathrm{~cm}$

Material/technique: Spiral simple looping with extra acompanying yarn in camelid fiber $2 \mathrm{~S}$. The light and the dark yarns are alternatively hidden in the other. The upper edge is embroidered with cross knit looping stitches.

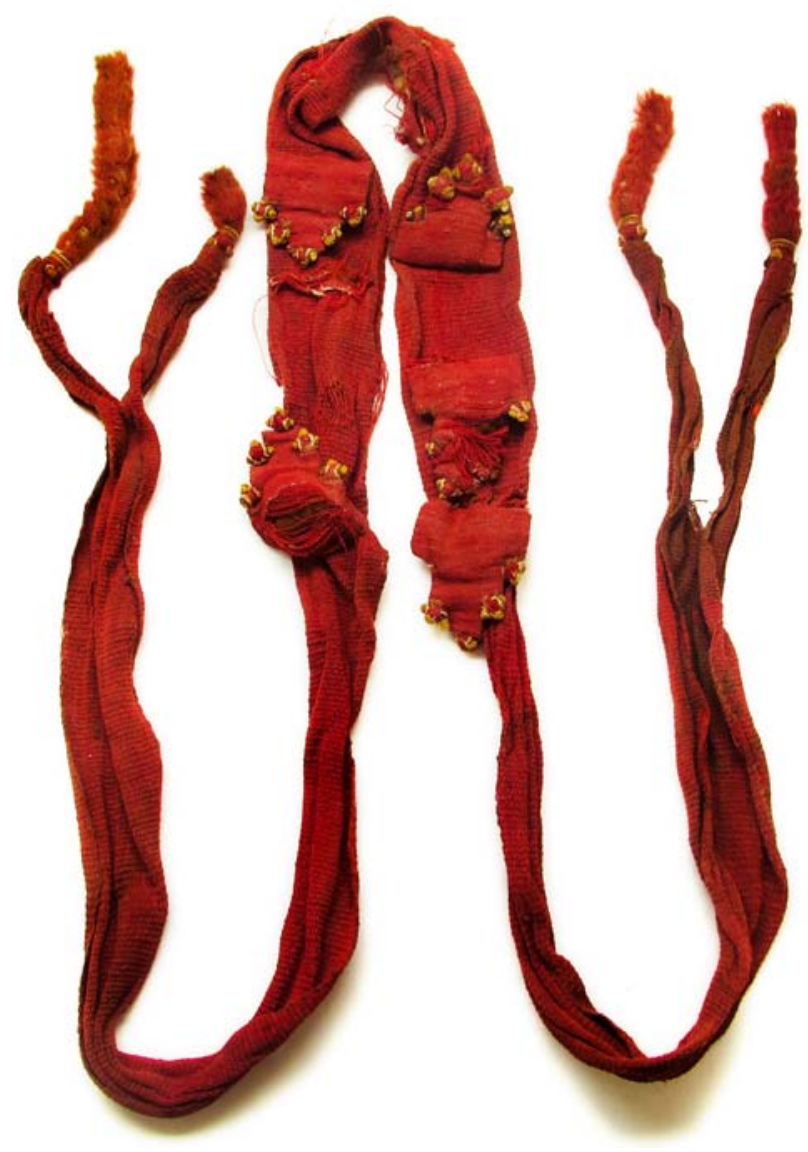

\section{Museum number: V 9.340}

Item: Hairband

Style: North/Central coast

Size: $200 \times 8 \mathrm{~cm}$

Material/technique: Band (warp camelid fiber 2S, weft cotton

S). In the center part the band is decorated with little woven bags/pillows filled with unspun cotton fibers. The pillows are embroidered with 5 pointed tops.

At both ends are $11 \mathrm{~cm}$ tassel arranged on top of each other. 

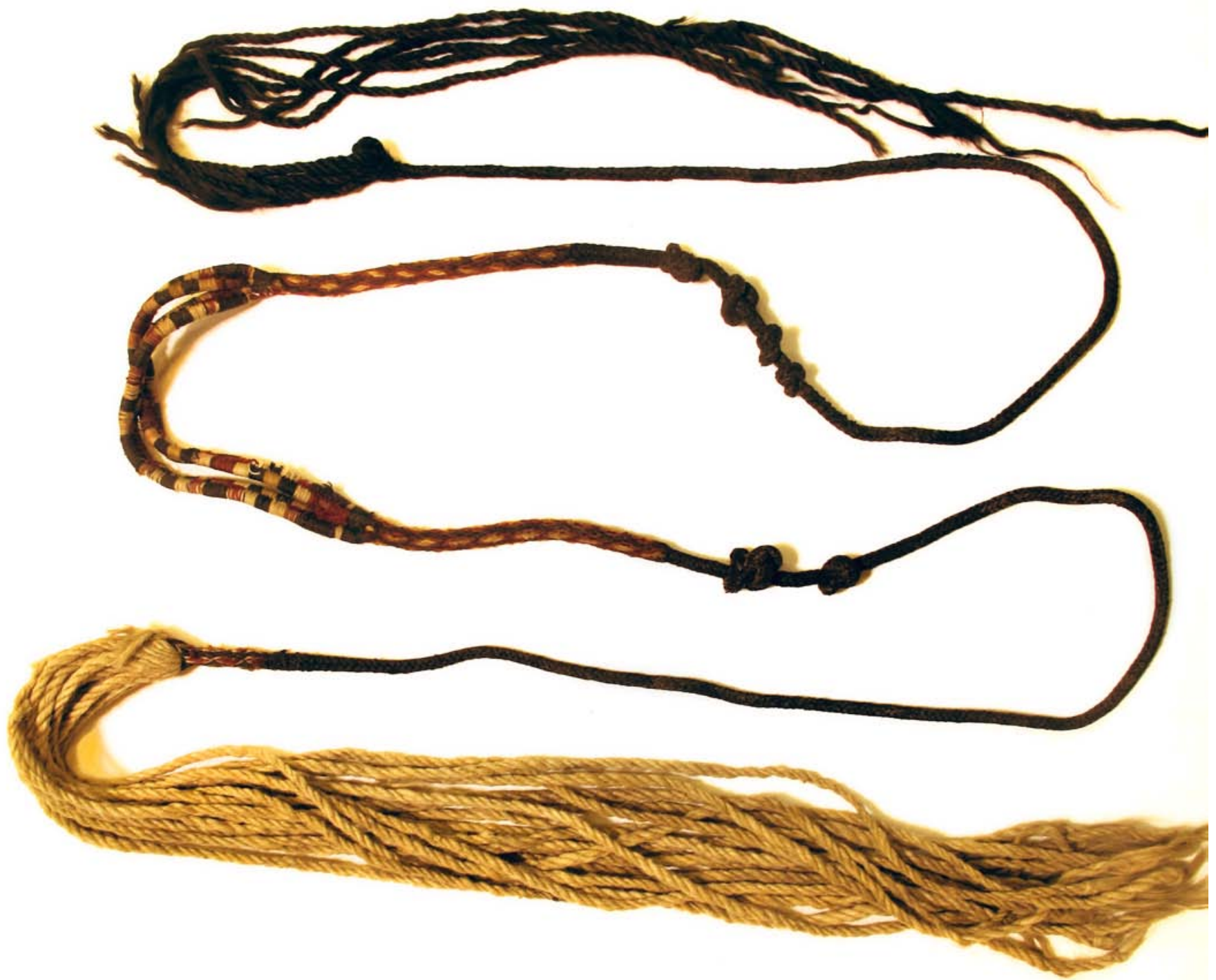

\section{Museum number: V 9.343}

Item: Sling (complete)

Style: Central/North coast, Late Horizon.

Size: $335 \mathrm{~cm}$

Material/technique:

1. The sling has at boths ends a $60-67 \mathrm{~cm}$ tassel in camelid fiber $2 \mathrm{~S}$.

2. Following the white tassel is a round fistbraid of $4 \mathrm{~cm}$.

3. Then follows a square braid of 8 strands $(68 \mathrm{~cm})$. At the end it has 2 knots - a single knot and a complicated (not kipu like).

4. Then follows a $14 \mathrm{~cm}$ round fistbraid.

5. The cradle is 4 bundles wrapped with a slit in the middle.

$6.14 \mathrm{~cm}$ round fistbraid.

$7.66 \mathrm{~cm}$ square braid of 8 strands - with at the beginning 4 knots (two single and two complicated).

The sling ends in a $66 \mathrm{~cm}$ long tassel.

All is camelid fiber $2 \mathrm{~S}$. 

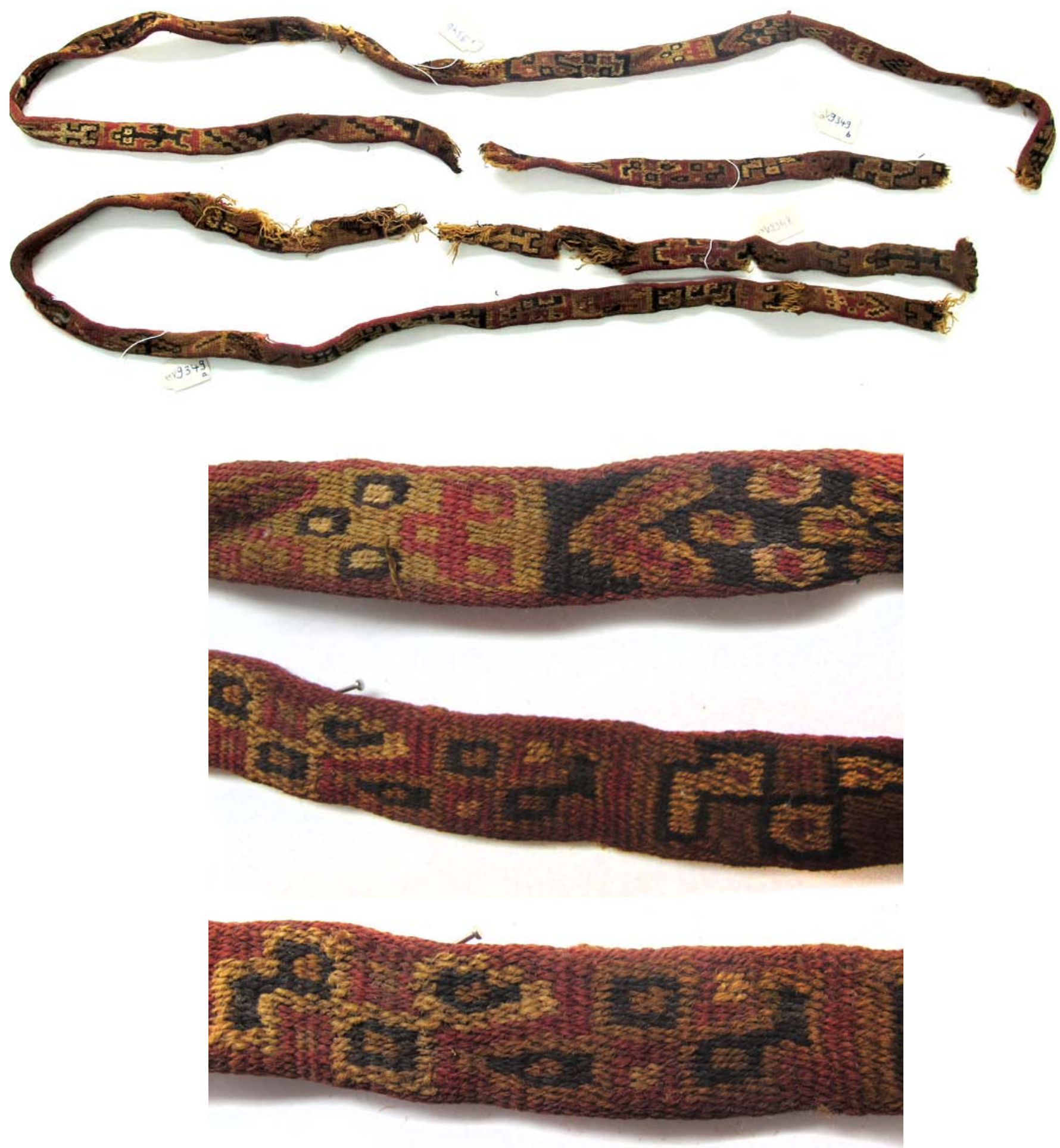

\section{Museum number: V 9.346,}

\section{9.348, V 9.349}

Item: Tubular band

Style: Central Coast, Late Horizon

Size: V 9.346: 83 cm, V 9.348: 27 cm, V 9.349 a: $68 \mathrm{~cm}$, V 9.349 b: $22 \mathrm{~cm}$. All 1,5 wide.

Material/technique: Camelid fiber $2 S$ yarns woven in tubular complimentary warp weave. The threadcount is $7 \times 14$ per $\mathrm{cm}$. 


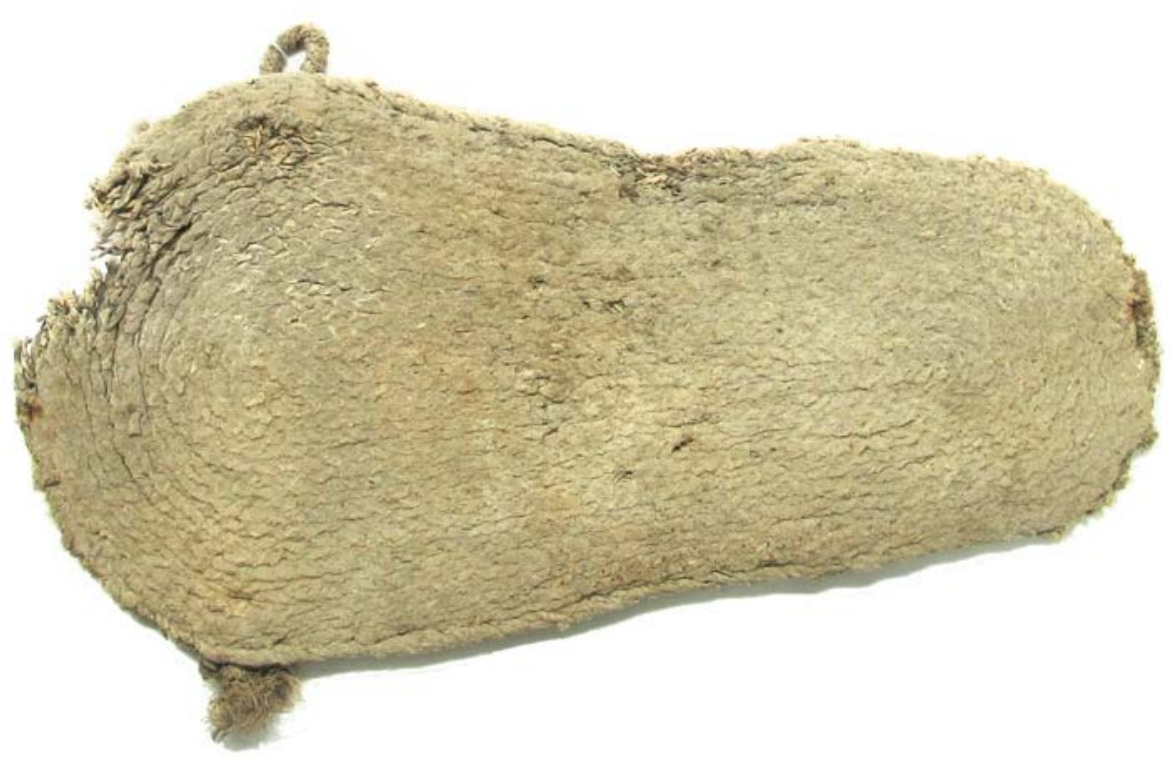

Museum number: V $\mathbf{9 . 3 3 0}$

Item: Shoesole

Style: Inka/ Central/North coast?

Size: $21 \times 23 \mathrm{~cm}$

Material/technique: cotton $2 Z$, multiple paired yarns. The sole is stitched together from braids that are braided from 3 strands.

\section{Museum number: V 9.337}

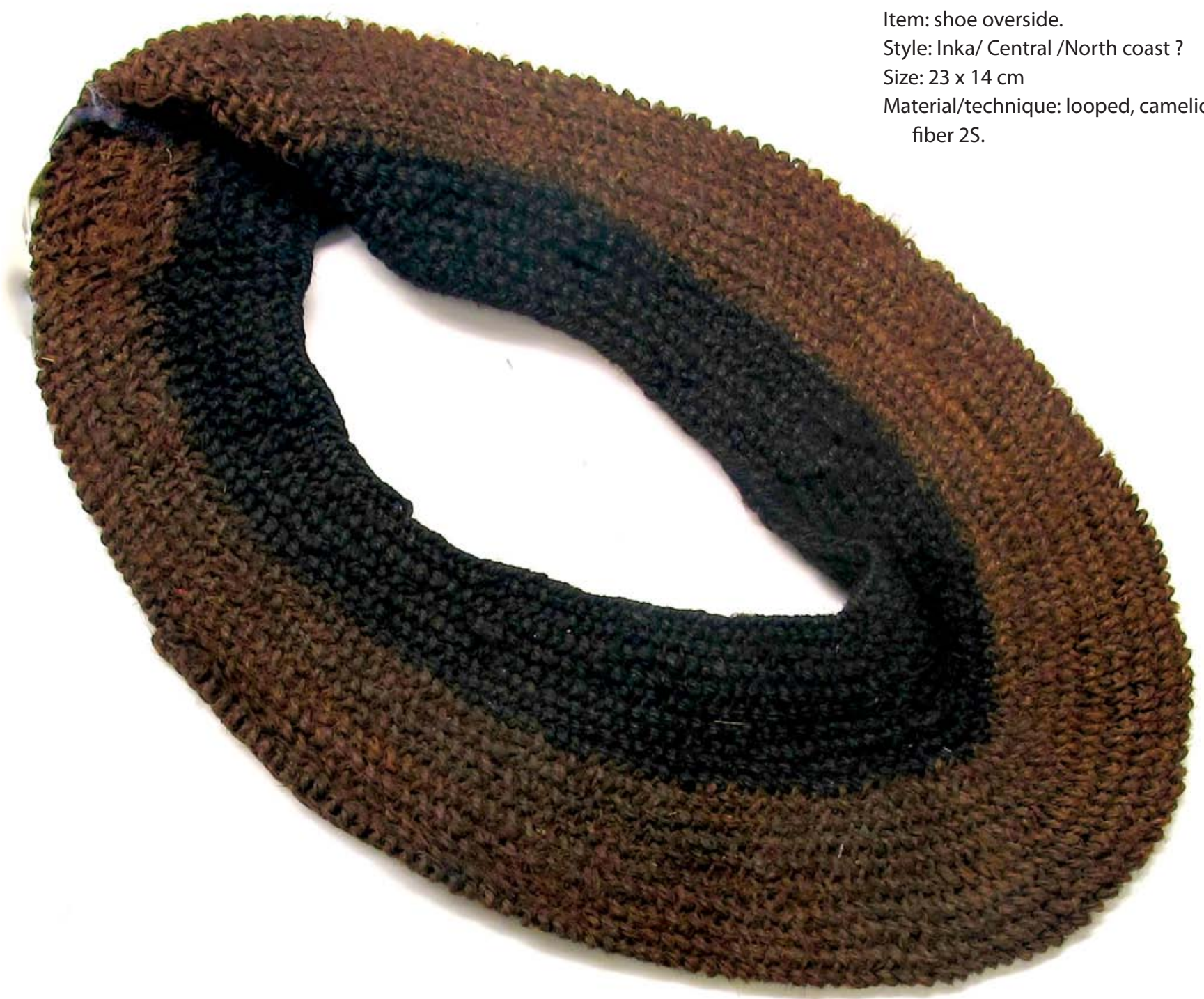




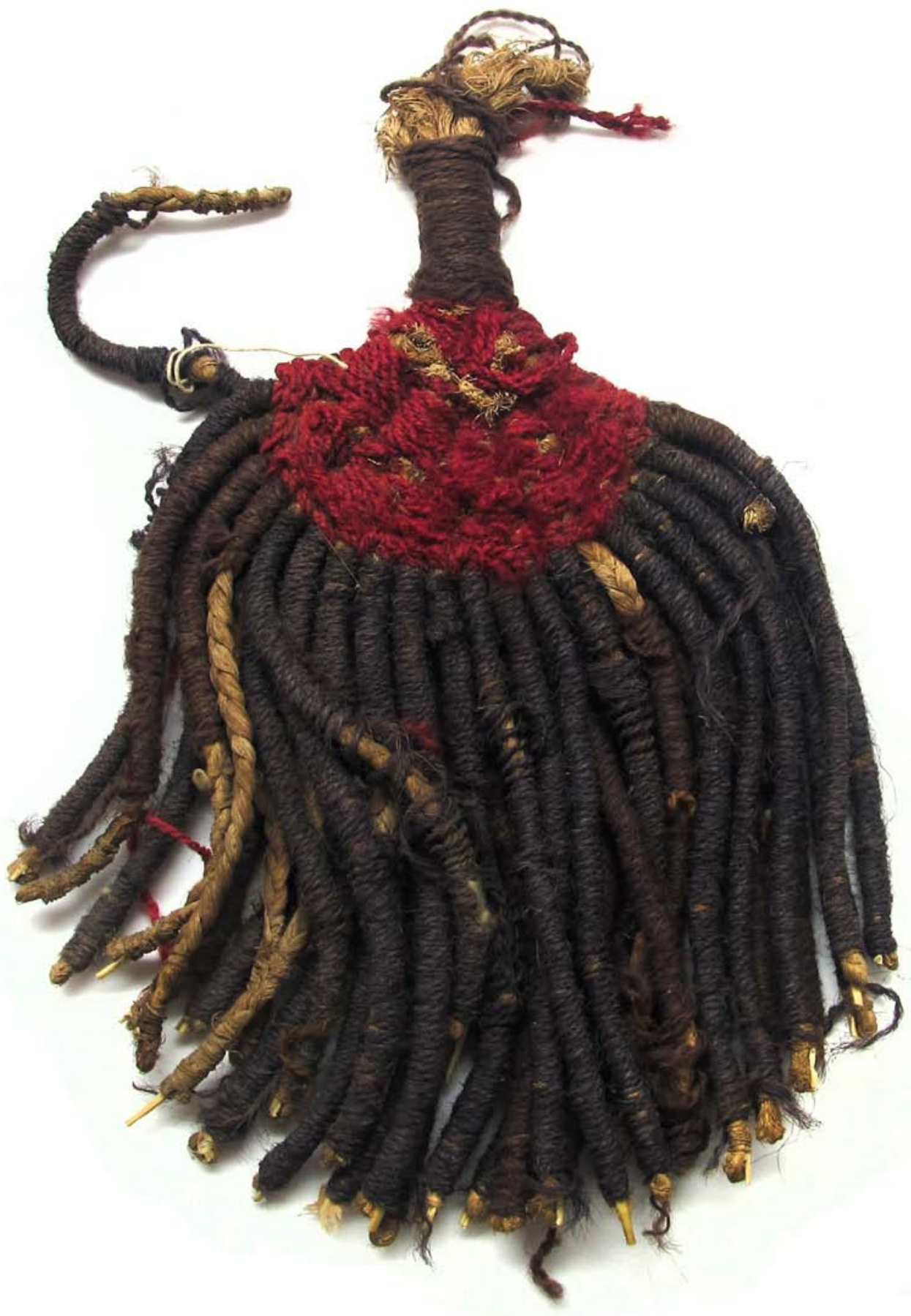

\section{Museum number: VoNr 1829}

Item: Tassel

Style: ?

Size: $18 \times 13 \mathrm{~cm}$

Material/technique: 3-braided plantfiber strings wrapped with 25 camelid fiber yarns. 


\section{COLONIAL 1600- 1700 AD}

\section{Museum number: V 9.000}

Item: Complete textile.

Style: Colonial 16-1700 AD Size: $76 \times 61 \mathrm{~cm}$

Material/technique:

The textile is woven in interlocked tapestry with a warp in cotton $2 S$ and a weft in camelid fiber $2 \mathrm{~S}$. The threadcount is $10 \mathrm{x}$ 40-50 per $\mathrm{cm}$.

Figures: pampas hare, birds, fish, puma, lizard, and symbolic animals: mermaid, fat scorpion.

The other half of the textile is in Textile Museum, Washington.

Published in: Helena Phipps, Johanna Hecht, Cristina Esteras Martín, The Colonial Andes: Tapestries and Silverwork, 1530-1830, Metropolitan Museum of Art Series, p. , 2004.

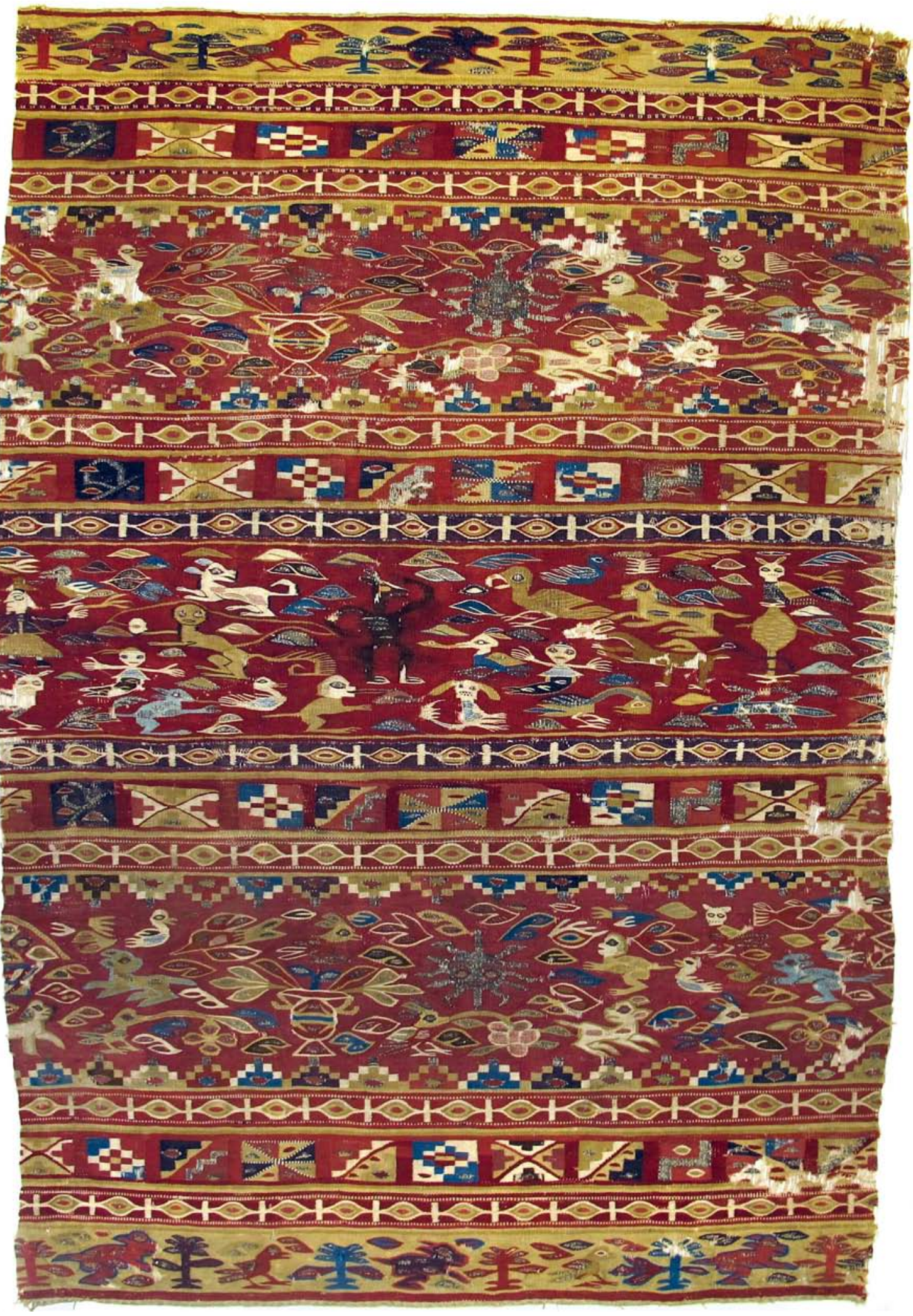




\section{RECENT 1800-2000 AD}

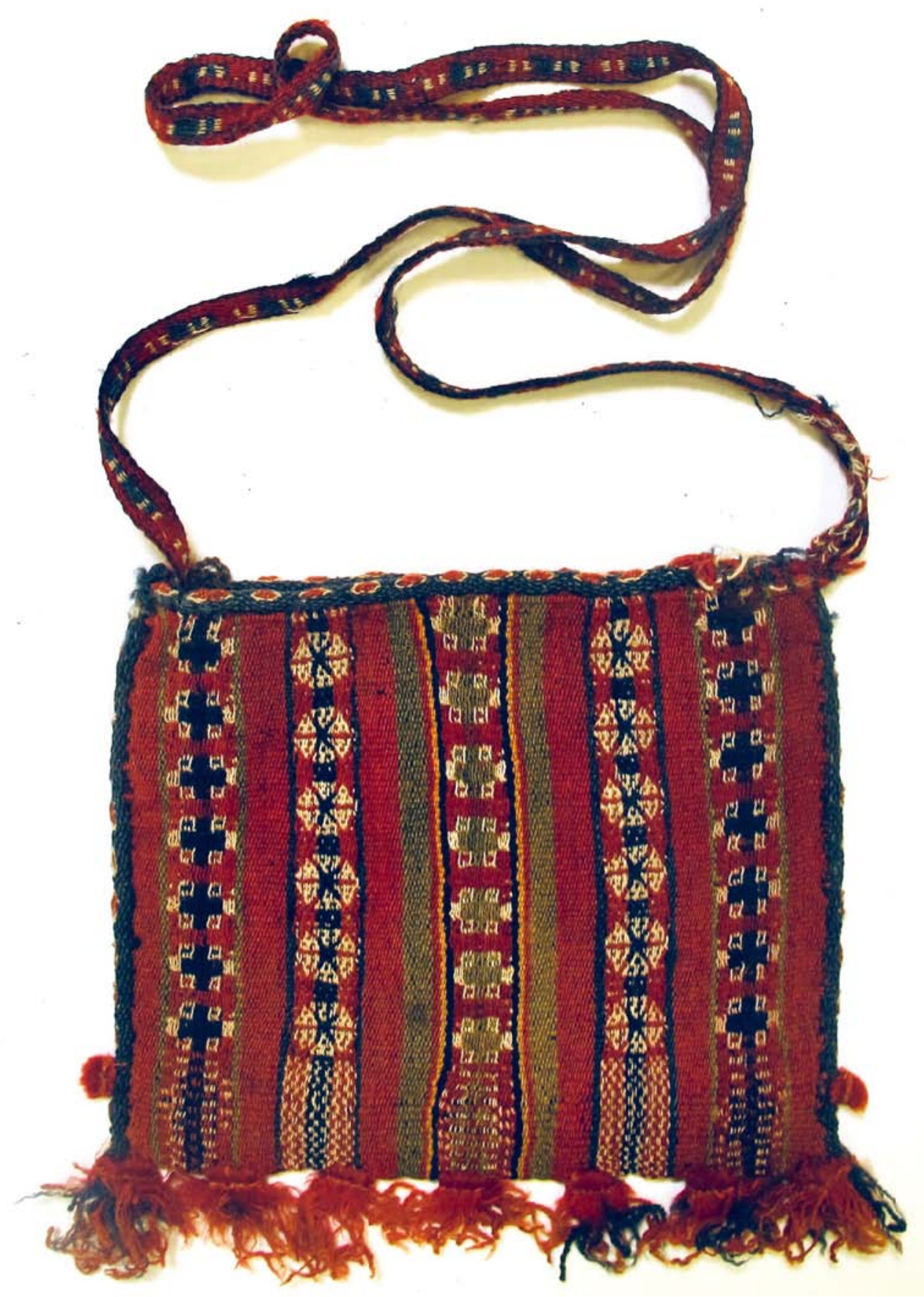

\section{Museum number: V 3.168}

Item: Bag for coca (coca inside)

Style: Colonial - mid 20. century.

Size: $19 \times 20 \mathrm{~cm}$ - and strap $100 \times 1 \mathrm{~cm}$

Material/technique: Camelid fiber $2 \mathrm{~S}$.

Bag and strap are woven in complementary warp weave.

The edges of the bag has woven tube warp edgings at the sides and top opening.

An acrylic pink sewing thread is attaching the strap to the bag at one side. 


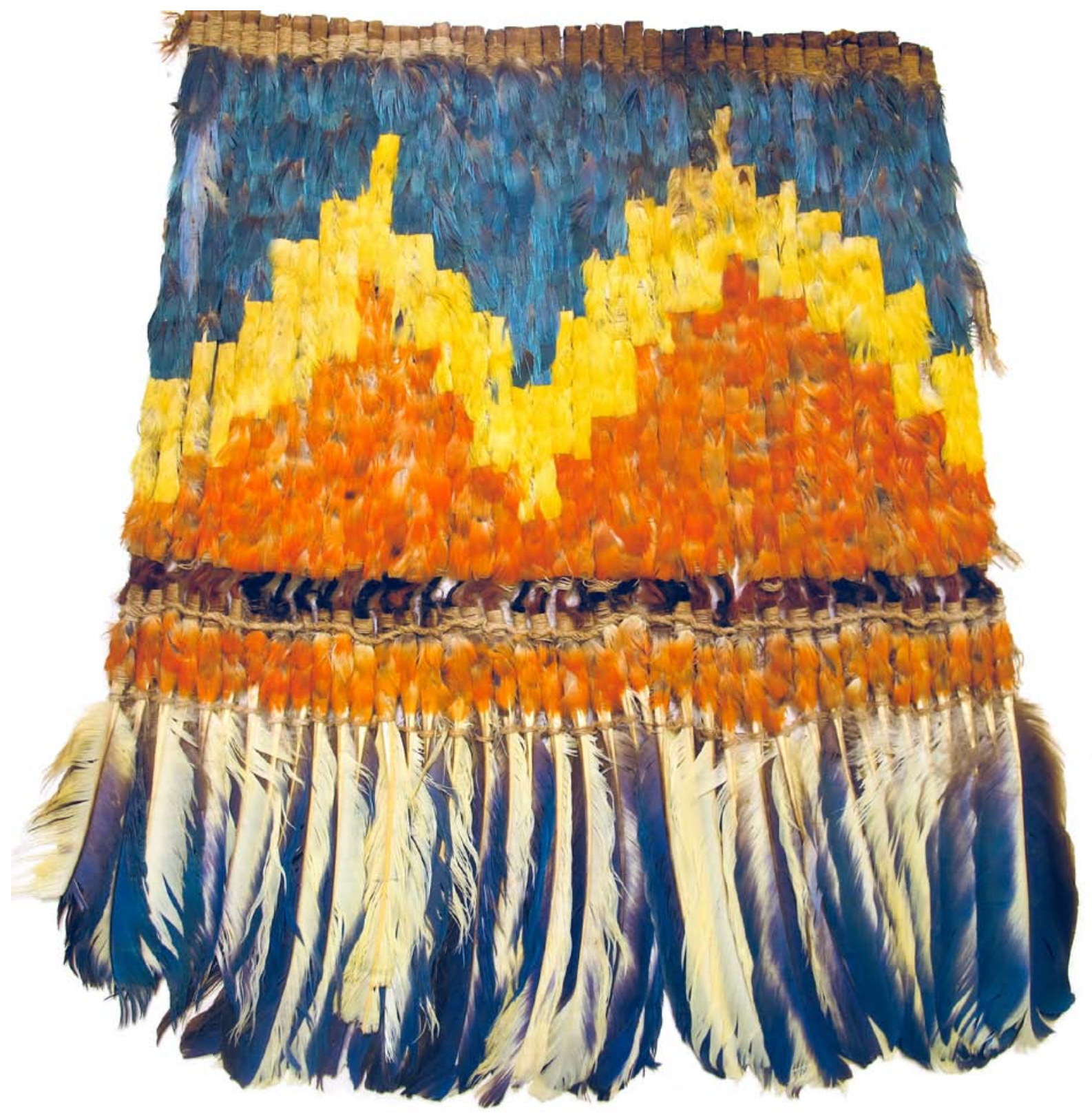

\section{Museum number: V 10.399 b}

Item: Feather apron?

Culture: 19-20th Century, from Amazonia

Size: 41 x $40 \mathrm{~cm}$

Material/technique: Split cane sticks $(0,5 \mathrm{~cm})$ are wrapped with 25 cotton yarns. Feathers are secured in these wrappings.

At bottom a row of larger $(17 \mathrm{~cm})$ feathers.

Gift by the Museum Society on the occasion of the 150th anniversary of the Roemer-Museum, 1996

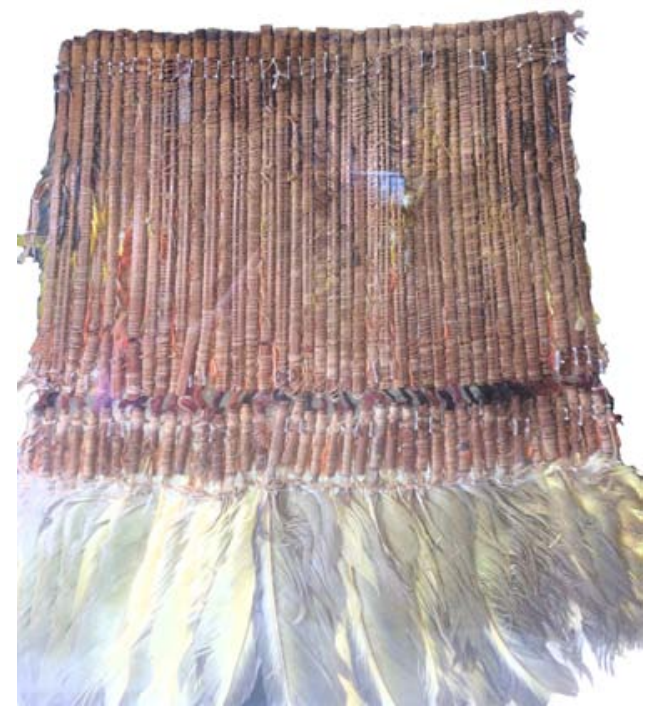




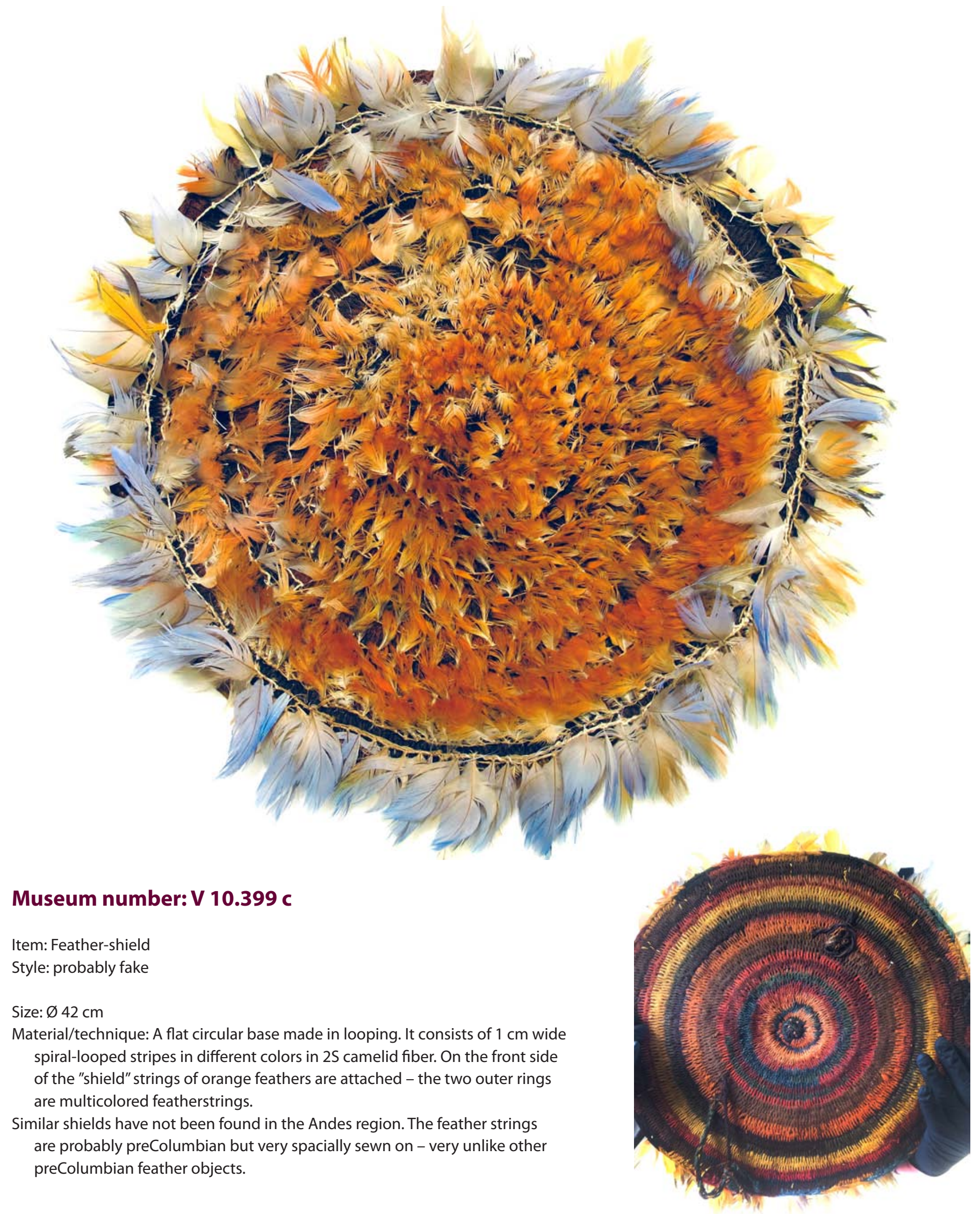


Museum number: V 9.322

Item: False mummy head Style:? Maybe a

falsification???

Size: $83 \times 30 \mathrm{~cm}$

Material/technique: Maybe a "False mummy head" to attach on top of a mummy? It is made from plain weave cotton ( $\mathrm{S}$ for warp, paired $\mathrm{S}$ for wefts). The threadcount is $12 \mathrm{x}$ 5 per $\mathrm{cm}$, stuffed with plant material. Plantfiber is attached as a wig. A long $180 \times 8 \mathrm{~cm}$, cotton $2 S$ belt (with a threadcount of $20 \times 3 \mathrm{~cm}$ ) is tied on to the head with half of a fistbraided plantfiber sling and loose camelid fiber yarns. The belt has at either end a $10 \mathrm{~cm}$ long tapestry with $2 \mathrm{~S}$ camelid fiber wefts.

At the back of the head is a $25 \times 25 \mathrm{~cm} 4$ selvedged cotton $\mathrm{S}$ textile made in plain weave. The threadcount of this textile is $12 \times 12$ per $\mathrm{cm}$.

The materials are preColumbian, but usually the "false mummy heads" were closed pillows to set on top of a fardel. The long, loose textile seems odd...?

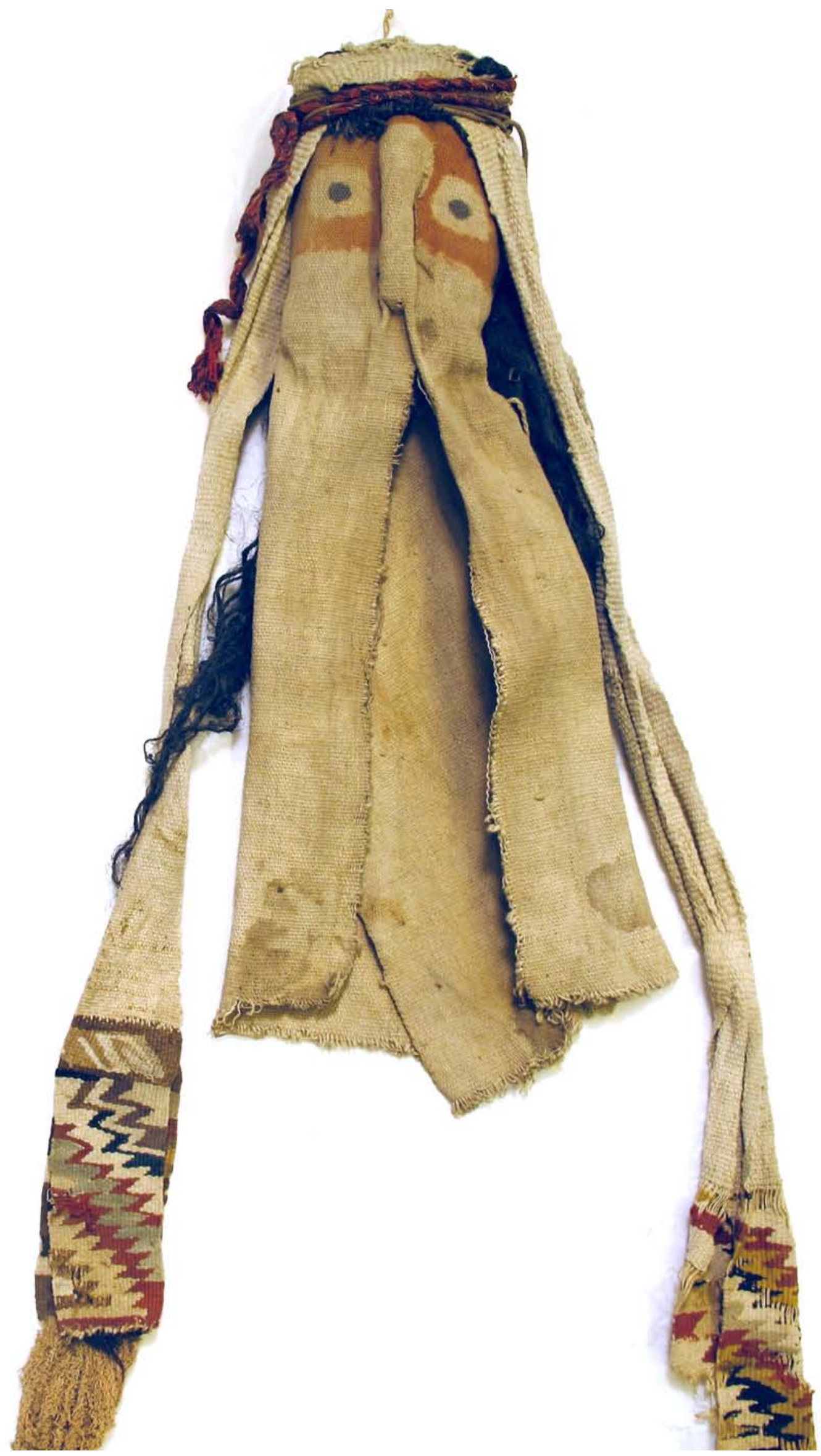


